Portland State University

PDXScholar

8-10-2006

\title{
The fisheries of the Lower Columbia River, 1792 to 1850, based on EuroAmerican explorer and fur company accounts
}

Michael A. Martin

Portland State University

Follow this and additional works at: https://pdxscholar.library.pdx.edu/open_access_etds

Part of the Anthropology Commons

Let us know how access to this document benefits you.

Recommended Citation

Martin, Michael A., "The fisheries of the Lower Columbia River, 1792 to 1850, based on EuroAmerican explorer and fur company accounts" (2006). Dissertations and Theses. Paper 2851.

https://doi.org/10.15760/etd.2846

This Thesis is brought to you for free and open access. It has been accepted for inclusion in Dissertations and Theses by an authorized administrator of PDXScholar. Please contact us if we can make this document more accessible: pdxscholar@pdx.edu. 


\section{THESIS APPROVAL}

The abstract and thesis of Michael A. Martin for Master of Arts in Anthropology were presented August 10, 2006, and accepted by the thesis committee and department.

COMMITTEE APPROVALS:

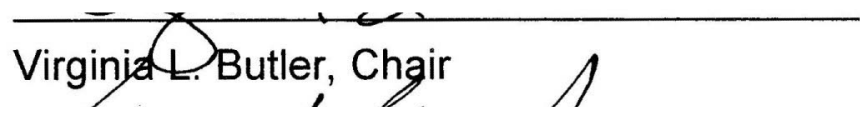

Kenneth M. Ames

Katrine Barber

Representative of the Offjee of Graduate Studies

DEPARTMENT APPROVAL:

Kenneth M. Ames, Chair

Department of Anthropology 


\section{ABSTRACT}

An abstract of the thesis of Michael A. Martin for the Master of Arts in Anthropology presented August 10, 2006.

Title: The Fisheries of the Lower Columbia River, 1792 to 1850 , based on EuroAmerican Explorer and Fur Company Accounts.

The role of fish in the Native American economy of the lower Columbia River has never been considered in detail. My study focused on the Columbia River from its mouth to the Cascades and the Willamette River from its confluence with the Columbia to Willamette Falls. For this study I asked: How was salmon used? What other fish were important? Where and how were these fish taken and used?

To address these questions, I evaluated historical documents, including explorer's accounts and the administrative records of fur companies dating from the late 1700's through the 1850's. I used fishery data, physical descriptions, migratory and spawning habits, and foraging patterns to identify fish in historic accounts. I annotated historic information and provided a synthesis of the historic fisheries.

White sturgeon (Acipenser transmontanus), eulachon (Thaleichthys pacificus) and chinook salmon (Oncorhynchus tshawytscha) dominated the trade. Chum (O.keta) and lamprey (Lampetra sp.) were available, although not traded in large numbers. White sturgeon, eulachon, fall chinook, chum 
and lamprey were smoke cured.

Steelhead (O.mykiss), coho (O.kisutch), perch (Embiotocidae), and resident trout were traded in small numbers indicating that other fish were part of the economy. Sockeye salmon (O.nerka) was not traded.

Indians captured white sturgeon with: multiple hooks on set-lines and funnel nets to take white sturgeon during the winter; scoop nets and the eulachon rake took eulachon; spring and summer chinook were taken with hoop nets and platforms in the Cascades rapids and at Willamette Falls; gaffs were used to take chinook and sturgeon during the summer in Baker Bay; and hoop nets took fall chinook in streams. Seine nets were noted but not were not discussed except for the chinook fishery of Baker Bay.

Historic information on fishes used and methods of capture contrasts with the archaeological record of the Portland Basin. Resident freshwater fish, minnows (Cyprinidae) and suckers (Catostomus sp.), are abundant in the archaeological faunal record, but are rarely mentioned in historic accounts. Artifacts such as net weights are common in archaeological contexts in contrast with the limited discussions in the historic record. Possible explanations for these discrepancies are reviewed. 
'THE FISHERIES OF THE LOWER COLUMBIA RIVER, 1792 TO 1850, BASED ON EUROAMERICAN EXPLORER AND FUR COMPANY ACCOUNTS'

by

MICHAEL A. MARTIN

A thesis submitted in partial fulfillment of the requirements for the degree of

MASTER OF ARTS

in

ANTHROPOLOGY

Portland State University

2006 


\section{DEDICATION}

To my father, Earl Martin, who I wished could have been around to see the final copy. He was a source of inspiration.

And to my son, Nathan. I think its time for us to go fishing, thanks for waiting, get baited up. 


\section{ACKNOWLEDGMENTS}

Thanks to my thesis advisor, Dr. Virginia Butler. Virginia, thanks for your tenacity, determination and vision. I appreciate how much you saw in my thesis and the effort you made to get me there.

To my step-mother, Deanna Martin, thanks for the last edits!

To my friends who have waited patiently and questioned my sanity.

To my wife, Gwen and my son Nathan, thanks for your many readings of the drafts, drawings and support. 


\section{TABLE OF CONTENTS}

PAGE

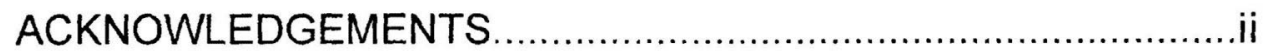

List of Tables........................................................................... iv

List of Figures............................................................................

CHAPTER

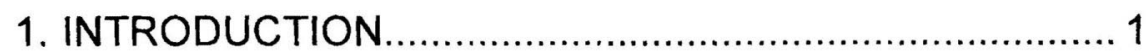

2. THE FISH RESOURCE BASE OF THE LOWER

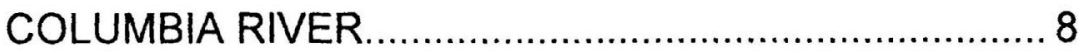

3. AN ANNOTATED ACCOUNT OF THE HISTORIC FISHERIES OF THE LOWER COLUMBIA RIVER 1792 TO 1850

4. THE FISH TRADE AND FISHERIES '............................144

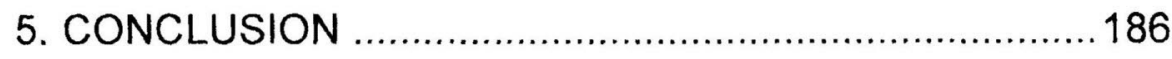

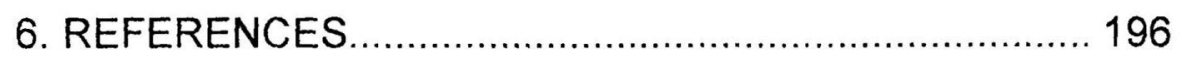




\section{LIST OF TABLES}

2-1 Spring and Summer Chinook Spawning Tributaries between Bonneville and the mouth of the Columbia River....42

2-2 Fall Chinook Spawning Tributaries between Bonneville and the mouth of the Columbia River.

2-3 Coho: Spawning Tributaries between Bonneville and the mouth of the Columbia River.

2-4 Chum: Spawning Tributaries between Bonneville and the mouth of the Columbia River.

2-5 Steelhead: Spawning Tributaries between

Bonneville and the mouth of the Columbia River.

2-6 Periods of aggregation of resident and migratory fish.

3-1 Lewis and Clark: Fish

3-2 Lewis and Clark: Fisheries

3-3 Lewis and Clark: Fishing Gear.

3-4 McDougall: Fish

3-5 McDougall: Fisheries.

3-6 McDougall: Fishing Gear.

3-7 Franchere: Fish.

3-8 Franchere: Fisheries

3-9 Franchere: Fishing Gear.

3-10 Stuart: Fish.

3-11 Stuart: Fishing Gear.

3-12 Stuart: Fisheries 
3-14 Henry: Fisheries................................................ 126

3-15 Henry: Fishing Gear.......................................... 127

3-16 Douglas: Fish.................................................. 128

3-17 Townsend: Fish.................................................. 129

3-18 Townsend: Fisheries..............................................130

3-19 Townsend: Fishing Gear........................................131

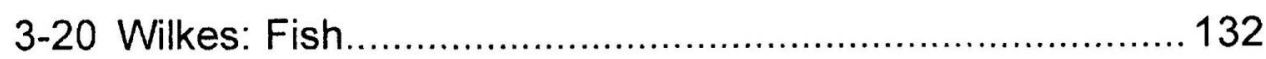

3-21 Wilkes: Fisheries................................................... 133

3-22 Wilkes: Fishing Gear............................................. 134

3-23 Swan: Fish.......................................................... 135

3-24 Swan: Fisheries..................................................... 136

3-25 Swan: Fishing Gear............................................... 137

4-1 Fish Resources of the Study Area as Reported from

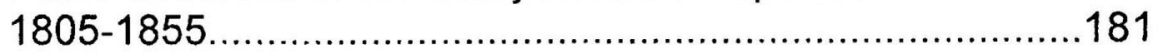

4-2 Monthly Timing of Small Trades of Fish or Small Quantities Fresh Fish................................................. 182

4-3 Fish Providing Preserved Stores................................. 183 


\section{LIST OF FIGURES}

1-1 Lower Columbia River Study Area..................................... 7

2-1 Eulachon Spawning Areas............................................. 48

3-1 Acute Angle Hook......................................................138

3-2 McDougall's Sturgeon Trade 1812-1813......................139

3-3 McDougall's Fresh Salmon Trade 1812-1813.................. 140

3-4 McDougall's Trade in Fresh, Dried and Smoke Salmon......141

3-5 Set line, artistic intrepretation (H. Franchere 1967:112) .... 142

3-6 Cascades Fishing Platform, artistic intrepretation.............143 (from Stuart (Rollins 1935)

4-1 Timing of Bulk Fisheries \& Products................................ 184

4-2 So-called Net Weights of the Portland Basin .................... 185 


\section{CHAPTER 1}

\section{INTRODUCTION}

Fish are a fundamental part of the economy of the Northwest Coast (Suttles 1990:16). The wide spread use of fish is reported in synthetic overviews of the Pacific Northwest (Mitchell and Donald 1988; Matson 1992; Matson \& Coupland 1995; Ames and Maschner 1999). While the emphasis is on the common resources of the region, with salmon dominating the discussion, it is recognized that placement of a local economy into a regional one is dependent on understanding which resources were used locally (Ames and Maschner 1999:32).

In regional terms, the lower Columbia is considered a salmon economy (Drucker 1963: Schalk 1977; Matson 1992) even when the discussion turns to local resource use (Pettigrew 1990; Krauss 1990). When salmon is considered in local terms it is not a single resource but a resource of species and in some cases stocks of species each with its own variability in time, space and economic importance. The Columbia River, for example, is home to at least six species of salmon and trout (including the reclassified steelhead) with distinctive sub-populations or stocks (Fulton 1968; Monaco et al. 1990). How the different species of salmon that inhabit the Columbia River were used has not been addressed in regional archaeology.

Acknowledging potential variation in use of salmon raises the question of the potential economic value of other local fish resources. Suttles (1968:60) characterized the problem as recognizing the variables affecting resource availability with the goal to "state fairly accurately what the resource base of 
each people's territory were". What other fish were economically important? Which ones were the focus of specialized or intensive use (see Ames and Maschner 1999:117) is undocumented for the lower Columbia because this effort has not been undertaken. Until the pattern of salmon usage is defined and the economic importance of other fish noted, how the historic Columbia River economy fits into the regional economy of the Northwest Coast will not be clear.

How many different fish were used in the study area? The archaeological faunal record for the Portland Basin suggests a very diverse use of fish for some of the prehistoric occupations of the lower Columbia River. As many as 10 different species of fish ranging in size from minnows to sturgeon have been routinely reported (Saleeby 1983; Butler 1992;1994;1996;1998; 2000b; 2001).

Identifying local resources includes identifying the gear used to take the fish, a research question of long standing in Northwest Coast anthropology. The basic question is to understand the "relative effectiveness of the different techniques [used to take a range of resources] under similar conditions and the same technique under different conditions" (Suttles 1968:63). Recent studies have pointed out the effect of gear on acquiring resources. For example, Grayson and Cannon (1999:146) suggest that the value or contribution of a "resource is not intrinsic to the resource itself, but results from the interaction of resource, technology, and application of that technology".

Gear can be modified in form to enhance and expand resource opportunities. Kew (1992) has pointed out that seine net fishing gear used in 
much of the Fraser River developed from types first used in the estuary. Romanoff (1992) specifically suggested that seine nets used in the lower river were reconfigured as pole suspended seines which allowed fishing in the narrow bedrock canyons of the middle Fraser River.

Gear can be configured to take particular fish. Allen (1994) suggests that Polynesians configured fish hooks to take fish with particular sized mouths which in turn is evidence of the exploitation of different habitats because some fish are specialized feeders limiting their foraging to particular places. Similarly, Croes (1997) has noted the stylistic and functional aspects of fish hook forms used in the Northwest Coast cultural area. He believes that certain types of hooks were used to take halibut and cod. These hooks are present in different cultural periods and with their modifications are evidence of these fisheries. These remarks suggest that an important problem is identification of specialized gear that may be used to take particular fish, perhaps adapted to particular settings, or to take fish of a certain body size.

Using gear implies understanding fish foraging, feeding and migration behaviors. Monks (1987) suggested that fisheries might have a complexity not apparent if one assumed that one species dominated the economy. He identified a special situation where one group of Northwest foragers may have taken advantage of salmon and waterfowl preying upon herring. Sea mammals may also have been taken as they preyed on both herring and salmon. Monks reported the presence of salmon, herring, water fowl and sea mammal faunal remains associated with a large boulder fish trap and suggested that herring were directed to a relatively small enclosure where they, as well as their predators, salmon, water fowl and sea mammals, could 
be taken. He suggested that knowledge of predator-prey linkages, especially predator feeding and pursuit behaviors, contributed to maximizing resource production.

My thesis is a study of the Native American use of fish resources from 1792 to the 1850's on the lower Columbia River using information found in the historic record. My primary source of information is the ethnohistoric record of the study area; the journals and accounts of explorers, fur traders and settlers. Most of these records include remarks on the trade with Indians for subsistence and others on the lifeways of the Indians. I critically review these records gathering data relevant to the historic fishery of the lower Columbia River and use the description and comments to address these questions: How were the various species of salmon used? What other fish besides salmon were chosen as resources? Given the fish used as resources: Where were they taken? When were the various fisheries initiated? What gear was used to take them? Is there evidence of specialized gear used to particular fish? How productive were the fisheries? And how were these fish, as resources, incorporated into the economy?

In my analysis and synthesis I attempt to provide specific answers to these questions because my overall effort is directed at identifying local resource use. The historic accounts I use are not, however, always clear and therefore some of my answers while plausible, are tentative.

The study area (Figure 1-1) extends from the Columbia River estuary upstream to Bonneville Dam, and a portion of the Willamette River, from its confluence with the Columbia to Willamette Falls. This area includes free flowing reaches, sloughs and overflow lakes of tidally influenced portions of 
the Columbia River, confluences of major tributaries of the Coastal Range and the western slopes of the Cascades.

The results of my thesis will contribute to understanding the economy of the lower Columbia River. The information I provide on specific resource use and procurement strategies may be useful for theoretical research models such as, optimal forging theory, evolutionary archaeology and ecology (see Winterhalder 1981; Bettinger 1991; Lyman and O'Brien 1998; Broughton and O'Connell 1999). These models examine cultural processes in terms of specific prey, body size, and different rates of return as affected by the use of different gear. Identifying as much detail on the specifics of the historic economy may help clarify details of the archaeological economy for these models.

In chapter 2, I discuss the fish reported in ethnohistoric sources and recovered in archaeological excavations. I use fishery research data to define the distribution, habitat preferences and activities of fish that may influence and favor human fisheries. To define their resource value I note the average weight, length and range of these fish. I consider seasonal migrations to spawning locations, typical spawning locations and feeding strategies because these factors identify periods of aggregation when even the smallest fish may provide a substantial return. Following Monks (1987), I note evidence of predation patterns of primary taxa to determine if certain fish co-occur as predator and prey, increasing the quantity of resources that could be taken over a limited period of time.

In chapter 3, I review the historic record of the study area for information on the use of fish resources. To achieve this I abridge, organize and annotate 
information on the fish taken, the gear used, and the places where fisheries were located. As part of this review, I identify the fish to the species and stock level given the information presented. I also comment on gear to clarify descriptions and identify types of gear and possible variants.

In chapter 4,1 focus on the particular use of fish in the study area by considering how the different fisheries operated to take large quantities of fish that were processed for deferred consumption or trade and for fresh consumption. I consider gear from the perspective of how much fish or what scale of return could be expected from the type of gear used. I consider productivity, the scale of return of the fisheries in terms of specific reports on the sizes of various fish and where stated, the numbers of fish taken. I also report qualitative information if the size of fish or counts of the numbers taken are not provided. Finally, I note how specific fish taken as a resource were used, whether they were only consumed as fresh fish or if they were preserved for future use.

In chapter 5, I conclude my thesis by considering the questions I raised, including further work that would contribute to understanding the role of fish and gear in the study area. 

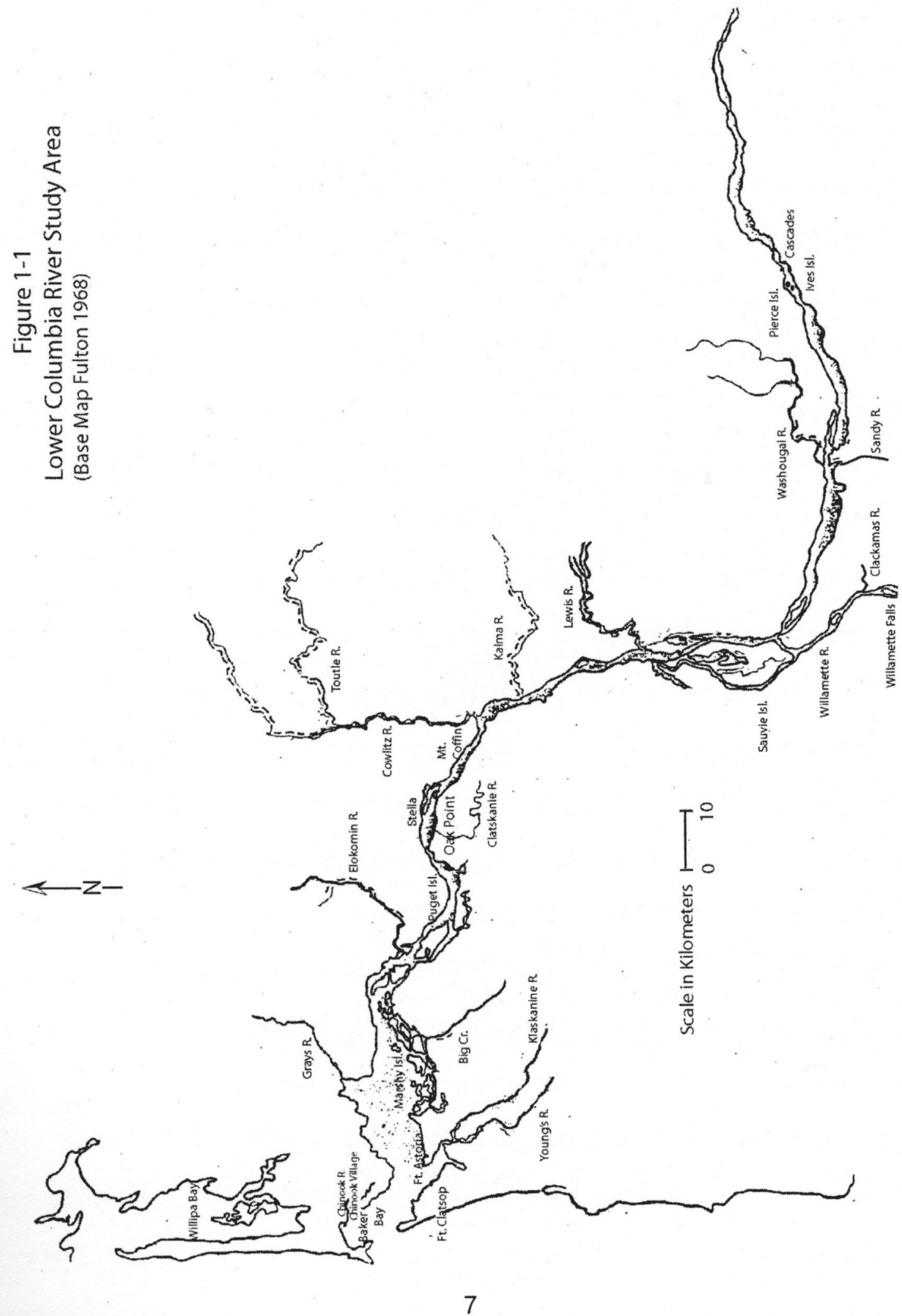


\section{CHAPTER 2}

\section{THE FISH RESOURCE BASE OF THE LOWER COLUMBIA RIVER}

In this chapter I discuss the fish reported in historic and contemporary documents in terms of their distinguishing physical features and their periodic abundance and distribution. Identifying physical characteristics of fish is critical information necessary for determining species. Secondly, defining periods when fish aggregate has important implications for human decision making, affecting which fish to target, where to take them, how to organize labor to take advantage of resources in bulk and which gear to select to maximize returns given the availability of various fish.

The information and data I use is affected by the historical development of the lower Columbia River. Development, including historic and modern logging, pollution from agriculture, urban and industrial sources, the construction of hydroelectric dams, as well as the intensive exploitive fisheries have all reduced fish populations and their habitat. Navigation improvements such as jetties have extended salt water intrusion in the river essentially moving the estuary farther upstream. The information I provide in this chapter contributes insights into the distribution of fish and the fisheries of the late 1700 's through the 1850's. While it is important to note that the early 19th century commercial fishery data on catches suggest something of the magnitude of available fish, the 20th century fisheries data are best used as supportive information because the impacts to fish populations from over fishing and habitat loss have compromised this information. For example, 
some anadromous fish runs have been eliminated and others reduced (Netboy 1980) and for those that remain their abundance and distribution probably does not match 18 th and 19 th century conditions.

The fish that are discussed are either noted in the historic record or recovered in archaeological contexts within the study area. Anadromous fish include: Acipenser medirostris, green sturgeon; A. transmontanus, white sturgeon; Thaleichthys pacificus, eulachon; Clupea harengus, pacific herring and Lampetra tridentata, Pacific lamprey; and some of the species of the genus Oncorhynchus, salmon and trout, including: $O$. tshawytscha, chinook salmon, O. kisutch, coho salmon, O. keta, chum salmon, O. nerka, sockeye salmon, 0 . mykiss, steelhead, derived from the non-anadromous resident rainbow trout and 0 . clarki clarki, cutthroat trout

One family of marine fish, Embiotocidae, includes the surf perch. Surf perch are not discussed at the species level because they are only referenced in one historic account without sufficient detail to document the species.

Resident fish is a broad category that includes: Platichthys stellatus, starry flounder; Acrocheilus alutaceus, chiselmouth; Catostomus macrocheilus, large scale sucker; Mylocheilus caurinus, peamouth chub; Ptychocheilus oregonensis, northern pikeminnow; Percopsis transmontana, sandroller; Rhinichthys osculus, speckled dace; and Gasterosteus aculeatus, threespine stickleback.

My sources of information include fishery data from fishery research reports, fish field guides, and recreational fishing guides. I used these sources to define when the fish of record aggregate, how they are distributed and to identify distinguishing features to help identify the fish of the historic 
record.

Identifying the various fish in the historic record requires descriptive information on their particular physical characteristics. For sturgeon, I noted body size and weight. To distinguish the various species of Oncorhynchus I provided information on physical characteristics including body size, and descriptions of the changes in the physical appearance of spawning salmonids. I also provided information on the preferences the various species of Oncorhynchus have for spawning habitat. Since each species prefers particular stream flows, depths and gravel size, knowledge of these requirements may provide additional information useful for identifying different species.

Most of the information I provide is comparable between species with a few exceptions. As basic resource information I note the average weight and length of the fish. For resident fish I note their range if limited to the study area (some resident fish are found throughout North America) and information that affects their abundance and distribution. I note spawning periods, stream temperatures of spawning areas, and places; prey choices, as that affects aggregation and their main predators. For anadromous fish that do not spawn within the study area, I provide a short comment on their range, connecting these fish to other parts of the Northwest Coast culture area. I note when they enter and pass through the study area; and their body size. For anadromous fish that spawn in the study area I note features that distinguish habitat use such as, stream location, stream size, preferred depth and sediment size used for spawning.

I summarize fish availability and abundance in two kinds of tables: for 
salmon, species are listed by spawning streams within the study area because this information should correlate with historic accounts of places where fish were taken and more broadly suggests the kind of places where certain fish might be targeted. I organized the data on resident fish by noting the type of place where they aggregate and suggested reasons for temporary increases in their numbers. I include the various species of the genus Oncorhynchus in this table to distinguish populations that migrate to the middle and upper Columbia and tributaries to spawn from those populations that spawn in tributaries of the study area.

\section{Anadromous Fish}

\section{White Sturgeon, Acipenser transmontanus}

The white sturgeon ranges from southern Alaska to central California (Parsley et al. 1993:217). Its highest population densities occur in the estuaries of large rivers (Monaco and Nelson 1990:86; DeVore et al. 1995:845). The Columbia River is regarded as the most productive white sturgeon habitat in North America (Collette 1989; Devore et al. 1995).

From 1890-1900, the commercial sturgeon fishery of the lower Columbia was second in value only to the salmon fishery (Craig and Hacker $1940: 205)$. The 1892 commercial sturgeon fishery took $2,721,600 \mathrm{~kg}$ of sturgeon from the lower Columbia

River. By the end of this ten year period the white sturgeon population was drastically reduced (Craig and Hacker 1940).

In 1997 white sturgeon population densities from Bonneville Dam to the estuary were estimated at 516,300 fish between $76-152 \mathrm{~cm}$ in length (DeVore et al. 1999: Table 5). The interval measurement represents the 
current legal size of sturgeon taken in commercial and sports fisheries. Larger fish are excluded from the fisheries.

White sturgeon are long lived, large bodied fish. At 100 years of age white sturgeon may be $6 \mathrm{~m}$ in length and weigh over $580 \mathrm{~kg}$ (Parsley et al. 1993:217). The largest recorded sturgeon weighed $629 \mathrm{~kg}$ (Clemens and Wilby 1961:97) taken in the Fraser River.

The white sturgeon is anadromous, although some individuals live their whole life in freshwater (Monaco et al. 1990). The fish develop slowly, reaching sexual maturity around 11 years. Females generally spawn every 3 to 5 years. The most productive spawners are the older, larger fish (Monaco et al. 1990:87).

White sturgeon are broadcast, surface spawners. Females discharge their eggs near the surface and males their milt over a substrate of boulder and cobble in areas of relative high water velocity, 1.0 to $2.6 \mathrm{~m} / \mathrm{s}$. Spawning occurs from April through July with a peak in May when water temperatures range between $10-18^{\circ} \mathrm{C}$, with a mean of $14^{\circ} \mathrm{C}$. Sturgeon egg survival decreases rapidly in water temperatures over $18^{\circ} \mathrm{C}$ (Parsley et al. 1993:223). Fertilized eggs drift downstream with the current falling through the water column and eventually adhering to the rocky substrate of boulders and cobbles (Parsley et al. 1993 Table 2; McCabe and Tracy 1994:765).

The Cascades (Bonneville) is the first sturgeon spawning area for white sturgeon migrating upstream from the ocean and the Columbia River estuary. Fishery researchers have recovered fertilized sturgeon eggs in the Pierce and Ives Island vicinity, just downstream from Bonneville Dam. No 
other sturgeon spawning areas are present below Bonneville (McCabe et al. 1989:171). Historically, salmon fishwheels placed along the south shore of Hamilton Island during the early 1900's to take spring chinook produced an incidental catch of ripe sturgeon (Donaldson and Cramer 1971). Sturgeon spawning locations are also found farther upstream where water velocity, substrate and temperatures approach those noted.

As the sturgeon larvae develop they separate from the egg sack, detach from the rocky substrate and drift downstream to areas of low current with a sandy substrate (Parsley et al. 1993 Table 2). In these "nursery areas" juvenile sturgeon forage primarily on benthic invertebrates.

During non-spawning periods white sturgeon generally "exhibit a patchy distribution both spatially and temporally" (Parsley et al. 1989:120; National Marine Fisheries Service 1977; Leonard 1987) which probably reflects variation in "temperature, salinity and food" (DeVore et al. 1995:853). Sturgeon also cluster in age specific aggregations, fish composing groups are approximately the same age and size. During daylight, sturgeon tend to be found in deeper sections of the river in depths of $20 \mathrm{~m}$, with a preference for the side slopes of channels. At night, adult and large juvenile sturgeon will forage in water as shallow as $5 \mathrm{~m}$ (Haynes and Gray 1981; Parsley et al. 2004).

Locally, white sturgeon numbers increase as they concentrate to take prey, especially when their prey increases in abundance at particular places. For example, white sturgeon follow and move to intercept migrating eulachon (Haynes et al. 1978:279 citing Bajov 1951; Scott and Crossman 1973). Adult and juvenile sturgeon take eulachon during their migration and as they drift 
downstream after they spawn. Young-of-the-year sturgeon caught in the lower Columbia River in February and March forage on eulachon eggs (McCabe et al. 1989: Table 7:193).

Similarly, white sturgeon numbers may increase in particular locations for periods of time when other fish, such as northern pikeminnow, suckers, or peamouth spawn. Sturgeon also prey upon moribund fall chinook or other species of Oncorhynchus after they spawn. Migrating and spawning lamprey are also taken (Haynes et al. 1978:279; DeVore 1995:853; Wydoski and Whitney 1979:18; Close et al. 2002).

Fisheries researchers take advantage of the foraging patterns of white sturgeon by using set-lines baited with the prey of sturgeon to sample sturgeon populations. They have found that by selecting hooks of a particular size sturgeon of a certain size will generally be taken (Beamesderfer et al. $1989: 49-50)$. This method is considered sufficiently reliable that it is used to sample sturgeon populations to determine population size and gather metric data on the fish.

\section{Green Sturgeon, Acipenser medirostris}

Green sturgeon are rarer and not as well studied as the white sturgeon. The green sturgeon is found mostly in marine environments but is also present in estuaries and the lower reaches of rivers along the Pacific Coast from Ensenada, Mexico to southeast Alaska (Emmett et al. 1991:82). A related variety is found along the coast of northern Japan and Korea (Wydoski and Whitney 2003:40). The current range of the green sturgeon is reduced to a much smaller area because of contemporary impacts to habitat and over fishing. 
Adult green sturgeon are smaller than white sturgeon, reaching lengths of $2.1 \mathrm{~m}$ and weighing $158 \mathrm{~kg}$ (Wydoski and Whitney 2003:40); most of the green sturgeon taken along the North American coast weigh much less, between 22.7 and $45 \mathrm{~kg}$ (Wydoski and Whitney 2003:40). Green sturgeon are shorter lived than white sturgeon. Adult Klamath River green sturgeon were estimated to live up to 60 years (CH2M Hill 1985; Emmett et al. 1991:84).

Green sturgeon spawn from March to July, with a peak in mid-April to mid-June (Adams et al. 2002:7). Preferred spawning habitat is limited to small rivers including the Klamath River, California; and the Rogue River and perhaps the Umpqua River in Oregon (Farr and Rien 2002). In these rivers, green sturgeon spawn in deep holes over a substrate of large cobbles. In estuaries the green sturgeon's highest numbers are found in "deep areas with soft bottoms" (Epic 2001:5).

While systematic studies of green sturgeon are limited, research indicates that green sturgeon are not common in the Columbia River, although there is a notable increase in numbers in the estuary during late summer. Why they increase in numbers is not well understood since they do not feed or spawn in the Columbia River (Adams et al. 2002:i; M. Parsley, personal communication; Rein, personal communication; Farr and Rein 2002). No gravid females have been taken in the Columbia River during recent fisheries research (M. Moser, personal communication).

Green sturgeon have been found in the Columbia River up to Bonneville Dam, Columbia River Mile (CRM) 145, but they are not reported in significant numbers above CRM 38, which is the current upper limit of the estuary. Because green sturgeon do not forage in the Columbia River they are 
not commonly taken on the set-line gear used to sample white sturgeon.

Green sturgeon are caught in small numbers during the commercial summer salmon gill net fishery. Of these over $99 \%$ of the green sturgeon taken commercially are caught below Puget Island, near Cathlamet, Washington.

\section{Eulachon, Thaleichthys pacificus}

Eulachon are found along the Pacific coast from "...the Klamath River, California, to Bristol Bay, Alaska in the eastern Bering Sea and the Pribilof Islands" (Monaco et al. 1990:178). Eulachon are anadromous, entering the Columbia from December through February.

The peak spawning month is February (Monaco et al. 1990:179). During the spawning months, dense schools of eulachon move up the Columbia to spawning locations (Figure 2-1) on the lower reaches of the Kalama, Cowlitz, Lewis, and Sandy Rivers and on the north shore of the mainstem of the Columbia River from Puget Island to about Stella, Wa. (Craig and Hacker 1940:208; Smith and Saalfeld 1955; Hinrichsen 1998). Most of the eulachon spawning areas are in the vicinity of the confluences of tributary streams, except for the Cowlitz River, where they spawn along a $25 \mathrm{~km}$ area from the Columbia confluence to the Toutle River.

The majority of spawning eulachon are three years old. Adult eulachon range in length from $14.0-20.0 \mathrm{~cm}$ and weigh between 40 and $60 \mathrm{gms}$ (Stoffels 2001:2). Eulachon, on their spawning migration, have a high oil content (Department of Fisheries and Oceans 1999:1).

Eulachon mass spawn at night in water $7.5 \mathrm{~cm}$ to $7 \mathrm{~m}$ deep over fine pea-sized gravel with moderate water velocities. Eggs may attach to this substrate as well as to vertical structure such as woody debris and stream 
vegetation (Monaco et al. 1990:179). Spawned out eulachon die (Smith and Saalfeld 1955; Monaco et al. 1990:179).

The Columbia River produced more eulachon than any other stream within its range (Byram and Lewis 2001). In the first half of the 20th century, the Cowlitz River was the most productive of all of the eulachon fisheries.

There are reports of individual commercial dip netters taking 1 to 2 tons of fish per fishing day on the Cowlitz River in the 1930's (Hinrichsen 1998:8). Overall, the commercial catch taken in 1932 was $3,083,357$ pounds, which was about 1/5th of the catch of chinook salmon for that year (Smith and Saalfeld 1955:5).

Eulachon runs show a striking fluctuation in numbers; some streams may not produce a run on any particular year. For example, between 1910 and 1954 eulachon failed to spawn in the Cowlitz River during 8 different years (Smith and Saalfeld 1955). Hinrichsen (1998) cites Hudson Bay Company records and a comment from a homesteader (ca 1850) indicating poor or no runs of eulachon from 1835-1860's and with fish notably absent from the Cowlitz River. The variation in runs and absence of spawning populations in some streams suggests that this rich resource may not be a dependable resource especially for particular locations.

The variation in eulachon abundance is a phenomenon affected by changes in water temperature, variation in river flows, and perhaps ocean conditions. Habitat alteration (logging) and pollution also affect eulachon spawning success (DFO 1999; Monaco et al. 1990:180). However, Hinrichsen (1998) reports of poor runs from 1835-1865, prior to significant habitat alteration, gives support to a natural variation in eulachon numbers.

Eulachon are important primary prey of sturgeon. Both adult and 
juvenile white sturgeon prey on adult eulachon. Young-of-the-year sturgeon consume eulachon spawn (McCabe et al. 1989: Table 7).

\section{Pacific Herring, Clupea harengus}

Pacific Herring are present along the coastal areas of the Northwest Coast from Humboldt Bay, California through Arctic Alaska (Eschmeyer 1983:71; Lassuy and Moran 1989). Herring are considered common in the Columbia River estuary from March through July (Monaco 1990: Table 3). Herring spawn along both shorelines of the Columbia River from near the mouth to a point approximately $55 \mathrm{~km}$ upstream (Lassuy and Moran 1989: Figure 2).

Throughout its range, Pacific herring spawning periods corresponding to "local spring conditions", specifically to an increased plankton production (Lassuy and Moran 1989:2). Herring probably spawn in late winter-early spring in the Columbia River. They spawn in large schools, over vertical substrates such as eel grass beds, pilings, rock and brush (Monaco et al. 1990).

Herring mature at 3 years and may live up to 19 years. Adults range in length from 13 to $26 \mathrm{~cm}$. Herring spawn seasonally and multiple times over their life span with the highest fecundity associated with older females.

Pacific herring are currently taken in the Columbia River as a bait fish (McCrae 1994). Craig and Hacker (1940) identified commercial fisheries on the Columbia but did not include the Pacific herring. It is likely that the herring numbers were insufficient to support a commercial enterprise in the Columbia River. 


\section{Pacific Lamprey, Lampetra tridentata}

Three species of lamprey are present in the Columbia Basin, Lampetra richardsoni, western brook lamprey; Lampetra tridentata, Pacific lamprey; and Lampetra ayresi, river lamprey (Wydoski and Whitney 2003). Pacific lamprey is the species reported as part of the traditional diet of Native Americans in the Pacific Northwest (Close et al. 2002). The other two species, western brook and river lamprey are much smaller in body size. The following remarks are limited to the Pacific lamprey.

The Pacific lamprey is found along the Pacific Coast from the Aleutian Islands to the Baja Peninsula, Mexico. Pacific lamprey spawn and the larvae develop in the "the upper reaches of most rivers draining into the Pacific Ocean" (Close et al. 2002:20).

Lamprey are anadromous, spending most of their adult life, 20 months to 3.5 years, in the ocean. As they mature in the ocean, adult lamprey accumulate reserves of carbohydrates, lipids and proteins (Close et al. 2002: 21; Hunn 1990:160) that sustain them as they migrate to spawning grounds; like salmon they do not feed after entering freshwater.

Mature lamprey enter freshwater between April and June. Adult lamprey migrate in schools to (most likely) their natal streams (Hunn 1990:160). (An unresolved question about lamprey spawning is its 'fidelity' to natal streams. While they may return to natal streams, the percentage is unknown). Once adult lamprey reach their spawning streams they over-winter, spawning the following spring (Close et al. 2002:21 citing Beamish 1980). Eggs are laid in nests in stream gravels. Within two to three weeks lamprey larvae leave the nest and drift downstream to pools and eddies where they burrow into silt and 
mud. The larvae spend 4-6 years as filter feeders before they start their downstream migration to the ocean as juveniles (Close et al. 2002 citing Haynes et al. 1978).

Pacific lamprey migrate through and spawn within the study area. The migration period extends from April through June (Close et al. 2002:21) and perhaps into July (Mattson 1949:27).

Michael (1984; cited by Wydoski and Whitney 2003:35) reports that spawning adults in the Kalama River (counting post spawning adults moving downstream) numbered 7,000 in 1979 and 13,000 in 1981. At Willamette Falls the commercial fishery for lamprey took $347,260 \mathrm{lbs} .(157,517 \mathrm{~kg})$ in 1946 and $114,685 \mathrm{lbs} .(52,021 \mathrm{~kg})$ in 1949 (Mattson 1949:26). In the past, fluctuating water levels prevented late arriving lamprey from crossing over Willamette Falls. Unable to cross, "thousands of [lamprey] carcasses" drifted downstream from the falls (Mattson 1949:27).

The accumulated reserves of the lamprey makes them a prime prey of many species of mammals, birds and fish. On spawning migrations, adult lamprey "are the most abundant dietary item in seals and sea lions" (Close et al. 2002:21). White sturgeon forage on spawned out lamprey (Close et al. 2002:21 citing Semakula and Larkin 1968; Galbreath 1979). Downstream migrating juveniles are an important prey of juvenile coho, northern pikeminnow and many species of birds (Close et al. 2002:21).

\section{Oncorhynchus spp.}

Six species of anadromous salmon and trout are present in the Columbia River basin: Oncorhynchus tshawytscha, chinook salmon; 0 . kisutch, coho salmon; O. keta, chum salmon; and O. nerka, sockeye salmon. 
O. gorbuscha, the pink salmon is present but rare in the lower Columbia (Fulton 1970:2) and is not included in the following discussion. O. mykiss, steelhead trout, recently reclassified from Salmo gairdneri, is the final species considered in this section.

Most species of the genus Oncorhynchus are anadromous. Adults spawn in a range of freshwater habitats from the mainstem of the Columbia River, its major tributaries and small streams. All members of the genus Oncorhynchus spawn in redds, gravel basins excavated by the adults. Dimensions of the redds, water depth and the gravel size used for their redds are specific to each species.

Except for some steelhead, adults die after spawning. Young salmon emerge from spawning sites and depending on species spend from a few weeks to more than a year in freshwater before they migrate downstream to the sea. Depending on species, adults live in the sea from 2 to as long as 7 years before they return to the Columbia River. At the conclusion of their ocean phase, salmon generally migrate to their natal stream where they spawn, die and the cycle begins again (Monaco et al. 1990; Behnke 2002).

All salmon go through physical changes as they migrate and prepare to spawn. Salmon do not feed as they make their spawning run. The reserves of fat and protein they built up in the ocean sustain them on their migration. Some species can be identified by changes in their external appearance. The change in physiology, reduction of fat, and breakdown of tissue may affect human selection of different species and may also influence the selection of stocks within particular species.

All of the salmon that migrate into the Columbia River system pass 
through the study area. The length of stay in the estuary varies with the species and sometimes with the stock, and their destination, although there is little information for many of these fish on this matter. Those that spawn within the study area, stage at the confluence of various tributaries of the Columbia River and then move up these streams to spawn.

Adult salmon are preyed upon by humans, bears and other mammals; birds, including bald eagles (Haliaeetus leucocephalus), and osprey (Pandion haliaetus); Pacific lamprey, harbor seals (Phoca vitulina) and sea lions (Monaco et al. 1990). White sturgeon forage on spawned out moribund salmon (DeVore et al. 1995:853).

\section{Chinook Salmon, Oncorhynchus tshawytscha}

Chinook salmon are present along the Pacific Rim from Japan to southern California (Monaco et al. 1990:161). The Columbia River basin once produced more chinook salmon than any other river system (Fulton 1970:2), although current production is a fraction of its historic levels.

Columbia River chinook have an extended migratory period, which is divided into spring, summer and fall runs. The major runs can be further divided into subgroups [stocks], with different spawning areas and variable life history characteristics (Behnke 2002:26). Chinook spawn in larger rivers and at deeper depths, up to $10 \mathrm{~m}$, than other salmon (Monaco et al. 1990:163). They spawn in larger gravel, $1.3-10.2 \mathrm{~cm}$, than other species of Oncorhynchus (Reiser and Bjornn 1979; Monaco et al. 1990:163).

Chinook salmon reach 71-102 cm in length and weigh between 4.5$11.3 \mathrm{~kg}$ (Behnke 2002:25). Within this range spring, summer and fall run chinook have different average weights. Fulton (1968:3) reports: spring run 
averaging $6.8 \mathrm{~kg}$; summer run $6.4 \mathrm{~kg}$, and the fall run is the largest, averaging $8.2 \mathrm{~kg}$. An exception to these trends are the so called June Hogs, a summer chinook stock that formerly migrated $1932 \mathrm{~km}$ up the Columbia and weighed from 18-27 kg (Fulton 1968:4). Record chinook may weigh nearly $60 \mathrm{~kg}$ (Emmett et al. 1991:163; Behnke 2002:25).

Spring and summer runs are adapted to a long extended spawning migration (Fulton 1968: Table 3). These fish are the least mature as they enter the Columbia River. Their rich flesh is heavy with fats and oils that sustain them on their migration and provides the nutrients needed for egg development. When these fish are intercepted early in their migration they are a rich resource, but over the passage upstream their oil and fat content decreases and their flesh breaks down.

In contrast, fall chinook, especially those that spawn in tributaries of the Columbia River estuary, enter the river with nearly mature eggs and signs of full maturity. These fish move up into their spawning streams within a few weeks after they enter the estuary and then spawn. Although edible, these fish are reduced in oils and fats, and their tissue is breaking down because they are near completion of their life cycle.

One of the distinctive external features of chinook salmon are the black spots or markings above the lateral line and on the upper and lower lobes of the caudal fin. As chinook mature their color darkens from silver to "reddish brown or maroon" and the kype (hooking of the maxillary over the mandible) develops. The changes in chinook salmon are not as profound as in the pink, chum, or sockeye salmon (Behnke 2002:26).

The spring and summer runs were the initial focus of the historic 
commercial fishery. Those caught between the mouth and the Cascades at Bonneville Dam have a high fat content, firm flesh and do not display the outward color change of fish just before they spawn. They tend to spawn no sooner then two months after they enter the river. Commercial processing of these fish was relatively easy. In 1883, 19.5 million $\mathrm{kg}$ of spring and summer chinook were taken in the fishery. A sharp decline in the spring and summer runs continued through the decade and into the next century.

The commercial fishery for fall run chinook developed in the 1890's, after the spring and summer runs had been fully exploited and were in decline (Fulton 1970:20). Fall chinook are difficult to process because they are leaner and have the softer flesh of more mature fish. The commercial fishery for fall chinook developed only after methods for processing a more mature fish were developed.

Spring chinook move through the study area from February through May, passing the Bonneville area from early March through the beginning of June (Fulton 1970:3; 1968: Table 1). The spring run migrates the farthest, spawning in the small streams and the headwaters of the larger tributaries of the lower (including five within the study area), middle and upper Columbia and upper tributaries of the Willamette River. Spring chinook are the only salmon that migrate into the Willamette River basin above Willamette Falls (Table 2-1). After the spring run, water levels in the Willamette drop, making it impossible for salmon to pass over Willamette Falls.

Summer chinook move through the lower Columbia River from June through August mostly through the main stem and the medium sized tributaries of the middle and upper reaches of the Columbia River (Fulton 
1970:3). A smaller number of these fish spawn in the upper Cowlitz River and its tributaries (Table 2-1).

Fall run chinook enters the study area from mid-August through October and spawns from September through December. Fall chinook spawn in lower Columbia River tributaries from the mouth of the Columbia up through the main stem of the middle Columbia and Snake Rivers (Fulton 1970:3). Fulton (1968:22) inventoried fall chinook spawning streams in the study area (Table 2-2), but his report notes that he only counted streams with at least 1000 spawning chinook. By implication, additional spawning streams, no longer available for fall chinook spawning because of habitat disturbance, were present increasing the number of streams where these fish might be found over the number reported. Fulton's (1968) inventory is an example of the limitation of modern data compared to conditions in the middle to early 19th century.

Fall chinook are distinguished from spring and summer runs primarily by timing, but, as noted above, they are also more mature than the other two stocks. Populations that spawn in tributaries near the mouth of the Columbia have very short spawning runs to make. Within a very short time after they enter the river, their coloration changes, the quality of their flesh declines, and the kype develops. Spring and summer chinook, in contrast, are in prime condition as they pass through the study area, exhibiting none of the physical changes that occur just before spawning.

\section{Coho Salmon, O. kisutch}

Coho range from northern Japan to Monterey, California. They are most abundant between southern Oregon and southeast Alaska (Laufel et al. 
1986:1).

Most coho salmon return to spawn when they are 3 years old. The typical 3 year -old coho is $61-71 \mathrm{~cm}$ in length with a few reaching $99 \mathrm{~cm}$ in length. They generally weigh between $3.6-4.5 \mathrm{~kg}$ with a maximum of $15 \mathrm{~kg}$ (Behnke 2002; Laufel et al. 1986:3).

Coho may appear as early as late August but most of the run enters the river from mid-September to about mid-November (Fulton 1970:12). Coho spawn within a week after arriving at their spawning stream. They spawn mostly from November to January with a few as late as February with stream temperatures of $4-14^{\circ} \mathrm{C}$ (Monaco et al. 1990:138).

Coho spawn in small coastal streams and the tributaries of the Columbia River (Table 2-3) from the mouth to about $240 \mathrm{~km}$ upstream (Fulton 1970:12; Laufel et al. 1986:3). Unlike most other salmon, coho can spawn in gravels with up to $10 \%$ mud and in small streams and tributaries with water depths as shallow as $18 \mathrm{~cm}$. As a consequence coho can spawn in shallower water with lower stream velocities and a smaller gravel substrate than chinook (Laufel et al. 1986:3). Coho and chinook salmon may spawn in the same rivers and streams but are not in competition for spawning locations because they use different places with different gravel sizes and stream depths.

Migrating adults change from their ocean silver color to a deep red (darker in males) by the time they arrive at their spawning stream. The males develop a pronounced kype. These features may be present on females but they are not as exaggerated as they are in males (Fulton 1970:12). Coho have 
a few black spots or markings on the upper lobe of the caudal fin while chinook are marked on the upper and lower lobes of that fin.

The Columbia River coho supported an important commercial fishery with peak catches in the 1920 's. Fulton reports $3,600,000 \mathrm{~kg}$ of coho processed in 1925 (1970:19).

\section{Chum Salmon, O. keta}

The chum's range includes most of the north Pacific Ocean from Korea and Northern Japan along the west coast of North America to the Sacramento River, California. However, the chum is not considered abundant south of the Rogue River, Oregon (Monaco et al. 1990:128).

On the Fraser River and in Puget Sound, fall, winter, spring and summer chum spawning populations are present. The lower Columbia River chum are fall spawning with adults arriving from October through December (Wydoski and Whitney 2003:68; Monaco et al. 1990). Fulton (1970) reports that historically, most of the chum spawned below The Dalles (Table 2-4); currently, chum are not common above Bonneville Dam (Wydoski and Whitney 2003:68).

Four year old adult Columbia River chum weigh 3.6-5.4 kg (Fulton 1970:29). Adult chum average $61-79 \mathrm{~cm}$ in length but some can reach lengths of $107 \mathrm{~cm}$ (Monaco et al. 1990:130; Behnke 2002:51). Chum spawn in shallow water "at the head of riffles...or side channels where water velocities are lower" (Wydoski and Whitney 2003:69). Chum spawn in gravels 2 to $4 \mathrm{~cm}$ in diameter with up to $6 \%$ mud-silt-sand (Monaco et al. 1990:129). Chum fingerlings spend the shortest time in freshwater of all of the salmon (Fulton 1970) migrating to brackish water as fry. 
Some adults spend less than a week in freshwater before spawning, although most fish spawn within a few weeks after entering freshwater (Monaco et al. 1990). As a consequence, chum enter the estuary more mature than any other species of Oncorhynchus. "Chum salmon begin to rapidly deteriorate, both internally and externally, as spawning time nears. These changes begin while the salmon are still in marine waters and as they congregate to enter freshwater and accelerate rapidly thereafter" (Behnke 2002:54). Chum coloration at spawning is distinctive from other salmon. They "have greenish to dusky mottling on the sides, and males have reddishpurple vertical markings" (Wydoski and Whitney 2003:68). According to Behnke (2002: 52) adult fish may have streaks of red, blue and green.

The process of deterioration includes the breaking down of protein "...turning the flesh from firm to mushy. In the males, the teeth greatly enlarge, especially near the tip of the lower jaw-thus the common name dog salmon" (Behnke 2002:52). They also "...have the lowest fat content of all the salmon species" (Behnke 2002:54).

At one time the commercial chum fishery on the lower Columbia River was economically important, although this fishery did not develop until the chinook salmon fishery was in serious decline from over fishing and habitat change. In $1928,3,854,000 \mathrm{~kg}$ of chum were taken in the Columbia River (Fulton 1968:29), representing about 964,000 fish (Bell 1984).

Commercially, chum was a lower valued fish (Martin 1994:85). Chum salmon flesh is pale pink not the bright red of other salmon and its flesh was soft with a lower oil content, a sign that its flesh is breaking down. However, the reduced oil content made it easy to smoke, one of the more common 
methods of processing this fish (Fulton 1970:29).

\section{Sockeye Salmon, O. nerka}

Sockeye salmon's range extends around the Pacific Rim from Japan to the Columbia River. Sockeye migrate in the Columbia River from May through August (Fulton 1970: 23). Sockeye may be a resource that clumps, large numbers of the fish are present over a short period of time. On the Klukshu River in the southwest Yukon, for example, half the sockeye salmon run passes in 7.5 days... (Ames and Maschner: 1999:116). June and July are the months when the majority of sockeye pass over Bonneville Dam. The largest numbers of sockeye pass the dam over a 40 day period starting in the middle of June (Portland District 2005).

Adult sockeye may reach a length of $53-66 \mathrm{~cm}$ and weigh up to $7 \mathrm{~kg}$, although most adult fish weigh 1.5 to $3.6 \mathrm{~kg}$ (Wydoski and Whitney 1979:62). The Columbia River sockeye falls at the low end of this range, weighing on average $1.7 \mathrm{~kg}$ (Fulton 1968:23).

Sockeye salmon spawn in streams that are tributaries of lakes or along lake shorelines. There is no sockeye spawning habitat within the study area. The Deschutes and Yakima Rivers are the nearest Columbia River tributaries leading to sockeye spawning areas. Prior to the construction of the Grande Coulee Dam, sockeye migrated up the Columbia River as far as the Arrow Lakes in Canada, a distance of $1930 \mathrm{~km}$ from the mouth (Behnke 2002:6162 ) and up the Snake River to Redfish Lakes in Idaho, a distance of around $1000 \mathrm{~km}$.

At maturity the sockeye is brilliant red. The male's teeth enlarge and its jaws curve forming a substantial kype. An exaggerated hump forms behind 
the head. There are no spots on the caudal fin (Behnke 2002:59). These features do not become apparent until the fish have migrated outside the study area.

The lower Columbia River sockeye salmon fishery accounted for a significant portion of the sockeye catch. Fulton reports that $2,056,000 \mathrm{~kg}$ were taken in the Columbia River in 1898 (1968:24). It is still an important commercial fish in the Fraser River of British Columbia area, but in the Columbia River basin about $95 \%$ of its habitat was lost to hydroelectric and irrigation dams (Behnke 2002:63; Fulton 1970; Wydoski and Whitney 1979:62; Monaco et al. 1990:152).

\section{Steelhead, O. mykiss}

Steelhead are the sea-run variant of 0 . mykiss. The coastal rainbow trout, O. mykiss irideus found west of the Cascades and in Pacific Coastal streams and the rainbow trout, 0 . mykiss gairdneri, found east of the Cascades (Behnke 2002) include anadromous and resident populations. The steelhead's historic range was limited to the Pacific Coast from northwestern Mexico to the Kuskokwim River in SW Alaska (Monaco et al. 1990:146). They are widely distributed in the Columbia River drainage (Fulton 1970:3).

Wydoski and Whitney (2003:76; see also Behnke 2002:69) suggest that steelhead migrate into the Columbia River every month of the year. Though, according to Fulton (1970), most of the steelhead are either winter run, migrating from November through April, or summer run, migrating May though October. Behnke (2002:76) adds a spring and fall run. According to Behnke (2002:76) spring and summer run migrate from May through August; the fall run from September through November; and the winter run from 
December through March (see also Monaco et al. 1990:148; Fulton 1970:3).

Regardless of their migration timing, all steelhead spawn in the spring.

Fish hold over in freshwater for varying lengths of time depending on their particular migration period. Those fish that spend the longest time in freshwater, the spring and summer runs, tend to be those that migrate the farthest and are the least mature when they first enter freshwater.

In contrast, winter steelhead spawn soon after entering freshwater. Winter run steelhead spawn mostly in Columbia River tributaries below Bonneville Dam (Table 2-5). The summer run spawns in tributaries above the Klickitat River (Fulton 1970: Table 3).

Steelhead spawn in gravel ranging around $8.5 \mathrm{~cm}$ in diameter (Monaco et al. 1990:147). Fertilized eggs may be buried under as much as $30 \mathrm{~cm}$ of gravel. The eggs hatch after about 50 days in stream temperatures of $10^{\circ} \mathrm{C}$. Although $90-95 \%$ of the eggs are fertilized, only $65-85 \%$ hatch, due mostly to suffocation by silt (Wydoski and Whitney 1979:46).

Adult steelhead vary in size depending on the length of time they spend in the ocean and the number of migrations they make from fresh to salt water. Unlike other anadromous salmonids, about 10 to $20 \%$ of steelhead trout return to the sea and then migrate to freshwater spawning grounds to spawn again (Behnke 2002:76). Fish that return for a second and third spawning are larger than those that only spawn once. Steelhead spawn first as 2 to 3 year old fish (Behnke 2002:69). These fish range in length from $45-70 \mathrm{~cm}$ and weigh $2-5 \mathrm{~kg}$. However, steelhead can reach nine years in age, $122 \mathrm{~cm}$ in length and weigh $19.5 \mathrm{~kg}$ (Washington 1970, Scott and Crossman 1973 and 
Hart 1973 cited in Monaco et al. 1990:148).

Non-migratory resident rainbow trout are common to the streams and lakes of the northwest. Different populations, apparently, have variants that are anadromous migrating to the sea and returning as steelhead (Wydoski and Whitney 1979; Behnke 2002). Residents are distinguished from migrants by their much smaller size. Typical resident trout are $15-20 \mathrm{~cm}$ long and weigh $57 \mathrm{~g}$ in small streams; in lakes they range between $30-41 \mathrm{~cm}$ in length and weigh $0.45-0.68 \mathrm{~kg}$ (Behnke 2002:75). There is considerable variation in size and weight given water temperatures of particular lakes or streams and food supply (Wydoski and Whitney 1979:43).

\section{Cutthroat trout, 0 . clarki clarki}

Like the rainbow trout, there are two variants of the coastal cutthroat trout. One migrates to the sea growing faster and larger than the freshwater resident form. Resident cutthroat in small streams, reach lengths of $13-20 \mathrm{~cm}$ and weigh $11-91 \mathrm{gm}$. A record cutthroat caught in a lake weighed $5.4 \mathrm{~kg}$. Searun forms reach 41-56 cm and weigh 0.9-2.3 kg (Behnke 2002:75).

\section{Marine Fish}

\section{Surf Perch}

The historic literature I cite includes one possible reference to surf perch. Eschmeyer et al. (1983:226-232) report that the family Embiotocide includes 18 species, with 9 species found along the Oregon Coast and in brackish waters. Some of these fish support commercial fisheries, indicating they have a presence that is more than incidental. However, the historic reference I cite does not provide sufficient detail to define a species, consequently, these fish are not further discussed. 


\section{Resident Fish}

\section{Starry Flounder, Platichthys stellatus}

The starry flounder is a common flatfish found along the Pacific Coast and in estuaries from Japan to southern California. Juveniles and adults are also found in rivers above estuaries (Eschmeyer et al. 1983; Monaco et al. 1990; Farr and Ward 1993:20). The starry flounder is widely tolerant of variations in salinity, and may be found in fresh water. In the Columbia River they are found throughout the study area up to the Willamette River (Johnson and Fishman 1996; Hinton et al. 1990; Farr and Ward 1993).

Juvenile starry flounder range in size from $17-30 \mathrm{~cm}$ becoming mature adults in 2 to 3 years. Mature males are typically $17-30 \mathrm{~cm}$ in length and females $23-35 \mathrm{~cm}$. The maximum age for males is 24 years and females, 17 years; both can reach a maximum length of $91 \mathrm{~cm}$ and weigh up to $17 \mathrm{~kg}$ (Orcutt 1950 quoted in Monaco et al. 1990; Hart 1973).

Adults move inshore during the winter and early spring and offshore during summer and fall. Adults and juveniles prefer a soft bottom of "mud, sand or gravel but not rock" (Monaco et al. 1990:267). Adults and juveniles will hide themselves by altering their coloration to blend in with the substrate and by covering themselves with sand or mud.

The starry flounder spawns near river mouths and in sloughs in water less than $45 \mathrm{~m}$ deep. Spawning occurs from winter into early spring with a spawning period of February to April for Puget Sound and British Columbia (Monaco et al. 1990:268).

Upwards of 2,000 starry flounder have been taken by seining during fisheries research in the Columbia River estuary (Hinton et al. 1990). Smaller 
quantities of this fish have been taken in the vicinity of the confluence of the Clatskanie and Columbia Rivers (Johnson and Fishman 1996). The commercial fishery for starry flounder is offshore in marine waters. In the estuary, anglers take starry flounder with bait and lures (Lamb and Edgell 1986:204).

Other members of the family Pleuronectidae, commonly known as flatfish, are much less common in the estuary. Pleuronectes vetulus, English sole, juveniles may be present using estuaries as rearing habitat (Lassuy and Moran 1989:4), although, Monaco et al. (1990: Table 3) report them as absent.

\section{Threespine Stickleback, Gasterosteus aculeatus}

The threespine stickleback is a resident of the Columbia River. They are found in a wide variety of habitats ranging from near shore shallow marine environments to freshwater. The stickleback is regarded as common and abundant in its preferred habitat of lakes, slow moving streams and rivers, and sheltered coastal bays (Wydoski and Whitney 2003:167). Marine populations of the species are anadromous, leaving ocean environments to spawn in freshwater. Fishery studies in British Columbia indicate that the anadromous populations range within the tidally influenced portions of streams. Freshwater populations rarely enter tidal areas. Marine and freshwater populations hybridize at the margins between tidal and freshwater and these hybrids display intermediate traits. Anadromous and steamresident populatlons are considered separate gene pools of a single species (McPhail 1994).

Threespine stickleback are armored with bony lateral plates, rather 
than scales and have projecting dorsal spines. They are small fish ranging in size from 70-110 mm (Wydoski and Whitney 1979; Reimchen 1994:241)

Stickleback are usually found in schools securing individual territories only during its reproductive phase and as the eggs develop. Wydoski and Whitney (2003:167) report large schools of fish in marine environments. Resident threespine stickleback spawn in freshwater from May through July with some spawning as late as August. Threespine stickleback from marine environments typically spawn in early June (Wydoski and Whitney 1979:114).

While a small fish, it is common and possible to take large numbers of stickleback. In one beach seining set in September 1989, fishery researchers in the vicinity of CRM 23 took over 500 stickleback (Hinton 1990: Table 25). Over 7,500 stickleback were taken during a May-September 1994 sampling period with a $36 \mathrm{~m}$ long seine in Trestle Bay, a Columbia River intertidal and sub-tidal backwater near the Columbia River mouth (Hinton and Emmett 2000:25). Stickleback have also been netted in the mainstem of the Columbia River at CRM 50, in the vicinity of the Clatskanie River; and at CRM 105, upstream from the confluence of the Willamette and Columbia River (Johnson and Fishman 1996).

Their small body size, abundance and slow swimming speed makes them easy prey. Reimchen lists 68 species that prey on the stickleback including, rainbow trout, cutthroat trout, coho salmon juvenile and adults, northern pikeminnow, Podicipedidae spp grebes, Ardea herodias, great blue heron, Lophodytes cucullatus, hooded, Mergus merganser, common merganser, Larus spp, gulls, Alcedinidae sp kingfishers; Lutra canadensis, otters, Callorhinus ursinus, fur seal; and humans (1994:243-244). Over an 
eight year study period, it was found that $80 \%$ of a cutthroat trout's diet was composed of stickleback.

\section{Minnow, Cyprinidae}

There are many species of minnow in the lower Columbia. The ones I discuss are those recovered in lower Columbia archaeological contexts. Only one minnow was reported in the historic record of the study area.

\section{Chiselmouth, Acrocheilus alutaceus}

Chiselmouth are common and abundant east of the Cascades and present in the Willamette, lower Columbia River and estuary (Wydoski and Whitney 2003:118; Farr and Ward 1993). It may reach lengths of $30 \mathrm{~cm}$ and weigh $680 \mathrm{~g}$.

Little is known of its behavior and life history. It prefers warm temperatures with slow currents. In the Willamette River chiselmouth spawn when water temperatures exceed $15^{\circ} \mathrm{C}$, usually from April to June with a peak in May (Wydoski and Whitney 2003:119). They are presumed to be broadcast spawners, although there is no first hand observation of these fish spawning, as their fertilized eggs are found adhering to open substrate of rock of various sizes (Wydoski and Whitney 2003:119).

Chiselmouth are grazers. They have a specialized lower jaw that allows them to scrape vegetation, diatoms and insect larvae from rocks and other substrate (Wydoski and Whitney 2003:120).

\section{Northern pikeminnow, Ptychocheilus oregonensis}

The northern pikeminnow has been intensively studied because it is considered one of the major predators of juvenile salmon. This has lead to a 
body of information and data on this species. The northern pikeminnow is found throughout the Columbia River basin, coastal and Puget Sound drainages and British Columbia (Wydoski and Whitney 1979:85).

Fourteen year old northern pikeminnow, downstream from Bonneville Dam, ranged in size from $46 \mathrm{~cm}$ to $51 \mathrm{~cm}$. Fish 19 years old reach lengths of $62.5 \mathrm{~cm}$. The largest recorded pikeminnow weighed $13.6 \mathrm{~kg}$. Older, larger fish tend to be females (Wydoski and Whitney 1979:85).

Northern pikeminnow spawn from May to late July when water temperatures are between $13-17^{\circ} \mathrm{C}$ (Mullan et al. nd:28; Carl et al. 1973:109). On the middle Columbia River [CRM 473, near Wenatchee, Wa.] they spawn from late June to early July (West 2002). The female broadcasts small greenish eggs which, when fertilized, adhere to the rocky substrate. With water temperatures at $18^{\circ} \mathrm{C}$, the eggs will hatch in about 7 days becoming free swimming fish in 14 days (Wydoski and Whitney 1979:86).

Columbia River northern pikeminnow spawn over a substrate of gravel and rubble with water velocities ranging between $0.2-1.3 \mathrm{~m} / \mathrm{s}$. Substrate and current conditions suitable for northern pikeminnow are found in the tail races of dams, at the most upstream end of some of the pools of the dams and in some of the tributaries flowing into the river (Gadomski et al. 2001:251). Similar substrate and water velocities were probably favored prior to the construction of hydroelectric facilities. The fish also spawn on the edges of lake shores if suitable substrate is present (Mullan et al. nd:28). No spawning occurs over mud or silt (Gadomski et al. 2001:250).

Concentrations of spawning northern pikeminnow have been reported 
to range from a few hundred to several thousand (Gadomski 2001:250).

Patten and Rodman (1969) reported groups of 2000 to 8000 spawning northern pikeminnow over a 12 day period in the Merwin Reservoir on the Lewis River. During spawning, Catostomus macrocheilus, largescale sucker, and Cottus asper, prickly sculpin, were present. Both fish were drawn by and foraged on the eggs of the spawning northern pikeminnow (Patten and Rodman 1969:109).

As northern pikeminnow mature they switch from a diet of insects, both aquatic and terrestrial, to one composed of fish. Northern pikeminnow are a primary predator of juvenile salmon (Wydoski and Whitney 1979:86; West 2002) as well as other small fish. Northern pikeminnow concentrate along shallow shorelines intercepting juvenile salmon as they migrate downstream.

Northern pikeminnow is regarded as edible although it is not commonly eaten (Wydoski and Whitney 1979:86). There has never been a commercial fishery for northern pikeminnow.

\section{Peamouth chub, Mylocheilus caurinus}

Peamouth chub is a resident fish of the Columbia River basin, British Columbia and Vancouver Island (Wydoski and Whitney 1979:88). Though the fish is predominantly a freshwater fish, its tolerance for salt water may account for its presence on Vancouver Island, as it is the only native minnow on the island. It is also abundant in the Columbia River estuary and throughout the study area (Mullan nd: 26; Hinton et al. 1990; Johnson and Fishman 1996).

Peamouth tend to remain on the bottom when water depth is less than $18 \mathrm{~m}$. In deeper water the fish is found within $6 \mathrm{~m}$ of the surface. "Older fish 
feed on plankton, aquatic and terrestrial insects, and occasionally small fishes such as sculpins." (Wydoski and Whitney 1979:89).

Males mature at 3 years and females at 4 years. Females live up to 13 years in some environments with males reaching 9 years. Mature peamouth can reach over $33 \mathrm{~cm}$ in length. Females are generally larger (Wydoski and Whitney 1979:88-89).

Peamouth spawn from late May through early June in British Columbia when water temperatures reach $12^{\circ} \mathrm{C}$. Spawning areas are located in streams and along lake shorelines in gravel and rubble. Large schools of peamouth spawn during twilight. Small yellow eggs are broadcast near the bottom of the spawning areas adhering to the substrate (Wydoski and Whitney 1979:88-89).

Peamouth were taken commercially in the 1880 's for the restaurant trade (Wydoski and Whitney 1979:88-89), although it is not commonly eaten today. During a white sturgeon monitoring study in late August and early September in the Columbia River estuary, 542 peamouth chubs were netted during 10 gill net sets (Ramano and Rien 2001:5).

\section{Dace, Rhinichthys spp.}

There are three species of Rhinichthys reported in the study area, $R$. cataratae, $R$. falcatus and R. osculus (Wydoski and Whitney 2003). Speckled dace, $R$. osculus, is the most abundant.

Speckled dace prefers shallow cool, relatively fast moving water. It has a life span of approximately 3 years and may reach a maximum length of 10 $\mathrm{cm}$. Speckled dace spawn in riffles of small streams in a small gravel 
substrate in water temperatures of $18^{\circ} \mathrm{C}$ (Wydoski and Whitney 1979:93-94).

\section{Sandroller, Percopsis transmontana}

Sandroller is rare and poorly studied. They have been taken in the main stem of the Columbia during fishery research (Johnson and Fishman 1996:

Table 4 and Table 5), but are also found in quiet backwaters (Wydoski and Whitney 1979:116). Sandrollers average $7.5 \mathrm{~cm}$ in length, rarely exceeding $12.5 \mathrm{~cm}$, and weigh around $85 \mathrm{~g}$ (Wydoski and Whitney 1979:117). They spawn from June to mid-July in streams when water temperatures are between $14^{\circ}$ and $16^{\circ} \mathrm{C}$.

\section{Suckers, Catostomus spp.}

There are four species of suckers residing in the Columbia River and its tributaries but only Catostomus macrocheilus the largescale sucker, is common to the study area. C. columbianus, bridgelip sucker, is a common resident fish on the east side of the Cascade Mountains, although a few have been taken downstream of Willamette Falls during fisheries research (Farr and Ward 1993). C. platyrhynchus, mountain sucker, is found in the clear, cold water of mountain streams; and C. catostomus, longnose sucker, prefers cold-water lakes and streams.

\section{Largescale sucker, Catostomus macrocheilus}

Largescale suckers have been taken in the upper estuary of the Columbia River at Taylor Sands (CRM 15-16) and farther upstream (Hinton 1990; Johnson and Fishman 1996). The largescale sucker was one of the most common fish captured by Farr and Ward (1993) during their study of fish in the lower Willamette River. It is generally found in water less than $24 \mathrm{~m}$ 
deep.

The largescale sucker can weigh up to $3.2 \mathrm{~kg}$ and reach lengths of 60 $\mathrm{cm}$, at its maximum age of 11 years. At age 7 the fish is typically $41 \mathrm{~cm}$ long (Carl et al. 1973:138; Wydoski and Whitney 1979:98).

The largescale sucker grazes the algae mat growing on the surface of boulders and rubble consuming aquatic insect larvae and eggs, algae, diatoms, earthworms, snails, amphipods, mollusks, and fish eggs (Carl et al. 1973:88; Wydoski and Whitney 1979:97-98).

These fish move to spawning areas in April through May as water temperatures reach $8-9^{\circ} \mathrm{C}$, spawning when the water reaches $12-16^{\circ} \mathrm{C}$. They spawn primarily at the outlets or inlets of streams of lakes or along the shoreline of lakes in water as shallow as $20 \mathrm{~cm}$. Males stay on the spawning ground over an extended period of time while females enter spawning areas, deposit eggs and leave (Carl et al. 1973:88; Wydoski and Whitney 1979:98). Small yellow adhesive eggs are broadcast over a substrate of gravel and sand.

\section{Seasonal Aggregation}

I have taken information from my discussion to identify periods when the fish I have identified as potential resources in the study area are concentrated in the greatest numbers (Table 2-6). If human decision making targets fish when they occur in the greatest numbers, then spawning periods, spawning migrations and periods of predation on concentrated and abundant prey are events when large numbers of fish are present. 


\begin{tabular}{|l|l|l|c|}
\hline \multicolumn{3}{|c|}{$\begin{array}{l}\text { Table 2-1 } \\
\text { Spring and Summer Chinook Spawning Tributaries between Bonneville } \\
\text { and the mouth of the Columbia River } \\
\text { (adapted from: Fulton 1968, Table 2) }\end{array}$} \\
\hline \multicolumn{1}{|c|}{ River } & Oregon & $\begin{array}{l}\text { Washingto } \\
\text { n }\end{array}$ & Km from Mouth \\
\hline $\begin{array}{l}\text { Cowlitz River (upper section of main river) } \\
\text { Kalama River (middle and upper portions } \\
\text { of main stem) }\end{array}$ & & $\begin{array}{c}\text { spring/ } \\
\text { summer }\end{array}$ & 105 \\
\hline $\begin{array}{l}\text { Lewis River (Lower portion below Merwin } \\
\text { Dam, springs) }\end{array}$ & & spring & 121 \\
\hline $\begin{array}{l}\text { Willamette River } \\
\text { Spring chinook spawn in tributaries above } \\
\text { Willamette Falls }\end{array}$ & spring & & 137 \\
\hline Sandy River (upper Sandy) & & & 162 \\
\hline
\end{tabular}


Table 2-2

Fall Chinook Spawning Tributaries between Bonneville and the mouth of the Columbia River. (adapted from: Fulton 1968, Table 5 )

\begin{tabular}{|c|c|c|c|}
\hline River & Ore. & Wash & Km. from Mouth \\
\hline Youngs River & $x$ & & 16 \\
\hline Grays River & & $x$ & 34 \\
\hline Big Creek & $X$ & & 37 \\
\hline Gnat Creek & $x$ & & 39 \\
\hline Elokomin River & & $x$ & 61 \\
\hline Clatskanie River & $x$ & & 80 \\
\hline Mill Creek & & $X$ & 85 \\
\hline Abernathy Creek & & $X$ & 87 \\
\hline $\begin{array}{l}\text { Cowlitz River } \\
\text { (Most productive spawning area } \\
\text { for fall Chinook in Columbia } \\
\text { Basin.) }\end{array}$ & & $x$ & $\begin{array}{l}105 \\
\begin{array}{c}\text { Numerous tribs on } \\
\text { Cowlitz }\end{array}\end{array}$ \\
\hline Kalama River & & $x$ & 121 \\
\hline Lewis River & & $x$ & $\begin{array}{c}137 \\
\text { Numerous tribs }\end{array}$ \\
\hline $\begin{array}{l}\text { Willamette River (small area } \\
\text { below Clackamas River; none in } \\
\text { main stem) }\end{array}$ & $x$ & & 162 \\
\hline Washougal River & & $\mathrm{X}$ & 190 \\
\hline Sandy River & $x$ & & 193 \\
\hline Tanner Creek & $X$ & & 232 \\
\hline Eagle Creek & $X$ & & 235 \\
\hline
\end{tabular}




\begin{tabular}{|c|c|c|c|}
\hline $\begin{array}{r}\text { Tabl } \\
\text { Coho: Spawning Tributaries betwe } \\
\text { Columb } \\
\text { *major coho } \\
\text { (adapted from: Fu }\end{array}$ & $\begin{array}{l}\text { e 2-3 } \\
\text { en Bo } \\
\text { ia Riv } \\
\text { o tribu } \\
\text { Iton } 15\end{array}$ & $\begin{array}{l}\text { aneville } \\
\text { ar. } \\
\text { aries } \\
70 \text {, Tab }\end{array}$ & $d$ the mouth of the \\
\hline River & Ore. & Wash & $\mathrm{Km}$. from Mouth \\
\hline Chinook & & $x$ & 10 \\
\hline Lewis and Clark (lower portions) & $x$ & & 12 \\
\hline Youngs River & $x$ & & 16 \\
\hline Klaskanine River (trib of Youngs R.) & & & 11 \\
\hline Bear Creek (Lower portion) & $x$ & & 30 \\
\hline Grays River & & $x$ & 34 \\
\hline Big Creek & $x$ & & 37 \\
\hline Gnat Creek & $x$ & & 39 \\
\hline Skamokawa Creek & & $x$ & 54 \\
\hline Elokomin River & & $x$ & 61 \\
\hline Clatskanie River & $x$ & & 80 \\
\hline Mill Creek & & $x$ & 85 \\
\hline Abernathy Creek & & $x$ & 87 \\
\hline Germany Creek & & $x$ & 90 \\
\hline $\begin{array}{l}\text { *Cowlitz River (Main stem below } \\
\text { Mayfield Dam; Coweeman River.) }\end{array}$ & & $x$ & 105 \\
\hline Kalama (Lower part) & & $x$ & 121 \\
\hline "Lewis (and east Fork of Lewis R.) & & $x$ & 137 \\
\hline Milton Creek (lower portion) & $x$ & & 144 \\
\hline $\begin{array}{l}\text { Salmon Creek } \\
\text { tributary of Vancouver Lake and } \\
\text { Lake River }\end{array}$ & & $x$ & 150 \\
\hline Washougal River (lower Washougal) & & $x$ & 190 \\
\hline Sandy River & $\bar{x}$ & & 192 \\
\hline Hamilton Creek (lower portion) & & $x$ & 226 \\
\hline Tanner Creek & $\mathrm{x}$ & & 231 \\
\hline Eagle Creek & $x$ & & 234 \\
\hline
\end{tabular}




\section{Table 2-4}

Chum: Spawning Tributaries between Bonneville and the mouth of the Columbia River.

*major chum spawning tributaries

(adapted from: Fulton 1970, Table 5)

\begin{tabular}{|c|c|c|c|}
\hline River & Ore. & Wash & $\mathrm{Km}$ from Mouth \\
\hline Lewis and Clark (lower portions) & $x$ & & 13 \\
\hline Youngs River & $x$ & & 16 \\
\hline Klaskanine River (trib of Youngs R.) & $\mathrm{X}$ & & 11 \\
\hline Bear Creek (Lower portion) & $x$ & & 30 \\
\hline${ }^{*}$ Grays River & & $\mathrm{x}$ & 34 \\
\hline${ }^{* \text { Big Creek }}$ & $\bar{x}$ & & 37 \\
\hline Gnat Creek & $\bar{x}$ & & 39 \\
\hline Skamokawa Creek & . & $\mathrm{X}$ & 54 \\
\hline *Elokomin River & & $\bar{x}$ & 61 \\
\hline Clatskanie River & $x$ & & 80 \\
\hline *Mill Creek & & $x$ & 85 \\
\hline${ }^{*}$ Abernathy Creek & & $x$ & 87 \\
\hline${ }^{*}$ Germany Creek & & $\mathrm{X}$ & 90 \\
\hline Coal Creek & & $\mathrm{X}$ & \\
\hline $\begin{array}{l}\text { Cowlitz River (Main stem below } \\
\text { Mayfield Dam; Coweeman River.) }\end{array}$ & & $x$ & 105 \\
\hline Kalama River (Lower part) & & $x$ & 121 \\
\hline $\begin{array}{l}\text { *Lewis River (and east Fork of Lewis } \\
\text { R.) }\end{array}$ & & $\mathrm{x}$ & 137 \\
\hline *Milton Creek (lower portion) & $x$ & & 144 \\
\hline Salmon Creek & & $x$ & 150 \\
\hline *Washougal (lower Washougal) & & $x$ & 190 \\
\hline "Hardy Creek (lower portion) & & & 229 \\
\hline ॠHamilton Creek (lower portion) & & $\mathrm{x}$ & 226 \\
\hline
\end{tabular}


Table: $2-5$

Steelhead: Spawning Tributaries between Bonneville and the mouth of the Columbia River (adapted from: Fulton 1970:Table 3 )

\begin{tabular}{|c|c|c|c|}
\hline River & Ore. & Wash & $\mathrm{Km}$. from Mouth \\
\hline Lewis and Clark & $\mathrm{x}$ & & 13 \\
\hline Youngs & $\mathrm{X}$ & & 16 \\
\hline Grays River & & $\mathrm{X}$ & 34 \\
\hline Big Creek & $x$ & & 37 \\
\hline Gnat Creek & $x$ & & 39 \\
\hline Skamokawa & & $x$ & 54 \\
\hline Elokomin & & $\mathrm{X}$ & 61 \\
\hline Clatskanie & $\mathrm{x}$ & & 80 \\
\hline Mill Creek & & $\mathrm{X}$ & 85 \\
\hline Abernathy Creek & & $\mathrm{X}$ & 87 \\
\hline Germany Creek & & $\mathrm{X}$ & 90 \\
\hline Cowlitz River & & $\mathrm{X}$ & $\begin{array}{c}105 \\
\text { Numerous tribs }\end{array}$ \\
\hline Kalama River & & $\mathrm{X}$ & 121 \\
\hline Lewis River & & $x$ & 137 Many tribs \\
\hline Milton Creek & $x$ & & 144 \\
\hline Scappose Creek & $x$ & & 146 \\
\hline $\begin{array}{l}\text { Salmon Creek (a tributary of } \\
\text { Vancouver Lake, and Lake River }\end{array}$ & & $x$ & 150 \\
\hline $\begin{array}{l}\text { Willamette River, lower } \\
\text { (tributaries:Tualatin, Clackamas }\end{array}$ & $\mathrm{x}$ & & 162 \\
\hline Willamette River, upper half & $\mathrm{X}$ & & 162 \\
\hline Washougal River & & $x$ & 190 \\
\hline Sandy River & $\mathrm{X}$ & & 193 \\
\hline Hamilton Creek & $x$ & & 226 \\
\hline Eagle Creek & $x$ & & 234 \\
\hline
\end{tabular}


Table: 2-6

Periods of aggregation of resident and migratory fish

\begin{tabular}{|c|c|c|c|}
\hline Fish & Aggregation event & When & Where \\
\hline \multirow[t]{4}{*}{$\begin{array}{l}\text { White } \\
\text { Sturgeon }\end{array}$} & $\begin{array}{l}\text { prey on migrating } \\
\text { eulachon }\end{array}$ & Feb-March & $\begin{array}{l}\text { Major tribs downstream of Sandy R. } \\
\text { gravel substrate }\end{array}$ \\
\hline & $\begin{array}{l}\text { prey on spawned out } \\
\text { salmon \& lamprey }\end{array}$ & spring & $\begin{array}{l}\text { opportunistic, locations where salmon } \\
\text { or lamprey carcasses collect }\end{array}$ \\
\hline & $\begin{array}{l}\text { spawning of sucker, } \\
\text { pike minnow, peamouth }\end{array}$ & spring & spawning areas of prey \\
\hline & $\begin{array}{l}\text { spawn in mainstem of } \\
\text { Columbia River }\end{array}$ & April-July & $\begin{array}{l}\text { areas of high stream flow, cobble } \\
\text { substrate water temperature } 10-18 \mathrm{C}\end{array}$ \\
\hline $\begin{array}{l}\text { Green } \\
\text { Sturgeon }\end{array}$ & unknown & August & $\begin{array}{l}\text { Temporary increase in numbers near } \\
\text { the mouth of the Columbia } R \text {. }\end{array}$ \\
\hline Eulachon & spawning migration & Dec- Feb. & major tributaries of the lower Columbia \\
\hline $\begin{array}{l}\text { Pacific } \\
\text { Herring }\end{array}$ & spawning migration & Jan-Feb & Columbia R. estuary \\
\hline $\begin{array}{l}\text { Starry } \\
\text { Flounder }\end{array}$ & $\begin{array}{l}\text { spawning Columbia } \\
\text { River estuary }\end{array}$ & Feb-April & $\begin{array}{l}\text { estuary, confluenceof tributaries and in } \\
\text { sloughs in water depths of }<45 \text { meters }\end{array}$ \\
\hline Stickleback & normal schooling & Sept-April & mainstem and backwaters of Columbia \\
\hline resident trout & prey on salmon spawn & Fall & $\begin{array}{l}\text { lower tribs at salmon spawning } \\
\text { locations }\end{array}$ \\
\hline $\begin{array}{l}\text { Northern } \\
\text { Pike minnow }\end{array}$ & spawning & May-July & $\begin{array}{l}\text { spawn over gravel substrate with high } \\
\text { flow; confluence of creeks with Col. } \\
\text { and rubble shoreline along Cascades }\end{array}$ \\
\hline \multirow{2}{*}{$\begin{array}{l}\text { Peamouth } \\
\text { chub }\end{array}$} & spawning & May-June & gravel or rubble lake shores or streams \\
\hline & prey on spawn & seasonal & sturgeon and salmon spawning areas \\
\hline \multirow[t]{2}{*}{$\begin{array}{l}\text { Large Scale } \\
\text { Sucker }\end{array}$} & spawning & April-May & $\begin{array}{l}\text { shallows, confluence of tribs \& } \\
\text { shorelines }\end{array}$ \\
\hline & $\begin{array}{l}\text { prey on spawn of } \\
\text { various fish }\end{array}$ & seasonal & $\begin{array}{l}\text { at sturgeon and salmon spawning } \\
\text { locations }\end{array}$ \\
\hline $\begin{array}{l}\text { Pacific } \\
\text { Lamprey }\end{array}$ & spawning migration & April-June & $\begin{array}{l}\text { lower Columbia and Willamette Rivers; } \\
\text { over winter before spawning in spring }\end{array}$ \\
\hline $\begin{array}{l}\text { Spring } \\
\text { chinook }\end{array}$ & spawning migration & Feb-May & $\begin{array}{l}\text { main stem Columbia and Willamette } R \text {. } \\
\text { spawning migration to upper tributaries }\end{array}$ \\
\hline $\begin{array}{l}\text { Summer } \\
\text { Chinook }\end{array}$ & spawning & June-Aug & $\begin{array}{l}\text { main stem of Columbia as fish move to } \\
\text { upper tributaries to spawn }\end{array}$ \\
\hline Fall Chinook & spawning migration & $\begin{array}{l}\text { mid-Aug.- } \\
\text { Oct }\end{array}$ & $\begin{array}{l}\text { main stem and tributaries of lower } \\
\text { Columbia }\end{array}$ \\
\hline Sockeye & migration & May-Aug & intercept during spawning migration \\
\hline Chum & spawning migration & Oct.-Dec. & main stem and tribs of Columbia \\
\hline Coho salmon & spawning migration & $\begin{array}{l}\text { late Aug. - } \\
\text { mid Nov. }\end{array}$ & $\begin{array}{l}\text { main stem and tributaries of coastal } \\
\text { and lower Columbia River }\end{array}$ \\
\hline \multirow[t]{2}{*}{ Steelhead } & spawning local & winter & stream/spawing locations in study area \\
\hline & spawning migration & summer & only in main stem of Columbia \\
\hline
\end{tabular}



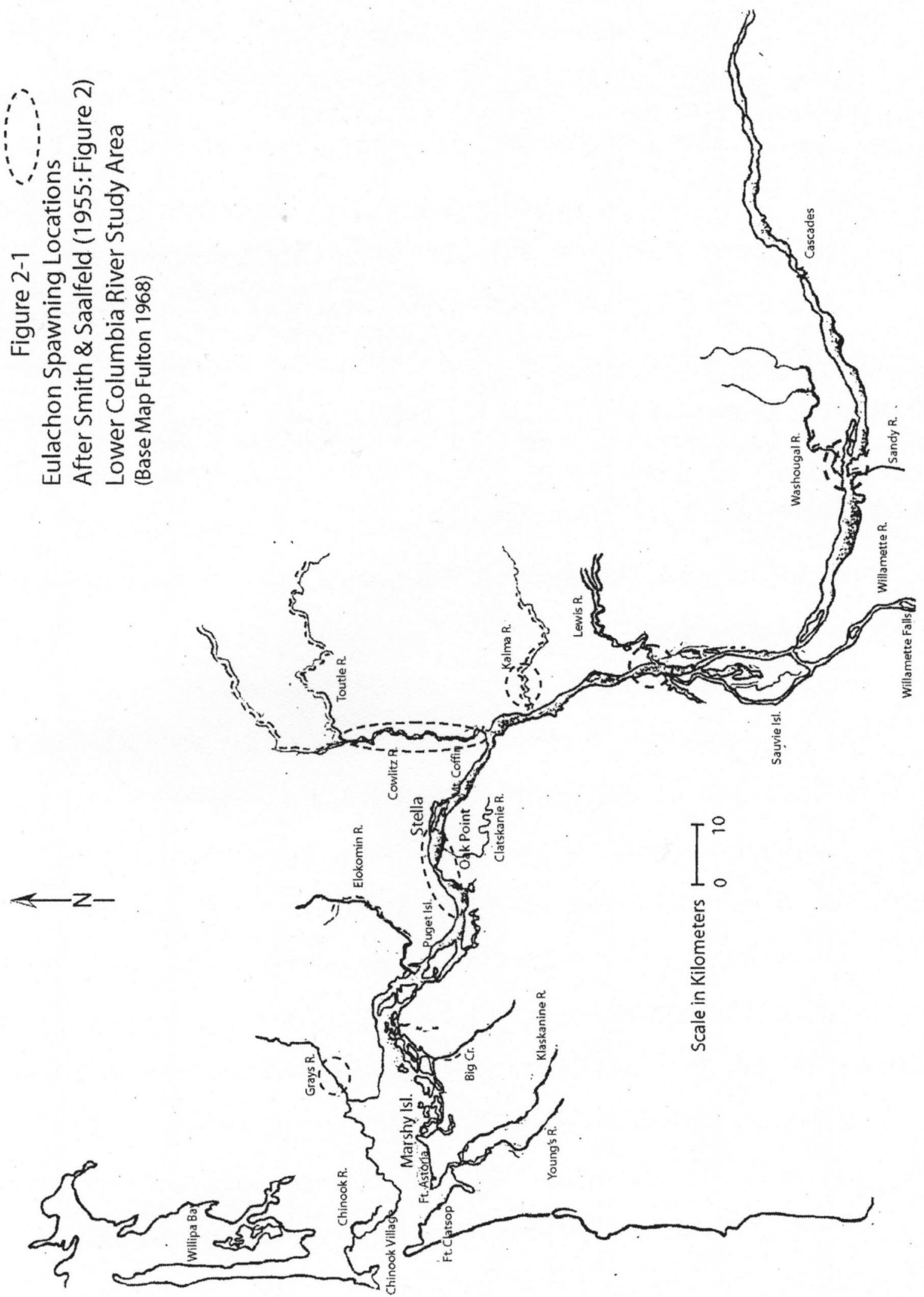


\section{CHAPTER 3}

\section{AN ANNOTATED ACCOUNT OF THE HISTORIC FISHERIES OF THE LOWER COLUMBIA RIVER FROM 1792-1850}

In this chapter I systematically organize and critically review historic documentation on the fisheries of the lower Columbia River from 1792 through the 1850's. I use this information to address questions on gear, fish selection, and place. Place is critical to my inquiry: I look for details as specific and local as each record provides.

There is a strong precedent for the use of historic documents to provide cultural information on native economies and social relationships. The historic record is the primary resource for information used to reconstruct the social organization and history of the lower Columbia River Indians (Ray 1938; Hadja 1984; Boyd and Hadja 1987; Silverstein 1990), especially given the extent of population loss at contact. Historic accounts provide baseline information used to reconstruct local economies and by comparing local economies, the ethnographic pattern of the Northwest Coast (see Mitchell and Donald 1988). Archaeologists use the historic record as a source of information providing analogs to define settlement patterns, the prehistoric use of fish and other fauna (Saleeby 1983; Saleeby and Pettigrew 1983) and to identify fishing gear from artifacts recovered in archaeological contexts (Pettigrew 1977; Dunnell and Campbell 1977; Minor 1983).

The historic record contains significantly more information and more detail about the economic activity of fishing than has been used in previous 
studies. Fisheries were a critical part of the economy providing resources that sustained people throughout the year. My intent in this chapter is to develop information using the historic record to address a set of questions involving fish selection, procurement and use. Briefly, what fish were used as resources? When were they taken? How were they used? And, did the places they were taken influence the kind of gear used?

New England merchant trader Captain Robert Gray (Howay 1941) of the Columbia Rediviva and Captain George Vancouver (Vancouver 1792 (1926)) leading a British expedition are the first reported accounts of sailing vessels crossing over the Columbia River bar and exploring upstream. Gray's first mate, Boit, made the first record of the Chinook Indians of Baker Bay in May 1792. The expedition traded for fresh salmon and furs.

Using information provided by Captain Grey, Lt. Broughton of Captain Vancouver's staff entered the Columbia River in October of 1792. Broughton mapped the Columbia River shoreline from the mouth to a point just above the confluence of the Columbia and Willamette Rivers. The map recorded village locations along the shoreline, but did not discuss fish or fishing. As neither of these accounts provide additional information useful for my study, I do not reference them any further.

The records I cite are the accounts of explorers, fur traders and settlers. My primary resources, listed chronologically, are: Lewis and Clark (Moulton $1990,1991,1995,1996)$ journals; Gass, a sergeant in the Lewis and Clark expedition who kept a journal; the accounts of the Pacific Fur Company 18101813, including the journals of Gabriel Franchere (Franchere 1967), and Robert Stuart (Rollins 1995); and the administrative record of Fort Astoria kept 
primarily by Duncan McDougall (Jones 1999), but with a few entries by an unnamed clerk; Alexander Henry, Northwest Fur Company (Coues 1897; Gough 1992); the naturalist John Townsend (1978); botanist, David Douglas (Wilks 1959); the U. S. Exploring Expedition's record written by Charles Wilkes (1845); and George Swan's account of his ca. 1850's stay at the mouth of the Columbia River.

I have organized the information in these accounts in the following manner:

I list the fish as they are reported providing a table for each account, noting common name, probable genus and species, and comments pertinent to their identification. If an editor of an account has identified the fish, I provide that information. When the species of fish is not evident, I provide a probable identification and note my reason for species assignment.

I discuss the places and general locations of the fisheries and when they occurred. I note particular places, typical environments or more general information depending on the comments provided in the various accounts.

For each account I highlight the gear used to take fish. I list types in a table and note any additional information the record includes, such as manufacturing of that gear or variation in the type.

I believe the information I develop will be useful for evaluating archaeological data. My study will provide the general environmental context and in some cases the specific places of the fisheries; notes on gear and where it was used; and information about the species of fish identified.

I do not consider how the historic period fisheries relate to the fisheries of the prehistoric periods. This is a question of a different order requiring a 
detailed discussion of what is known of archaeological fisheries from site investigations. The scale of the fisheries, how much they returned, how intensively the study area was fished, and perhaps the diversity of fish taken, may have differed from the historic ones. The demand for resources must have been greater before contact with American Traders and European explorers. Prior to Captain Gray and Vancouver, 1792, epidemic diseases introduced indirectly to the study area decimated native populations. In 1805 , Lewis and Clark reported burial canoes and abandoned villages along the west shoreline of Youngs Bay, reminders of the epidemic. Epidemics struck again in the 1830's taking, perhaps, $75 \%$ of the people in Sauvie Island vicinity (Cook 1955; Boyd 1975; 1999). The epidemics greatly impacted all lifeways, including the fisheries.

The information I organize and discuss may also be qualified by the sources who report it. Much of the information comes from trade records. These are accounts of the purchase of fish from Indians for the consumption of fur trading crews. What fur trading crew needed were large quantities of fish, both fresh and preserved, to support their enterprises. Thus, the fish selected may be mostly limited to what could be taken in large quantities, what the Indians could preserved and to a degree, what the fur trading crews would eat. Thus, some sort of preference for certain types of fish and what the Indians were willing to provide may have limited fish to certain kinds.

\section{The Corps of Discovery: November 1805-April 1806}

\section{Meriwether Lewis, William Clark and Patrick Gass}

Lewis and Clark, commanding the Corps of Discovery, set out to explore portions of the midwest acquired as part of the Louisiana Purchase 
and then to find a route to the Pacific Ocean. By the time the Corps entered the study area they had nearly completed the westward portion of their journey.

The expedition was tasked by President Thomas Jefferson to acquire information on the lifeways and practices of the native people they encountered. Their observations are structured by the requirement to make a record of the "ordinary occupations in... fishing...[and].... the animals of the country" (Thwaites 1969: Appendix XVIII; President Thomas Jefferson's instructions to Lewis). Lewis and Clark's journal entries during their winter stay at the mouth of the Columbia River recorded their trade for subsistence, mostly fish, with the Indians and observations on the gear the Indians use to take fish.

The expedition entered the study area on November 2, 1805 passing through the Cascades of the Columbia River at the upstream end of Hamilton Island. Near the end of November the expedition arrived at the mouth of the Columbia River and picked the site of their winter encampment. By the middle of December they had completed building their winter residence, Fort Clatsop.

Between 1792, when Gray and Vancouver crossed into the Columbia River, and Lewis and Clark's arrival in the winter of 1805, the Columbia River estuary and Baker Bay became a trading place and anchorage for commercial maritime traffic. The Columbia River anchorage in Baker Bay was named Halley's Bay by Lewis and Clark, acknowledging the American trader Halley, a favorite of the local Indians (Moulton 1990:50). Lewis and Clark noted evidence of commercial traffic: Chinook Villagers of Baker Bay had European clothing and trade goods; some of the women were tattooed with sailor's names; and many of the Chinooks knew a few English expletives. Passage 
on a vessel engaged in the commercial fur trade had also been offered as an option for Lewis and Clark's return to the east coast and New England.

\section{Fish types noted}

Lewis and Clark discussed 7 different kinds of fish found within the study area (Table 3-1). (Lewis and Clark also noted the taking of cetaceans, whale and porpoise, marine mammals which are not discussed further.) $A$ few were reported earlier in other places. Moulton (1990) and Thwaites (1969) who edited the Journals, and Cutright (1969) who summarized the natural historical observations of the expedition, assigned species names to many of the fish. Reviewers have left some fish unassigned, such as those Lewis and Clark referred to as "small fish" and the "fish with green flesh".

One of the expedition's contributions (not only because they were the first to spend a number of months in the area, but also because they were required to document aspects of the economy) are the first descriptions of fish. The names they used to describe fish are important because in some cases these same names are used in subsequent accounts providing a means of comparing records over time. Similarly named and mapped fishing locations can be compared between historic accounts. If Lewis and Clark provide a general description of an area where fishing for particular fish occurred, then adding detail from subsequent accounts, especially with more precise locations, provide supporting information. Consistency over time reenforces information, whether it is metric, a qualitative evaluation of a fish, or place names.

Sturgeon. Moulton (1990) notes the problems of fish identification questioning which sturgeon, white or green, was noted by Clark on the beach 
near Cape Disappointment (Moulton 1990:70). In this case Moulton suggests that Clark exaggerated the size of the fish at 10 feet, proposing that the fish was a green sturgeon. If the fish reported was under 7 feet, an improbable error of 3 feet on Clark's part, then as Butler (2004:445) noted it may be either a white or green sturgeon. Adult white sturgeon may exceed the maximum length of green sturgeon, usually placed at 7 feet [ 2 meters]. I feel that there is no reason to question Clark's estimate of this fish's length. Size can distinguish white from green sturgeon and a sturgeon greater than 7 feet in length is a white sturgeon.

Many of the records in the journal and related documents frequently describe sturgeon as Gass does (one of the members of the expedition), as "large" (Moulton 1995:201;15) which by itself does not help distinguish white from green sturgeon without additional information. However, white sturgeon is more common in the Columbia River and a large resident population of this species are present, while green sturgeon is rare. Therefore, it is more likely that white sturgeon make up the majority of sturgeon taken in the Columbia River.

Lewis noted that the Clatsop Chief, Comowooll, had brought a sturgeon that was the "good of its kind" (Moulton 1990:344). This remark was made regarding the sturgeon's edibility; it also suggests awareness of another species of sturgeon, one that was not as desirable. As a food resource, the preference for white over green sturgeon is commonly noted in fishery handbooks and will be mentioned in subsequent accounts (Wydoski and Whitney 2003:41).

Flatfish. Moulton (1990:63) identified the flatfish recorded by Lewis and 
Clark as most likely the starry flounder. Gass reported that flounder was scavenged from the shoreline of Baker Bay where it had been tossed on a beach during a storm (Moulton 1995:175). The starry flounder is abundant in estuaries (Eschmeyer et al. 1983:291-292; Monaco et al. 1990: Table 3). It is also tolerant of freshwater with juvenile fish found throughout the lower Columbia up to Vancouver, Washington. However, the expedition's description of flatfish is poorly developed and species assignment is inconclusive.

Coho. Lewis and Clark traded for and caught a fish they called "red charr" (Moulton 1990:40-41). The first report of red charr was made on November 11, 1805 in a trade with the Indians near the middle of the estuary. A description of red charr including coloration and physical characteristics is part of the Journal entries for March 13, 1806 which summarize the expedition's natural history notes. The choice of name for this fish is unique to Lewis and Clark. This fish is not a member of the charr genus, as its scales are large and the scales of charr are very small. This fish is not a sockeye, as has been suggested because sockeye are not present in November, and all of the sockeye spawning habitat is located hundreds of kilometers above the study area (see Butler 2004).

The red body color of charr suggests coho. Spawning coho, especially males, are red over most of their body. Chum may also have a red coloration, but the color is not uniform, rather it is broken-up in streaks, a variegated pattern, not one tending to a uniform color.

Lewis notes that the teeth of this fish are "neither as large nor so numerous as those of the salmon" (Moulton 1990:411). Absence of large 
teeth eliminates chum as a possible choice for the red charr. Chum have large exaggerated teeth, a feature that may be responsible for one of its common names, dog salmon (Behnke 2002:51-52). In contrast the coho's teeth are much smaller.

The only remark, as Butler (2004) noted, that is inconsistent with identifying this fish as coho is the report of spots. Lewis commented that "none of them [red charr] are variegated with the dark spots which make the body of the other" (Moulton 1990:411). Butler (2004:443) argues that this descriptive note eliminates or makes questionable identifying this fish as a coho because the coho does have a few spots. However, I think Lewis was noting that the common salmon was heavily marked, variegated, with dark markings, while the [red charr] was not. I do not think Lewis' comment eliminates the possibility of a few spots.

I believe the red charr is a coho. Coho is the only fish whose primary body color is red at spawning. The chum's body color is streaked. The coho has small teeth, especially notable when compared to the exaggerated teeth of the chum. Body color and teeth point to coho as the fish Lewis called the red charr. The question of no spots as opposed to heavily variegated cannot be simply resolved, but may not be as important to the argument given color and tooth size.

Salmon trout and white salmon trout were two different fish to Lewis and Clark. Salmon trout were first noted, October 24, 1805 (Moulton 1990:412413) in the pool at the base of Celilo Falls. Following this remark the party mentions salmon trout three more times, first in early November as part of the trade and as a fish taken by members of the expedition. In the description of 
salmon trout they note that it has dark spots on its body similar to salmon but which are not found on red charr. The teeth are not pronounced which eliminates chum salmon. Salmon trout are probably steelhead.

White salmon trout are reported in March 1806, in the creeks around Ft. Clatsop, at the Cascades on April 1806 and while visiting with the Wallahallahs on the middle Columbia on April 27,1806 . This fish is probably not spring chinook because March is too early for chinook and at 10 pounds [4.5 kg] it would be a small chinook. White salmon trout are not coho, because coho are not present in the spring. White salmon trout are probably winter or spring steelhead.

Lewis and Clark reported the taking of small fish in the spring and summer with a scoop net but did not discuss these fish any further. Eulachon would be an obvious choice for small fish taken in the lower Columbia River, but the run is almost over by spring. Moreover, they referred to eulachon as "Anchovies", and had no reason to just call them small fish (Moulton 1990:401). It is possible that other small fish were taken but, there is no description in their accounts as a point of reference. Comments about summer are not pertinent as the expedition left the study area in late March reaching the Snake River in April 1806.

\section{Preserved fish}

On November 2, 1805 Lewis and Clark reported a canoe load of pounded salmon on its way downstream having passed through the rapids at the Cascades. On the same day they noted a canoe load of dried salmon downstream of the Cascades (Moulton 1990:7-8). These fish had been dried and the pounded salmon produced upstream of the Cascades. 
Lewis and Clark reported the procedure for smoke curing eulachon in village houses in a March 4, 1806 entry,

...the natives run a small stick through their gills and hang them in the smoke of their lodges, or kindle a small fire under them for the purposes of drying them. they need no previous preparation of guting $\& c$ and will cure in 24 hours...(Moulton 1990:378).

The expedition did not provide notes on the smoke curing of salmon.

\section{Fishing locations}

Lewis and Clark mapped locations and added additional remarks on the general locations of Indian fisheries (Table 3-2). General locations included estimates of the distances of fishing places upstream from Fort Clatsop where expedition members were dispatched to trade for fish.

Clark reported that both the expedition and Indians scavenged fish tossed up on the beach during winter storms (Moulton 1990:410).

Lewis and Clark were the first to describe aspects of the white sturgeon fishery. During the winter, from February through March, they traded for fresh sturgeon. Sturgeon fishing was carried out by individuals and small parties of up to 10 (for example Moulton 1991:12). They defined the limits of the sturgeon fishery on their return upstream in late March-early April. They mapped the location of sturgeon fishing camps along the Oregon shoreline of the Columbia River (Moulton 1990;1991). The first sturgeon fishing camp was reported on Puget Island (CRM 40) with other camps noted as far upstream as Sauvie Island.

The party discovered that there was no sturgeon fishing above Sauvie Island on the Columbia River. How far upriver the sturgeon fishery extended was put to a group of Indians, April 1, 1806 coming downstream from the 
Cascades (Moulton 1991:49). The Indians confirmed that there was no sturgeon fishery upstream of the confluence of the Willamette with the Columbia River. In fact, they were coming downstream as food was in short supply upriver.

The same informants reported that spring chinook had not appeared at the Cascades (Moulton 1991:49). This was disappointing news to Lewis and Clark who were hoping to use the migrating spring chinook as a dependable source of food on this leg of their return trip.

\section{Fishing gear}

Lewis and Clark provide the first account of fishing gear used by the lower Columbia River Indians (Table 3-3). Fishing gear is mentioned as part of daily entries and in summary statements dated January 9, 1806 and March 13, 1806. The summaries itemized fishing equipment and sometime elaborated on its construction or discussed how gear was used. Their entries and summaries assume previous knowledge of fishing gear. For example, they referred to a large rectangular net, as a "common streight net" (Moulton 1990:211-212). Citing familiar gear certainly drew attention to a type, but it also reduced descriptive detail on the gear the Indians actually used.

Hook. Lewis and Clark provide the only record of a traditional two piece acute angle hook (Figure 3-1). An informant from the lower river reported that,

...before the whites visited them they made hooks of bone and other substances formed in the following manner [Figure 1] A C, and C. B. are two small pieces of bone about the size of a strong twine, these are flattened and leveled off of their extremities near C. where they are firmly attached together with sinues and covered with rosin. C A. is reduced to a sharp point at $A$ where it is also bent a little; $C B$. is attached to the line, for about half it's length at the upper extremity $B$. the while forming two sides of an accute angled triangle 
(Moulton1990:212).

The drawing also shows a line attached to the hook. Their record did not include a scale, so there is no information on hook size or whether this type includes a variety of sizes. Nor is there information on what bait was used, or whether or not the line was weighted and if so, what the weight was made of. Finally, no reference was made regarding the fish taken with this hook.

The acute angle hook was gear of the recent past, before 1805. Lewis and Clark claimed that steel hooks, obtained in trade, had completely replaced the traditional two piece acute angle bone hook on the lower Columbia River. The traditional hook was still used on the "upper parts of the Columbia River to catch fish in Deep places" (Moulton 1990:211), although specific locations and the species of fish taken were not reported.

Line."[S]lik-grass or white cedar bark" were the materials used for fishing line and nets (Moulton 1990:212). The method of line manufacture is not discussed nor whether it was made in different sizes for fishing lines or net cordage. Hook and line fishing was reported as a method used to take sturgeon.

Gig [Fish Spear]. The gig was first reported while the expedition was with the Nez Perce in southern Idaho. The Nez Perce used the gig to take salmon, although the description of the gig used by the Nez Perce is not clear. Lewis refers to it in his description of the gig used by the Indians in the study area. The Clatsops took salmon and other fish in streams and creeks in the vicinity of Fort Clatsop with a two pronged gig (Moulton 1990:210).

Nets. The net fishery consisted of "the common streight net, the 
scooping or diping net with a long handle" (Moulton 1990:212). Though the account notes "different lengths and depths", no reference was made of mesh sizes nor did they discuss net weights or floats.

The "skimming or scooping net [was used to take] small fish in the spring and summer season" (Moulton 1990:212). The scooping net was so familiar to Lewis and Clark that they referenced it as a type without any further comment. The only feature of the scoop net described by Lewis and Clark was the net's "long pole" handle. Scooping nets were part of the fishing gear in a Clatsop chief's canoe which was loaded with a catch of eulachon (Moulton 1990:211; 346).

\section{Pacific Fur Company, Northwest Fur Company, 1811-1814}

Duncan McDougall, Gabriel Franchere and Robert Stuart were part of the Pacific Fur Company's sea party arriving on the vessel Tonquin at the Columbia River mouth in April 1811. McDougall and Stuart were proprietors of the Company and Franchere was a clerk. McDougall spent most of his tenure at Fort Astoria, Oregon (within the present town of Astoria). Stuart's time was divided between the lower and the upper Columbia River basin where he explored and assessed the potential of both areas to support the fur trade. Franchere spent his time on the lower Columbia doing a variety of tasks, including supplying the post with fish.

\section{Duncan McDougall 1811-1814}

As one of the four proprietors of the Pacific Fur Company, Duncan McDougall directed the operation of Fort Astoria between April 1811 and its sale to the Northwest Fur Company in 1813. He (and an aide) kept the "Headquarters Log", the administrative record of post activities. The Log 
highlights two years of daily activities at the post including McDougall's assignments of clerks and employees to various tasks such as, staffing the upper Columbia River and the Willamette River trading posts and directing subsistence procurement efforts. Under McDougall's direction, Gabriel Franchere managed the company's sturgeon fishery near Oak Point (CRM 50 to 51) and traded with the local Indians for sturgeon. McDougall also recorded his trade with the Columbia River Indians for sturgeon, eulachon, and different kinds of salmon.

McDougall's account is a bookkeeper's record of trade. He reports the date, fish, and cost in trade goods and frequently names the Indian fisher or the village leader who made the trade. Many of McDougall's entries include a count of the number of fish traded. When he did not provide a count, he recorded his purchase using two qualifiers, "some" or "few" and when the trade was particularly robust he writes, "considerable quantity" or "great numbers".

The fish trade involves more than the mere availability of fish, there is also the Indian's willingness to sell or trade. The Chinooks probably attended to their own economic interests first, acquiring their own stores of fish which may have influenced the initiation of any trade. There are periods when fish are present but McDougall cannot induce a trade for fish no matter what he offers (Jones 1999:144,149). On some occasions the price is too high and McDougall will not trade, although he has an ongoing and sometimes pressing need to obtain food to support his staff and field crews. In one instance two important trading partners would not trade their first catch with McDougall because there were ceremonies to perform and they were 
concerned that proper methods of preparing the first fish were observed (Jones 1999:55). The trade started shortly after the ceremonies were completed.

Much of McDougall's trade approximates the seasonal availability of fish because most of the daily trade was for fresh fish (Table 3-4). The number of trades for preserved fish was fewer, although from this trade he acquired the stores of food that supported his crews for periods when fresh fish were unavailable. Sturgeon, eulachon and salmonids constitute the bulk of the trade.

During the winter sturgeon fishery, McDougall reported a trade in eulachon. He also refers to a trade in small fish which probably are eulachon because these trades occurred during March (Jones 1999:82) and near the end of May (Jones 1999:93). Late May is somewhat beyond the period of the eulachon fishery; but there is no clear reference to or a description of another species. There is a possibility that Pacific herring, C. harengus, were taken in the late spring. Pacific herring spawned along both shores of the Columbia River, from the mouth to CRM 40 (Lassuy 1989: Figure 2).

\section{Fish types noted}

McDougall's accounts provide a more precise measure of the seasonal periods when salmon and sturgeon were available, fresh as well as preserved, than other accounts. Because McDougall's record is distinctive, I discuss each fish first, as fresh fish, and then if it was preserved for deferred use under a heading of preserved fish.

Sturgeon. I compiled the sturgeon trade by month using the entries that report the numbers of fish traded (Figure 3-2). I did not use the 1811 accounts 
because the trade was characterized by adjectives, such as many, few, or great numbers rather than the actual quantity traded. The information illustrated is based on when the fish were brought to the post and in one case a settlement with one or more of McDougall's Indian trading partners who supplied the base with fish. The 1813 trade was also more robust probably because McDougall needed more supplies and his relationship with the Indians had developed.

The resident sturgeon fishery probably targeted only white sturgeon. McDougall's trade record demonstrates a sustained trade for large quantities of sturgeon from February to April; a shorter summer fishery in August; and an intermittent trade for sturgeon, single fish or maybe two or three over most of the rest of the year. Sturgeon taken in the winter were eaten as fresh fish and a portion of the catch preserved. Smoke cured sturgeon were traded through early spring (Jones 1999:83).

Eulachon. The winter sturgeon trade was preceded by the trade for eulachon. Large quantities of eulachon were traded from February through the end of March. McDougall earliest trade for eulachon was on February 2, 1812 (Jones 1999:70). Eulachon were not counted individually, but the amounts traded were reported as "canoe loads" (Jones 1999:73), by the "bushel" (Jones 1999:72), "plenty" (Jones 1999:155) or as a "considerable quantity" (Jones 1999:156). As the season progressed, smoke cured eulachon entered the trade in March with the largest quantities traded in April.

Salmon Trout. McDougall's recorded two trades for salmon trout, 24 were acquired on May 5, 1812 (Jones 1999:87) and 50 on May 9, 1813 (Jones 1999:179). Salmon trout were probably steelhead, although McDougall 
provides no description of the fish. By eliminating unlikely candidates, I believe McDougall's salmon trout can be tentatively identified. The trade for salmon trout is in May. At this time, spring chinook or steelhead might be present, although May is early for spring chinook. McDougall was familiar with chinook salmon having traded for these fish for two years and therefore was unlikely to confuse salmon trout with chinook salmon. Salmon trout are probably not spring chinook. The only other anadromous salmonid present at this time would have been steelhead. By calling this fish salmon trout, McDougall draws attention to the relationship between resident species of $O$. mykiss and its anadromous form, steelhead. The timing, lack of alternate anadromous fish to choose from, and the similarity to resident trout, suggests that steelhead is most likely, salmon trout.

Salmon trout were all consumed as fresh fish. Monaco et al. (1990:148) report that adult steelhead weigh between 2 and $5 \mathrm{~kg}$, thus fifty steelhead could provide 100 to $250 \mathrm{~kg}$ of fish. While the return in food weight is speculative, if the salmon trout is steelhead these 24 or 50 fish would have made a substantial contribution to the daily diet. A quantity in this amount was important to McDougall whose crew were on short rations late in spring, but it is also important to note that these fish were taken within a very limited period, and were not part of the trade after the salmon runs appeared.

Chinook salmon. The trade in salmon is strongly defined by season. It is clear from the seasonal timing and the locations that the salmonid dominating the trade is chinook salmon. These fish included spring, summer and fall chinook. By June fresh spring chinook were traded in large quantities in contrast to the few that were traded in May. Fresh chinook were traded 
through early August.

Fall chinook entered the trade in October. These fish are caught from streams within the study area such as, those near the Chinook Village (Jones 1999:59); the Cathlamet Village perhaps from Big and Bear Creek (Jones 1999:55); and the Oak Point vicinity. Taking these fish in local streams is consistent with the fact that only fall chinook spawn within the study area, spring and summer chinook spawn outside of the study area. Fall chinook was taken in sufficient quantities that portions of the catch were preserved.

Based on the trade record, human predation on chinook salmon in the study area produced resources in varying quantities over a 9 month period (Figure 3-3). The first fish were taken in May with the largest catch taken in July. A small peak occurred in November with fewer fish taken into December. The time frames described are consistent with the run of chinook salmon in the Columbia River. The spring run initiates the fishery providing the first fish of the year; the summer dominates the fisheries, providing the largest catch from the mainstem; and the fall fishery, the fishery for fall chinook that spawned in the tributaries of the Columbia River within the study area.

Chum salmon. It is not clear how many chum salmon were traded, these fish were noted but not counted. In late February 1813, McDougall traded for "the worst kind of smoked Salmon" (Jones 1999:158). These were purchased out of necessity and were not a favored food item at the post. Fall chinook salmon are not present in February, but some chum may still be entering the river.

\section{Preserved fish}

In order to support his staff McDougall traded for large quantities of 
preserved fish. His record, with varying degrees of detail, identifies the type of fish, method of preserving, quantity and the timing of the trade.

White sturgeon. Besides fresh fish, part of McDougall's trade was for smoke cured sturgeon. Sturgeon was sliced into pieces, smoke cured and traded in bales. A bale contained 10 to 12 pieces of smoke cured sturgeon. On April 19, 1812 McDougall traded for 10 or 12 bales of dried sturgeon, about 120 to 144 pieces and commented that he had nearly a month's supply of smoke cured sturgeon which he hoped would last until the arrival of salmon in May (Jones 1999:82).

In the following year on April 16, 1813 he traded for 110 pieces of smoked cured sturgeon (Jones 1999:174). All of the smoke cured sturgeon was acquired in April, suggesting that this product was produced from fish taken in the winter sturgeon fishery.

Eulachon. Eulachon was smoke cured and strung on six foot lengths of cord and traded by the fathom, a nautical measurement of 6 feet. On a busy trading day, April 19, 1813, McDougall traded for "180 fathoms of dried Uthlecans" (Jones 1999: 174). He traded for at least 353 fathoms of eulachon in 1813 and mentioned additional trades without reporting the quantity. There are no reports in the documents I cite of eulachon oil being traded or produced in the study area, as it was in other parts of the Northwest Coast (see Bryam and Lewis 2001).

Chinook salmon. Spring, summer and fall chinook salmon were all preserved providing storable food (Figure 3-4). The method of preserving and the place where salmon was processed varied with the stock. On May 9, 1813, McDougall acquired a very small quantity of partially dried spring 
chinook that he states came from the Cascades (Jones 1999:178). That small quantity is the earliest report of preserved fish, and one of the few for spring chinook.

In July the trade in dried salmon increased dramatically and peaked in August. As the chinook summer fishery ended dried chinook entered the trade. Dried chinook came from outside the study area. The primary distribution point for dried fish was the Cascades. McDougall dispatched crews to the Cascades to trade for dried fish (Jones 1999:188, Indians trading dried salmon to McDougall, also obtained dried fish at the Cascades (Jones 1999:178,188). Although the Cascades was a trading place, McDougall's record is about the movement of dried fish downstream. There are no comments in his record to indicate that salmon was dried at the Cascades.

In August and September fresh chinook from the fall run entered the trade. By October, smoke cured fall chinook was available from many local sources (Jones 1999: 48, 57, 63,135,161 and 163). Though the earliest trades for smoke cured salmon were on September 21 (Jones 1999:48) and 29, 1811 (Jones 1999: 61) the largest quantity traded, 500, was in November 13, 1812 (Jones 1999:135) from Comcomly, a Chinook Village chief. Unlike dried chinook which were traded to McDougall by a few Indians (as well as obtained by his own crews) the smoke cured chinook is traded by many named and unnamed Indians. The variation in suppliers and the presence of fall chinook in local streams suggests that smoke cured fall chinook was a local product traded by many individuals and not monopolized by a few Indian traders. In addition, McDougall's record of the fall chinook trade does not include any references to the Cascades as a source, again suggesting that 
smoke cured chinook came from the lower Columbia River.

McDougall's record suggests a linkage between chinook salmon runs and preservation methods (Figure 3-4). Chinook taken in June, July and August were the fish used to produce dried salmon. There are no references that the June, July or August fish were dried in the study area, only that they were traded from upstream sources, primarily from the Cascades. In October, fresh fall chinook are traded and in November smoke cured fish enters the trade. McDougall remarked that fall chinook came from local streams and some of his staff fished these streams with local Indians (Jones 1999:56, 58, 60). The fall run taken in local streams was the source of smoke cured salmon produced in the study area.

Both dried and smoke cured chinook, because they are storable foods, have an extended shelf life and were traded months after they were processed. Small quantities of both were traded as late as March before the salmon runs started.

McDougall reports a single trade for a small quantity of "pounded fish" brought to the post by an Oak Point Village headman on November 6, 1811 (Jones 1999:56). There is no record of where pounded fish was produced. Pounded fish is thought to come from The Dalles where dried fish was ground and packed into bundles according to Lewis and Clark (Moulton 1995:165; Schalk 1986:11).

\section{Fishing locations}

McDougall did not observe fishing first hand, he spent most of his time at Fort Astoria, but he knew place names from the remarks of his field staff or from the Indians who came to trade at Fort Astoria. McDougall names six 
places where salmon were taken and two for sturgeon (Table 3-5). McDougall also knew about the arrival of fish at certain locations from his trading partners, whom he identified by name or by village. Based on this information, he dispatched crews to places his trading partners told him had fish.

McDougall identifies two locations where fresh salmon were first caught. On April 24, 1812, the first chinook salmon brought to the post came from Willamette Falls, after McDougall dispatched a crew to "purchase salmon which they begin to catch at that place" (Jones 1999:85). Fresh salmon from the Cascades were brought to the post on May 5, 1813 (Jones 1999:178).

During the fall, McDougall reports salmon taken in the creeks around Cathlamet Village which was located near Big Creek on the south shore of the Columbia River.

McDougall does not discuss the location of the winter sturgeon fishery, only noting that most of these fish come from Oak Point, which was also the company's field camp and a collection point for fish traded along the river. During August, McDougall and others reported the expanding settlement and increased numbers of Indians around the Chinook Village at Baker Bay. The notable increase in the number of visitors at the Chinook Village marked the beginning of the summer sturgeon fishery.

\section{Fishing gear}

McDougall's perspective on fishing gear includes references to trade goods and gear the Indians manufactured (Table 3-6). Under McDougall's direction the company manufactured gear for trade, supported trading partners by loaning gear, and copied gear the Indians used to catch fish. 
Sturgeon hooks were manufactured by the post's blacksmiths for the company's fishery and as trade items for Indian fishers but were not described. He also provided Comcomly, one of the Chinook Village Headmen, with a "Skein of holland Twine" to finish a net (Jones 1999:153).

His crew procured raw materials, poles, and copied the scoop nets the Indians used (Jones 1999:56). Based on his informant's comments, McDougall states that scoop nets were used on small streams to take salmon around Cathlamet Village.

\section{Gabriel Franchere 1811-1814}

Franchere's account includes his employment at Fort Astoria with the Pacific Fur Company from 1811-1813 and with the Northwest Fur Company from 1813 to 1815 after they purchased Fort Astoria. He wrote his account after he left employment with the Northwest Fur Company and returned to Montreal, Canada. His journal reports his specific assignments by the date and more general matters by the month. His record is not a daily account of his experience at Fort Astoria.

\section{Fish types noted}

One of Franchere's major duties was directing the company's winter sturgeon fishery and winter trade with the Indians for sturgeon (Jones 1999:153). He also discusses other fish taken in the study area (Table 3-7).

Salmon. Franchere recognized two different salmon. He distinguishes between the two based on the palatability of the two forms, as well as noting the differences in their appearance. The salmon caught in July are fatty and rich eating. In contrast those in October-November were a "...different species [of salmon] from the one in July... [it] is very lean and dry, with a whitish color 
and an insipid flavor. It also differs from the other in its shape, having very long teeth and a hooked nose like the beak of a parrot" (Franchere 1967:108). The "fatty and rich eating" salmon are chinook salmon and July is the peak of their migration in the study area. These fish are in prime shape as referenced by the quality and richness of their flesh.

The October-November, lean and dry fish with white flesh, very long teeth and exaggerated kype, the "hooked nose", are characteristics of the chum salmon. Thus, the October-November salmon of a different species was chum. Franchere does not mention fall chinook or coho.

Mullet. Franchere does not describe the mullet except by noting that it is a small fish. According to Franchere the Indians baited their sturgeon hooks with a "little fish called mullet" (Franchere 1967:112). This is probably not the marine species Mugil cephalus, commonly called mullet. This fish is found in the ocean and brackish water but is rare north of San Francisco, California (Eschmeyer et al. 1983:234). The common name "mullet" is used in the midwest and Great Lakes for sucker, (michigan.gov 2006; note also Hunn's 1995:155 remark that Lewis and Clark's called the sucker, C. macrocheilus, mullet). It is possible that the little fish Franchere called mullet is a species of

Catostomus. However as previously noted, C. macrocheilus can weigh $3.2 \mathrm{~kg}$ and reach a length of $60 \mathrm{~cm}$ as an adult, not a small fish. Given the comment that the mullet is a small fish, it may be that Franchere called some freshwater resident minnow, mullet.

\section{Fishing locations}

Franchere's first hand experience was with the sturgeon fishery. His record of fishery locations reflects his participation in the fisheries (Table 3-8). 
In the winter of $1811 \mathrm{McD}$ ougall directed Franchere to manage the Company's Oak Point sturgeon fishing camp and to trade with the Indians for sturgeon (Franchere 1967:100-101; Jones 1999:156). This effort started in February and continued through April. Engagement in this task exposed Franchere to the distribution of Indian sturgeon fishing camps, gear and the size of fish taken.

The trading circuit was about 30 to 40 miles long (CRM 50 to 90) covering both shorelines of the Columbia River from Oak Point to the shoreline of Sauvie Island downstream of the Columbia's confluence with the Willamette River. Franchere and his crew of 4 to 5 stopped at "...every fishing station, trad[ing] for as much fish as would load the boat, and send[ing] them down to the Fort" (Franchere 1967:100-101). Franchere never reported how many Indian fishing camps were present along the shoreline of the Columbia, but the Indian fishery was able to supply Fort Astoria with a substantial number of fish. How many of the Company's crew engaged in the winter sturgeon fishery was not noted, although from McDougall's account, at least 9 men took part in the fishery (Jones 1999:162).

The summer sturgeon fishery at Baker Bay lasted from August through September. One sturgeon reported by Franchere weighed $390 \mathrm{lb}$. [177 kg] with intestines and eggs removed (Franchere 1967:108). Based on weight this fish is a white sturgeon.

Franchere was less familiar and less active in the salmon fishery and trade. Much of the Pacific Fur Company's salmon trade was carried out at Fort Astoria directly with the Indians who brought their fish to the Fort. Franchere's description of these fisheries is limited to noting the timing of this trade and 
comments on the kinds of salmon.

\section{Fishing gear}

Franchere's description of fishing gear is important for its descriptive detail (Table 3-9). However, Franchere does not discuss where the gear he described was used.

Hook and line. Franchere's (1967:112) is the only account that explicitly states that the Indians caught sturgeon on a set line with multiple hooks (Figure 3-5). (Other accounts note the use of hooks for this fishery but do not describe the gear in detail.) The main line was attached to the shore with the outer end anchored by a "rock weighing fifteen or sixteen pounds" [6.8 - 7.2 kg]. The anchored end was marked by a float. Hooks on leaders were spaced twelve [3.7 m] feet apart and tied to the main line. The "...hooks...[were] ingeniously made of iron and bound by a strong cord of nettle so that they do not break. [The hooks were baited with]... a little fish, called mullet, passing the hook through the gills and sliding the fish along the cord that holds it to the line. [The rise and fall of the cord moves the]... bait giving the appearance of being alive; the sturgeon, deceived, swallows the bait and is caught".

The Pacific Fur Company's blacksmiths manufactured hooks for the Company's sturgeon fishery. These were traded and on a few occasions, tribal fishers took company gear from fishing locations. Franchere states that the Indians also manufactured hooks, "ingeniously made of iron" for their own use (Franchere 1967:112), but the style of the hook is not mentioned.

Hook and line gear was owned by individuals (Franchere 1967:61-62) and used by individuals operating out of small dispersed fishing camps. This suggests a fishery organized around family units or small groups of 
individuals.

Darts [Spears]. Franchere discusses the construction of a fishing spear or harpoon, a type Kroeber and Barrett (1960:74) refer to as a single toggle harpoon. Franchere reports: "[D]arts, or harpoons, are made of two pieces of curved bones, in the middle of which they bind a small iron point about half an inch long. The bone pieces are tied firmly together and are separated at the top to hold the shaft, which is a long pole with two forks" (Franchere 1967:112). When a fish is struck, the barbed head detaches from the shaft but remains attached by a long cord to the shaft, allowing the fish to be played and then drawn from the water when it is worn out.

Funnel net. A specialized net for sturgeon that Franchere called a funnel net was,

.... made of nettle fibers, in the shape of a funnel five or six feet wide [1.5 m-1.8 m] and ten to twelve feet [3-3.6 m] long. At the extremity that ends in a point the funnel opens and closes at will by means of a cord, on the other end of which is hung a stone that weighs seven or eight pounds. Another cord is tied to a piece of wood in such a manner that when the cord attached to the stone is pulled, the sack closes, and when slackened it opens.

When the net is thus readied, two men embark in a small canoe and, each taking an end of the cord, they drop it on the bottom and draw it along as they drift. The sturgeon searching for food sees the white object at the end of the net; he swims in and, pushing against the sides, he moves it, this movement warns the fisherman, who quickly close the net (Franchere 1967:112-113).

Seine nets. Franchere provides one brief comment on the large nets used to take salmon. "Their nets are made of nettle fibers and are from eighty to one hundred fathoms [146 -183 m] long" (Franchere 1967:112). He does not include any description of net weights, floats, mesh size or how the net was deployed. 
Eulachon rake. Franchere described and named the "smelt rake" used to take eulachon. "The small fish that we call smelt and that the Indians call outhelekane (candlefish) is caught with a rake. The rake is nothing more than a long pole, on the end of which some small pointed pegs are fixed. Passing this back and forth in the water, the fishermen hooks the fish on the pegs and soon has enough to fill a canoe" (Franchere 1967:113).

\section{Robert Stuart: 1811-1812}

Robert Stuart was a partner in the Pacific Fur Company. He arrived with McDougall, on the Tonquin, in the spring of 1811. From the beginning he traded for furs and was tasked with determining the potential for fur trade in a number of places: He explored the southern Washington coast line, tributaries of the Columbia River within the study area including about 200 miles of the Cowlitz River, and the Willamette River above the falls. He was sent to the upper Columbia River to evaluate that area, but conflict with Indians at The Dalles resulting in the loss of trade goods, shortened this trip and the party returned to Astoria after a brief excursion. Through these ventures he became familiar with the local tribes, various subsistence pursuits they engaged in and the landscape of the study area.

During June 1812, he was put in charge of an overland party that carried dispatches to Jacob Astor at the Company's headquarters on the east coast (Rhonda 1990:239-240). Based on the record he kept of his overland trek, Stuart is credited with exploring and mapping what would become the Oregon Trail.

Most of his journal is an account of the overland trip. However, the journal begins with a description of the lower Columbia River including 
comments about the Indians and a statement of the fisheries (Rollins 1995:337). His remarks provide a sense of the general environment where fish were taken, what gear was used with additional information reported for the eulachon and sturgeon fisheries and the July chinook fishery at the Cascades.

\section{Fish types noted}

Stuart's fish list includes a comment on lamprey which is one of the two records noting that fishery (Table 3-10). He also identified the chum fishery and its relative economic importance.

Chum. Dog-tooth salmon are taken from August through December (Rollins 1995:8). They have "a double row of teeth exceedingly sharp and at least half an inch long" (Rollins 1995:8). While Stuart does not report on the external color of his dog tooth salmon he provides three remarks pointing to chum: (1) the accentuated teeth of spawning adults; (2) the use of small creeks and; (3) the August-December timeframe when these fish are present. These remarks are all consistent with chum salmon.

According to Stuart, chum are an inferior fish compared to chinook salmon (Rollins 1995:8). However, chum are important because once smoked, they were the post staple until February when sturgeon and eulachon became available.

Chinook salmon. He considered the salmon taken from May to August as the finest of the salmon. Spring and summer chinook migrate through the study area during this period. Stuart does not make any specific reference to fall chinook salmon. His comment on the "best salmon" is important because it distinguishes this fish from chum salmon. 
Chub. Stuart mentioned chub as a fish taken by the Indians but provided no description of the fish, information on the gear used to take it, its resource value, or place of this fishery (Rollins 1995:7).

Lamprey. Stuart noted the presence of lamprey, but did not discuss the fish in any detail (Rollins 1995:7).

\section{Fishing locations}

Stuart reported the locations of fisheries and identified specific places by name (Table 3-11). He also noted where fishing for certain species occurred in more general terms.

Stuart states that Oak Point is the "best and almost only Fisheries of Uthulhuns and Sturgeon" (Rollins 1995:30). Although there are other fisheries for both eulachon and sturgeon, Oak Point is situated in close proximity to an important eulachon spawning area and as a consequence to a location where sturgeon are likely to have concentrated to prey on eulachon. The eulachon spawning area is located along the north shoreline of the Columbia River from the upstream end of Puget Island almost to Stella, Wa. (Figure 2-2; Smith and Saalfeld 1955).

Stuart states that spring and summer chinook salmon were taken in the shallow waters of the Columbia River by net. Though this is a general comment it is important as a potential reference to seining which is not well described in most of the literature I cite.

The Cascades was an important fishery for salmon. Stuart describes in detail the methods used to take salmon and the relationship of the gear to the setting. 
Stuart's list of gear complements Franchere's and adds some additional information (Table 3-12). Stuart's record is important for his comprehensive discussion of the gear used to take salmon at the Cascades.

Platforms and hoop nets. Stuart reports the use of hoop nets and platforms (Figure 3-6) to take chinook salmon at the Cascades during July.

they [Indians at the Cascades] erect stages or scaffolds to project some distance from the bank, by binding two long but slender trees together with strong withes, next tying a stout piece of wood across the two former from 4 to 6 feet below where they are bound together-thus arranged this preparation is set erect in the water, when the ends of two Slabs Several Inches thick and from 20 to 40 feet long are laid on the cros[s] piece of the two uprights, so as to reach 6 to 8 feet beyond them, with the other end resting on rocks along the water edge-at the farther extremity are a few thin boards from Slab to Slab on which the Fisherman stands on plying his Scoopnett, on the end of this erection which rests on the shore are placed huge stones not only to be a counterpoise to the weight and exertions of the actor but also to give it sufficient solidity to resist the action of the current - The places chosen are always a point where the water is strongest, and if possible a mass of rock near the project between which and the shore the Salmon are sure to pass, to avoid the greater body of the current-the scoop nett used here is made fast to a Hoop to which a very long handle is attached the fisherman pushed this to the depths of several feet perpendicularly in the water allowing it to descend with the flood until it encounters the Salmon who struggling to go upwards, Keep the nett always distended and is pulled up with such ease that Boys are often employed, who succeed equally with the most robust Men(Rollins 1995:52).

Stuart commented that an "experienced hand would by a[s]suidity catch at least 500 daily" (Rollins 1999 (1935):52).

Spears. Spears were used to take chum salmon and sturgeon (Rollins $1935: 8)$. Stuart does not describe the gear in any more detail nor where it was used.

Scoop nets. Eulachon are taken with scoop nets "in immense 
numbers from the middle of March till the middle of April" (Rollins 1995:30). Scoop nets were also used to take salmon from platforms.

The use of scoop nets to take eulachon and salmon is important information. These fish have very different body sizes and are taken in different places. This implies gear sized for different fish and conditions. Although Stuart's description of scoop nets does not provide this detail, it is likely that the mesh size of the nets used for eulachon was different than those for salmon.

Seine nets. Seine nets were used in shallow water to take spring and summer chinook salmon. In a Postscript to his book, Stuart wrote that long seines were used to take salmon (Rollins 1995:252). It is not clear whether Stuart was discussing beach seining or seining in shallow water from canoes.

\section{Northwest Fur Company 1813-1814}

\section{Alexander Henry}

Alexander Henry was one of the business partners of the Northwest Fur Company (Gough 1992: xxviii). He entered the study area in November 1813, following the purchase of Fort Astoria by the Northwest Fur Company (Gough 1992: Ivi). Fort Astoria was renamed Fort George shortly after it was acquired by the Northwest Fur Company (Franchere 1967:90-91). Henry directed the company's operations from the field and Fort George, making trips to inspect work and trade with the Indians for subsistence. Henry kept a journal of observations, dating each entry. His entries included brief but detailed comments on fishing gear or certain parts of it and the fish taken. His record covers the period from November 1813 through May 22, 1814 providing a 
description of the winter fisheries and the period covering the start of the chinook salmon fishery. He also provided a note on one species of marine fish. On May 22, 1814 he drowned at the mouth of the Columbia.

\section{Fish types noted}

Henry's fish list includes species taken from November through May (Table 3-13). Henry provides the only reference to what is probably surf perch and he also mentions trout, another species not well represented in the literature / cite.

Salmon. On November 16, 1814 the Chinook Headman Comcomly crossed the Columbia estuary to trade 100 fresh salmon. Henry says these fish weighed between "5-18 lb [2.27-8.2 kg] each" (Gough 1992:610).

The information that the salmon traded on November 16, 1814 ranged in weight from $5-18 \mathrm{lb}$ [2.27-8.2 $\mathrm{kg}]$ is too broad a range to define a single species of salmon. Fall chinook, chum and coho could be present in November. There must have been some fall chinook in the trade as the upper limit, $8.2 \mathrm{~kg}$, is an average weight for fall chinook and exceeds the average weight of chum and coho. Chum average less than $5.4 \mathrm{~kg}$ and coho averaging less than $4.5 \mathrm{~kg}$ are both within the range of weights given. This may have been a mixed trade of fall chinook, chum and coho as all of these fish fall within the range, but there is no way to define the catch.

Chinook salmon. Henry reports the Indians at Willamette Falls taking salmon on March 25, 1814 (Gough 1988-1992:704). He reported that the first salmon are always taken at the falls, but the fishery is over by April. Information about this fishery is second hand and involves no trade. While these fish are probably spring chinook, there is no description to prove this 
point.

Chum. In a December trade, Henry traded for salmon that were covered in ... large Red spots... and [were] very lean and very soft " (Gough 1988:621). In January he again traded for fresh salmon of "various colors...some still retaining roe," all of poor quality (Gough 1992:632). These fish are too late for fall chinook. Coho are more uniformly colored. Chum on the other hand are frequently described as "streaked with blotches of red and dark hues of blue and green" (Behnke 2002:52). Chum are also present as late as December (Fulton 1970:29). These fish are chum.

Sturgeon. Henry traded sturgeon from November through April 1814 (Coues 1897; Gough 1992). His trade included many large fish. He reports that he "measured one nine feet long, which weighed $250 \mathrm{lb}$. [113.4 kg]" (Coues 1897:832). This fish was a white sturgeon by weight and size.

His trade during the winter corresponds with the eulachon run. White sturgeon concentrate in large numbers to prey on the abundant eulachon creating a situation allowing large numbers of sturgeon to be taken. Henry records trades of 40 sturgeon on February 24, 1814; 48 on March 19, 1814; 20 on March 29, 1814; and 15 on April 2, 1814.

Henry reports that many sturgeon were taken by hook and line. These fish are probably white sturgeon because green sturgeon do not forage in the Columbia River.

Henry's record is only a partial account of the sturgeon trade. Sturgeon were butchered, salted and placed in casks at Oak Point for storage and transported to Fort George (Coues 1897:838). These fish were probably not included in the count of individual fish because Henry did not oversee this 
work. Thus, Northwest Fur Company's trade was probably larger than what Henry reported.

His trade was very productive. He could feed his whole crew on sturgeon while noting that his "60 men, ...consume 13 sturgeon per day, weighing from 25 to $250 \mathrm{lb}$. [11.3-113.4 kg] each" (Coues 1897:832).

Lewis and Clark remarked that one sturgeon they obtained was the good of its kind. Similarly, Henry remarked on the edibility of a sturgeon noting that he traded for a "...very large sturgeon of the escargal kind and excellent...." (1988:612). This remark suggests that there was a sturgeon that was not favored as a food. There is a preference for white sturgeon as opposed to green sturgeon. Henry's remark suggests he is familiar with a sturgeon of lesser quality, implying that some consumption of green sturgeon may have occurred.

Eulachon. On January 6, 1814 Henry reports the arrival of the first eulachon. These along with sturgeon were taken near the mouth of the Willamette River (Gough 1992:635).

Surf perch. On April 12, 1814 "Some Chinooks came over and brought us a few silver bream, which they taken near Cape Disappointment. They measure 14 inches in length and 6 inches broad [ $36 \times 15 \mathrm{~cm}$ ] and are very good eating when fried in fat..." (Gough 1992:719). Silver bream may be Henry's name for surf perch. Cape Disappointment is located on the north shore of the Columbia River at the mouth where marine and fresh water mix. Brackish water is appropriate habitat for surf perch (Eschmeyer et al. 1983:226). The dimensions of the fish suggest a surf perch and some of these fish are silvery. However, the information provided is insufficient to 
determine species.

Trout. Henry reports two trades for 8 trout on April 8, 1814 but provides no description of the fish other than its name (Gough 1992:714).

\section{Fishing locations}

Henry spent much of his time on the river, investigating places and trading for fish. From January through February, Henry went on trading excursions with Franchere for sturgeon reporting on the status of this fishery within the study area (Table 3-14).

Sturgeon. Henry reported that the winter sturgeon fishery extended from December through April. On an expedition in February, Henry noted sturgeon fishing camps along the Columbia shoreline, along the east side of Sauvie Island; at Oak Point the number of large sturgeon was "immense", many were tied to stakes driven into shallow water. He also noted large numbers of sturgeon on the beaches near Coffin Rock and Coffin Mountain (Coues 1897:832;835).

Eulachon. According to Henry, eulachon are taken from December through March. On December 12, 1813 the first eulachon were traded (Coues 1897:786-787). January 6, 1814 Henry reported "[eulachon] being taken in ...abundance about the entrance of the Willamette River" (Gough 1988:635). A February 1814 entry reports Sauvie Island villagers drying eulachon inside their houses (Coues 1897:820).

Salmon. In his entry of November 19,1813 , Henry reports fresh salmon and sturgeon remains around the Chinook Indian houses of Baker Bay (Coues 1897:750). Although the presence of salmon and sturgeon is not sufficient to define a predatory relationship, sturgeon do forage on dying and 
spawned out salmon. Though this evidence is not strong, it points to a possible reason for sturgeon being taken at this time.

\section{Fishing gear}

Henry observed the use of fishing gear (Table 3-15). He also reported on finding gear, such as a drag net and fishing line, stored in a Chinook Village house in preparation for use (Gough 1992:613). Although information on gear storage is not detailed enough to describe exactly where gear was stored (or whether pits were used, which would be useful for archaeological questions) this record at least documents storage in houses.

Hook and line. Henry noted the presence of sturgeon fishing line in the Chinook Villager's houses in November 1813 and as part of the fishing gear in a Chinookan canoe going upriver to the sturgeon fishery. In February 1814, he reported the Indians on the Columbia River side of Sauvie Island pulling in their sturgeon lines in the early morning. He did not discuss the rigging of this gear or whether it was a multiple hook set line or a single hook gear (Coues $1897: 755,820,838)$. The Sauvie Island sturgeon fishery was organized around small tented groups camped on the beach fishing with hook and line.

Nets. The Indians took salmon in seine nets. "November 19, 1813 Salmon are taken in seines about 50 feet long, made with twine of domestic manufacture; the materials used are nettles procured from the natives above" (Coues 1897:753). Henry does not describe where these short seine nets were used or how they were operated.

Drag net (funnel net). In November 1813 Henry visited a Chinook Village house at Baker Bay. He noted gear used to take sturgeon, reporting, "We saw here one of their drag-nets for sturgeon, nearly in the form of a bag, 
with a small bunch of feathers tied to the lower end. The "small bunch of feathers ... tied at the lower end" lured sturgeon into the net (Coues 1987:755). Franchere called the sturgeon net a funnel net, but noted that sturgeon were drawn into the net by a small white object (Franchere $1967: 112-113)$. The feathers, the small white object, may imitate eulachon. Neither Franchere nor Henry named a particular place where the funnel net was used.

Rake [eulachon]. The eulachon rake was: “... a pole about 10 feet long and two inches thick, on one side of which was fixed a range of small, sharp bones like teeth, about one inch long, one-fourth of an inch asunder, the range of teeth extending six feet up the blade" (Coues 1897:838). Henry's description is more developed than Franchere's. Henry provides dimensions of the gear and states that the bone pegs were used as the "teeth" on this gear.

\section{INDIVIDUAL EXPLORERS AND RESIDENTS}

\section{David Douglas, April 1825-January 1827; 1830-33}

Douglas was a naturalist, specializing in botany. His journals record his botanical expeditions into the Willamette Valley and the upper Columbia River basin. Douglas arrived at the Columbia River on the vessel William and Ann on April 8 1825. On June 20, 1825 he went up the Columbia River to The Dalles and reported on the salmon fishery. During July, 1825 he explored the area around the mouth of the Columbia River. During August 1825, he travel on the Willamette River. During September 1825 he returned to The Dalles. In November 1825 , he visited the mouth of the Columbia River and then went over land toward Puget Sound, returning to Fort Vancouver via the Cowlitz 
River (Davies 1980:52-54). He spent most of 1826 in the upper Columbia River, returning briefly to Fort Vancouver and then up the Willamette River to the Umpqua River (Davies 1980:92). He returned to Fort Vancouver on November 19, 1826. He made visits to the mouth of the Columbia River and Gray's Harbor in December 1826. He returned to Fort Vancouver and left the Fort on January 20, 1827 with the "Hudson's Bay Company Overland Express" following the Hudson Bay Company's supply route up the Columbia River to Hudson Bay, sailing from there to Portsmouth, Great Britain (Davies 1980:16$17 ; 111-150)$. Douglas covered, literally, thousands of miles using Fort Vancouver as a home base and a place to store his botanical collections (Wilks 1959; Davies 1980).

He returned to Fort Vancouver sometime after August 1833. His stay at Fort Vancouver was very short. Soon after arriving he went up the Columbia River and over to the Fraser River. He left the northwest coast from the Columbia River on January 2, 1834. During this period he spent most of his time outside the study area. His account from this time does not include any useful information on the fisheries because his journal was lost in a canoe accident on the Fraser River (Davies 1980:154).

Douglas's record of 1825-1827 provides useful information. During one trip up the Columbia River in October he visited the Chinook Village (Baker Bay) and the village at Oak Point reporting the fish that had been taken and served to him. He did not comment on fishing gear used in the lower river although he did note the gear used in the vicinity of The Dalles, including seining nets. Some of his remarks on seining are appropriate for the use of this gear in the study area. 


\section{Fish types noted}

Douglas provides important comments on the fish of the study area adding information only alluded to in other accounts (Table 3-16).

Sturgeon. Douglas reports sturgeon were taken in April, July and December, and even though it includes just three months this record could be linked to the winter sturgeon fishery, the summer fishery in July at the Chinook Village and individual fish taken outside the main fisheries.

He notes the presence of white sturgeon in the canoe of "Cockqua, "principal chief of the Chenooks and Chochalii"....[which was] 10 feet long, 3 at the thickest part in circumference, weighing probably 400 to $500 \mathrm{lb}$..." (Wilks 1959:137-138). Noted on July 19, 1825, this fish was probably part of the summer sturgeon fishery. In December 1825, he reports a catch of 10 sturgeon in the Oak Point Village (Wilks 1959:240). The April comment merely notes the presence of sturgeon, along with "dry salmon" (Wilks 1959:102103).

Salmon trout. Douglas traded for a 15 pound $(6.8 \mathrm{~kg})$ salmon trout at the Cascades on March 21 1825. He describe this fish as "fine" (Wilks 1959:243). I suggest that this fish is a steelhead. First the similarity of this fish to trout is suggested by the reference to trout, although it is of larger size indicated by the use of the word salmon. It is too early for spring chinook to be taken at the Cascades and they would be recognized as chinook and not confused with salmon trout. As a minor point, Lewis and Clark also traded for salmon trout at the Cascades in April noting that no salmon were present (Moulton 1991:102).

Eulachon. Even though Douglas was present in April and December, 
he does not mention eulachon. Absence of eulachon is curious; even though December is early for the eulachon run, by April smoke cured eulachon should have been available. The 10 sturgeon he saw at Oak Point could have been drawn to the vicinity by eulachon. It is possible that eulachon failed to appear in 1825 , but this is speculative.

\section{Preserved fish}

One of the important comments in Douglas' account are his remarks on smoke cured salmon. His remarks addressed the quality of smoke cured chum. He clearly identifies smoke cured chum from smoke cured chinook. Douglas' account of a visit to a Chinook house clearly reports the difference (Table 3-16). In December 1825, Douglas went to "....Cape Shoal-water [Willapa Bay] to the house of my old Indian friend, Cockqua, who greeted me with that hospitality for which he is justly noted.... He regretted that dry salmon and berries of Gaultheria Shallon [salal] was all the variety he could offer me...it was too rough to venture fishing....The salmon is very bad, lean in the extreme, killed in small creeks in September, October, and November, in the spawning season: when dried it resembles rotten dry pine-bark" (Wilks 1959:239-240).

Douglas' remarks on the fish used to make the "dry salmon" are consistent with the timing of the presence and descriptions of chum salmon. The fish is abundant from September through November. It spawns in shallow streams in the study area. Its flesh is reported as lean with a distinctive texture that is different from other salmon.

In contrast, Douglas acquired another kind of dried salmon in a trade at Oak Point Village in late October 1825 and made no objection to this fish 
(Wilks 1959:146). Granted the contrast is modest, however Douglas was inclined to state his opinion especially on the quality of his food. For example, he notes a "fine salmon trout he purchased on March 21, 1825 (Wilks 1959:243) and the good sturgeon he had on April 19, 1825 (Wilks 1959:245). Considering that he commented on the quality of his meals, it is notable that he offered no disparaging comment on the dried salmon from Oak Point. Douglas does not provide any information of the source of this fish; determining where it was produced is not possible with the information provided.

\section{Fishing gear}

Even though it seems obvious that adverse weather may impede fishing, the comment from Cockqua that, "... the weather was too rough to venture fishing", is one of the few comments that note this limitation. It is probable that gear which requires direct observation of fish, such as spears and perhaps hoop nets, may not be appropriate gear when streams are flooding and discolored by run-off. It is also difficult to set seine nets during flood conditions. Weather is an important factor facilitating or restricting fishing, a matter not noted in other accounts.

Seine net. There is so little information on the use of seine nets, that any remark that is pertinent needs to be examined. Douglas did not record any information on fishing gear for the study area, however, he provided an important note on the limitation of seining gear. "[D]raught nets" (seine nets) were used to take salmon over the pocket beaches that develop between large basalt formations (Wilks 1959:129). The seine nets were limited to these areas because the net could be drawn over sand or water worn cobbles 
but would snag on exposed basalt bedrock. I consider this remark in more detail in a later chapter when I summarize the information on the use of seine nets in the study area.

\section{John Townsend, 1833-35}

Initially Townsend was a botanist with the Wyeth trading expedition (1834). The Wyeth party's overland expedition arrived at Fort Vancouver on September 16, 1834. On December 16, 1834 members of the party including Townsend, sailed for the Hawaiian Islands. Townsend returned to the lower Columbia River on April 15, 1835. On October 1, 1835, he served as the physician for the Hudson Bay Company for about a year. He left for the east coast on November 31, 1836 (Jackson 1978).

Townsend spent sufficient time within the study area that he should have been exposed to all of the fisheries. He provides important information on the fish he mentions, but he does not provide any information on the eulachon or the sturgeon fisheries. It's possible that he just did not write accounts of those fisheries because as he notes, the Indians were devastated by the "fatal fever" during the 1830's, and their subsistence efforts during his stay did not require the same effort.

\section{Fish types noted}

Townsend's record of fish is composed of fish taken from spring through the early fall (Table 3-17). He did not report on fish taken in the winter. He was out of the study area during the winter of 1834, returning in April 1835 and leaving again in November 1836. He spent one winter in the study area, but did not report a winter fisheries for sturgeon or eulachon.

Chinook salmon. On October 18, 1835 Townsend was traveling with 
the Chinook Indians up a tributary of Baker Bay to a short portage and then on to a stream draining into Willapa Bay. Upon leaving Baker Bay through a slough the party went up a stream, which he reported filled with "... salmon weighing...fifteen to twenty-five pounds [6.8 -11.3 kg]" (Thwaites 1966:367368). By size and timing these fish are fall chinook salmon.

Lamprey. Townsend reports a lamprey fishery at the Cascades in July.

\section{Fishing locations}

Townsend reported on fisheries that occurred from spring through the fall (Table 3-18). He also commented on the availability of fresh and preserved fish.

On April 21, 1834 he returned to the Columbia River after wintering in Hawaii. The sailing vessel stopped at Oak Point. The Oak Point Chief and his wife welcomed the vessel with a gift of "red deer and sturgeon" (Thwaites 1966:318), but Townsend did not witness anyone fishing for sturgeon.

Lamprey enter the Columbia River as early as April, and migrate over Willamette Falls to spawning grounds. Townsend reported smoke cured lamprey and sturgeon in a house on the Clackamas River near its confluence with the Willamette River on April 24, 1834.

On an excursion up the Columbia River, on July 3,1835 he noted thousands of fresh lamprey smoke curing in the houses downstream of the Cascades on Hamilton Island (Thwaites 1966: 346-347). There must have been an important lamprey fishery at the Cascades, but Townsend does not report anyone fishing.

At the same time he noted lamprey, Townsend reported the salmon fishery. These fish were probably spring or summer chinook, but Townsend 
did not describe the fish (Thwaites 1966: 346-347).

In October 1835, Townsend noted the fall chinook fishery in Baker Bay. His discussion includes a description of the fish (Thwaites 1966:367-368).

\section{Preserved fish}

Townsend reported thousands of lamprey smoke curing in the lodges along the north shoreline of the Columbia River (Thwaites 1966: 346-347).

Townsend remarked during an October visit to a Chinook settlement near Willapa Bay, "The house in which we sleep tonight is not near so comfortable as the one we have left. It stinks intolerably of salmon, which are hanging by scores to the roof, to dry in the smoke... (Thwaites 1978:256).

He reported the presence of smoke cured sturgeon and lamprey in a house at the confluence of the Clackamas and Willamette Rivers (Townsend 1905:320).

\section{Fishing gear}

The range of fishing gear Townsend reports is limited, but he provides more detail on gaffing than any other account (Table 3-19). He also recorded the use of expedient gear, a canoe paddle, to take fall chinook.

Gaffs. On October 17, 1835 the Baker Bay fishery for chinook salmon was in full operation. Townsend remarked:

In our passage through some narrow channels today we saw vast shoals of salmon which were leaping and curvetting about in every directions, and not infrequently dashing their noses against our canoe, in their head long course. We met a number of Indians engaged in fishing, Their mode of taking salmon consists of a pole about twelve feet long, with a large hook attached to the end. This machine they keep constantly trailing in the water and when a fish approaches the surface, by a quick and dexterous jerk, they fasten the iron into his side, and shake him off into the canoe. They say they take so many fish that it is necessary for them to land about three times a day to deposit them 


\section{(Townsend 1905:365).}

Canoe Paddle. Further along on this trip, before the party passed over to Willapa Bay, he noted the use of a canoe paddle to take chinook. Large numbers of chinook salmon were in a stream about 9 feet wide. Salmon were clubbed with a paddle, probably an example of improvised gear, rather than a regular method.

Spears. Townsend noted that salmon spears were part of the grave goods on Mt. Coffin (Thwaites 1966:309). He provided no information on the use of salmon spears.

He does not discuss the gear used to take lamprey.

\section{Charles Wilkes, May 1841-October 1841}

Charles Wilkes commanded the U. S. Exploring Expedition of 18381842 composed of six sailing vessels. The expedition, charged with collecting scientific information, produced navigation charts, descriptions of natural history for some places visited, and collected specimens of birds, mammals, fish and plants. Ethnographic observations and linguistic information were also recorded. The expedition circumnavigated the earth arriving on the northwest coast of North American in the spring of 1841.

The expedition arrived at the entrance to the Columbia River on May 12, 1841 , but because they could not cross the bar they sailed along the Washington coast and into Puget Sound. Members of the expedition arrived at Fort Vancouver from a point on the southern extent of Puget Sound, crossing over to the Cowlitz River and then downstream to its confluence with the Columbia River. The expedition left the Oregon territory on October 31, 1841 (Buerge 1987). 
Wilkes dispatched exploration parties overland and along the coasts of what would become Washington, Oregon and northern California (Viola and Margolis 1985). From the spring of 1841 through October 31,1841 , Wilkes and some of the members of his staff explored and charted Puget Sound and the lower Columbia River.

Wilkes personally directed the expedition's investigations of the lower Columbia River. Members of the party visited the spring chinook fishery at Willamette Falls and the Cascades. One of the Expedition's major contributions is a detailed discussion of the Willamette Falls spring chinook fishery. No other account provides more than a note of this fishery.

\section{Fish types noted}

Wilkes' account of the fish were those taken from May through October (Table 3-20). He was not present to observe the winter sturgeon fishery. Wilkes' record of fish deals mostly with the spring chinook salmon with a brief note on fall chinook in the Cowlitz River (Table 3-20). He also provided a short comment on the presence of suckers and lamprey at Willamette Falls although there was not a fishery for those fish during his visit.

Chinook. Wilkes reports that: "There are four different kinds of salmon, which frequent this river [Columbia] in different months...."(1852 (4):366). He remarked that, "the latest appears in October, and is the only kind that frequents the Cowlitz River. The finest sort is a dark silvery fish, of large size, three or four feet long, and weighing forty or fifty pounds [18-23 kg]" (Wilkes $18524: 366)$. The 40 or 50 pound salmon Wilkes discusses is a fall chinook. At one time, the Cowlitz River was one of the most productive spawning grounds of fall chinook (Fulton 1968: Table 5). Wilkes does not provide 
information on the size or physical appearance of any other salmonids.

Wilkes notes that the quality of salmon decreases as they migrate upstream.

In his opinion the salmon taken in the upper Columbia are hardly worth eating,

.... [but] those caught at the mouth of the Columbia, are totally different in flavour.... [they are] the richest and most delicious fish I ever recollect to have tasted: if anything, they were too fat to eat, and one can perceive a difference even in those taken at Willamette falls, which, however, are the best kind for salting" (Wilkes 1852 4:366).

What he has noted is a decrease in the fat content of salmon as they migrate upstream.

Lamprey. Wilkes reports lamprey at Willamette Falls during the June spring salmon fishery, although no one was fishing for lamprey. "On the rocks are to be seen large knots of lamprey eels, worming themselves up, which make them look at a little distance as if alive with snakes" (Wilkes 1845 $4: 346)$.

Sucker. No other account I cite mentions the presence of sucker by its common name except for Wilkes. Wilkes' party noted the presence of suckers during the June spring chinook salmon fishery at Willamette Falls. Following a request from an expedition member, an Indian fisher netted a "...beautiful specimen of a small-sized sucker..."(Wilkes $18454: 366)$. The fish was given to Drayton, one of the illustrators of the expedition, who drew the fish. (The illustrations of fish from the expedition have never been completely published, and those that are published do not include fish from the Pacific Northwest). The accounts do not mention a fishery for suckers.

Sturgeon. Wilkes does not mention sturgeon fishing nor any fresh 
sturgeon at the villages he visited. The expedition was in the study area from May through October, and yet do not mention anyone fishing for sturgeon.

\section{Fishing locations}

Navigation charts of the Columbia River produced by the expedition record fishing locations but not the gear used (Table 3-21). In May 1841, members of the expedition went upstream from the Columbia River estuary passing Kathlamet Island [Tenasillahe Island] where on a survey map they recorded a "Fishery" on the northeastern shoreline of the island on a survey map (Vaughan et al 1980: copy of Wilkes map: Columbia River Sheet 3, 1841). No mention of gear or actual setting (such as fishing from the beach or a canoe) was included in the comment. Passing Puget Island, Wilkes reports an Indian fishing party taking large salmon, but he does not mention the gear used (Wilkes 1845 4:324). The party stopped at the Oak Point Village and traded for fresh salmon (Wilkes 1845 4:324). These observations indicate an active mainstem fishery for spring chinook in May.

Wilkes provides detailed discussions of the chinook salmon fishery at Willamette Falls and the Cascades. He also notes the presence of large salmon on taken from the Cowlitz River but does not discuss a fishery.

\section{Fishing gear}

Wilkes' (1845 4:324) description of gear is limited to Willamette Falls and the Cascades (Table 3-22). Wilkes reports the physical dimensions of Willamette Falls and the construction and placement of fishing platforms at the falls and the two different kinds of gear used. Willamette Falls is 350 yards [320 m] wide with its greatest fall about 25 feet [ $8 \mathrm{~m}]$. The Indians fished the upstream edge of the falls from canoes tied to poles driven into cracks in the 
basalt rock formation. Salmon were taken in the pool at the foot of the falls from platforms with hoop nets.

Wilkes also reported on the salmon fishery at the Cascades on the Columbia River. A different form of fishing platform was used at the Cascades, than was used at Willamette Falls. Hoop nets were also used at the Cascades to take salmon.

Gaff. At Willamette Falls, spring chinook were taken near the upstream edge of the falls from canoes. Wilkes reports, "Some of the Indians are in the habit of coming down in canoes to the brink of [Willamette] falls, where they secure themselves by thrusting down poles in the crevices of the rock. There they take many fish, that have succeeded in passing the lower fall with a hook fastened to the end of the pole" (Wilkes 1845 4:345).

Hoop Net. The Indians used a 4 foot [1.2 m] diameter hoop net mounted on the end of a 30 foot $[9 \mathrm{~m}]$ pole. The net was strung around a hoop and was closed by sliding the net along the hoop trapping fish as they entered the bag. The salmon were captured as they swam upstream and the net was swept downstream by the current. Wilkes reports as many as twenty large fish could be caught by one person in an hour (Wilkes 1845 4:345). Hoop nets were also used at the Cascades to take spring chinook, but Wilkes does not describe these nets beyond naming them.

Platforms. At Willamette Falls, pairs of wood poles were placed horizontally over the water anchored by wedging them into the basalt rubble along the rock face of the falls and adjacent shorelines. A platform for standing was constructed over the poles. From the end of the platform the hoop net was drawn downstream taking salmon as they swim upstream 
(Wilkes 1845 4:345).

Platforms were also used at the Cascades but were fished from the midsections of the walk way. Wilkes reports that boulders and other rocks under the platforms were aligned forming " 50 foot long channels" parallel to the shoreline (Wilkes 1845 4:380). Chinook salmon swam up the channels to avoid the swifter currents and were netted as they passed under the platforms.

Weir. Wilkes' party produced a drawing of a wooden stake fishing weir spanning a section of the Chehalis River (Hajda 1990:506). Similar gear is not reported for the study area.

\section{James G. Swan, 1852-1855}

Swan was a resident of Shoal-water Bay [Willapa Bay] from 1852 to 1855. He had a small cottage on the Bay where he wintered (1973 (1857):140). He wrote about the Chinook who resided at the Chinook Village, at Baker Bay on the Columbia River and at Willapa Bay. At this time Swan (1973 (1857):110) stated that the Chinooks numbered slightly more than 100.

Swan followed the Chinooks as they moved from Willapa Bay to Baker Bay providing a record of their fisheries. The information I cite is mostly Swan's record of the Chinook Indian fisheries at Baker Bay, but I include the fish the Chinooks took in Willapa Bay if they are also found in the Columbia River because they suggest additional resources.

Swan's record provides the detail of particular places that is missing in other accounts. Franchere's narrative, for example, discussed in a general manner what he saw from the Columbia River mouth to Sauvie Island, but he rarely stated where particular gear was used to take certain fish. Swan on the 
other hand, discusses the Indians fishing in Baker Bay and adjacent Willapa Bay. He notes salmon fishing along the beach in front of the Chinook Village and names places like the Nasal River or the tidal shallows of Baker Bay.

The detail in Swan's account may come from his awareness of the practice of ethnography and his desire to produce a work that met his understanding of the requirements of an ethnography. His record is specific to the Indians he knew, as he states, "I only give an account of those I have lived with, the Chenooks, Chehalis, and one or two tribes north of Gray's Harbor" (1973 (1857):6). Thus, his record may be more comprehensive than other accounts because he deliberately attempted to describe the lifeways of particular people and individuals. He notes that his record is incomplete, he had lost some of his notes and was unable to give an account of the legends and vocabularies of these people (Swan: 1973 (1857:6).

\section{Fish types noted}

Swan reported six different types of fish taken in Baker Bay and Willapa Bay (Table 3-23) from his observation of the Chinooks fishing in these places. While he frequently distinguishes the two places, in a few instances it is not clear if he is referring to Willapa Bay or Baker Bay. Swan's record adds two types of fish, flatfish and herring, as potential fish resources not reported in other accounts. These fish were taken in Willapa Bay (Swan: 1973 $(1857: 27,83)$.

Turbot and flounder. The Chinook took what Swan calls turbot and flounder from the sand flats of Willapa Bay in the late summer. No gear was used. During low tide the flat fish were pinned by stepping on them and picked up and tossed onto the beach. Swan does not provide a description of 
these fish. The name turbot is used today as the common name for a number of species of the genus Pleuronichthys (Eschmeyer et al. 1983:292-294). Willapa Bay is not turbot habitat, turbot are marine fish (Eschmeyer et al. 1983: 292-293; Monaco et al. 1990: Table 3). Starry flounder are common in Willapa Bay (Monaco et al. 1990: Table 3), but without a description of the fish the species Swan reported is unknown.

Herring. Swan mentioned the taking of herring in Willapa Bay, but he did not report a similar fishery in the Columbia River. Historically, the Columbia River estuary was a herring spawning area (Lassuy and Moran 1989: Figure 2). As previously noted, herring spawn along both shorelines of the Columbia River from the mouth to a point about $55 \mathrm{~km}$ upstream.

Sturgeon. The sturgeon "weigh from three [136 kg] to four hundred [181 $\mathrm{kg}$ ] pounds, and are from twelve [3.7 $\mathrm{m}$ ] to fifteen feet [4.5 m] long" (Swan 1973 (1857): 245). These fish are white, not green sturgeon because they exceed the maximum size of green sturgeon typically set at 6.5 feet $(2 \mathrm{~m})$. These fish were taken in Baker Bay, although Swan stated they were also present in Willapa Bay.

Chinook salmon. Swan's record suggests he identified two runs of chinook. The first run of "...Chenook salmon commences to enter the [Columbia] river the last of May and is most plentiful about the 20th of June (Swan 1973(1857):103). The May date is the initiation of the chinook salmon fishery given Swan's account of the first salmon taken. Fishery studies report the presence of adult chinook as early as February (Fulton 1970:3) but the fishery was apparently started when fish were more generally abundant or concentrating as they followed the shoreline on their upstream migration. The 
increase in numbers of salmon through June correspond with other accounts and links this increase with the spring fishery at Willamette Falls. Swan notes that these fish "do not at once proceed to the headwaters, but linger around the mouth for several weeks before they are prepared to go farther up" (Swan 1973 (1857):103). These fish however, do not migrate into the tributaries of the study area, even though some hold in the deep pools at mouths of creeks. Some of these fish range in size from 65 to $85 \mathrm{lb}$ [30-39 kg] (Swan 1973 (1857):103). The size and use of the Columbia River as a migration route and absence in local tributaries are all consistent with spring run chinook salmon. However, based on the arrival of fish at the estuary and June 20th date when the catch becomes plentiful, is later than expected.

Swan does not specifically reference a summer run, rather the May fishery continues through June (Swan 1973 (1857)). As far as the mainstem fishery for chinook salmon, there would be no break between spring and summer runs, the fish would continue to migrate upstream out of the study area.

Fall chinook salmon were the second run of salmon and were taken in Baker Bay and in tributaries of Willapa Bay. Swan reports that during the summer sturgeon fishery in Baker Bay other fishers were taking salmon (Swan 1973 (1857):103).

One of Swan's most detailed description is of the fall salmon fishery on the Nasal River, a tributary of Willapa Bay. The Chinooks of Swan's account fished the Nasal River starting in late August (Swan 1973 (1857:135) taking newly arrived fish in the deep channels of the river (Swan 1973 (1857:138). These fish are described having the same form, but differing in color (Swan 
1973 (1857):140) from the "Chenook salmon" taken from Baker Bay in the spring (see Swan 1973 (1857):103). The fall chinook salmon have "dark, speckled sides and a dull whitish belly" and are not as fat as the spring fish (Swan 1973 (1857:140). Given the same form, but differing in color suggests fall chinook salmon. Fall chinook are more mature than the fish of the spring run, exhibiting the external appearance associated with spawning chinook. Swan would not see spring chinook in with their spawning colors because these fish are comparatively immature and are beginning their spawning migration up the Columbia. Spring chinook would not develop spawning colors for months, while fall chinook are in spawning colors as they or shortly after they enter the study area.

These are not chum. Chum do not have speckled sides and are distinctively colored as previously noted (Behnke 2002:51-52). In addition, Swan (1973 (1857:140) clearly distinguishes these two fish in a detailed discussion of chum salmon following his discussion of the fall salmon fishery on the Nasal River.

The fall salmon Swan describes are not coho. Coho are not dark but red as they approach spawning. When coho are fresh from the ocean they are silver. The timing of the fishery starting in late August, the dark color of the fish and reduced fat content are consistent with fall chinook salmon.

Chum salmon. Swan discussed a fish he called the dog tooth (also called hawk-nose or hook-billed) salmon. This fish runs from August December in Willapa Bay and "every river, brook, creek, or little stream is completely crammed with them" (Swan 1973 (1857):140). They have, "dark speckled sides and a dull whitish belly..." [and are not as fat as the] 'Chenook 
salmon'. After they spawn "their flesh loses its pink color, and is as white as a codfish. At this period they are not considered of any value either by whites or Indians, who term them musachee, or bad" (Swan 1973 (1857):140).

Most of the characteristics Swan used to describe this fish link it to chum salmon. Chum are present from August through December. The use of every small body of water for spawning is a characteristic of chum. Chum can successfully spawn in shallow slow moving water. Chinook salmon require deep water with a fast current. Dark speckled sides, however, are not a typical way of describing the chum's spawning color, although Swan may mean that their spawning color is not uniform. The pink color of the flesh turning white after spawning is a characteristic of chum. Exaggerated teeth, timing of the spawning run, the habitat used for spawning suggest chum, but the body color is not consistent.

Swan does not discuss a fishery for dog-tooth salmon within the tributaries of the Columbia River estuary. This is also curious, given previous observers reported chum spawning activity (see Stuart (Rollins 1995:8).

Coho. Swan does not discuss any salmonid that may be coho salmon.

Trout. Swan (1973 (1857)) was a sportsman and he used fly fishing gear to fish for trout on the Nasal River during the Indian's fall chinook fishery. His description of different flies (lures) indicates he was familiar with trout fishing and purposely sought to take these fish. While he fly fished without success Swan watched a couple of Indians fishing and catching trout from a canoe with hooks baited with salmon eggs. He did not provide any description of the fish, consequently which species he was trying to catch and the Indians were catching is uncertain. The trout were foraging for salmon eggs, and were 
in a deep pool downstream from a fall chinook salmon spawning area.

\section{Preserved fish}

The Chinooks preserved two fish, fall chinook and sturgeon. Swan discusses the procedure for butchering and drying fall chinook. He states,

The salmon is split down the back, so as to separate the head, backbone, ribs and tail from the rest of the body. The backbone, which has a large portion of the fish adhering to it, is generally eaten first, and is cooked either by boiling or roasting; the heads and tails are strung together and dried. The rest of the fish is sliced in thin wafers, and is also dried without salt. When perfectly cured, it is packed in baskets for winter's use or for trading and stored in a dry place (Swan 1973 (1857):110-111).

On a trip up the Nasal River in August to a fall chinook salmon fishing camp Swan observed the Indians drying salmon. He reports: "On arriving at camp, we found the Indians who were already there had plenty of salmon, which they were drying for winter's use (Swan 1973 (1857):136-137). He did not report the process, but I assume the fish were prepared in the manner discussed above.

Swan reports that some of the dried fish was traded to Indians in the interior. These fish were "... frequently pounded up fine, and firmly pressed into baskets of ten or twelve pounds each" (Swan 1973 (1857):111).

Swan's comment on the production of cured fish traded to the interior is the only record discussing the production of pounded fish in the study area. Pounded fish is usually thought to be a process exclusive to The Dalles area. Given Swan's comment it is interesting that there is only one report over the period of my study concerning a trade for pounded salmon. McDougall noted it's presence at the Oak Point Village in November (Jones 1999:56).

Swan also reports that salmon was smoke cured in lodges. He 
provides a detailed discussion of house construction including the statement that, "Overhead poles are laid, on which salmon, berries, or anything else they wish to preserve is placed to be dried by the smoke" (Swan 1973 (1857):111).

Sturgeon was also processed for preservation. Swan discusses the procedure of butchering and smoke curing the fish. He states:

The fish,[sturgeon] after being carried home, is opened, care being taken to save all the blood, which is put into a kettle with some choice cuts, and then boiled. The head, like that of the salmon, is esteemed the best part, and is either boiled, or cut in strips and broiled or roasted before the fire. The pith of the back bone is considered a great luxury, and is eaten raw; and although not having more flavor than the white of an egg, is not unpalatable.

The rest of the fish is cut in thin strips and dried in the smoke (Swan 1973 (1857):246).

Smoke curing sturgeon in this manner produces thin strips not the product that McDougall traded for, which was sold by the piece with 10 to 12 pieces packaged in bales (Jones 1999:82). McDougall's bales of sturgeon appear to be much more substantial than the smoke dried strips Swan reported.

\section{Fishing locations}

Swan provides place names for many of the fisheries (Table 3-24) instead of a more general location.

Chinook salmon. The Chinook Villager's seine net fishery for chinook salmon occurred along the shoreline of Chenook Beach, at the upstream end of Baker Bay near the outlet of the Chinook River by the Chinook Village (Swan 1973 (1857):104). This fishery was for spring and summer chinook migrating through the estuary. The fish appear as early as May but the major catch was in June (Swan 1973 (1857):104). 
The fall chinook salmon fishery was focused on the confluences of creeks and tributary streams of Baker Bay. The fall chinook fishery targeted fish spawning in lower Columbia River tributaries. Swan describes two places where fall chinook were taken on the Nasal River: (1) in tidal waters and (2) on the free flowing reaches of the stream above tidal water. A Chinook Villager fishing camp was located about 10 miles up the Nasal River near a falls. When he arrived at the Chinook's camp they were drying chinook salmon for winter (Swan 1973 (1857):136-137).

Chum salmon. The chum salmon fishery focused on the tributaries of Willapa Bay. Swan does not report a chum fishery in Baker Bay. This may be because Swan wintered on Willapa Bay. Swan's information on the chum fishery is important because it concentrated on small streams, a place where fish were abundant and could be easily taken from a restricted space.

White sturgeon. White sturgeon were taken by gaff at Baker Bay in July. Swan reports that sturgeon taken in Willapa Bay are like those at Baker Bay and "are delicate flavored and tender, finer grained than any sturgeon I have ever seen in any part of the world" (1973 (1857):246).

One Chinook Village head man, at the mouth of the Chinook River, had sturgeon heads mounted on poles signaling his success at this fishery. Displaying fish heads may indicate the successful expertise of this specialist, although Swan (1973 (1857):246) wondered why he bothered.

\section{Fishing gear}

Swan's account is the only detailed account of seine net fishing gear and the method of use of this gear for the study area. No other record provides the level of detail Swan reported, and no other account discusses net weights 
and floats. As such his record is cited as evidence of a large net fishery on the lower Columbia River (see Warner and Warner 1975; Pettigrew 1977; Dunnell and Campbell 1977).

Swan's account is also unique regarding the use of scents to entice fish. His descriptions of particular types of salmon and sturgeon gear (Table 3-25) are more detailed than any of the previous records. Swan's (1973(1857):39) description of this gear also includes an illustration, a record most other accounts do not include. His record includes measurements, discussion of materials, comments on the manufacture of some of the gear and how it was assembled.

Scents. Swan is the only source reporting the use of plant as part of the fishing gear tool kit. Hooks and nets were rubbed with wild celery (possibly Oenanthe sarmentosa see Gunther 1973:42) in order to entice fish to bite and attract salmon in particular to the nets (Swan 1972:140).

Hook and Line. Hook and line were used to take trout, an unknown salmonid, on the upper reaches of the Nasal River. The hook was baited with salmon roe attached to 3 fathoms [5.5 m] of line (Swan 1972:139). No other fish is reported to have been taken by hook and line.

Gaff. The Chinook Villagers forged their own hooks for gaffing salmon and sturgeon (Swan 1973(1857):38). The hooks were manufactured from files and rasps traded from local settlers. The hooks were about the size of a "shark-hook" and had a wooden socket [a foreshaft] made by hollowing out the stem of the wild raspberry bush (Rubus spectablis)..." for attachment to a pole (Swan 1973(1857):38). The foreshaft is tied by a length of cord 3 feet [90 $\mathrm{cm}$ ] long; the other end is held in the hand. Salmon were gaffed by trailing the 
hook and pole behind a canoe snagging salmon when they were near the water surface. The salmon were drawn into the canoe by the line.

Salmon were also taken in the deeper water at the confluences of tributary streams (Swan 1973 (1857):38-41). The gaff was drawn through the deep pools snagging fall chinook as they lay in deep water.

Sturgeon were gaffed with gear similar to salmon gaffs but heavier. This gaff used a "cod sized fishing line" with a hook mounted to the end of a pole. The gear was held perpendicular to the water surface, the hook was walked along the bottom where it was driven into a sturgeon. Line was played out as the sturgeon struggled to get free; when the fish was tired it was drawn to the side of the canoe and rolled into it (Swan 1973 (1857):245).

Spears. Spears were used by the Chinook Villagers to take fall chinook in the shallow waters of tributary steams in Baker Bay. Swan (1973 (1857):39) includes an illustration of a two pronged spear, although in his text he describes a single pronged spear. (see H. Stewart (1977:70), discussing historic fisheries in British Columbia, illustrates similar gear calling it a sturgeon harpoon.) The blade of the spear was fashioned from a file or rasp steel, with segments of elk antler used to manufacture the barbs or valves. Valves are paired on opposite sides of the spear forming a socket for the shaft. The shaft was inserted between the valves, a line is attached from the spear head to the shaft, so that when a fish is struck, the shaft separates from the spear head and the fish is retrieved by the line. Swan reports that in a four hour period the Indians took over one hundred salmon by spearing (1973 (1857) :38-41).

Nets. Swan's (1973 (1857):104) description of the Chinook Villager's 
salmon seine provides information on materials used to construct the net; its dimensions; how the net was fished and the number of people it took to operate it. Swan calls attention to the seine net comparing it with the nets used by the "whites". His comparison suggests shared style rather than implying that the Chinook net was derived from a white model.

According to Swan $(1973(1857): 104)$ the webbing of the nets was made from a "twine spun by [the Indians] from the fibres of spruce root prepared for the purpose, or from a species of grass brought from the north by the Indians". The floats are made from pieces of cedar. The net's footline was held down by "round beach pebbles, about a pound each, notched to keep them from slipping from their fastenings" (Swan 1973 (1857):104). The weights are tied to the net by "withes of cedar firmly twisted and woven into the foot-rope of the net". The nets vary in size from a hundred feet long to a hundred fathoms or six hundred feet and from seven to sixteen feet deep (Swan 1973 (1857):104).

The nets are set at the top of high tide before the tide ebbed and then as Swan reports:

A short distance from the shore the current is very swift, and with its aide these nets are hauled. Two persons get into the canoe on the stern of which is coiled the net on a frame made for the purpose, resting on the canoe's gunwale. She is then paddled up the stream, close to the beach, where the current is not so strong. A tow-line, with a wooden float attached to it, is then thrown to the third person, who remains on the beach, and immediately the two in the canoe paddle her into the rapid stream as quickly as they can, throwing out the net all the time. When this is all out, they paddle ashore, having the end of the other tow-line made fast to the canoe. Before all this is accomplished, the net is carried down the stream by the force of the ebb, about the eight of a mile, the man on the shore walking along slowly, holding the line till the others are ready, when all haul together. As it gradually closes on the fish, great caution must be used to prevent them from 
jumping over; and as every salmon has to be knocked on the head with a club for the purpose...(Swan 1973 (1857:104-107).

Weirs. Herring were trapped in Willapa Bay in weirs. Swan reports "...that shoals of herring visit the Bay, and are readily caught by the Indians, either with nets, or in weirs and traps, rudely constructed of twigs and brush" (Swan 1973 (1857):27). The weirs and traps described by Swan would have been appropriate methods along the north shore of the Columbia River, including Baker Bay which historically was part of a herring spawning area (Lassuy and Moran 1989: Figure 2), but not reported by Swan.

Gear free fishing. Swan also reported that the Indians took flat fish in the tidal shallows of Baker Bay. The Indians walked through the shallow waters pinning fish by stepping on them and tossing them onto dry ground (Swan 1973 (1857):83). 


\begin{tabular}{|c|c|c|c|c|c|c|c|c|c|c|}
\hline \multirow{5}{*}{ 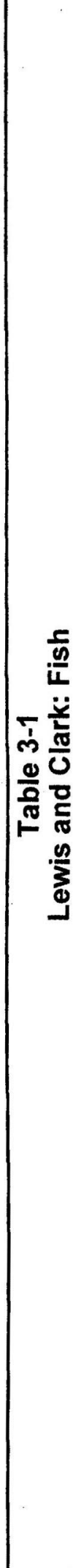 } & 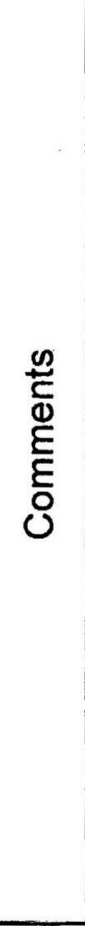 & 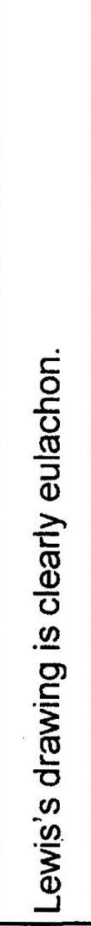 & 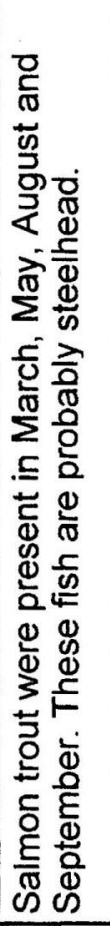 & 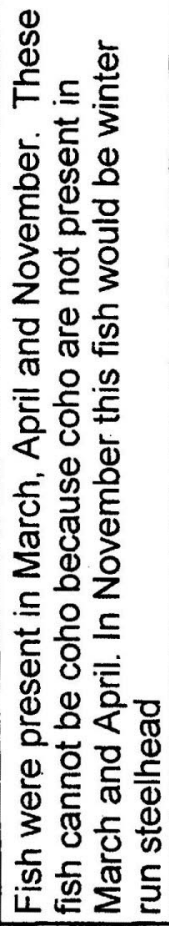 & 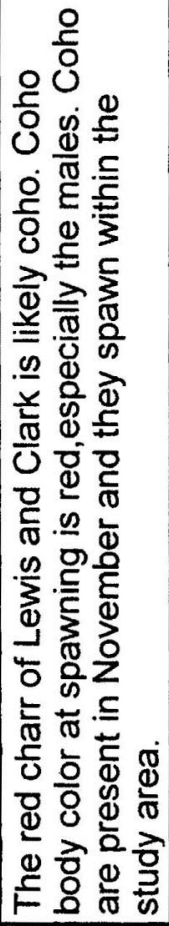 & 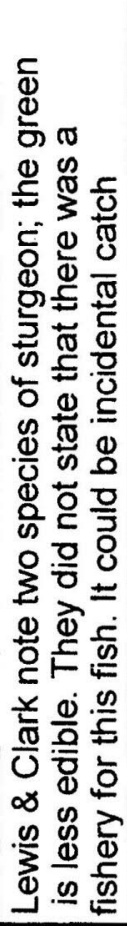 & 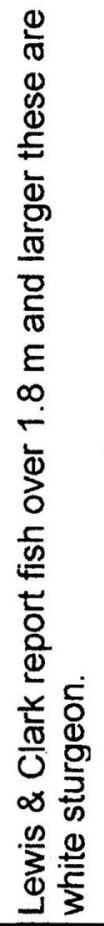 & 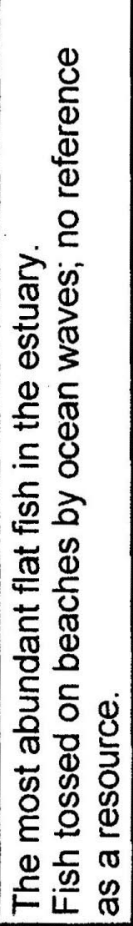 & 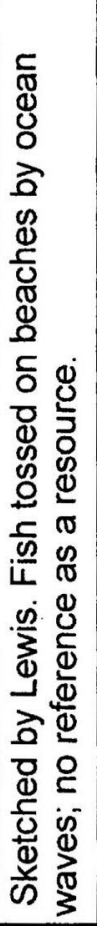 & 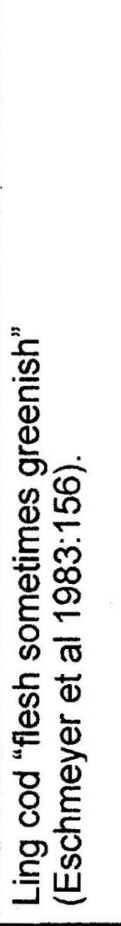 \\
\hline & 을 & 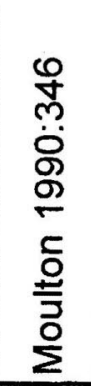 & 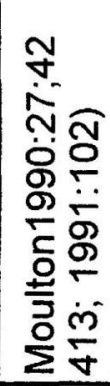 & 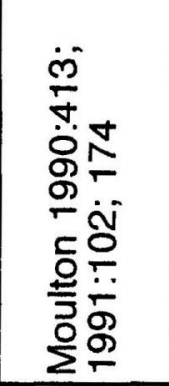 & 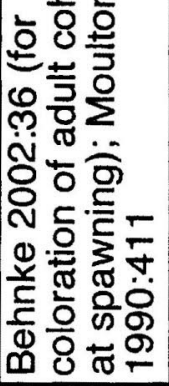 & 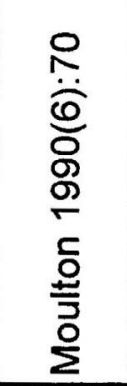 & 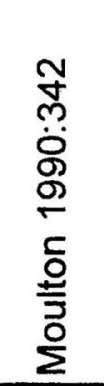 & 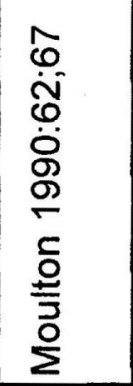 & 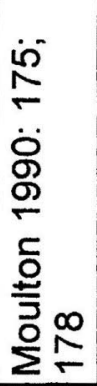 & 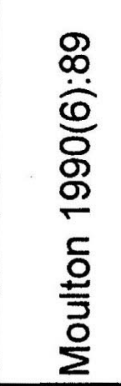 \\
\hline & $\begin{array}{l}0 \\
\frac{0}{0} \\
\Phi \\
0 \\
0 \\
\frac{0}{0} \\
\frac{1}{J}\end{array}$ & 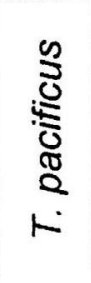 & $0^{\circ} \frac{\mathscr{c}}{\frac{c}{2}}$ & $\frac{\mathscr{y}}{\frac{n}{2}}$ & $\begin{array}{l}\frac{5}{ \pm} \\
\frac{5}{5} \\
0\end{array}$ & 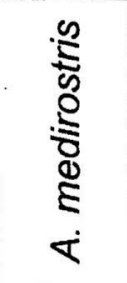 & 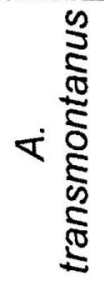 & 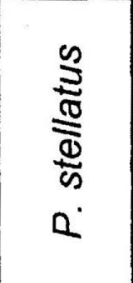 & $\begin{array}{l}\frac{\pi}{\pi} \\
\frac{0}{5} \\
0 \\
0 \\
\frac{5}{0} \\
\alpha\end{array}$ & 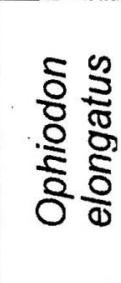 \\
\hline & 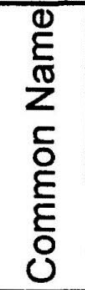 & 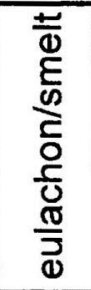 & 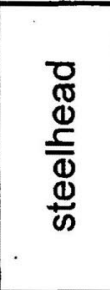 & 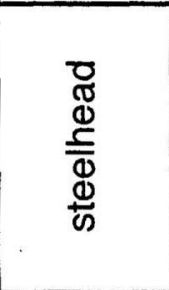 & 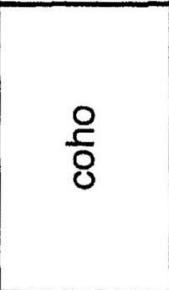 & 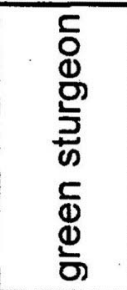 & 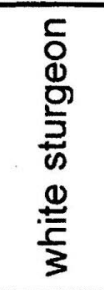 & $\begin{array}{l}\frac{1}{0} \\
\frac{0}{5} \\
\frac{0}{4} \\
\frac{2}{6} \\
\frac{\pi}{\infty}\end{array}$ & $\begin{array}{l}\frac{0}{\pi} \\
\frac{\Delta}{\omega} \\
\frac{0}{0}\end{array}$ & $\begin{array}{l}\text { 엄 } \\
\text { 읃 }\end{array}$ \\
\hline & 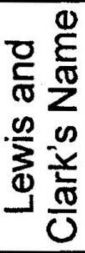 & 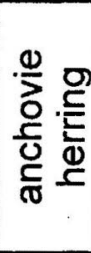 & 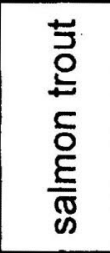 & 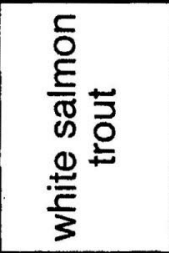 & $\begin{array}{l}\overline{0} \\
\frac{\sigma}{0} \\
\frac{0}{0}\end{array}$ & $\begin{array}{l}\overline{0} \\
\frac{d}{0} \\
\frac{7}{2}\end{array}$ & 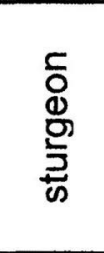 & $\begin{array}{l}\overline{0} \\
0 \\
\frac{0}{5} \\
0 \\
\frac{0}{6}\end{array}$ & $\begin{array}{l}\frac{1}{\infty} \\
\frac{1}{\Phi} \\
\Phi \\
\frac{1}{\infty}\end{array}$ & 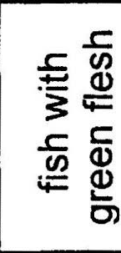 \\
\hline
\end{tabular}




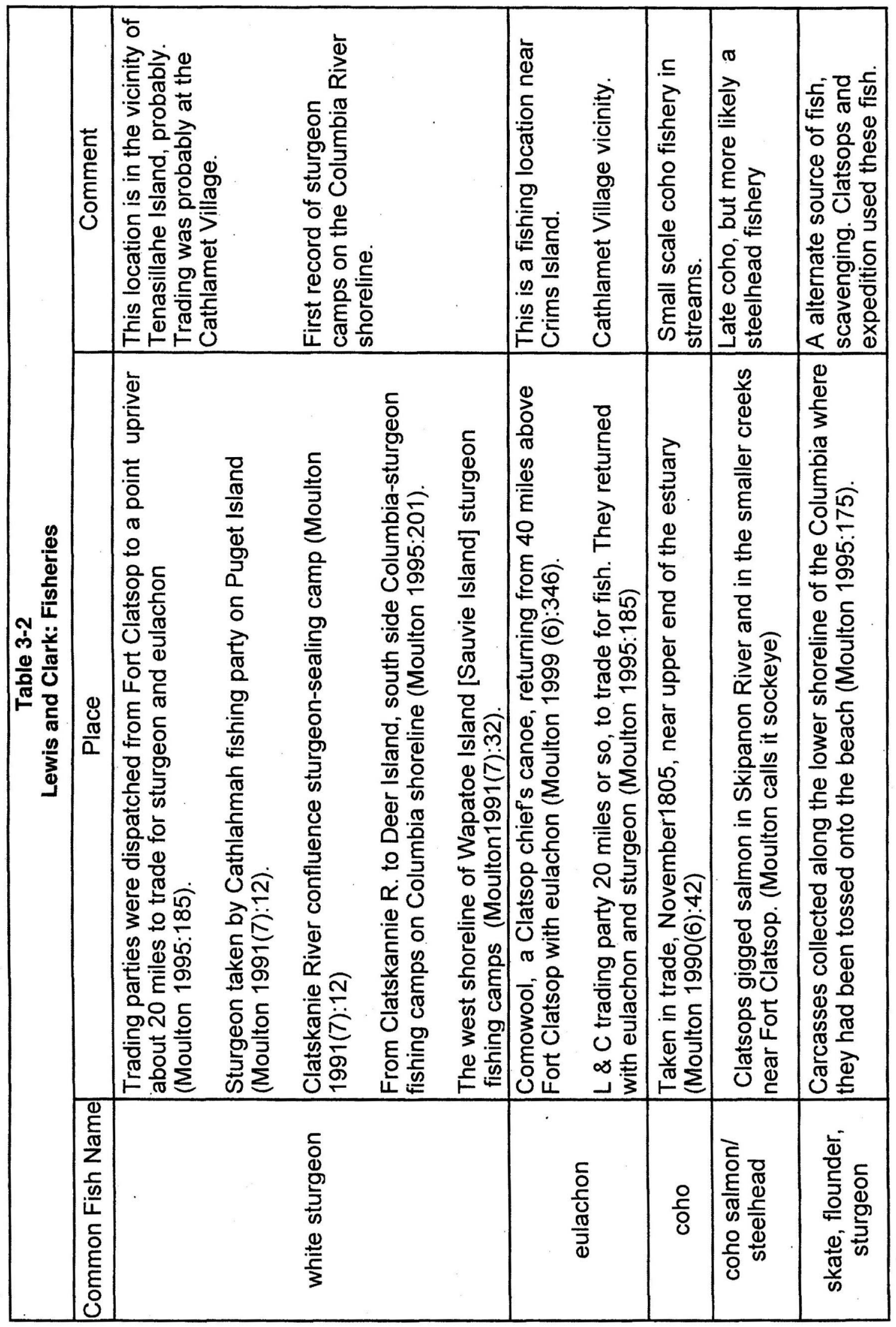




\begin{tabular}{|c|c|c|c|c|c|c|c|}
\hline \multirow{4}{*}{ 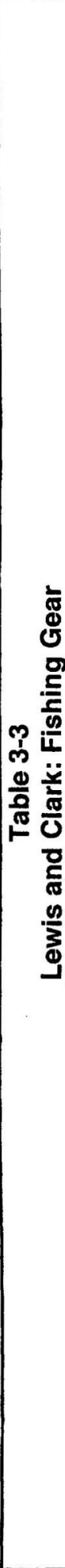 } & 蒿 & 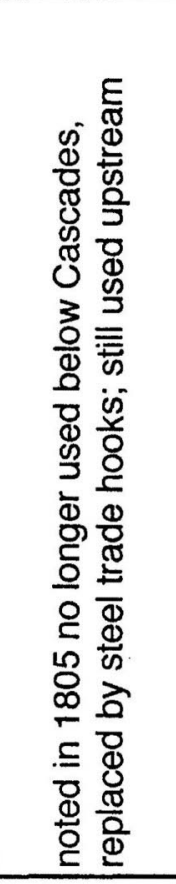 & 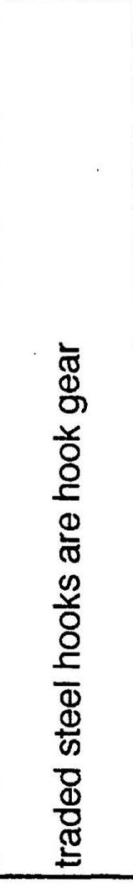 & 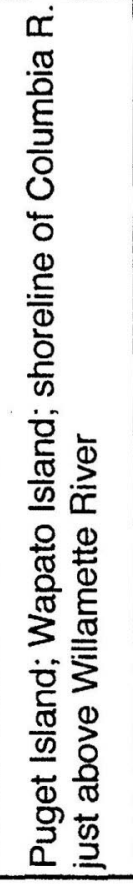 & 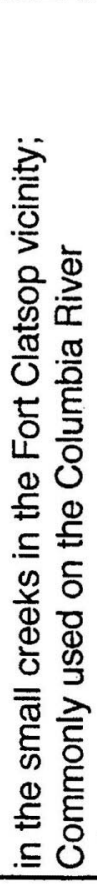 & 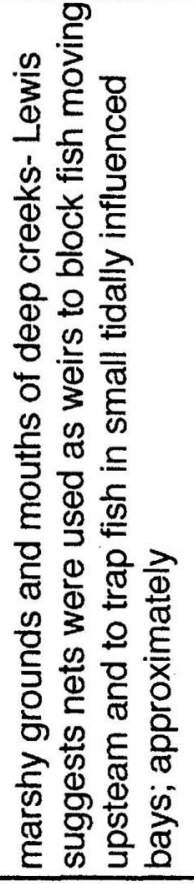 & 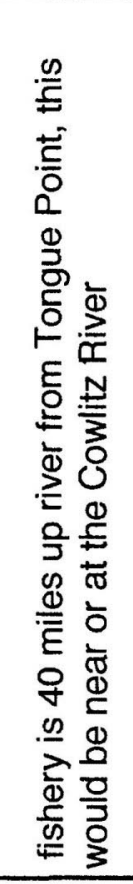 \\
\hline & $\begin{array}{l}\mathbb{d} \\
\mathbb{0} \\
\frac{\mathbb{0}}{2}\end{array}$ & 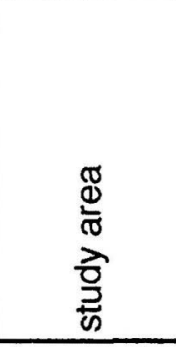 & 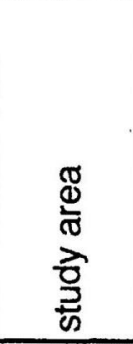 & $\begin{array}{l}\frac{\pi}{d} \\
\frac{1}{\pi} \\
\frac{7}{0} \\
\frac{2}{0}\end{array}$ & 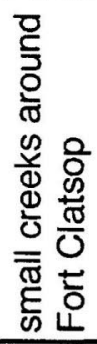 & 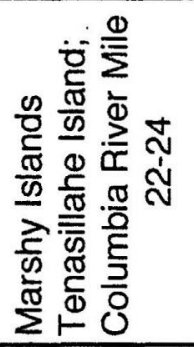 & 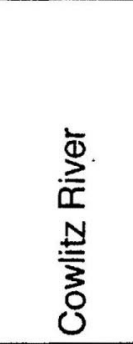 \\
\hline & $\begin{array}{l}\frac{c}{d} \\
\frac{\sqrt{\sigma}}{\sigma} \\
\frac{c}{\frac{\mathscr{D}}{L}}\end{array}$ & 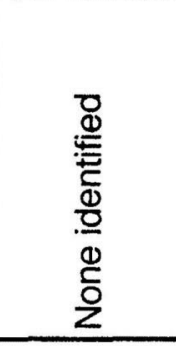 & 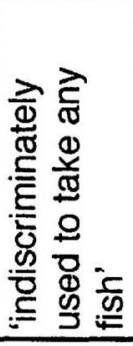 & 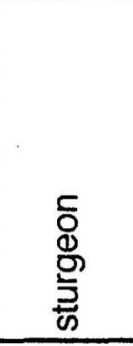 & 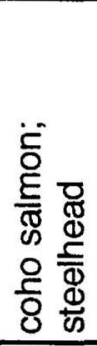 & 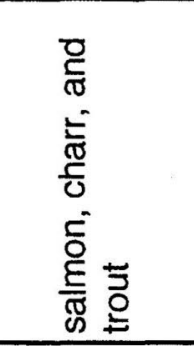 & 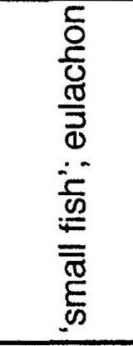 \\
\hline & $\begin{array}{l}\text { 跑 } \\
0 \\
0\end{array}$ & 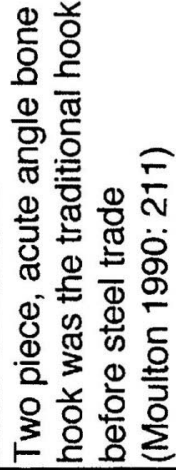 & 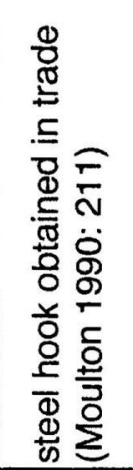 & 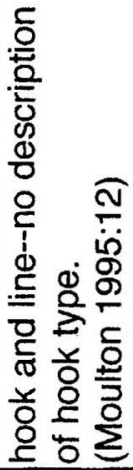 & 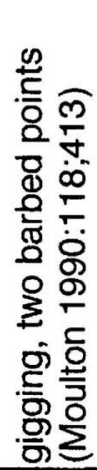 & 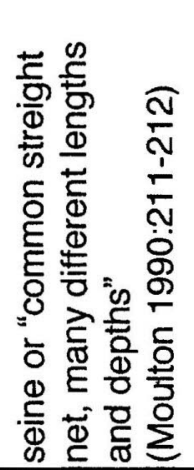 & 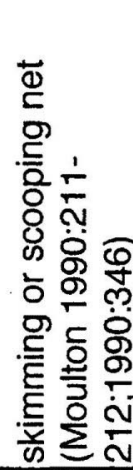 \\
\hline
\end{tabular}




\begin{tabular}{|c|c|c|c|c|c|c|c|c|}
\hline \multirow{5}{*}{ 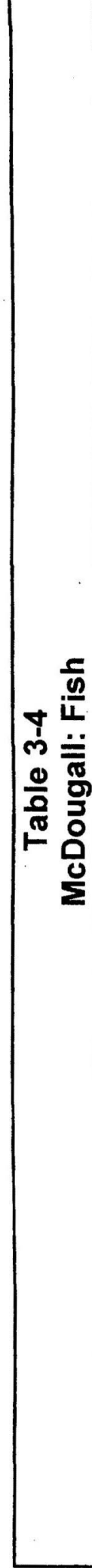 } & 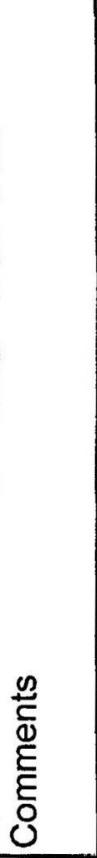 & 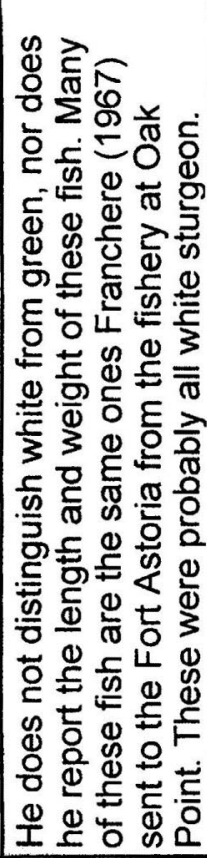 & 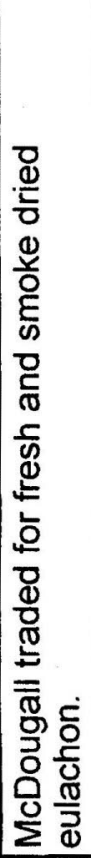 & 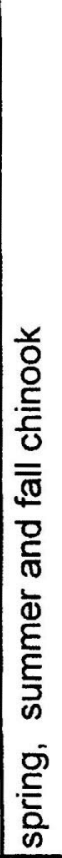 & 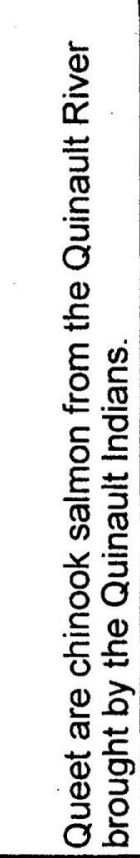 & 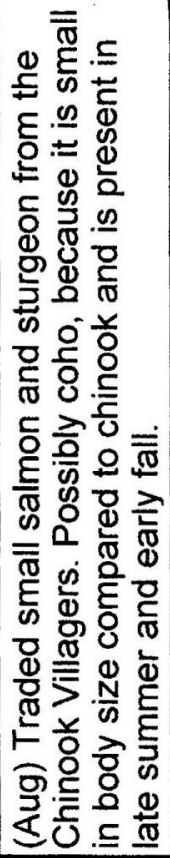 & 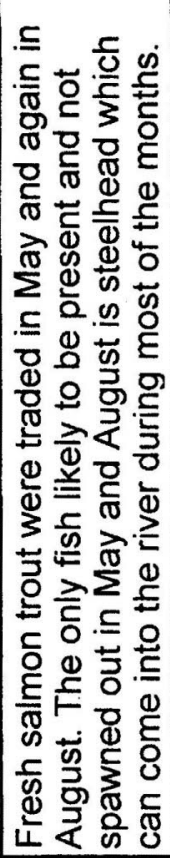 & 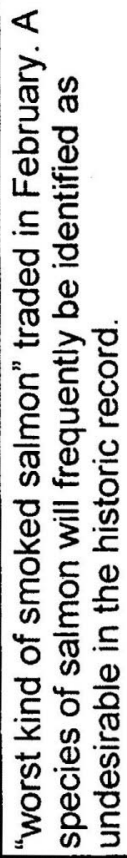 \\
\hline & 总 & 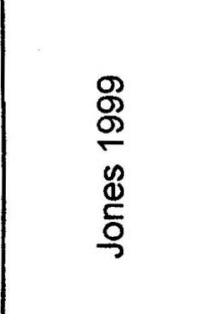 & 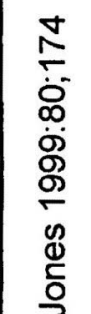 & & 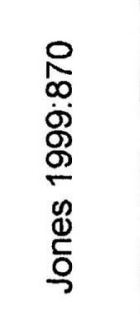 & 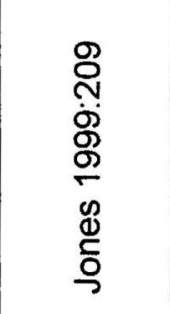 & 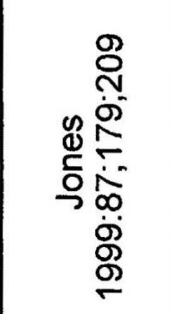 & 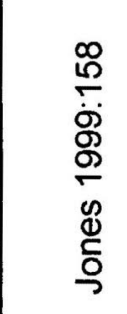 \\
\hline & $\begin{array}{l}\mathscr{d} \\
\frac{0}{0} \\
\Phi \\
\text { ஸू }\end{array}$ & 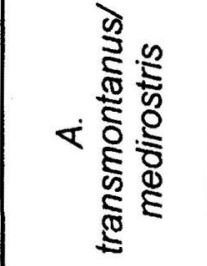 & 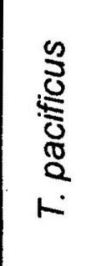 & & 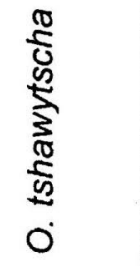 & $\begin{array}{l}\frac{5}{0} \\
\frac{5}{5} \\
\frac{0}{x} \\
0\end{array}$ & $\frac{\stackrel{n}{\mathscr{n}}}{\frac{\pi}{x}}$ & $\frac{\pi}{0}$ \\
\hline & 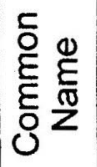 & 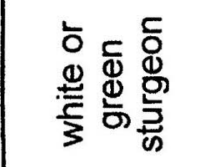 & 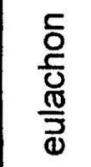 & & 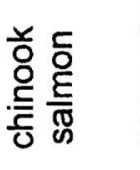 & 옹 & & 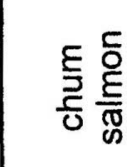 \\
\hline & 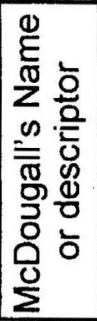 & $\begin{array}{l}\text { ᄃ } \\
0 \\
0 \\
\frac{7}{3}\end{array}$ & 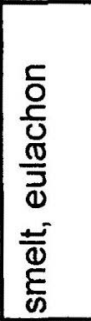 & $\frac{c}{\frac{c}{\delta}}$ & 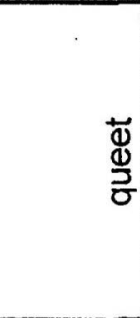 & $\frac{\frac{\mathrm{E}}{\sqrt{W}}}{\frac{\mathscr{N}}{\mathscr{N}}}$ & 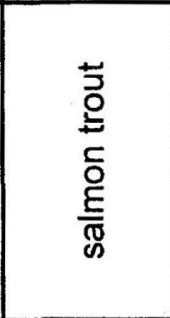 & 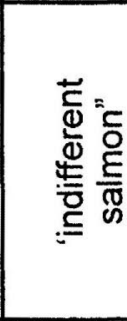 \\
\hline
\end{tabular}




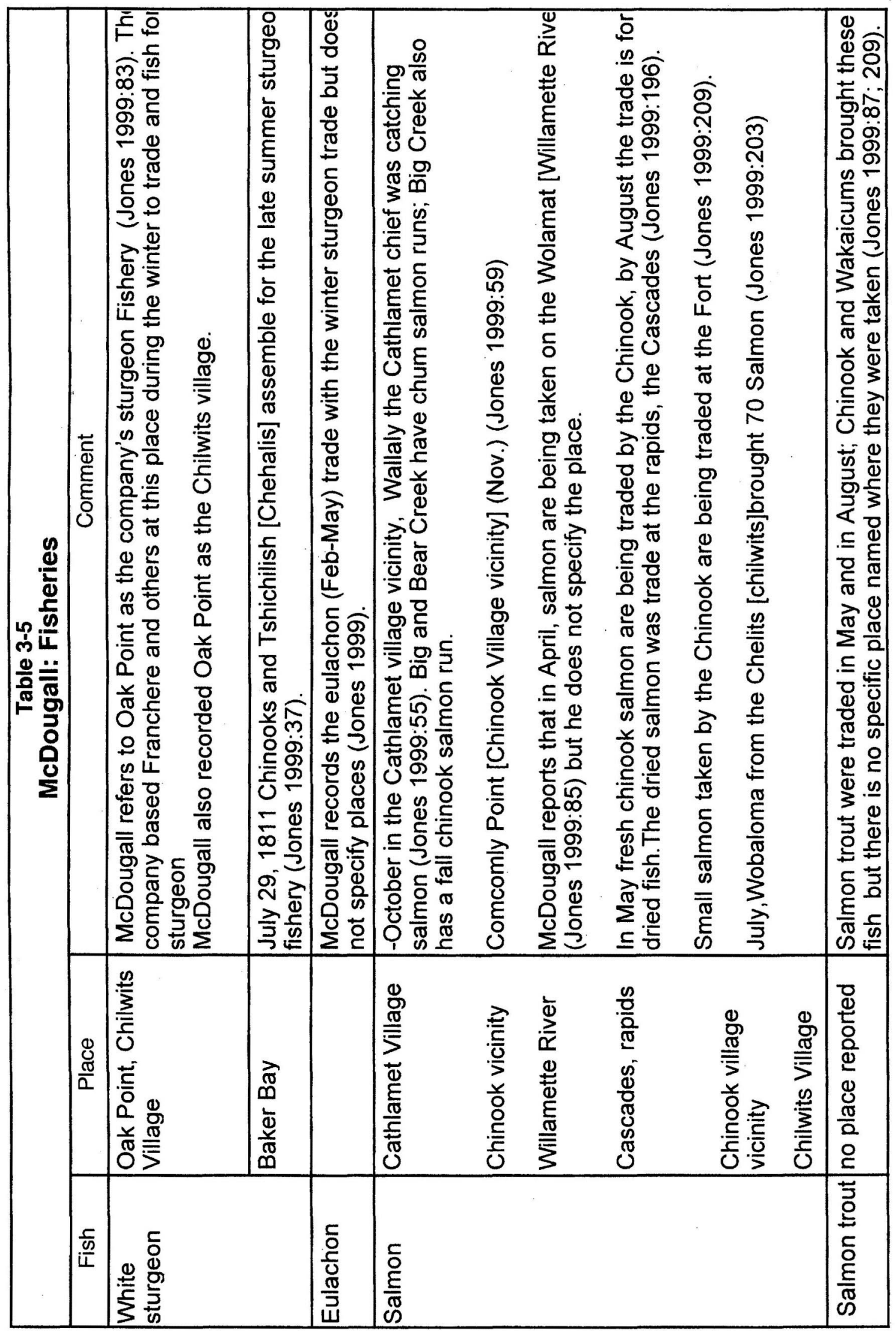




\begin{tabular}{|c|c|c|c|c|c|c|}
\hline 产 & 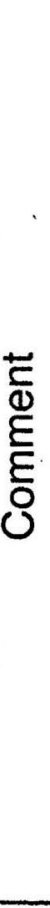 & 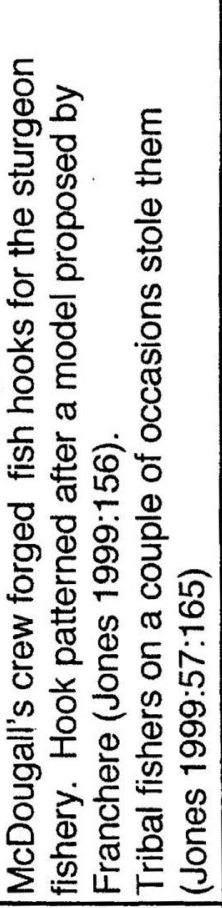 & 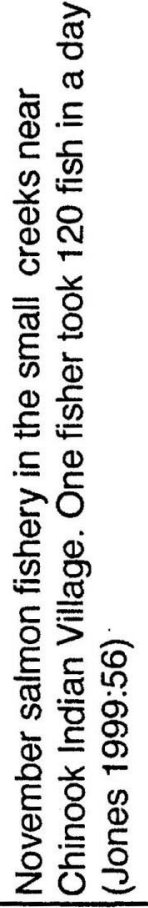 & 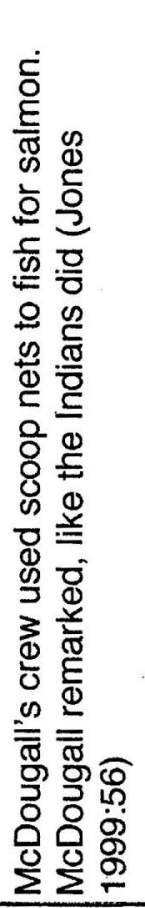 & 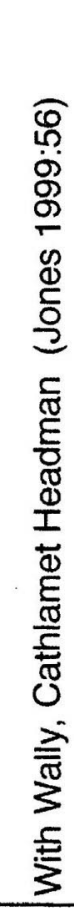 & 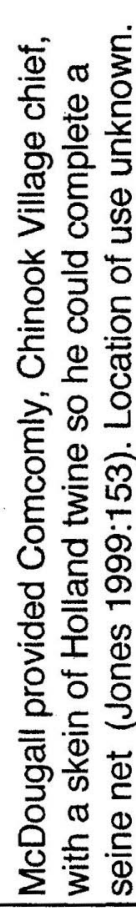 \\
\hline 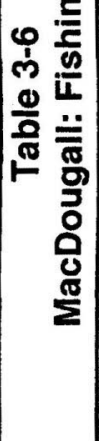 & $\begin{array}{l}\text { @ } \\
\mathbb{8} \\
\frac{\mathbb{x}}{\alpha}\end{array}$ & 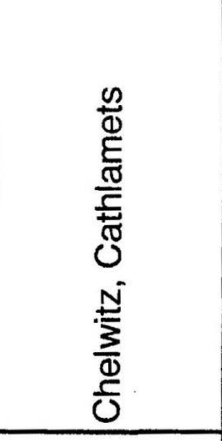 & 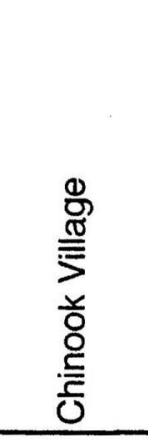 & 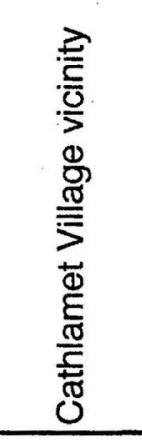 & 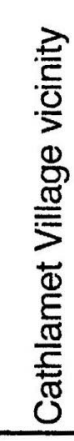 & 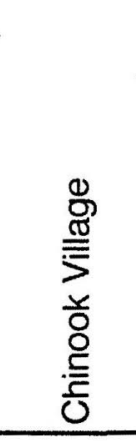 \\
\hline & 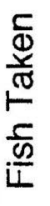 & 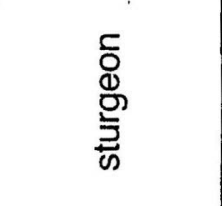 & 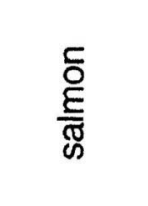 & $\frac{\text { ర్ }}{\text { हू }}$ & $\frac{\bar{\delta}}{\frac{\delta}{\widetilde{E}}}$ & $\frac{\bar{\delta}}{\frac{\bar{\delta}}{\overparen{E}}}$ \\
\hline & $\begin{array}{l}\text { ర్ } \\
\mathbb{\Phi} \\
\mathbb{0}\end{array}$ & 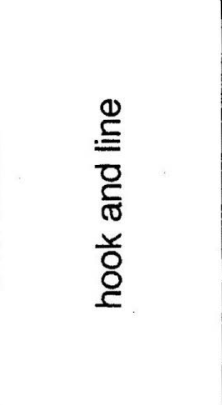 & 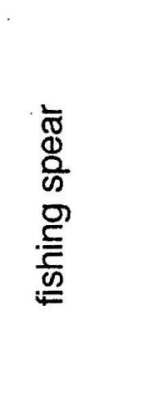 & 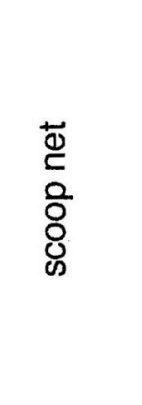 & 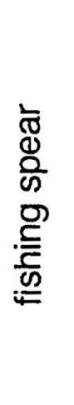 & 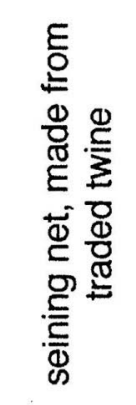 \\
\hline
\end{tabular}




\begin{tabular}{|c|c|c|c|c|c|c|}
\hline \multirow{5}{*}{ 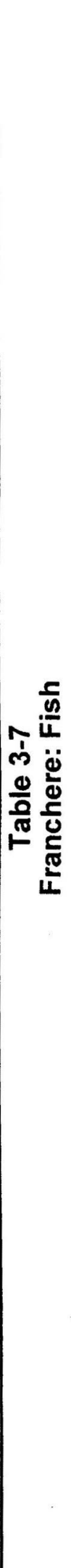 } & 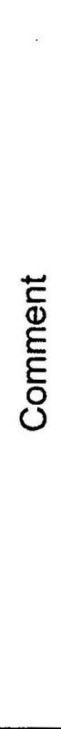 & 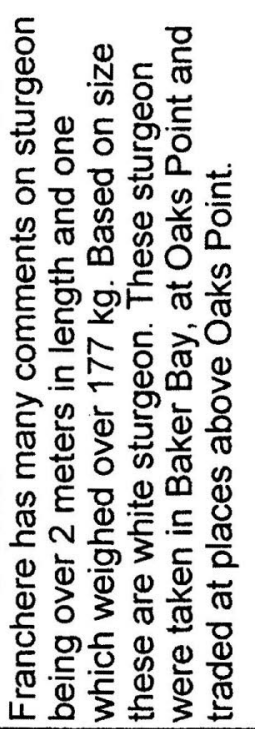 & 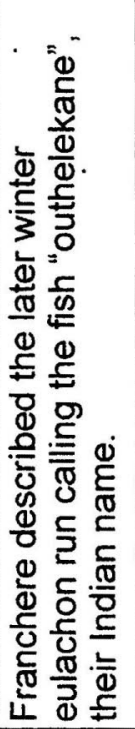 & 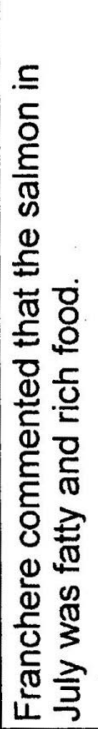 & 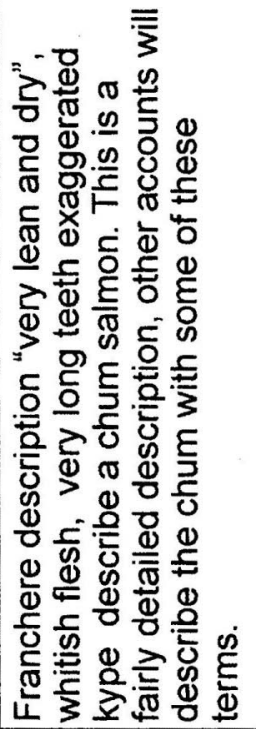 & 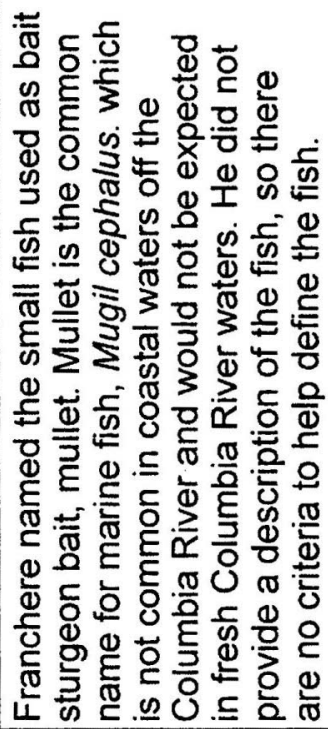 \\
\hline & 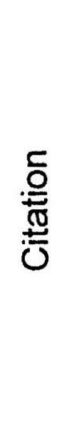 & 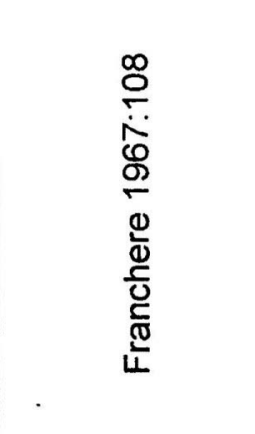 & 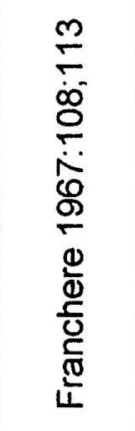 & 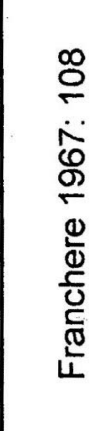 & 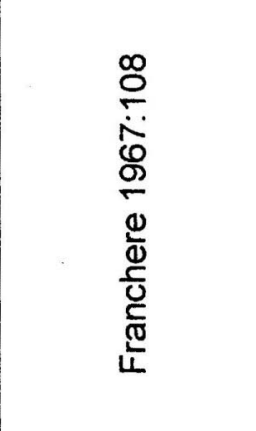 & 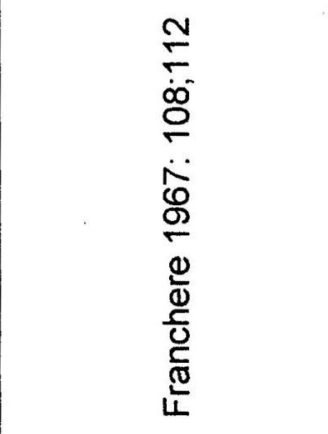 \\
\hline & $\begin{array}{l}\mathscr{W} \\
\frac{\mathbb{U}}{\Phi} \\
\text { 응 }\end{array}$ & 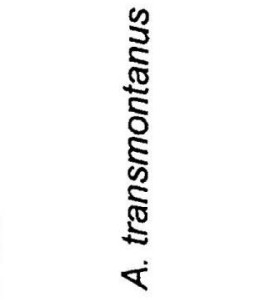 & 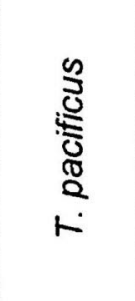 & 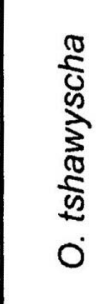 & $\frac{\mathbb{\pi}}{\mathbb{d}}$ & 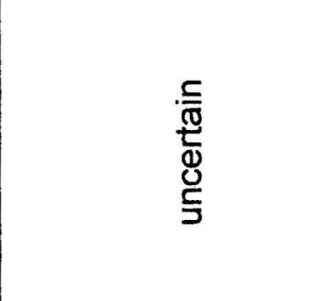 \\
\hline & 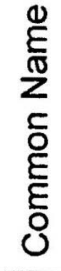 & 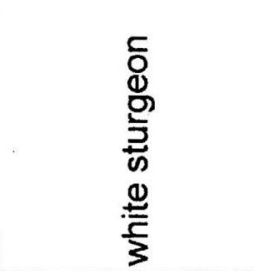 & $\begin{array}{l}\frac{ \pm}{0} \\
\frac{E}{0} \\
\frac{c}{0} \\
0 \\
\frac{c}{0} \\
\frac{0}{3}\end{array}$ & $\begin{array}{l}\text { 응 } \\
\text { 응 } \\
\text { 엉 }\end{array}$ & 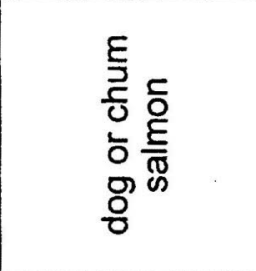 & $\begin{array}{l}. \frac{5}{10} \\
\frac{t}{0} \\
0 \\
\frac{5}{J}\end{array}$ \\
\hline & 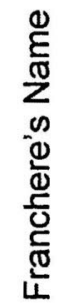 & 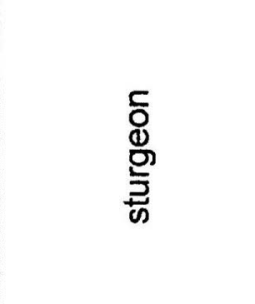 & है & $\frac{\overline{\underline{E}}}{\overline{\mathscr{C}}}$ & 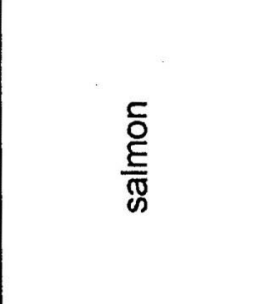 & 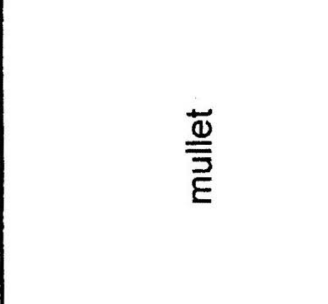 \\
\hline
\end{tabular}




\begin{tabular}{|c|c|c|c|c|c|c|c|}
\hline \multirow{3}{*}{ 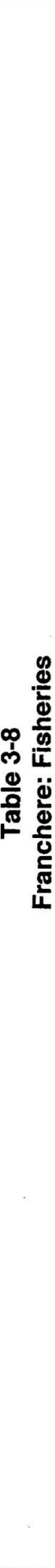 } & 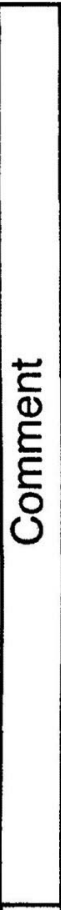 & & 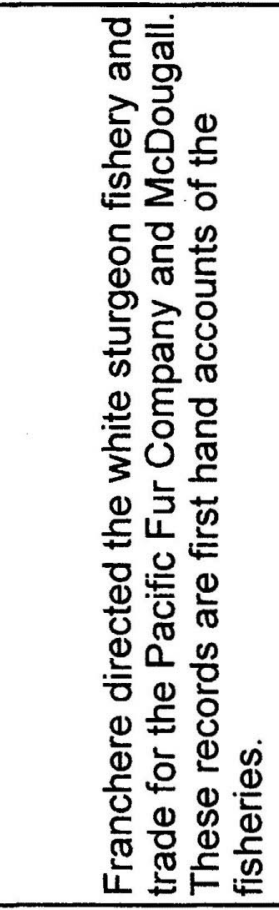 & & 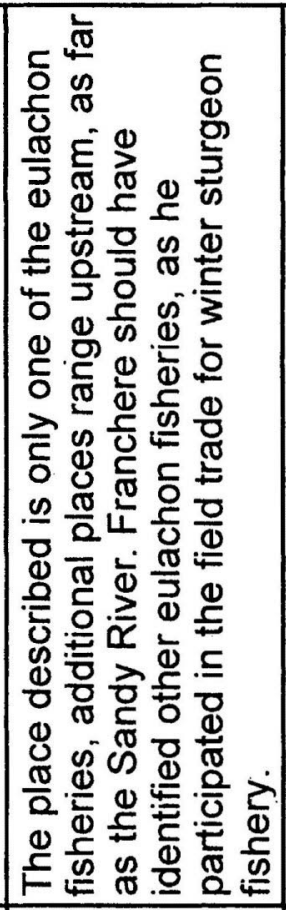 & 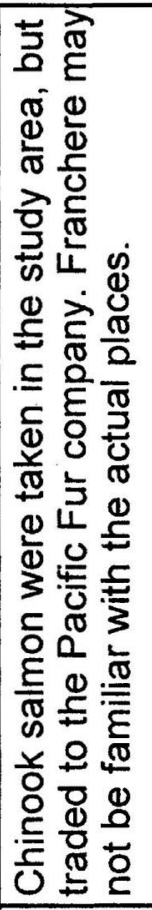 & 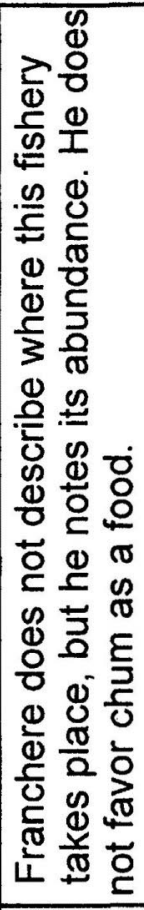 \\
\hline & 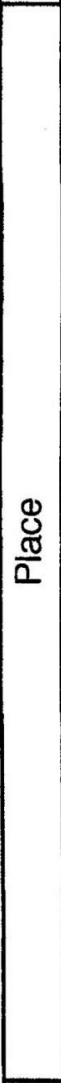 & 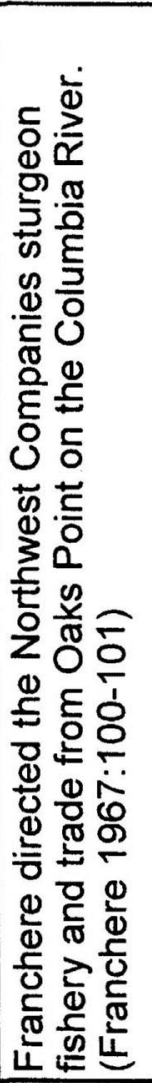 & 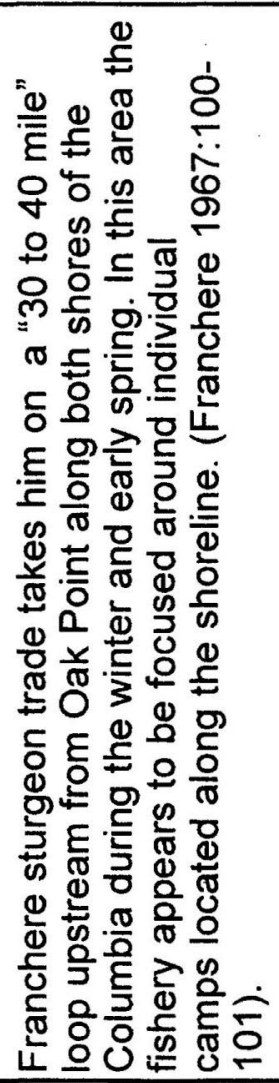 & 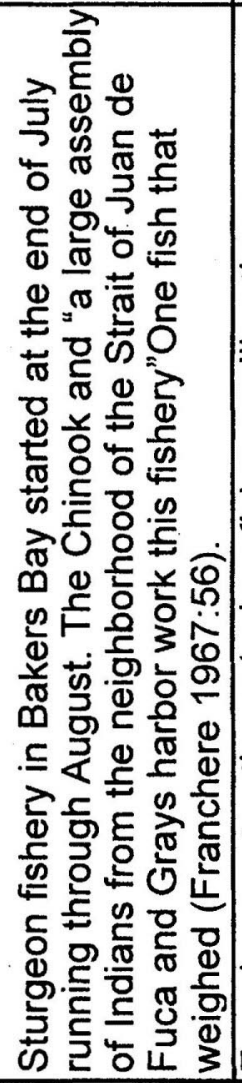 & 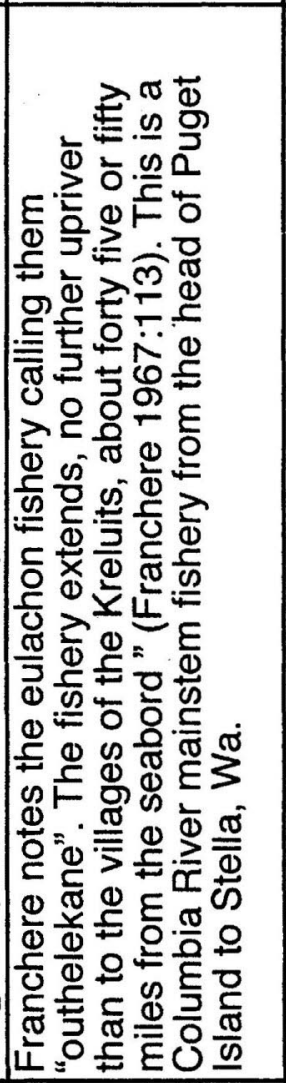 & 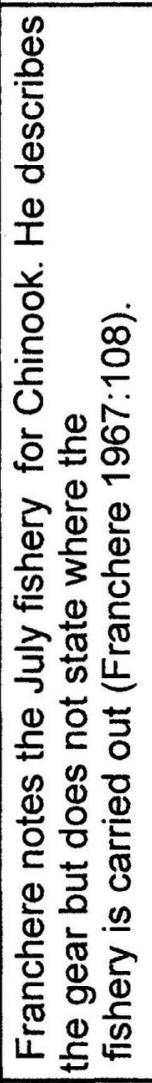 & 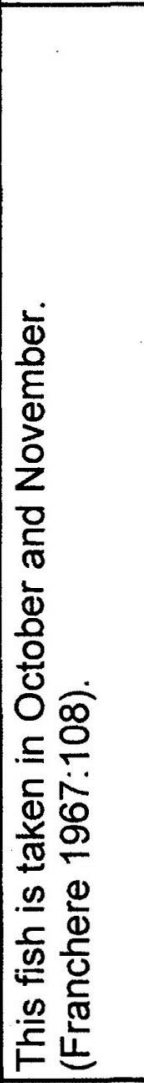 \\
\hline & $\frac{\frac{5}{5}}{\frac{1}{1}}$ & 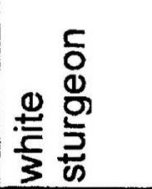 & & & 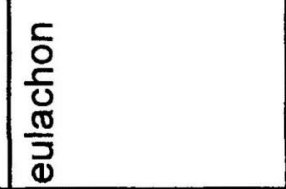 & 을 $\frac{0}{\mathrm{C}}$ & 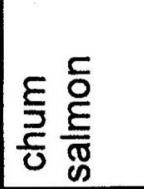 \\
\hline
\end{tabular}




\begin{tabular}{|c|c|c|c|c|c|c|c|}
\hline \multirow{5}{*}{ 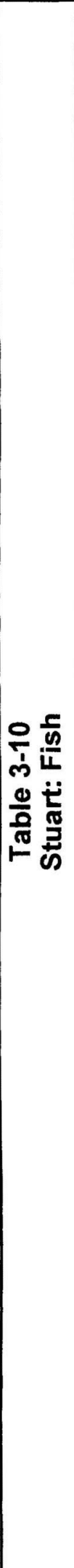 } & 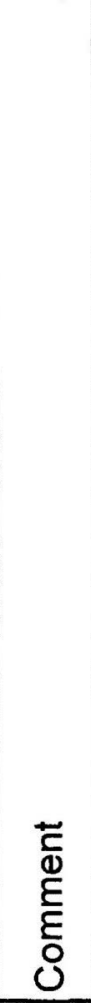 & 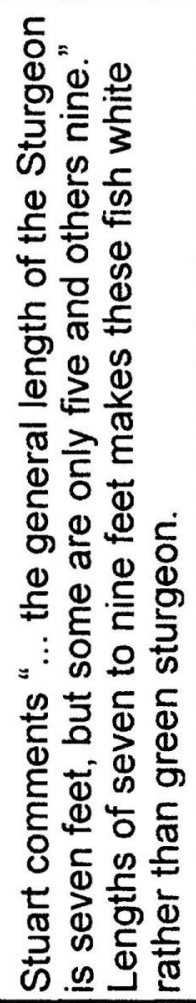 & 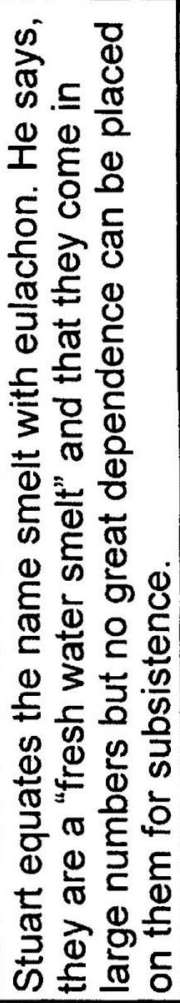 & 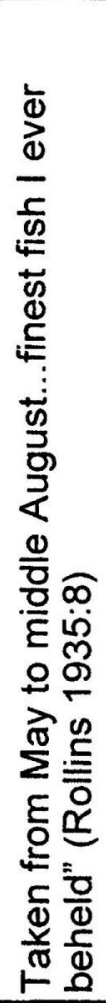 & 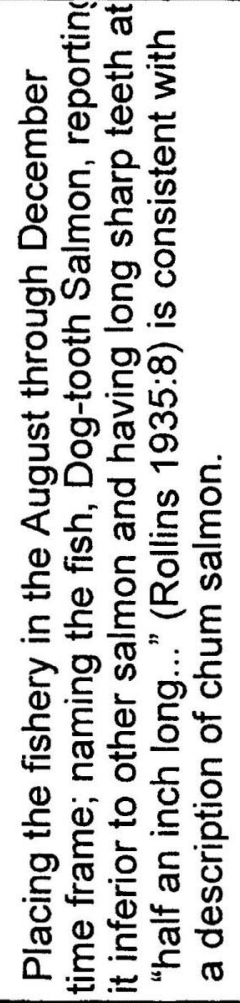 & 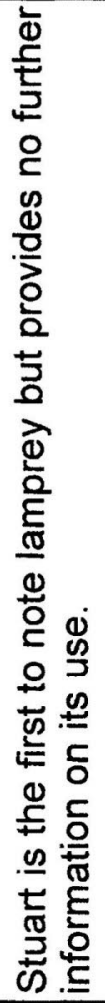 & 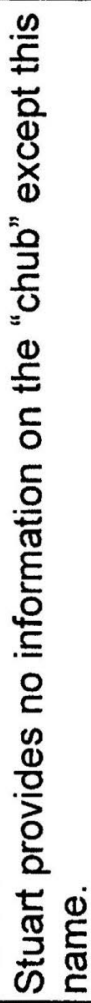 \\
\hline & 它 & 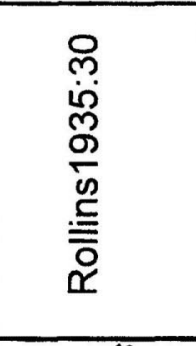 & 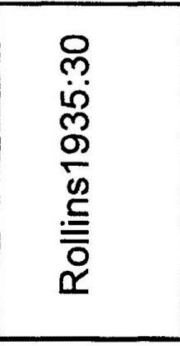 & 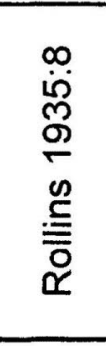 & 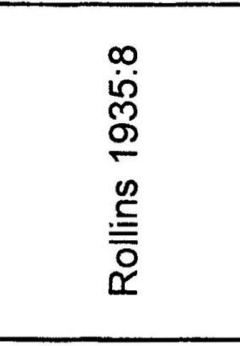 & 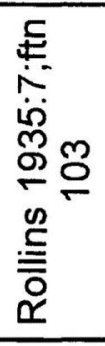 & 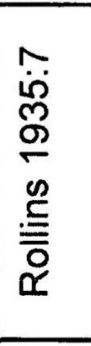 \\
\hline & $\begin{array}{l}\mathscr{d} \\
\frac{0}{0} \\
\searrow \\
0 \\
0\end{array}$ & 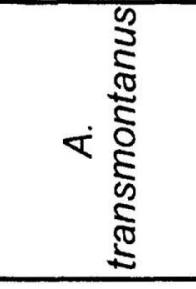 & 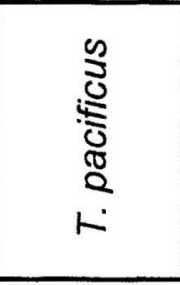 & 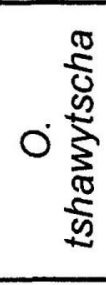 & 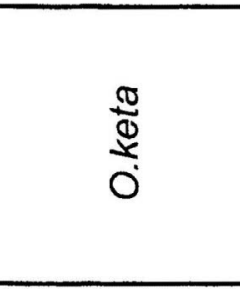 & 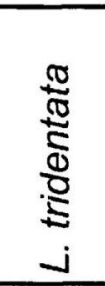 & $\begin{array}{l}\frac{5}{3} \\
\text { Dे } \\
\frac{5}{5} \\
\text { c }\end{array}$ \\
\hline & 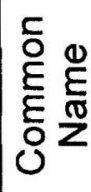 & 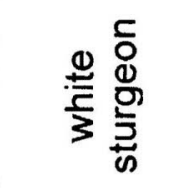 & $\begin{array}{l}\text { 든 } \\
\frac{0}{0} \\
\frac{\mathbb{0}}{7} \\
\frac{1}{0}\end{array}$ & $\begin{array}{l}\text { 응 } \\
\text { 응 }\end{array}$ & $\frac{E}{\frac{E}{3}}$ & 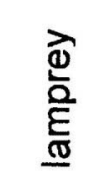 & ํㅗㄴ \\
\hline & 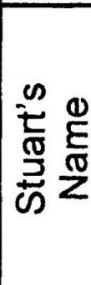 & 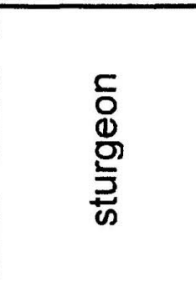 & 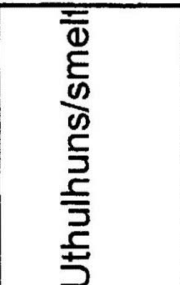 & $\frac{\overline{\mathrm{E}}}{\stackrel{\mathrm{E}}{\overparen{W}}}$ & 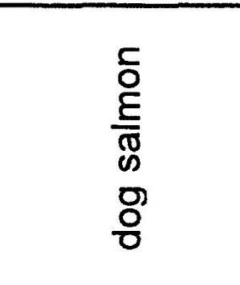 & $\begin{array}{l}\stackrel{\Phi}{0} \\
\text { ్ㅇㅇ }\end{array}$ & $\frac{\vec{c}}{\mathcal{U}}$ \\
\hline
\end{tabular}




\begin{tabular}{|c|c|c|c|c|c|c|}
\hline \multirow{4}{*}{ 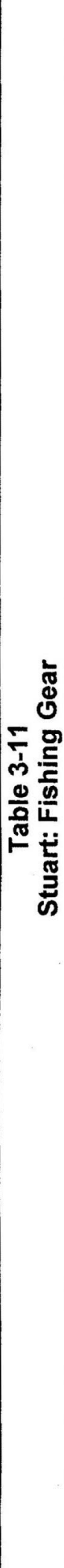 } & 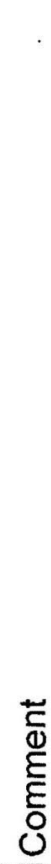 & 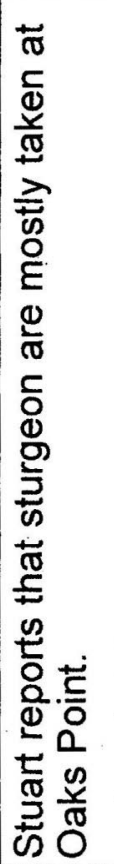 & 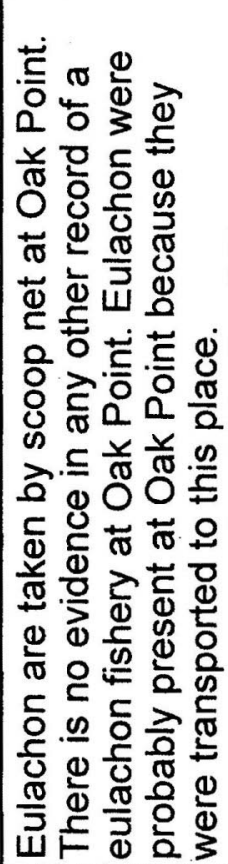 & 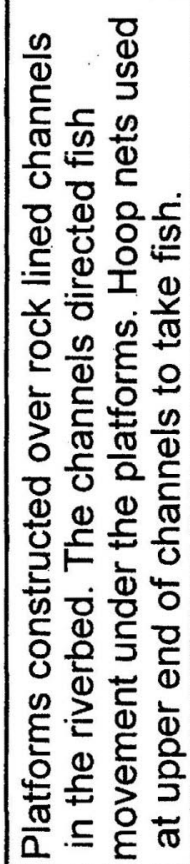 & 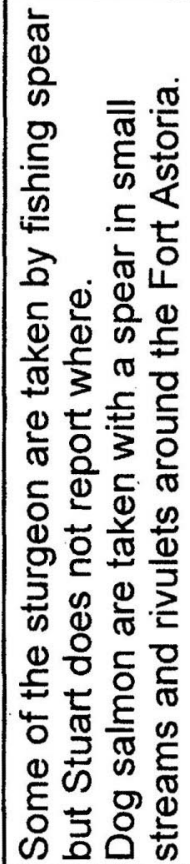 & 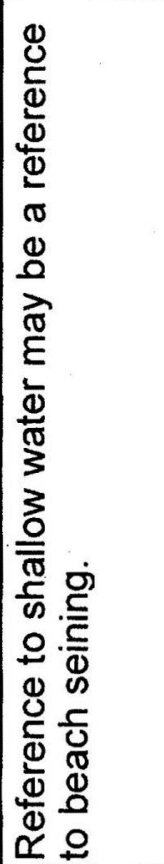 \\
\hline & $\begin{array}{l}\mathscr{d} \\
\stackrel{\mathbb{Z}}{\alpha} \\
\frac{\pi}{2}\end{array}$ & 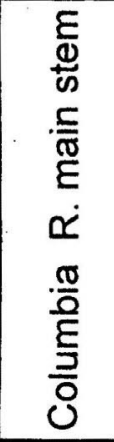 & 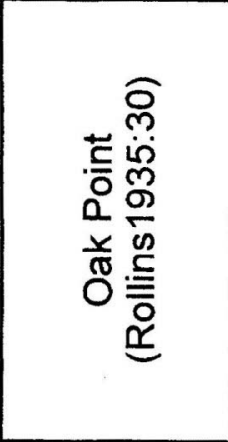 & 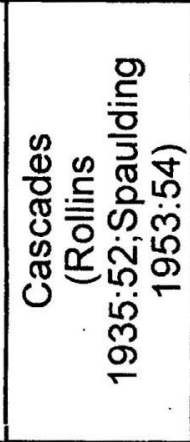 & 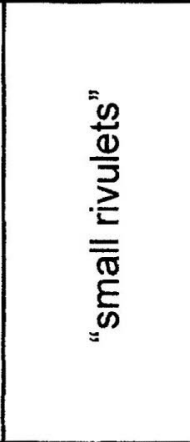 & 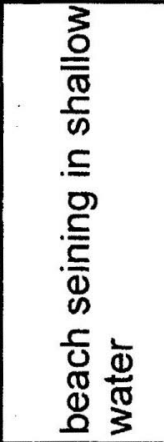 \\
\hline & $\frac{\frac{c}{d}}{\frac{v}{D}}$ & 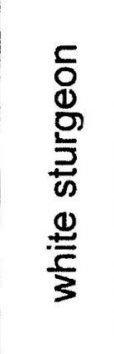 & 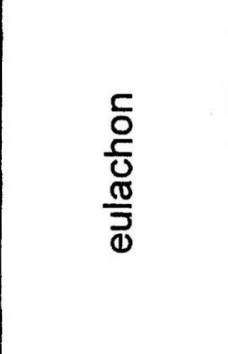 & $\frac{\frac{c}{0}}{\stackrel{E}{E}}$ & 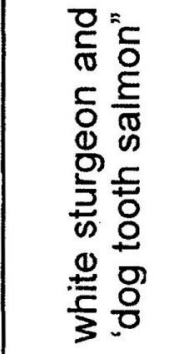 & 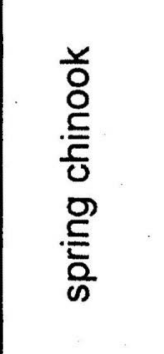 \\
\hline & $\begin{array}{l}\overline{0} \\
\mathbb{0}\end{array}$ & 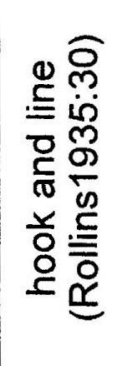 & 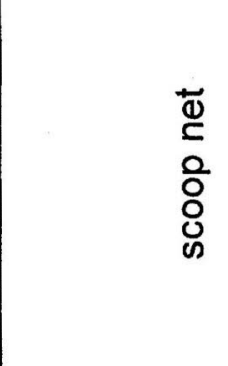 & & 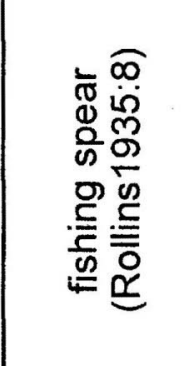 & 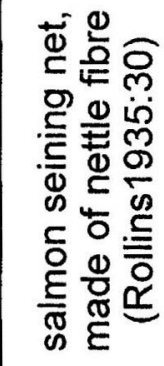 \\
\hline
\end{tabular}




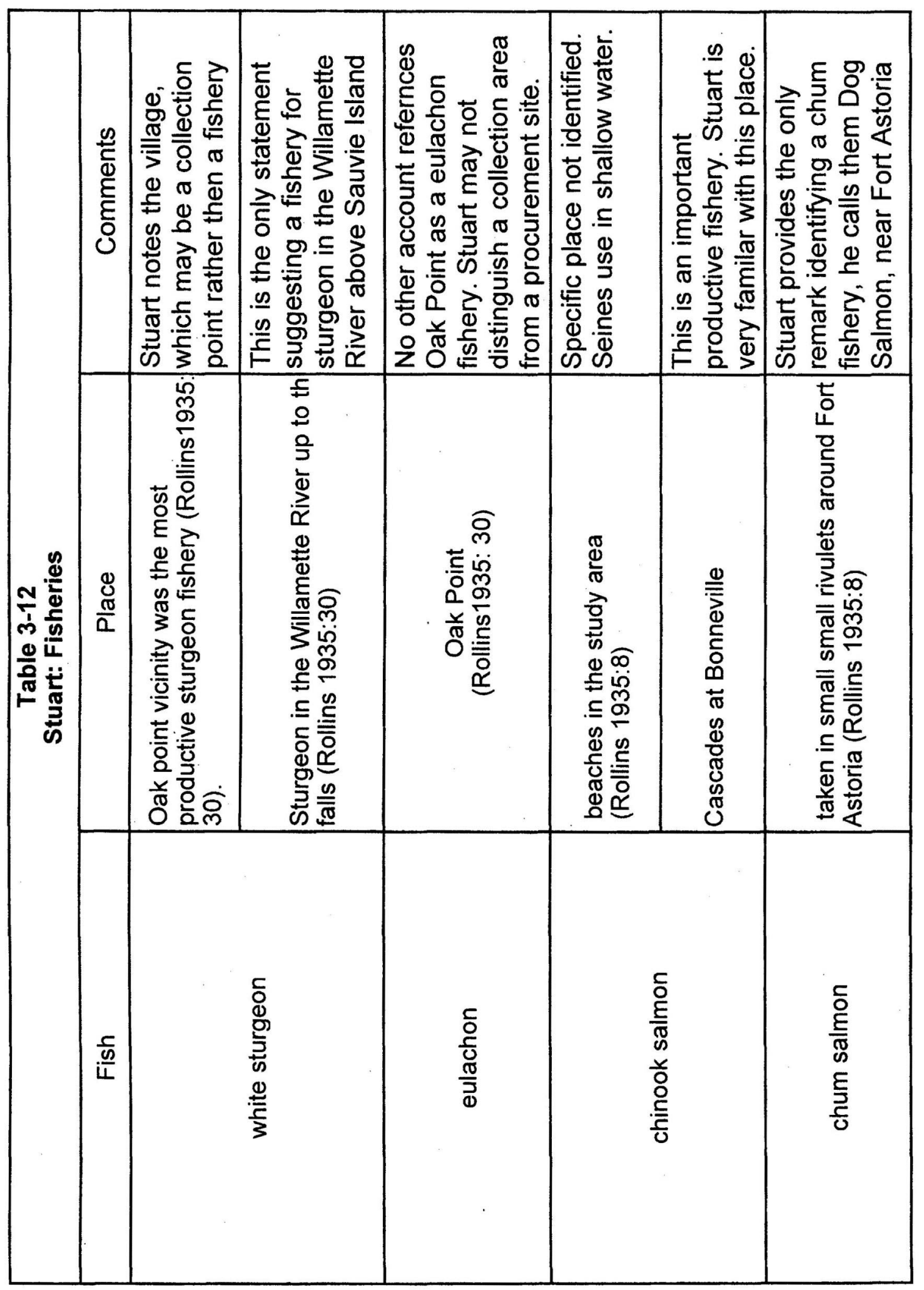




\begin{tabular}{|c|c|c|c|c|c|c|c|}
\hline \multirow{5}{*}{ 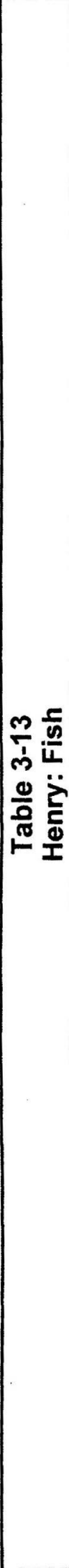 } & 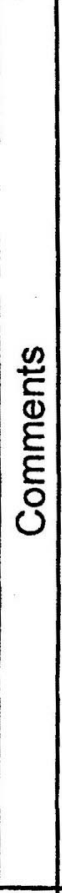 & 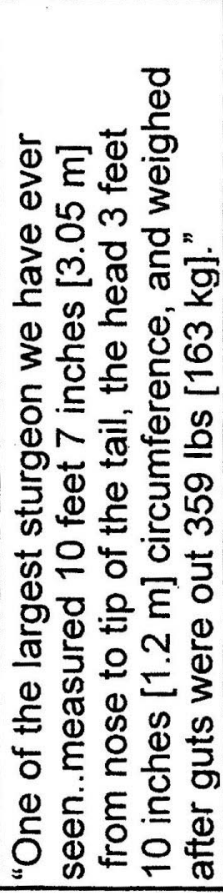 & 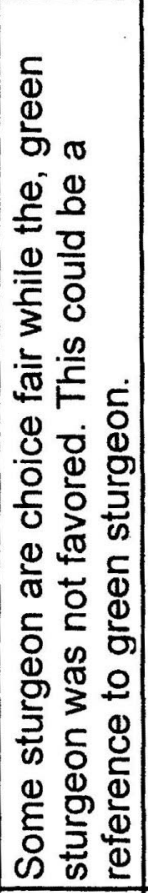 & 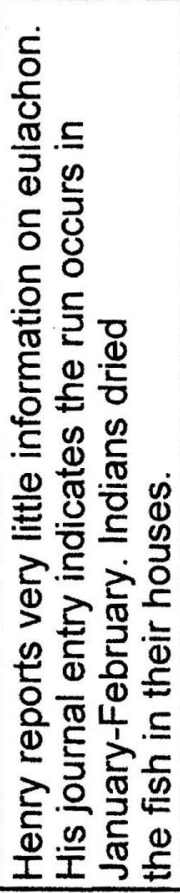 & 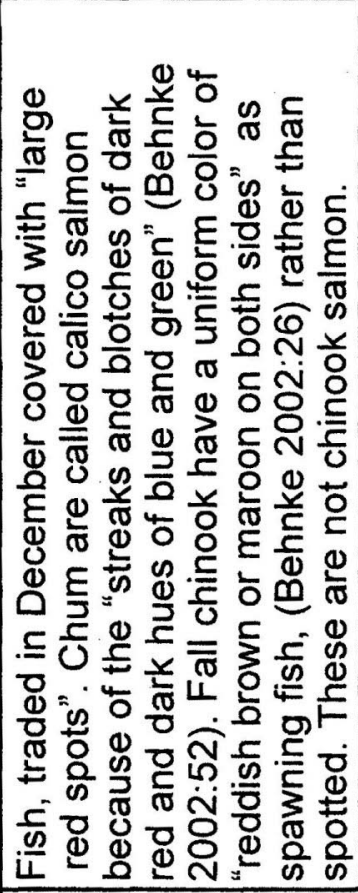 & 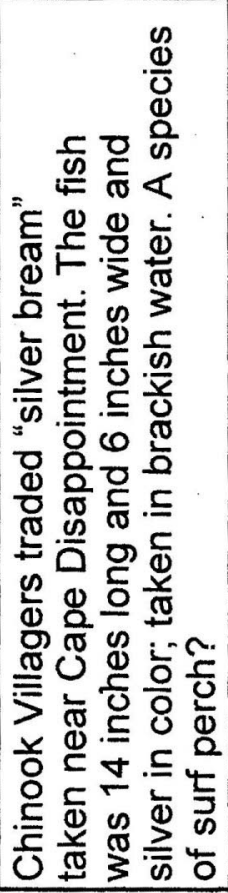 & 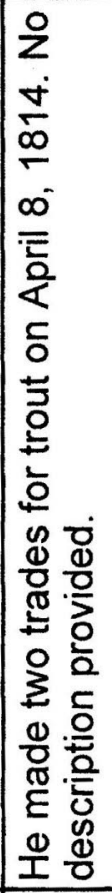 \\
\hline & 䆙 & 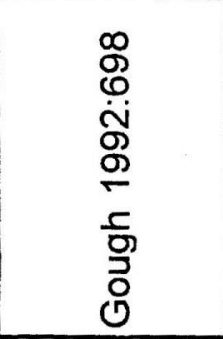 & 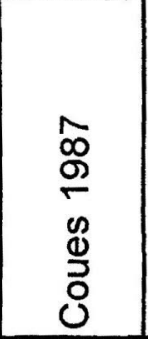 & 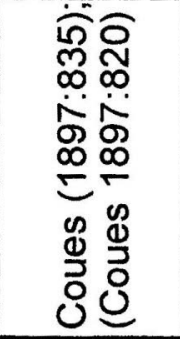 & 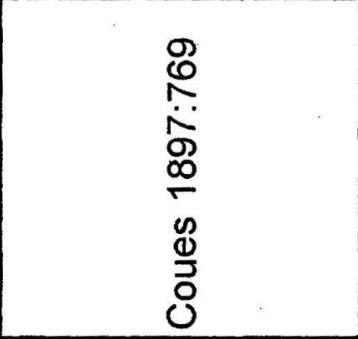 & 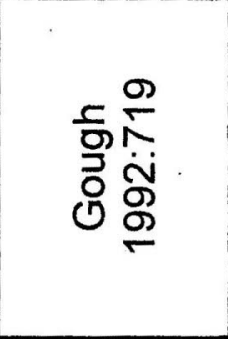 & 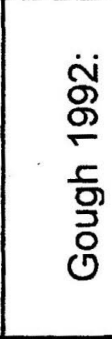 \\
\hline & $\begin{array}{l}\mathscr{\Phi} \\
\cdot \frac{1}{0} \\
\Phi \\
\text { 응 }\end{array}$ & 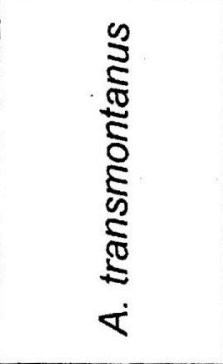 & 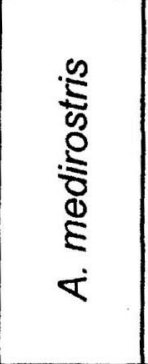 & 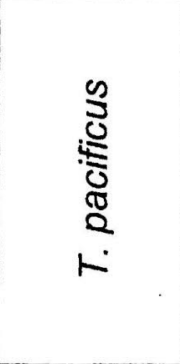 & 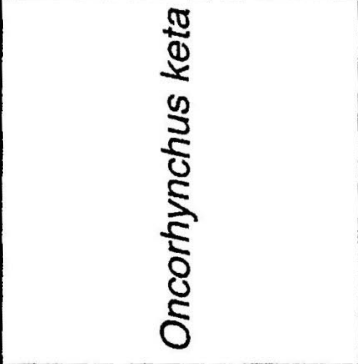 & 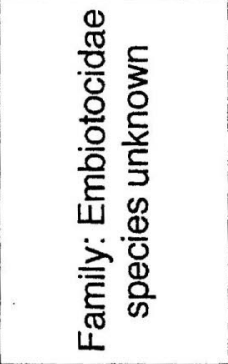 & 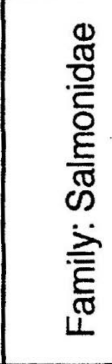 \\
\hline & 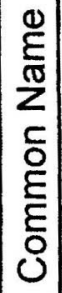 & 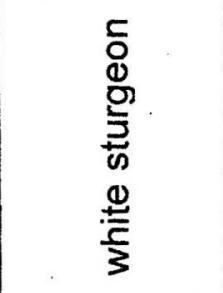 & 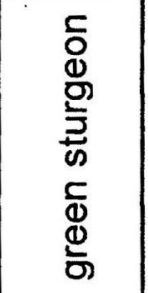 & $\begin{array}{l}\frac{c}{0} \\
\frac{c}{0} \\
\frac{\pi}{3} \\
\frac{1}{10}\end{array}$ & 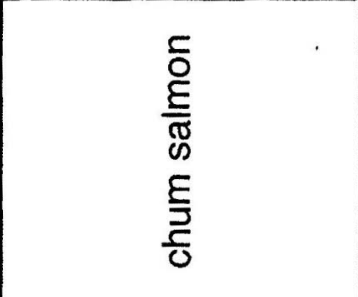 & 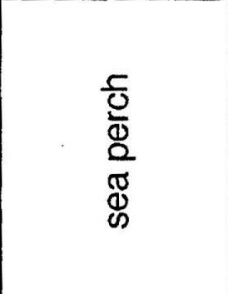 & 늘 \\
\hline & $\begin{array}{l}\frac{D}{E} \\
\frac{D}{D} \\
Z \\
0 \\
Z \\
\frac{Z}{0} \\
\frac{1}{1} \\
\end{array}$ & 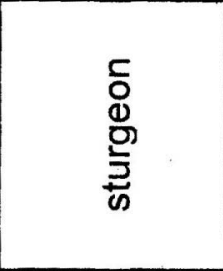 & $\begin{array}{l}5 \\
\frac{5}{0} \\
\frac{0}{3} \\
\frac{7}{0}\end{array}$ & 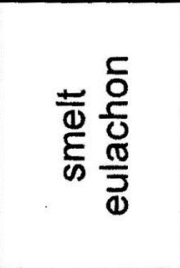 & 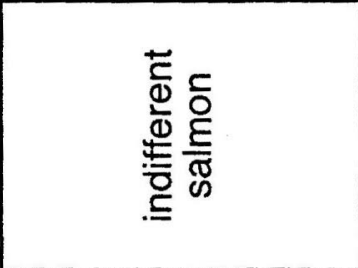 & 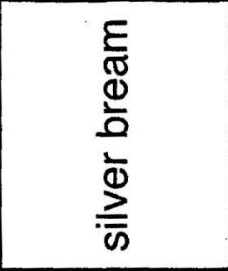 & 苛 \\
\hline
\end{tabular}




\begin{tabular}{|c|c|c|c|c|c|c|c|c|c|}
\hline \multirow[t]{3}{*}{ 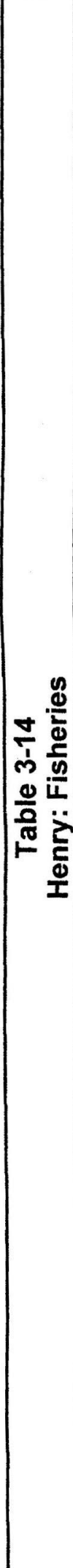 } & 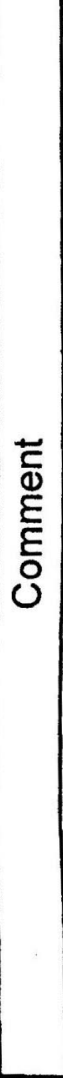 & 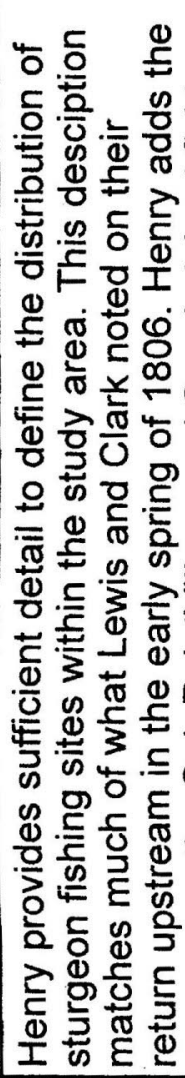 & 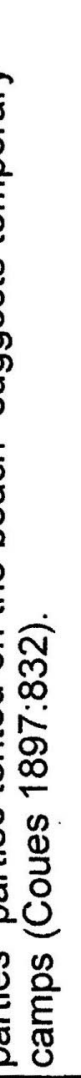 & 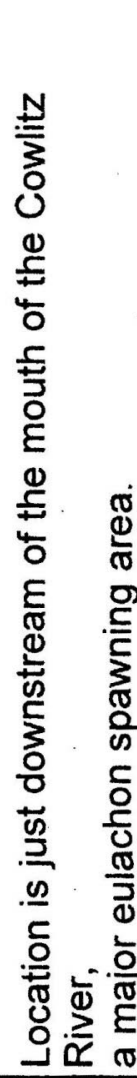 & 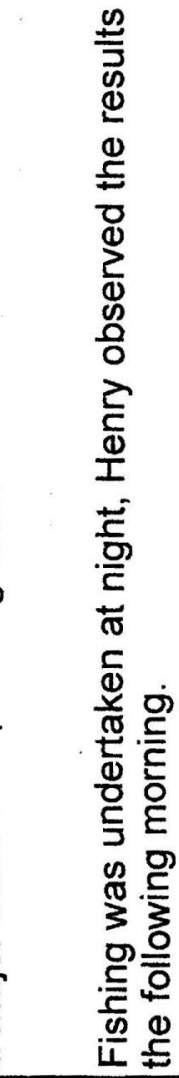 & 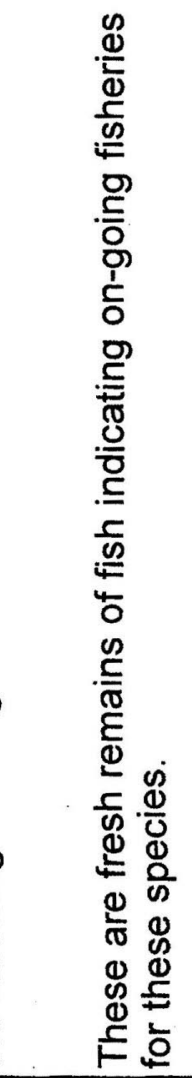 & 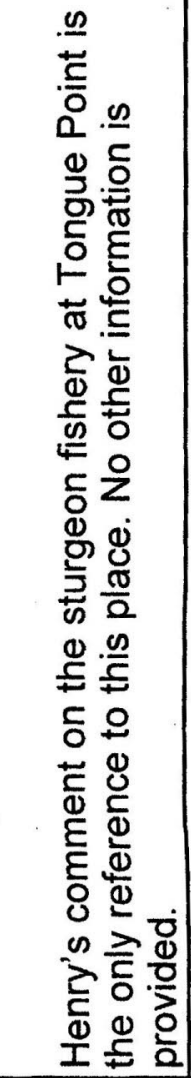 & 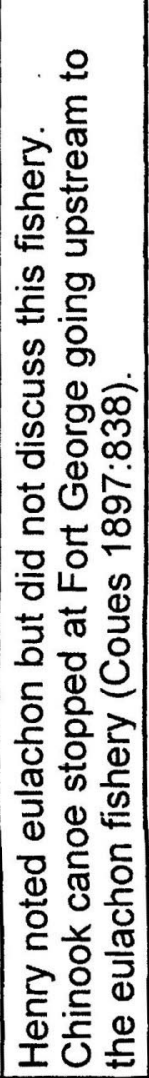 & 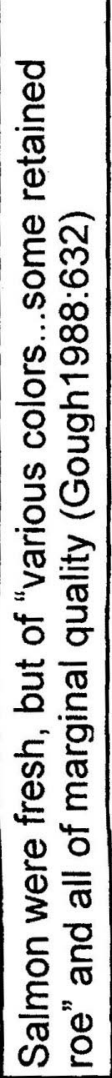 \\
\hline & $\begin{array}{l}\mathbb{E} \\
0 \\
\frac{\mathbb{Z}}{\square} \\
\end{array}$ & 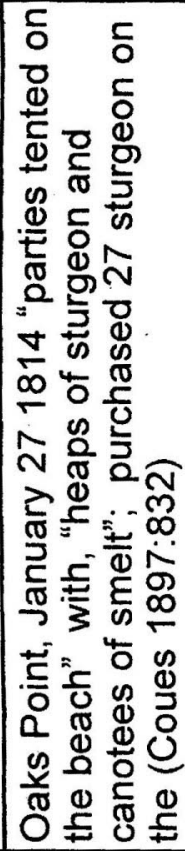 & 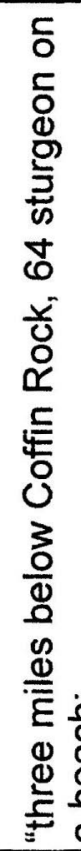 & 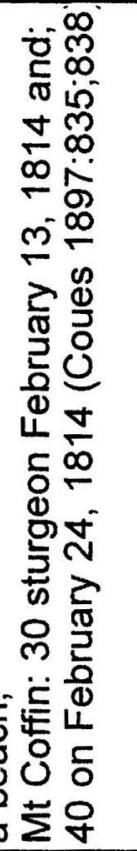 & 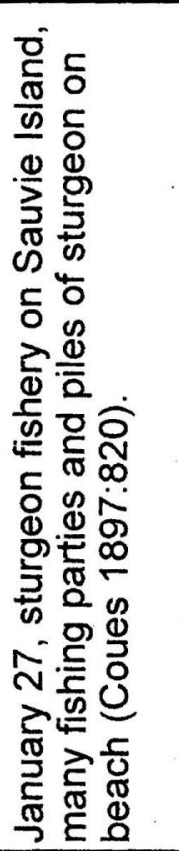 & 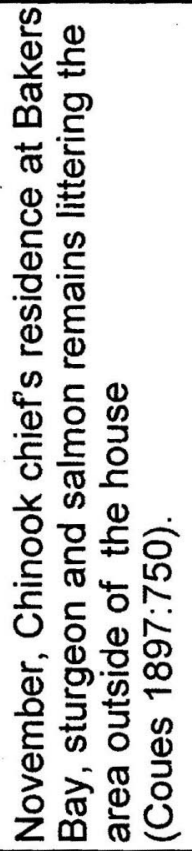 & 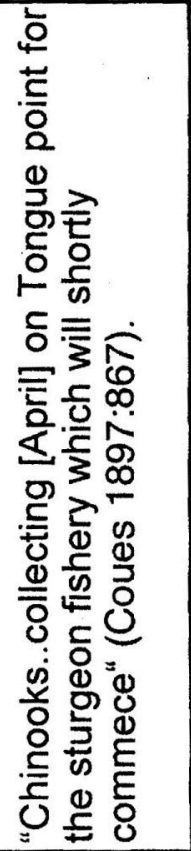 & 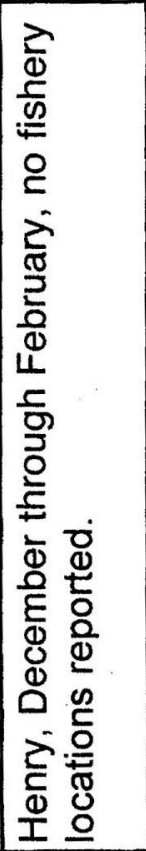 & 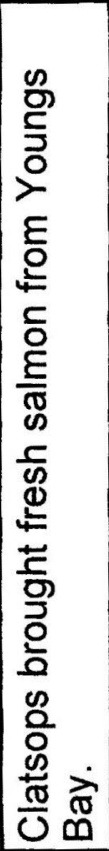 \\
\hline & $\frac{5}{i \frac{1}{1}}$ & & & & 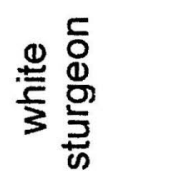 & & & $\begin{array}{l}\frac{\overline{0}}{0} \\
\frac{\mathbb{0}}{\bar{T}} \\
\frac{1}{1}\end{array}$ & 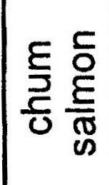 \\
\hline
\end{tabular}




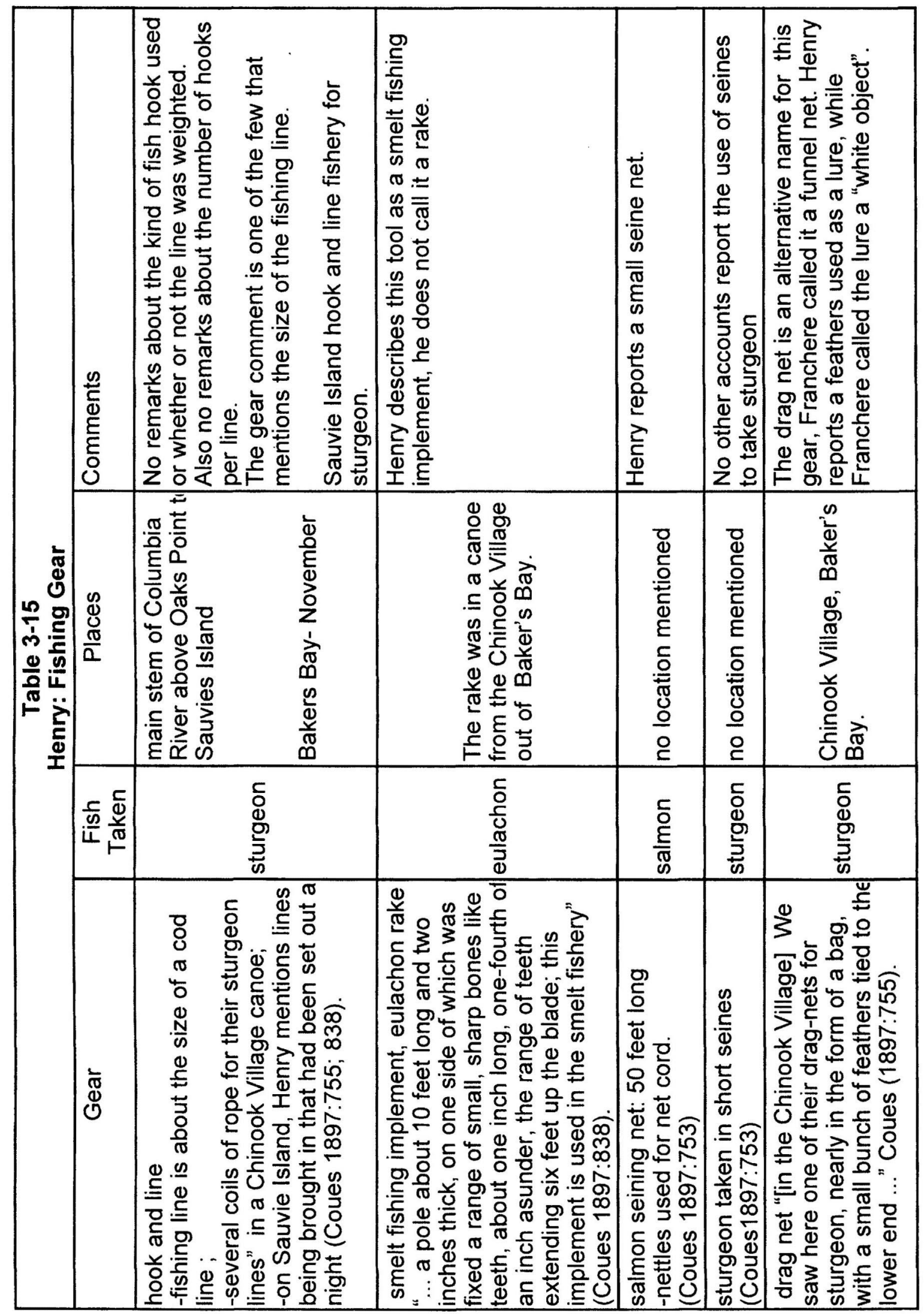




\begin{tabular}{|c|c|c|c|c|c|c|c|}
\hline \multirow{5}{*}{ 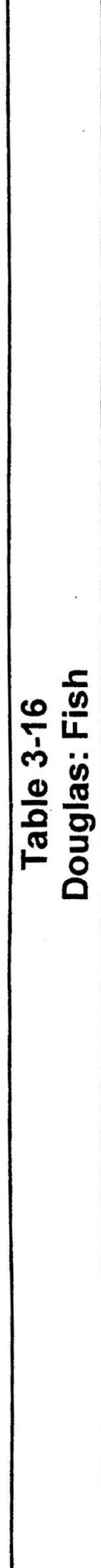 } & 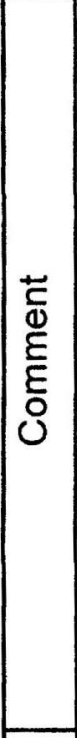 & 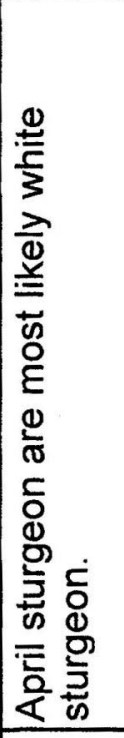 & 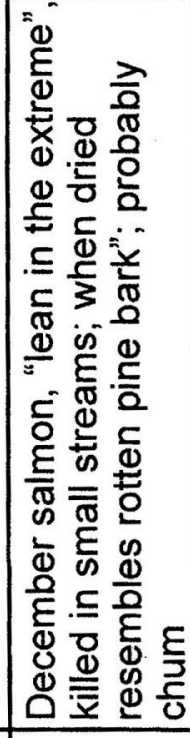 & 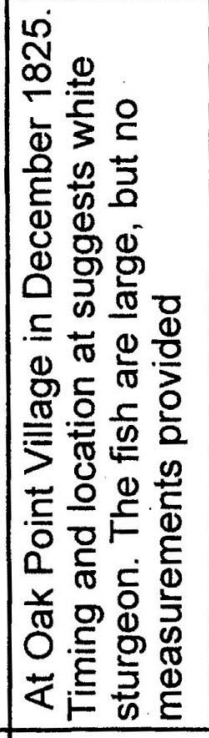 & 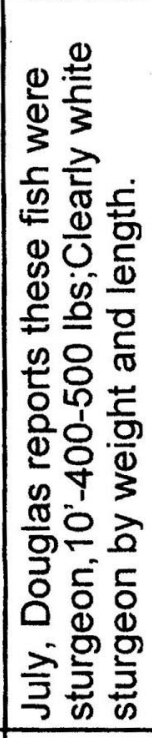 & 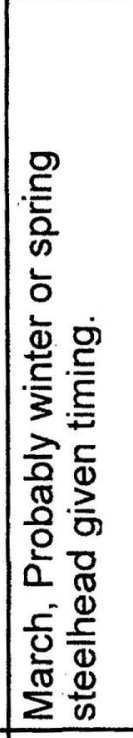 & 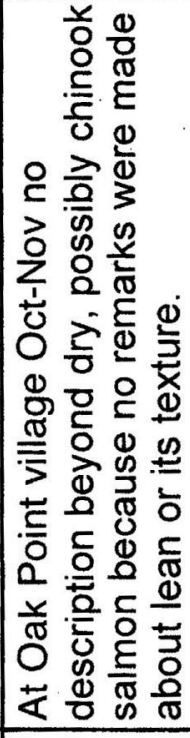 \\
\hline & 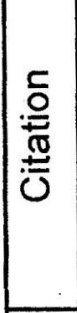 & 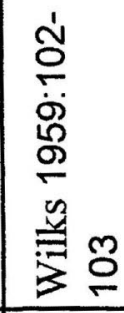 & 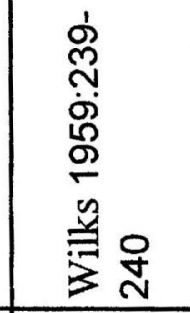 & 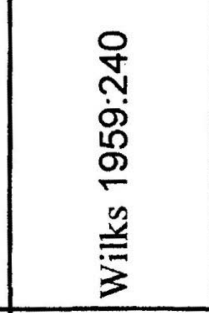 & 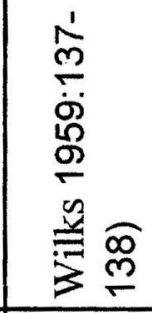 & 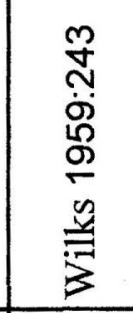 & 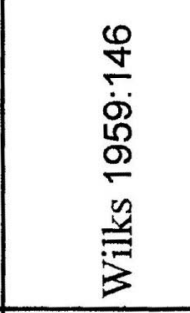 \\
\hline & \begin{tabular}{|l}
$\infty$ \\
$\frac{\omega}{0}$ \\
$\mathbb{0}$ \\
$\tilde{\omega}$ \\
$\infty$
\end{tabular} & ष & $\begin{array}{l}\frac{\pi}{0} \\
\frac{0}{0}\end{array}$ & 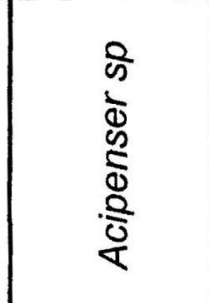 & 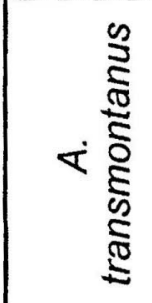 & 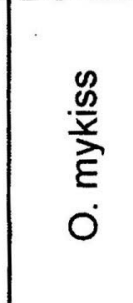 & $\begin{array}{l}\frac{\pi}{0} \\
\frac{D}{5} \\
\frac{5}{0} \\
\frac{0}{5} \\
0\end{array}$ \\
\hline & 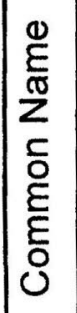 & 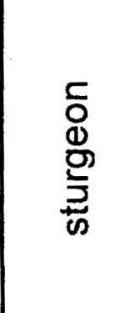 & 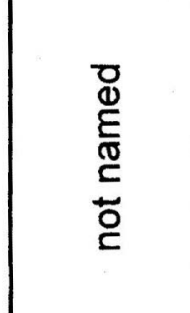 & 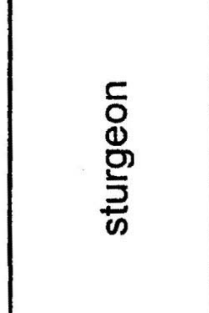 & 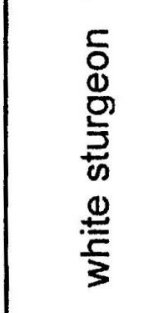 & 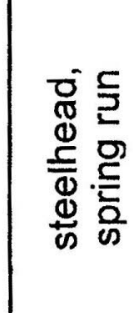 & 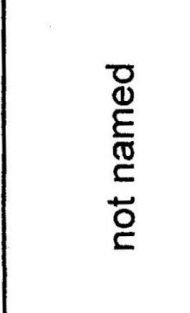 \\
\hline & 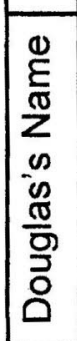 & 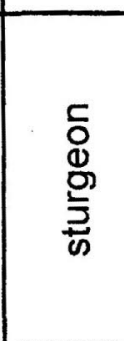 & 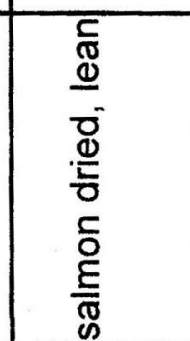 & 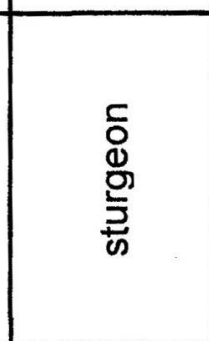 & 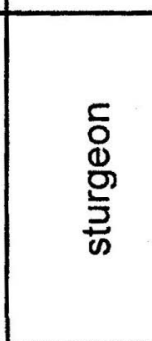 & 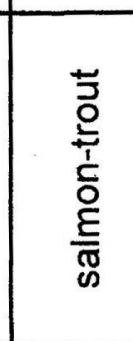 & 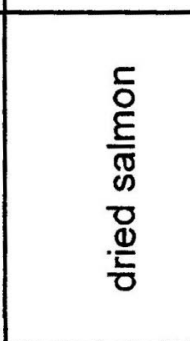 \\
\hline
\end{tabular}




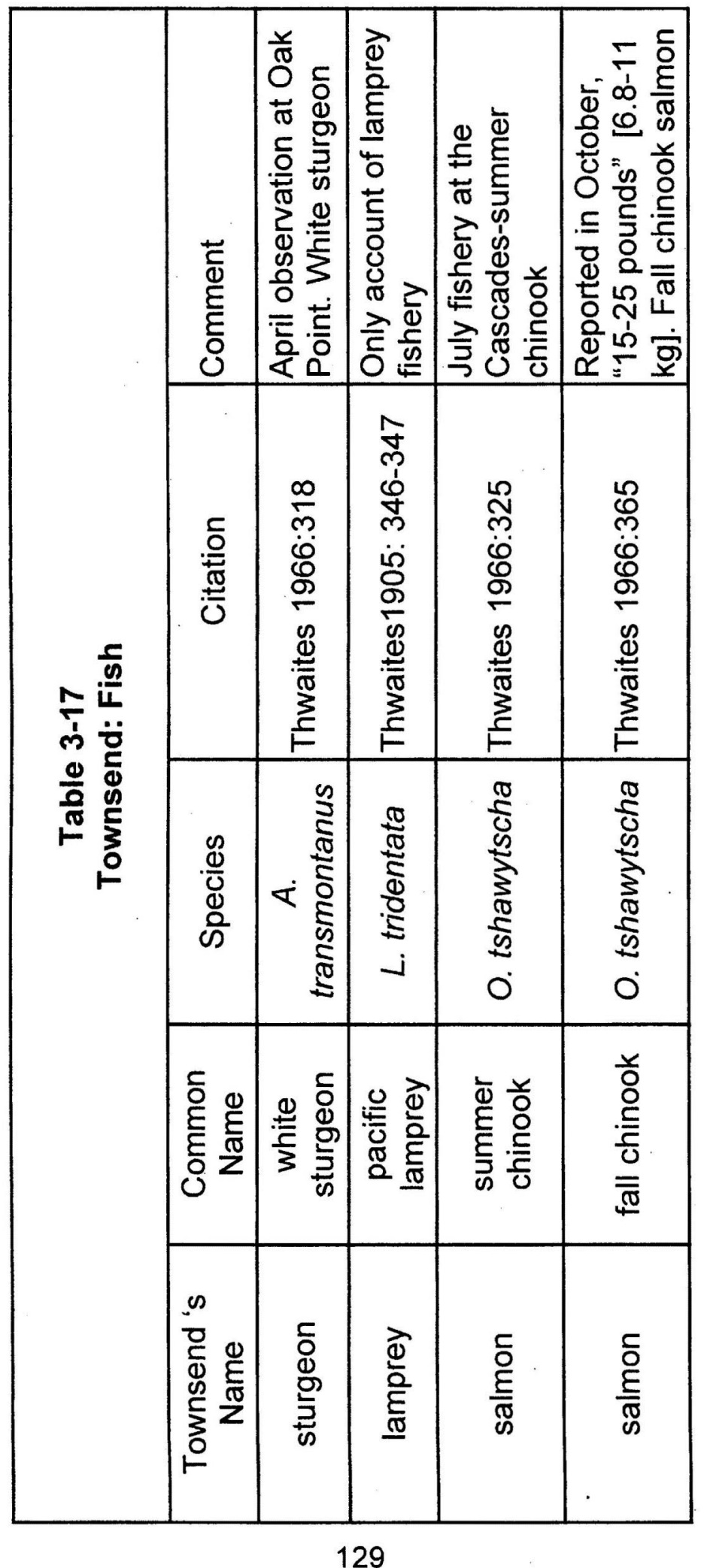




\begin{tabular}{|c|c|c|c|c|}
\hline & 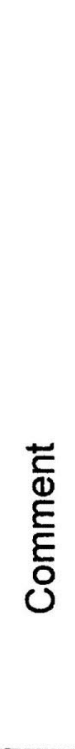 & 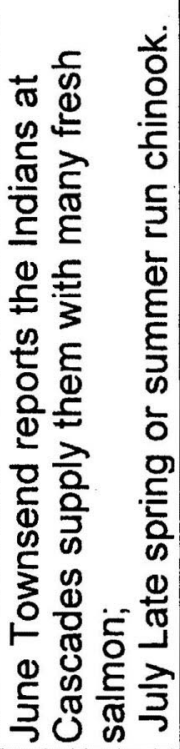 & 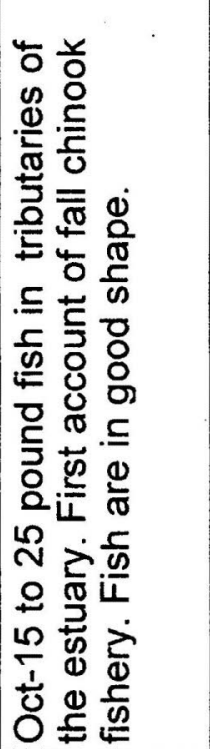 & 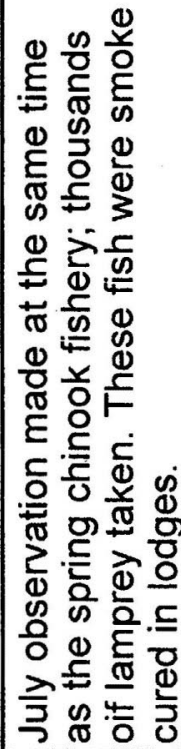 \\
\hline & 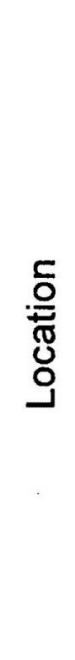 & 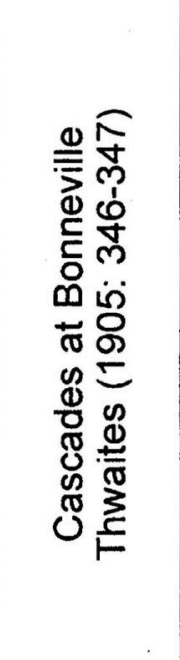 & 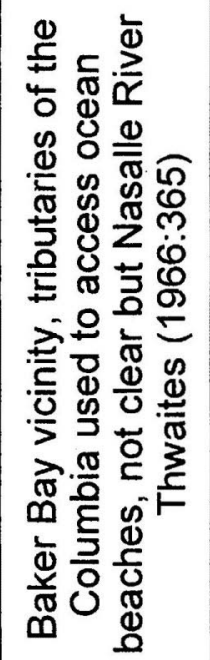 & 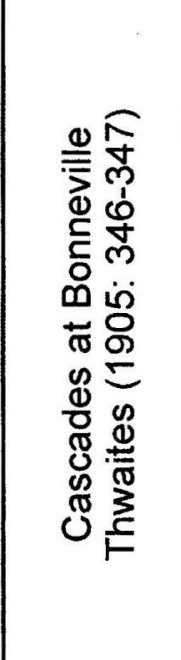 \\
\hline & $\frac{\frac{\lambda}{\Phi}}{\frac{D}{\mathscr{D}}}$ & 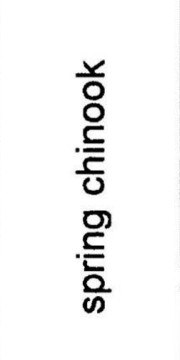 & 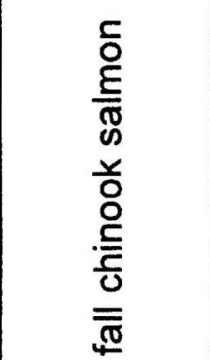 & $\begin{array}{l}\frac{\widehat{\varpi}}{0} \\
\text { है } \\
\underline{\widetilde{\sigma}}\end{array}$ \\
\hline
\end{tabular}




\begin{tabular}{|c|c|c|c|c|c|}
\hline \multirow{4}{*}{ 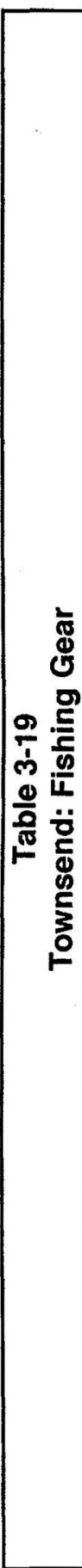 } & 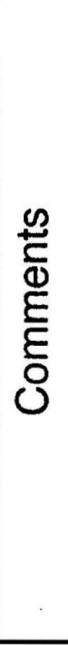 & \multicolumn{3}{|c|}{ 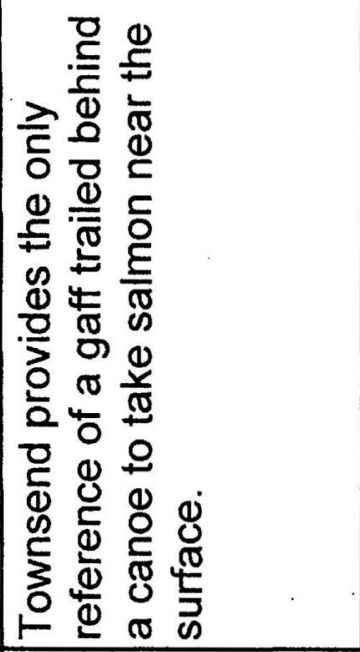 } & 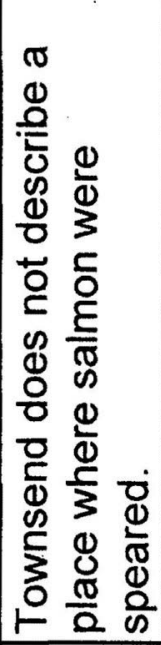 \\
\hline & 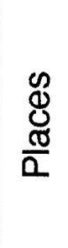 & \multicolumn{3}{|c|}{ 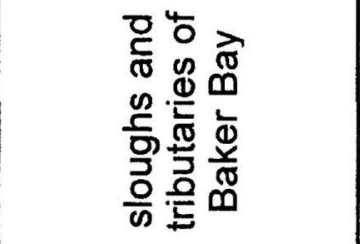 } & 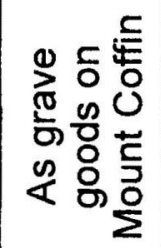 \\
\hline & 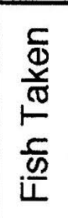 & \multicolumn{3}{|c|}{ 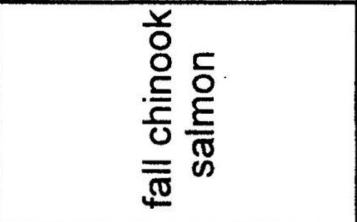 } & 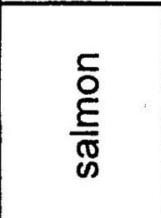 \\
\hline & 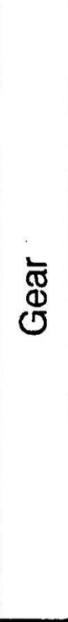 & 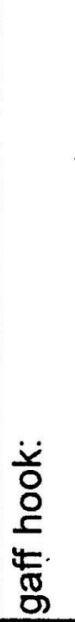 & 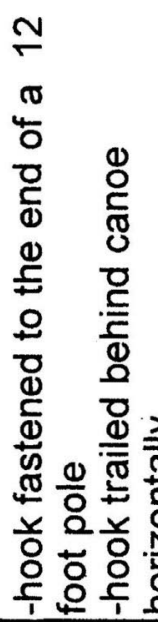 & 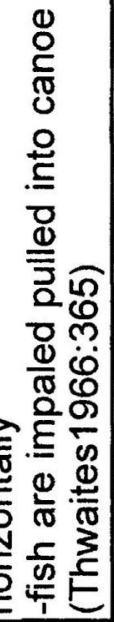 & 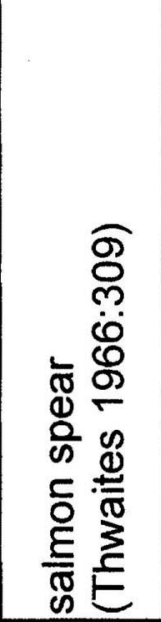 \\
\hline
\end{tabular}




\begin{tabular}{|c|c|c|c|c|c|c|c|}
\hline \multirow{5}{*}{ 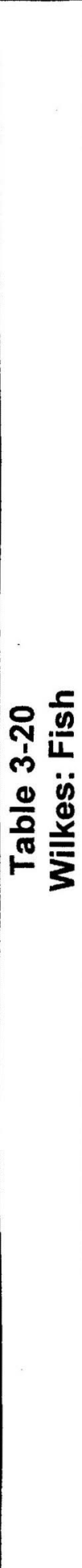 } & 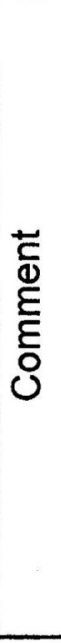 & 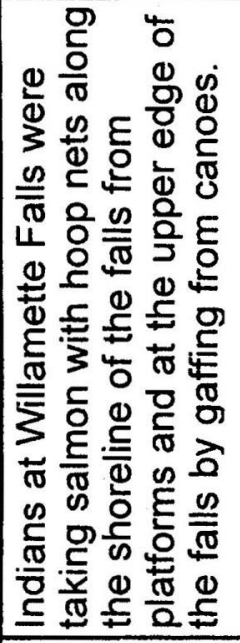 & 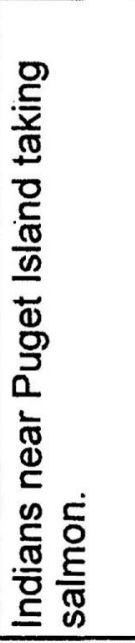 & 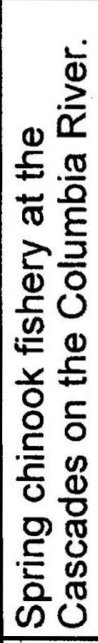 & 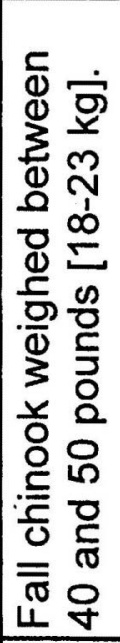 & 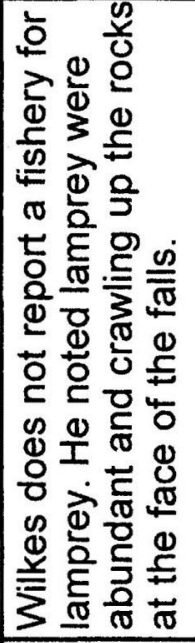 & 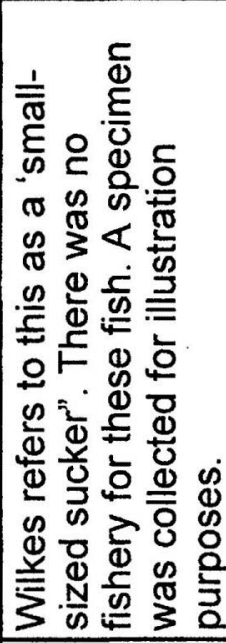 \\
\hline & 喜 & 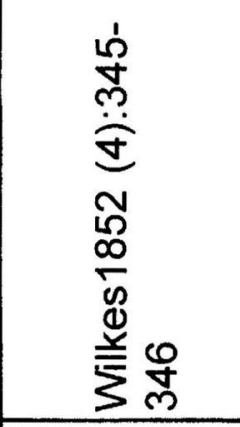 & 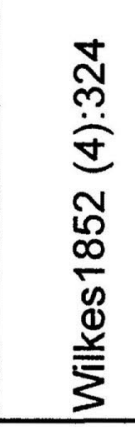 & 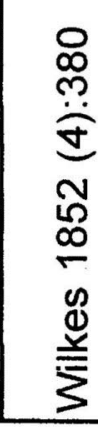 & 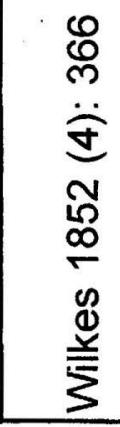 & 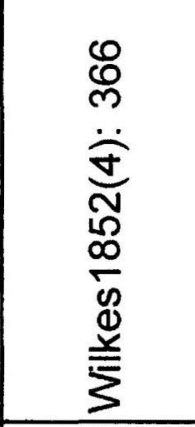 & 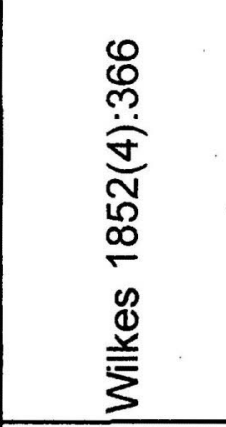 \\
\hline & $\begin{array}{l}\mathscr{0} \\
\frac{\mathscr{D}}{\Phi} \\
\frac{0}{10}\end{array}$ & & 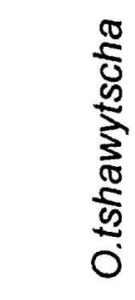 & & & 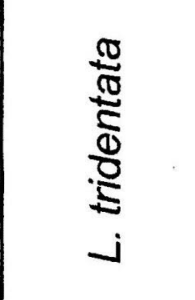 & 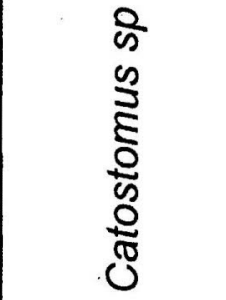 \\
\hline & 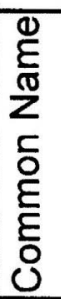 & & §్ & & & 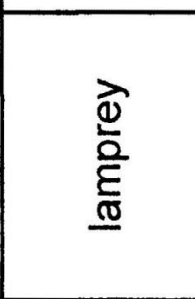 & $\frac{\grave{d}}{\frac{d}{0}}$ \\
\hline & 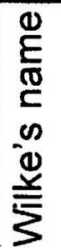 & 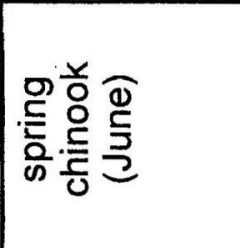 & & & 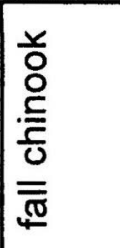 & 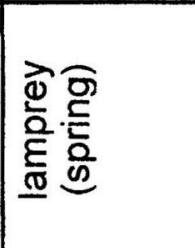 & 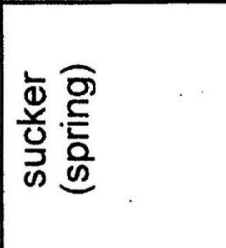 \\
\hline
\end{tabular}




\begin{tabular}{|c|c|c|c|c|c|c|}
\hline \multirow[t]{3}{*}{ 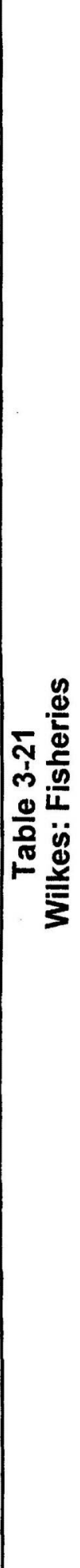 } & 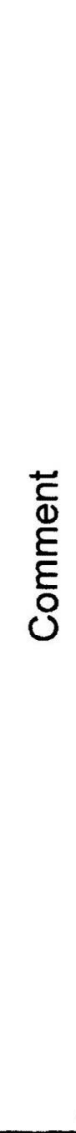 & 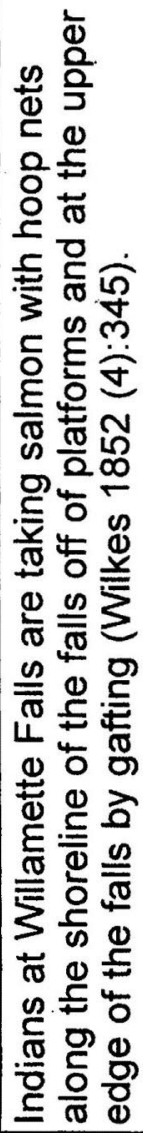 & 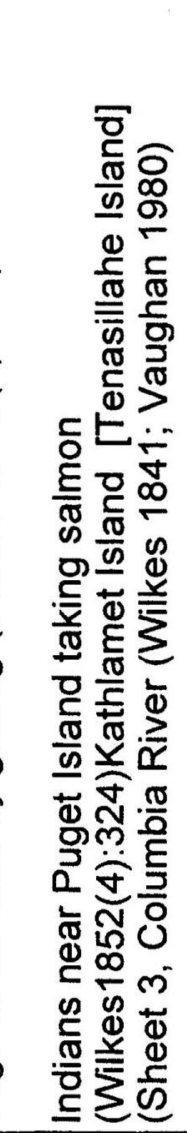 & 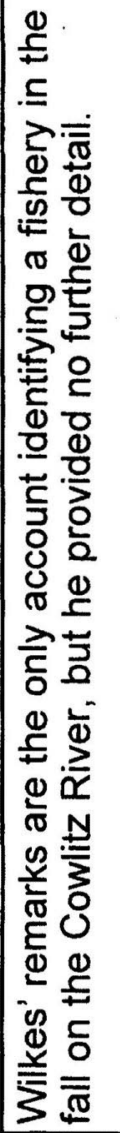 & 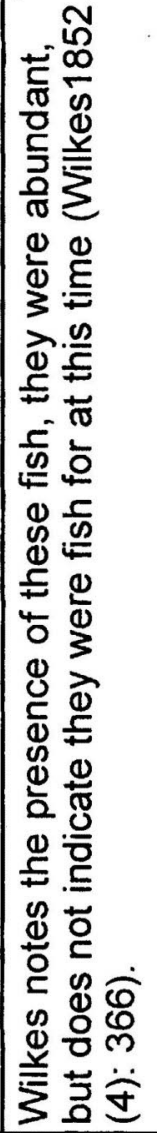 & 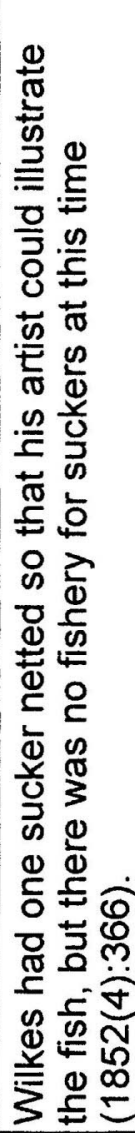 \\
\hline & $\begin{array}{l}0 \\
\mathbb{\pi} \\
\square\end{array}$ & 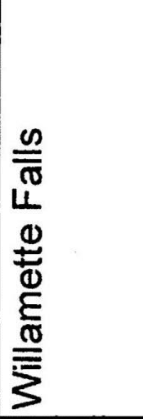 & 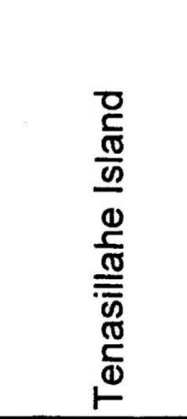 & 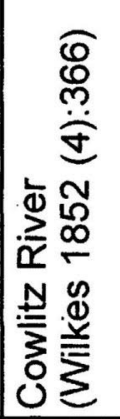 & 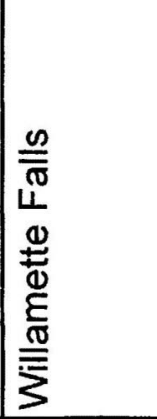 & 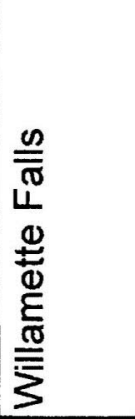 \\
\hline & 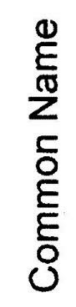 & & 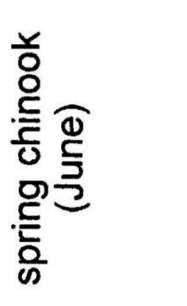 & $\begin{array}{l}\frac{0}{c} \\
\frac{0}{0} \\
\bar{\pi}\end{array}$ & 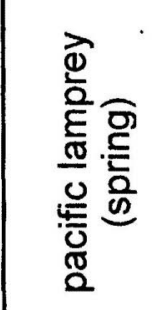 & 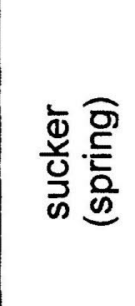 \\
\hline
\end{tabular}




\begin{tabular}{|c|c|c|c|c|c|}
\hline \multirow{4}{*}{ 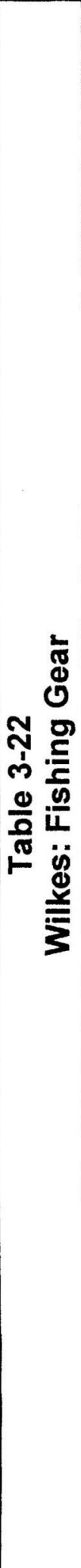 } & 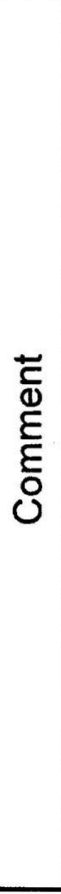 & 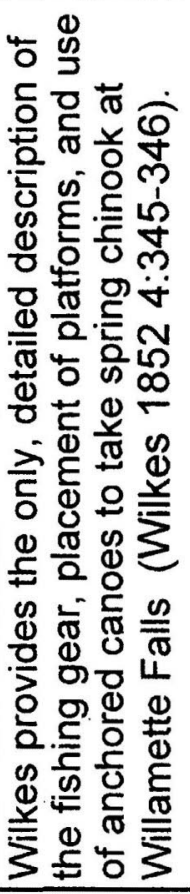 & 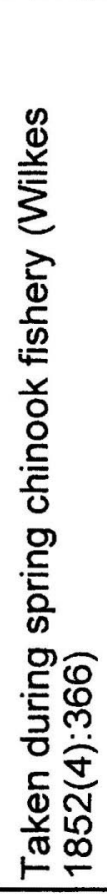 & 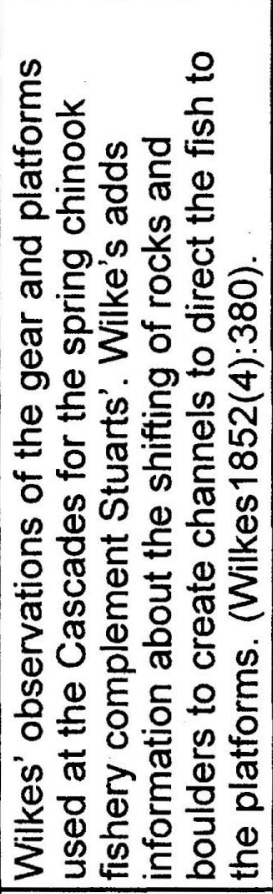 & 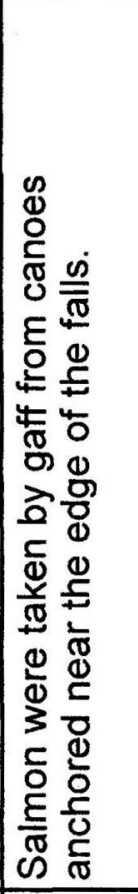 \\
\hline & $\begin{array}{l}\mathscr{D} \\
\text { U్ } \\
\frac{\mathbb{\pi}}{\alpha}\end{array}$ & 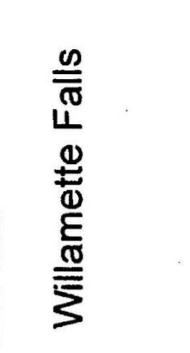 & 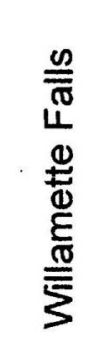 & 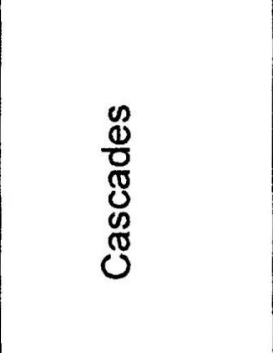 & 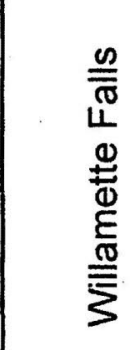 \\
\hline & 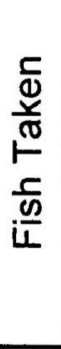 & 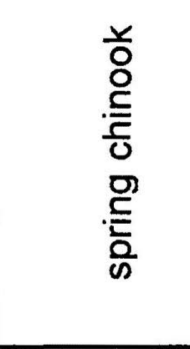 & 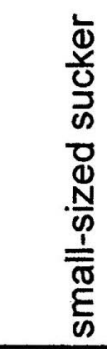 & 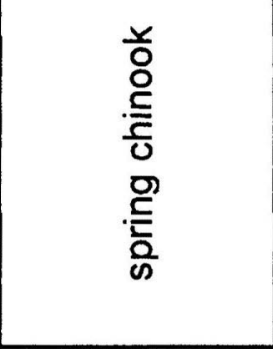 & 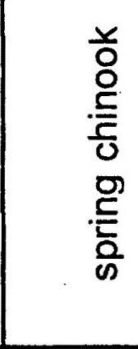 \\
\hline & $\begin{array}{l}\bar{\varpi} \\
\mathbb{\varpi} \\
0\end{array}$ & & 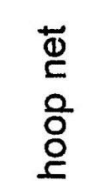 & & 产 \\
\hline
\end{tabular}




\begin{tabular}{|c|c|c|c|c|c|c|c|c|c|}
\hline \multirow{5}{*}{ 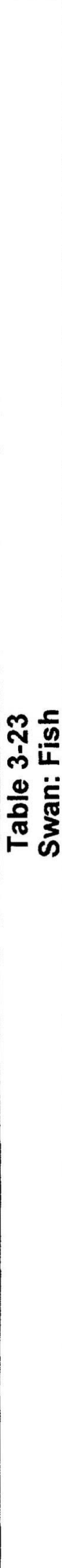 } & 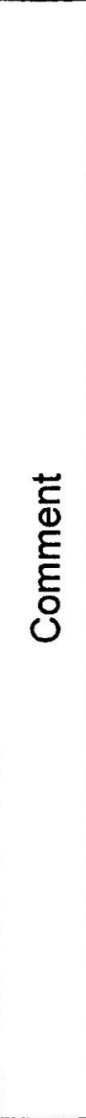 & 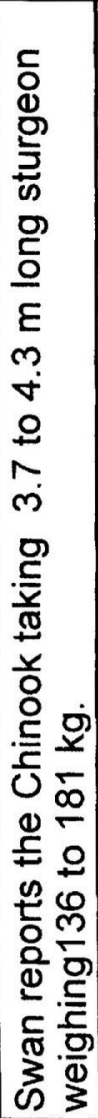 & 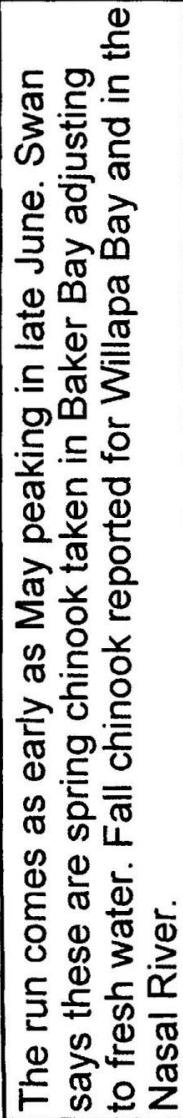 & 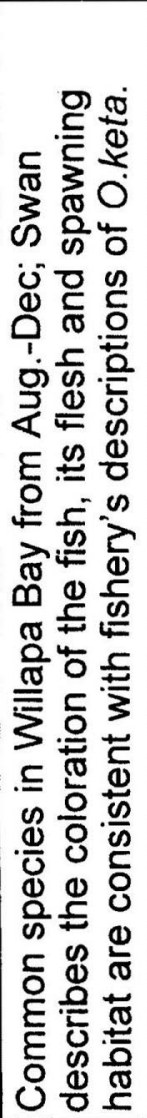 & 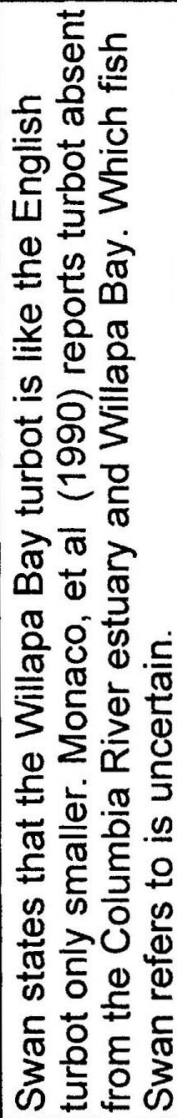 & 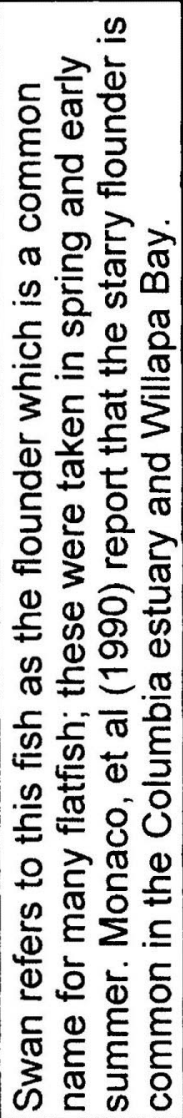 & 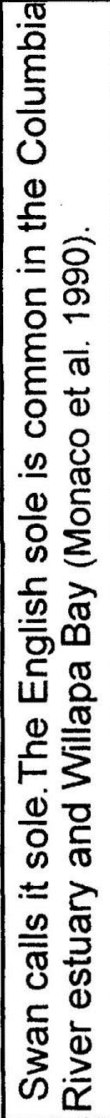 & 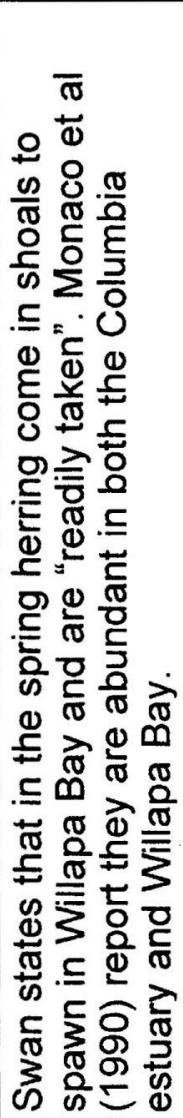 & 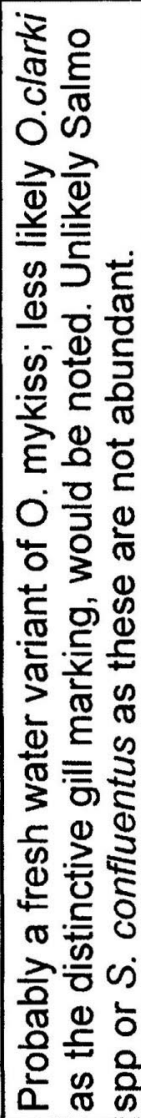 \\
\hline & 突 & 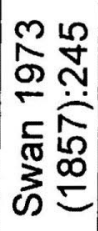 & 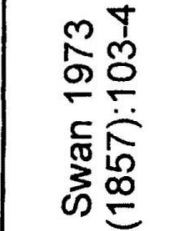 & 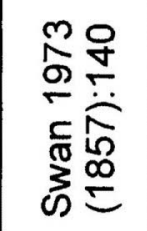 & 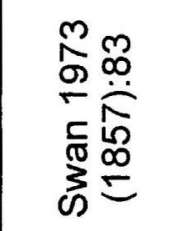 & 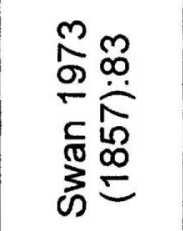 & 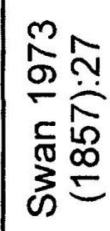 & 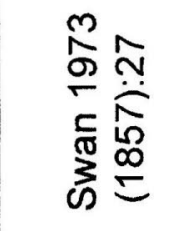 & 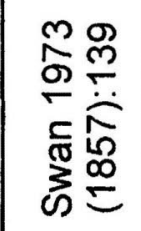 \\
\hline & $\begin{array}{l}\mathscr{D} \\
\frac{\mathbb{U}}{0} \\
\mathbb{d} \\
\stackrel{0}{0}\end{array}$ & 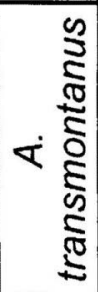 & $\begin{array}{l}\frac{0}{0} \\
\frac{5}{D} \\
\frac{7}{0} \\
\frac{D}{D} \\
\frac{D}{2} \\
0\end{array}$ & $\frac{\pi}{\frac{\pi}{0}}$ & $\begin{array}{l}\frac{5}{\sqrt{5}} \\
\frac{t}{d} \\
\frac{0}{5} \\
\frac{5}{5}\end{array}$ & $\begin{array}{l}\frac{C}{\mathbb{D}} \\
\frac{t}{d} \\
\frac{U}{J} \\
\frac{C}{J}\end{array}$ & 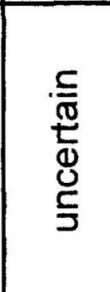 & $\begin{array}{l}\bar{w} \\
\frac{\pi}{\pi} \\
0 \\
0\end{array}$ & 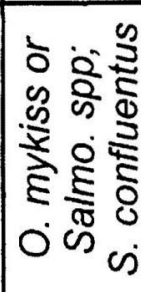 \\
\hline & 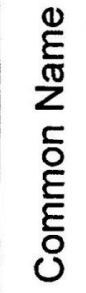 & 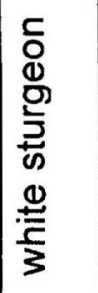 & $\begin{array}{l}\text { 음 } \\
\frac{O}{\frac{O}{C}} \\
\frac{1}{0}\end{array}$ & $\frac{E}{\grave{\partial}}$ & $\frac{\omega n}{\frac{\omega n}{6}}$ & $\underset{\frac{\pi}{\omega}}{\frac{\pi}{4}}$ & $\begin{array}{l}\frac{0}{0} \\
0 \\
\frac{c}{0} \\
\frac{D}{0} \\
\frac{c}{1}\end{array}$ & 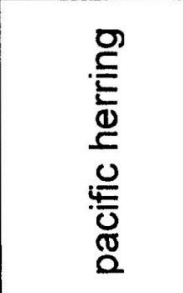 & 온 \\
\hline & 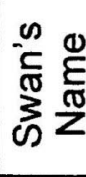 & 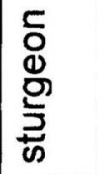 & 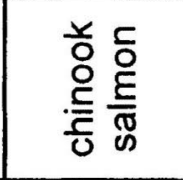 & 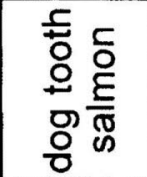 & 는 & $\begin{array}{l}\frac{\bar{d}}{0} \\
\frac{5}{5} \\
\text { 은 }\end{array}$ & চঁচ & 亮 & 은 \\
\hline
\end{tabular}




\begin{tabular}{|c|c|c|c|c|c|c|c|c|c|}
\hline \multirow[t]{3}{*}{ 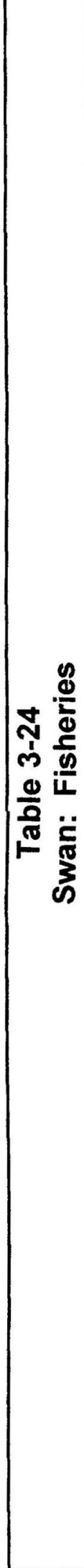 } & $\begin{array}{c}\bar{c} \\
\bar{\Phi} \\
E \\
E \\
\mathcal{E} \\
\mathcal{U}\end{array}$ & 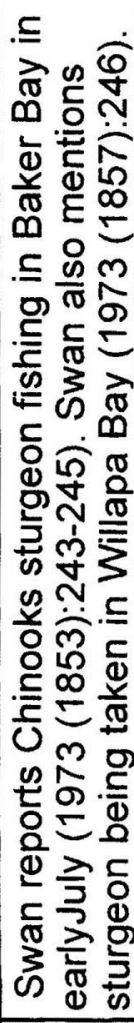 & 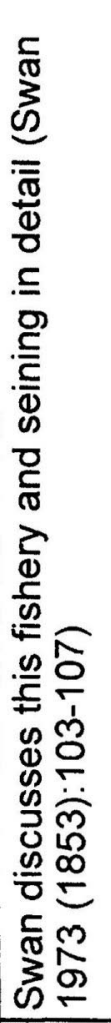 & 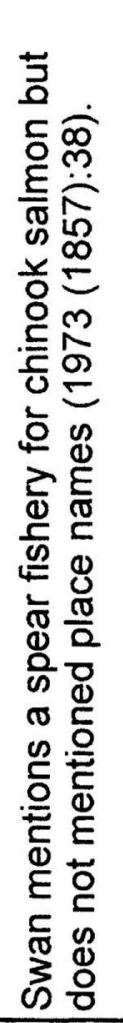 & 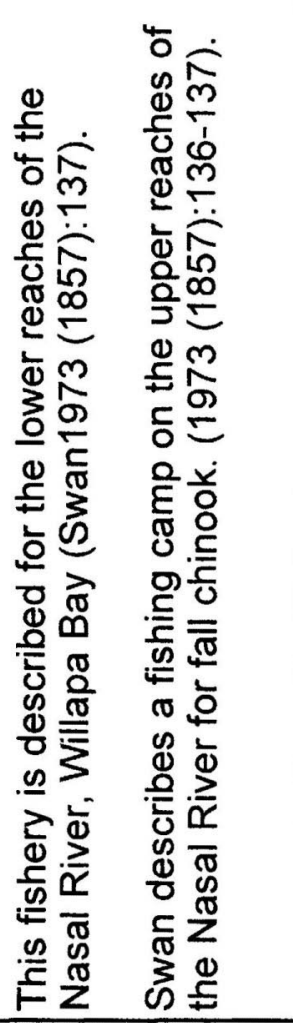 & 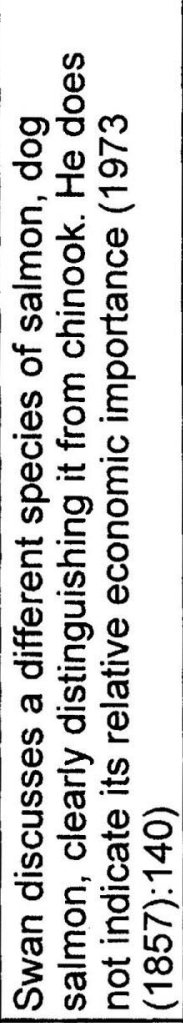 & 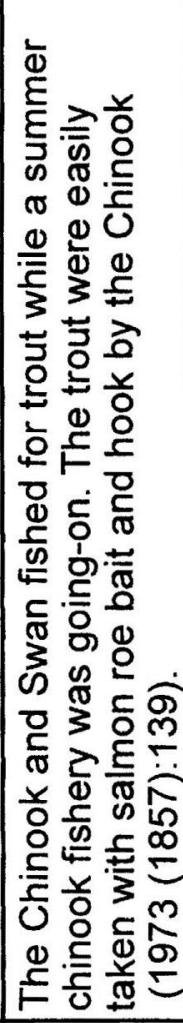 & 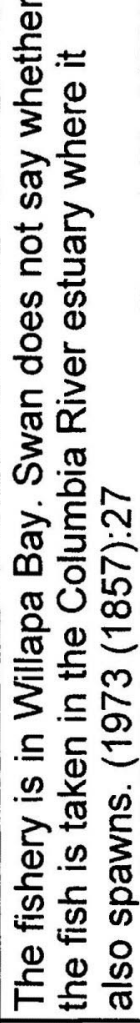 & 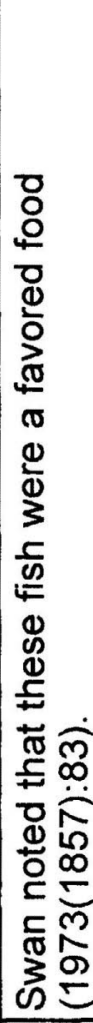 \\
\hline & $\begin{array}{l}\mathbb{U} \\
\frac{\mathbb{O}}{2} \\
\end{array}$ & 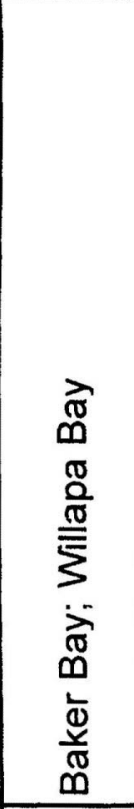 & 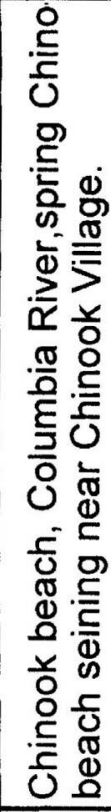 & 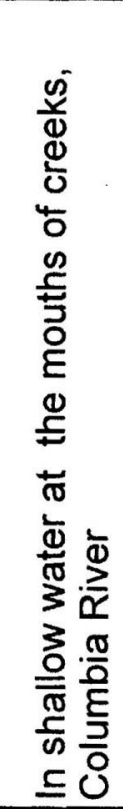 & 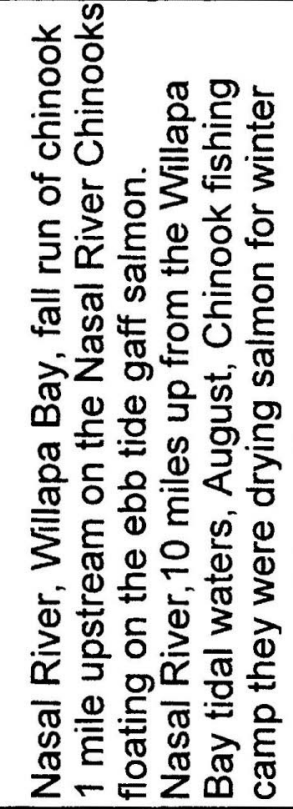 & 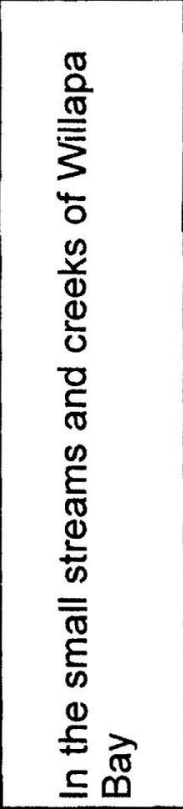 & 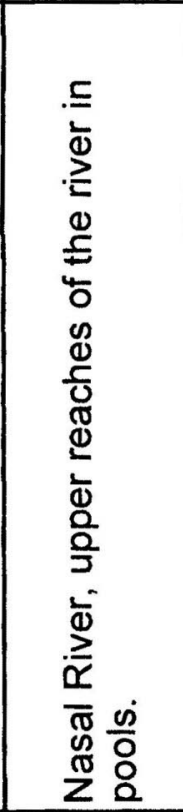 & 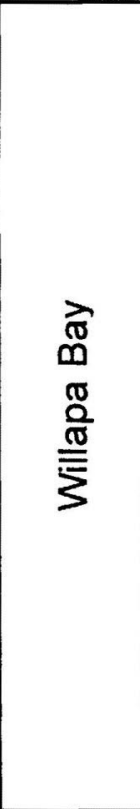 & 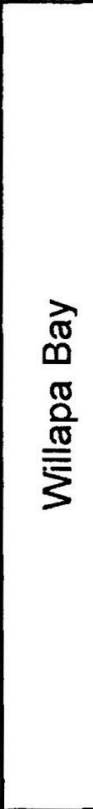 \\
\hline & $\frac{\frac{\lambda}{\alpha}}{\frac{\bar{\omega}}{\underline{D}}}$ & 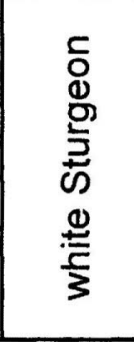 & & & 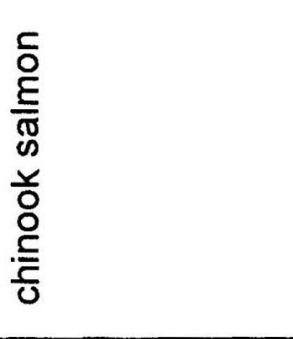 & ত & 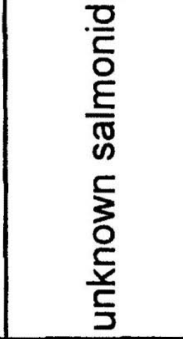 & 脑 & 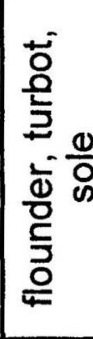 \\
\hline
\end{tabular}




\begin{tabular}{|c|c|c|c|c|c|c|c|c|c|c|}
\hline & 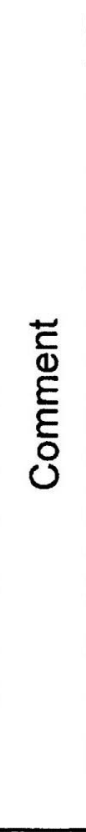 & 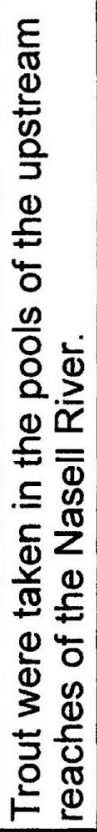 & 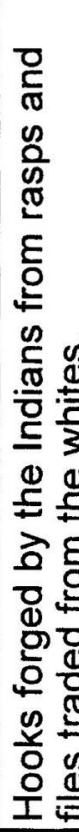 & 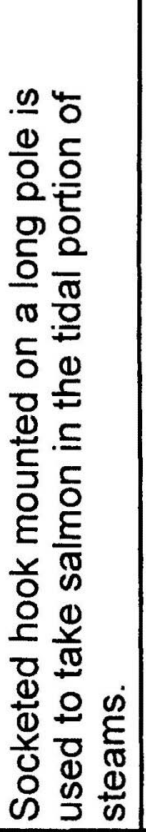 & 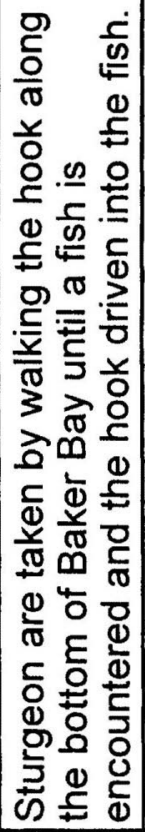 & 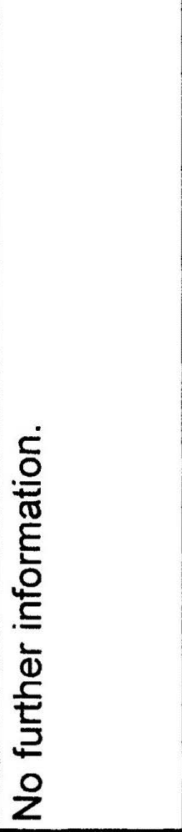 & 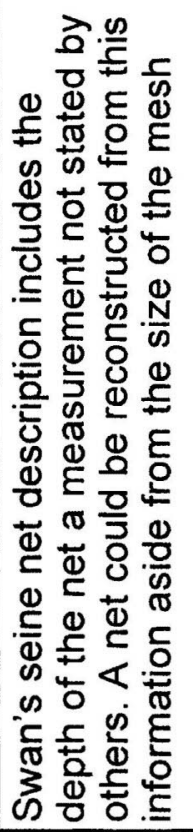 & 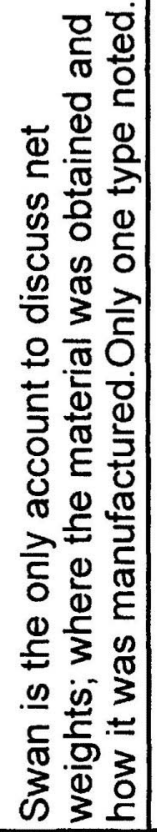 & 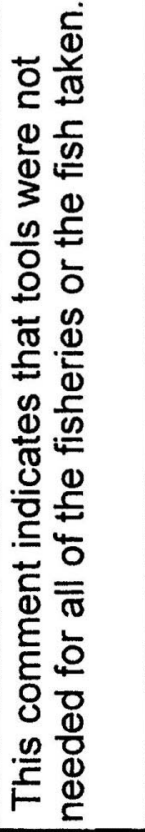 & 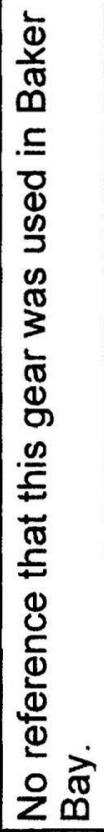 \\
\hline & 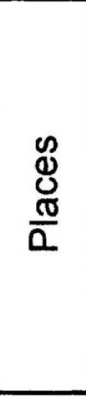 & 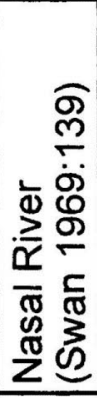 & 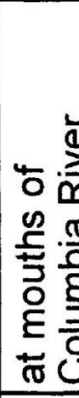 & 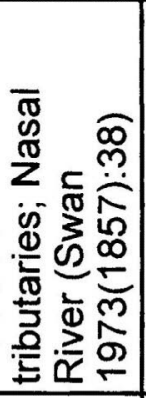 & 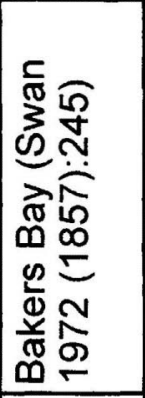 & 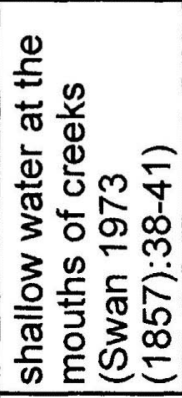 & 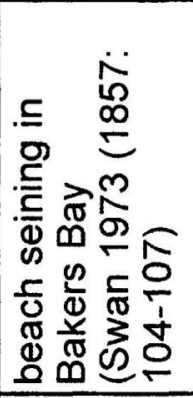 & & 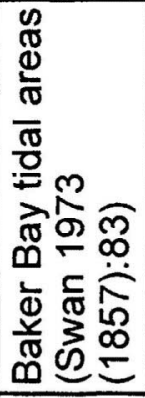 & 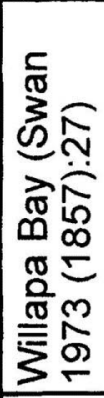 \\
\hline & 递市 & 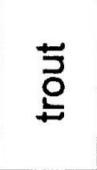 & $\frac{\text { 을 }}{\text { है }}$ & & 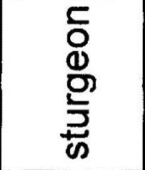 & $\frac{\text { ᄃ }}{\stackrel{\text { है }}{\overparen{D}}}$ & & & $\begin{array}{l}\frac{1}{0} \\
\frac{0}{2} \\
\frac{0}{5} \\
\frac{0}{4}\end{array}$ & 옳 \\
\hline & $\begin{array}{l}\bar{\Phi} \\
\mathbb{0}\end{array}$ & 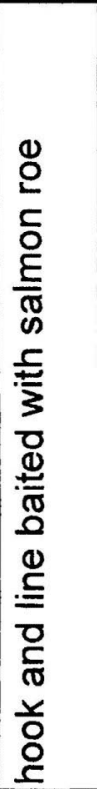 & 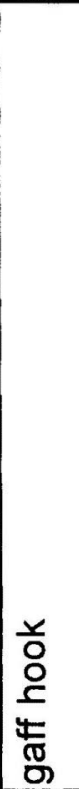 & 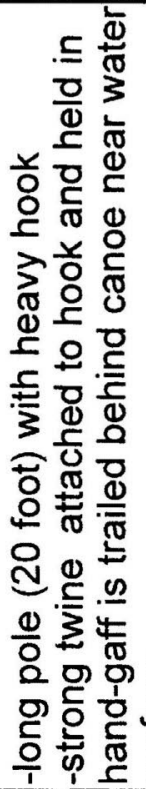 & 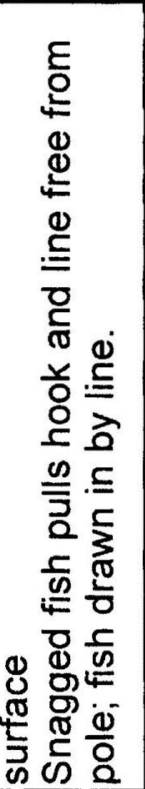 & 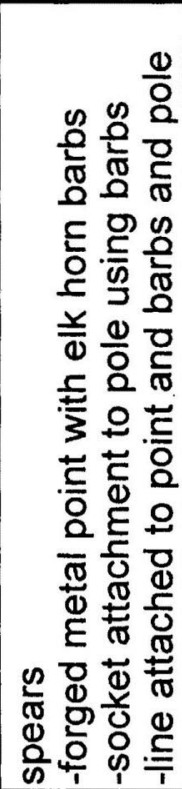 & 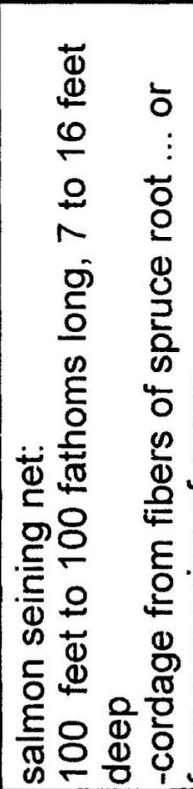 & 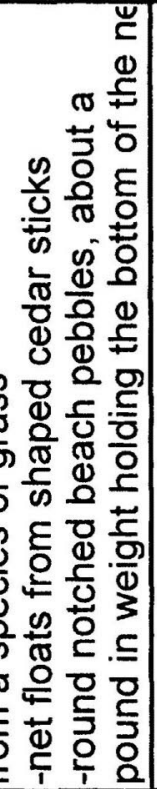 & 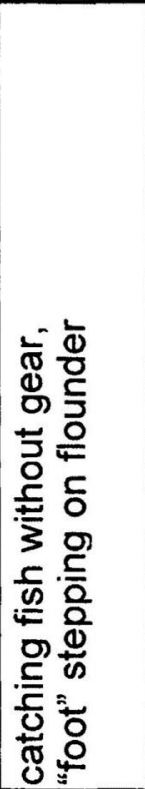 & 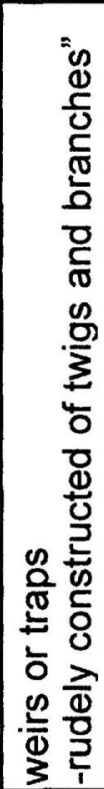 \\
\hline
\end{tabular}



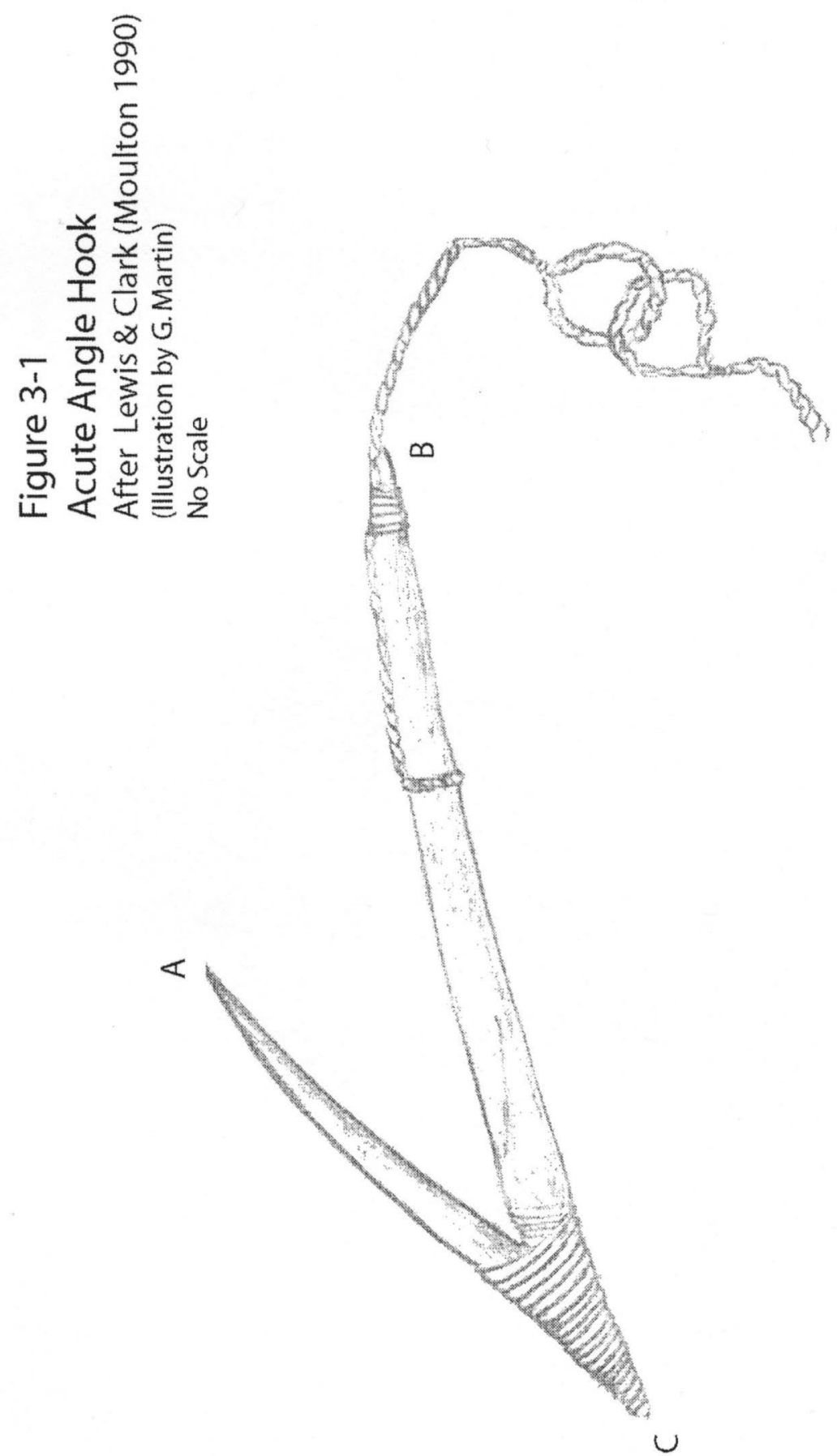


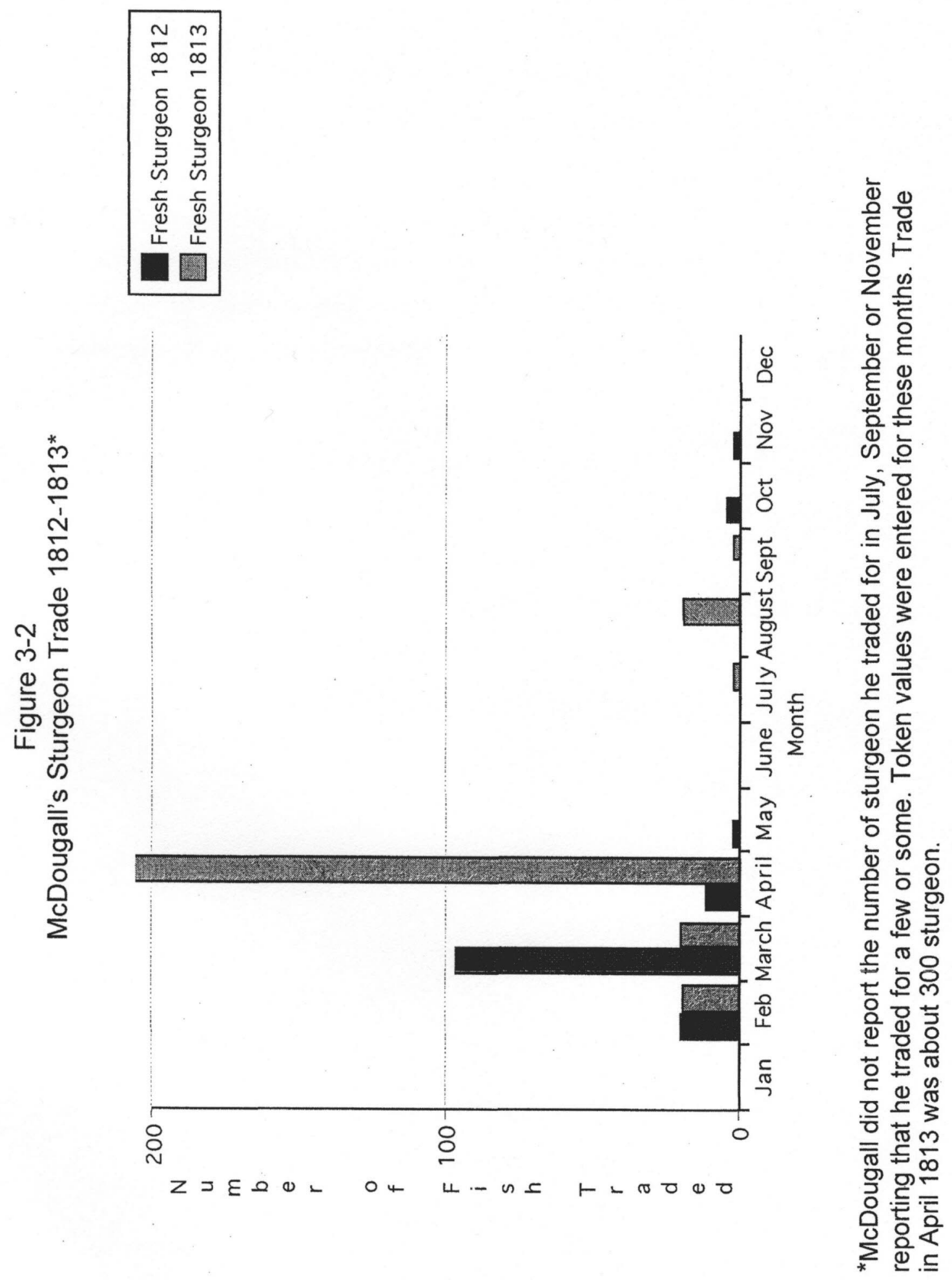




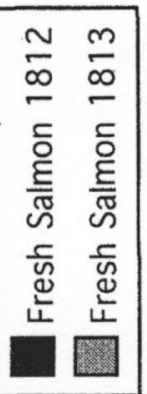

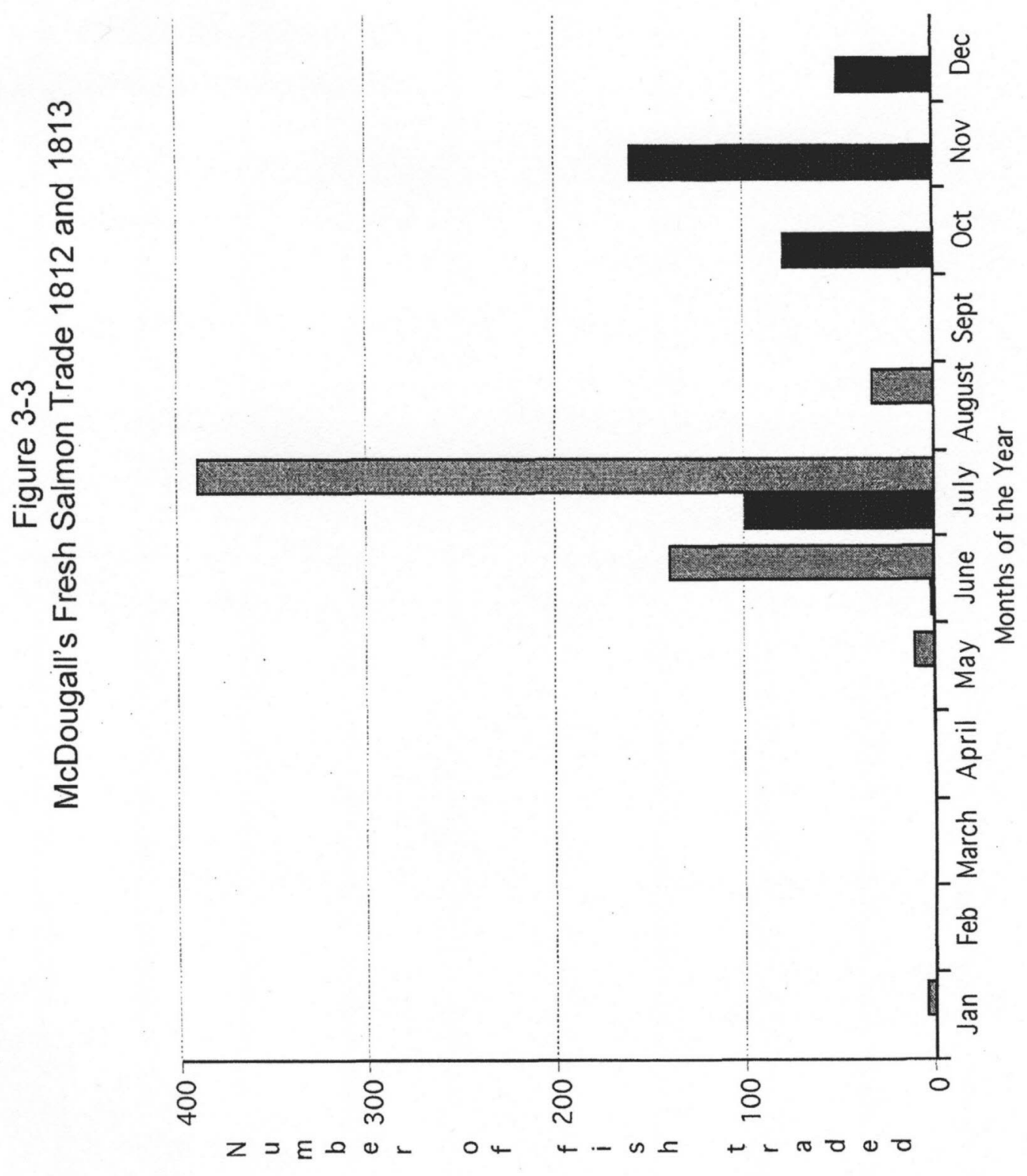




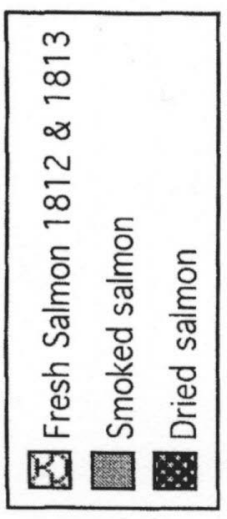

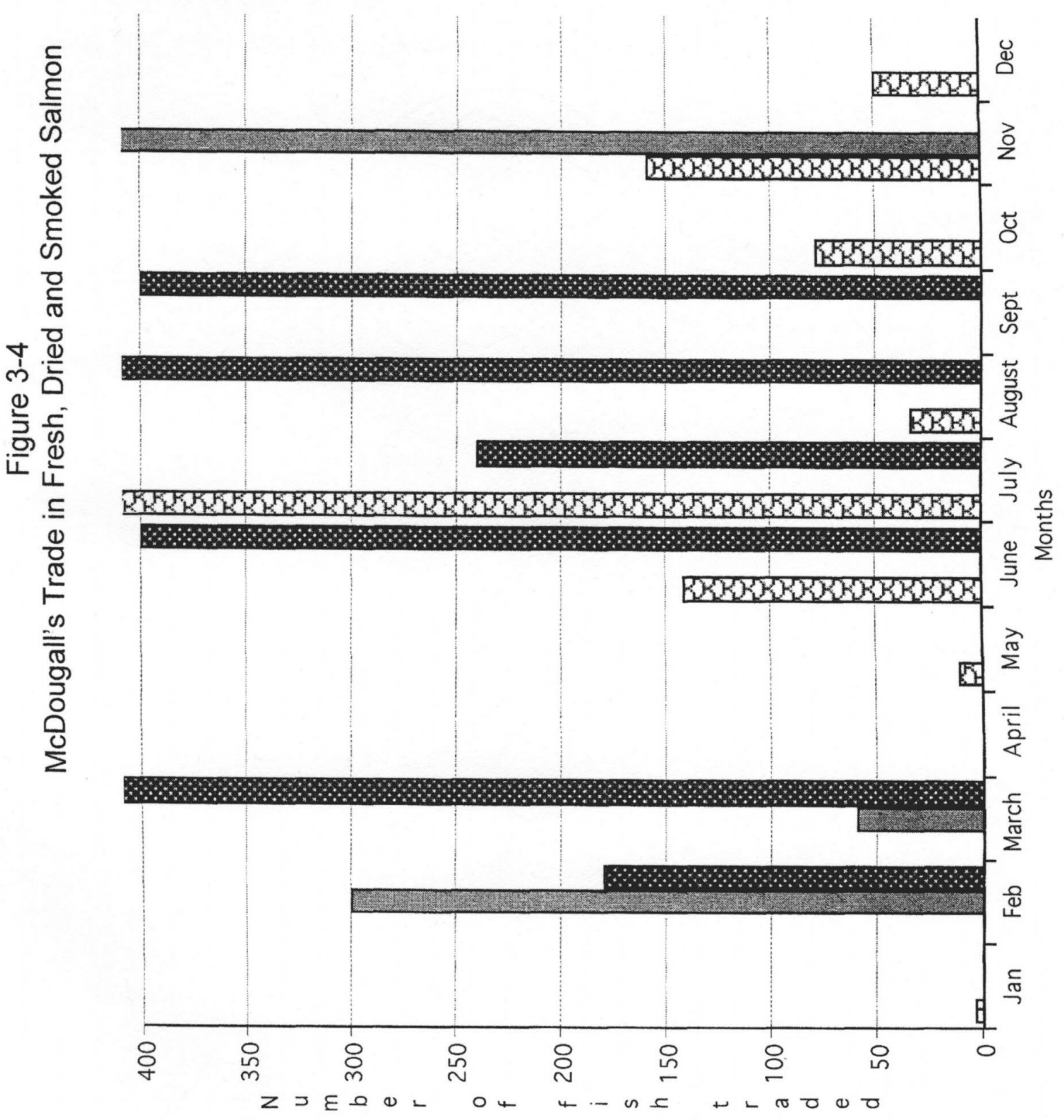




$$
E
$$



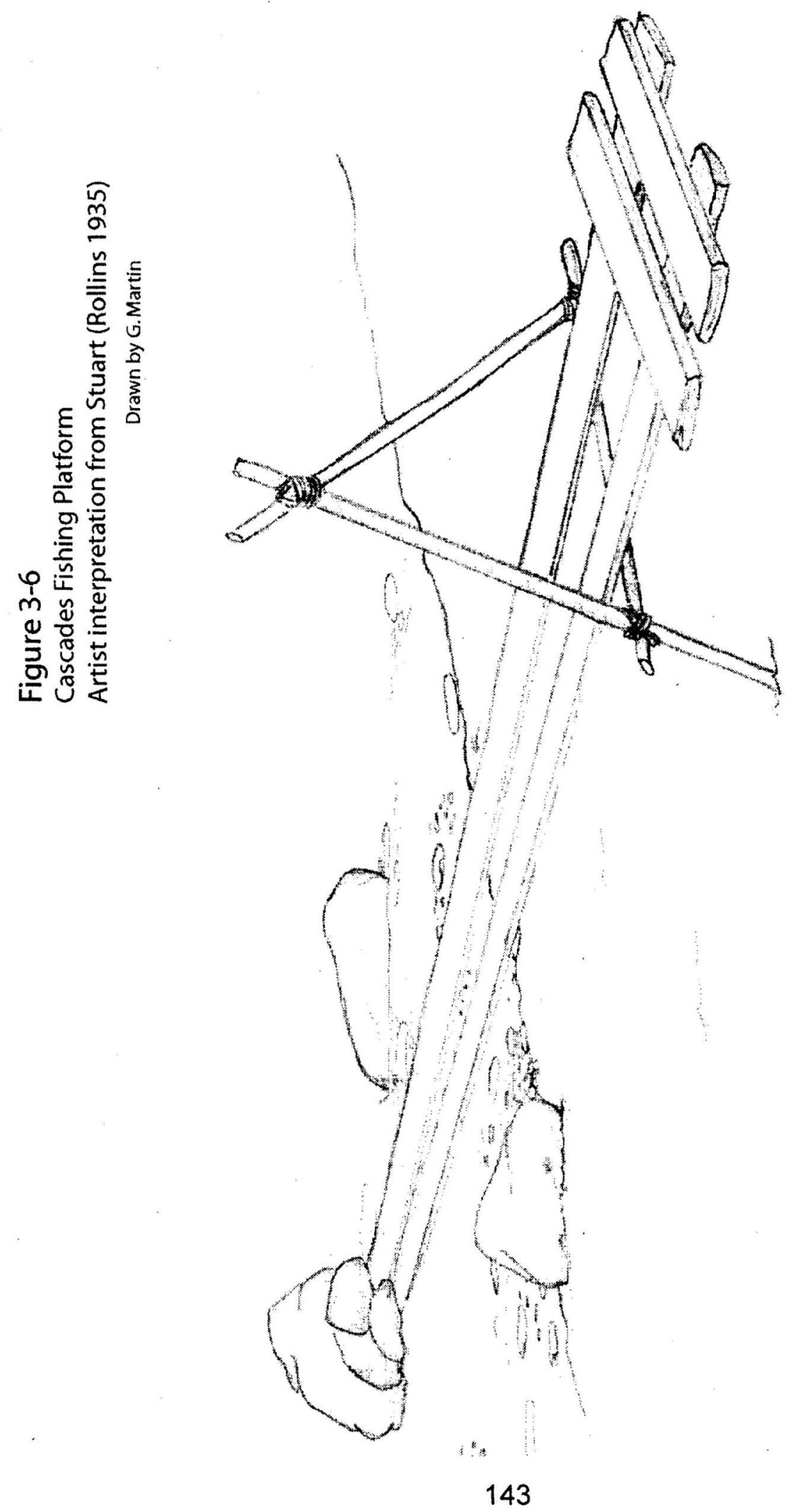


\section{CHAPTER 4}

\section{FISH TRADE AND THE FISHERIES}

In the Introduction I raised these questions: What fish besides salmon were chosen as resources? How were the various species of salmon used? Given the fish used as resources: Where were they taken? What gear was used to take them? When were the various fisheries initiated? Is there evidence of specialized gear used to take particular fish? How productive were the fisheries? I partially addressed these questions in Chapter 3 by annotating and organizing information on fish, gear, location, production and use, account by account.

In this synthesis I look at the broader picture of fish use over the period of study using the different accounts, first to define the minor and major fisheries and then to consider how they provided a regular flow of fish into the economy. As part of this discussion I note instances where different species of fish were taken at the same time and what underlying reasons may account for this opportunity.

I consider whether some gear was specifically designed to take particular fish at certain times of the year. I also discuss gear that had a more general application perhaps used in specific environmental settings. In this case I note the modifications that allowed the extension of certain kinds of gear throughout the range of particular prey.

There are also significant gaps in the accounts I cite which are important to recognize as they limit what can be discussed. For example, how important was seining during the period of record or exactly what streams 
were fished for fall chinook or why was lamprey not part of the trade.

One possible reason for gaps in the record is the length of time and period of presence of the writers of the accounts. Lewis and Clark (Moulton $1990,1991)$ wintered in the study area leaving in the spring. Their account is unique, because they were the first explorers who were specifically required to assess the living conditions of the Indians.

McDougall (Jones 1999), Franchere (Franchere 1967) and Stuart (Rollins 1995) of the Pacific Fur Company were present at the beginning of the Pacific Fur Company's operation in the late spring of 1811 , but stayed for different lengths of time. McDougall directed the company's operations from 1811 through its sale to the Northwest Fur Company in 1813. Franchere was present from 1811 through 1814, working first for the Pacific Fur Company from 1811-1813 and then for the Northwest Fur Company until he left in 1814. Stuart, who provides many important details on the fisheries, was present for only one year. Henry (Gough 1992) was present from November 1813 through May 1814.

Douglas (Wilks 1959) a trained botanist, arrived at the Columbia River mouth in April 1825 spending 2 years in the Northwest region, mostly outside the study area. He left the northwest, returning in 1830 , but only spent a short period of time in the lower river. Townsend (Jackson 1978) was a naturalist with the Wyeth expedition spending $1833-1835$ in the study area, although he left in the winter of 1833 for the Hawaiian Islands. Wilkes spent a short time in the study area from May 1841-October 1841 as a leader of a scientific expedition.

Swan spent the early 1850's in the study area, but also lived with and in 
the vicinity of the Chinook Indians at the mouth of the Columbia River and at Willapa Bay.

There are also differences between accounts due to different goals, interests and relationships with Native Americans. Lewis and Clark's mission was to explore a route to the Pacific Coast, and document the people and how they made a living.

The early accounts, from 1811 to 1814 , are the administrative records of the Pacific and the Northwest Fur Companies and journals of their employees. These records are accounts of the fish trade which provided the food that supported the EuroAmerican crews of these companies. These accounts document the fish traded in large numbers, especially preserved fish, and included comments about where they were taken and the gear used to take them.

Though Douglas 1825-1827 (Wilks 1959: Davies1980) and Townsend 1833-35 (Thwaites 1966) provide useful information, their records are limited in detail. These accounts note interesting details of Indian life with a few remarks on fish mentioning distinctive physical attributes or which ones were desirable as food. Wilkes 1840 (1845) provided insight into the fishery at Willamette Falls, mentioned but did not discuss in detail in any other account. His information is consistent with Stuart (Rollins 1995) on the platform fishery for salmon at the Cascades.

Swan's record is distinctive. He was not making a living from the fur trade, he was not concerned about obtaining food and he had an interest in Indian culture for its own value. His record is an account of remarkable detail, but also of a people severely reduced in numbers, not the same people who 
Lewis and Clark (Moulton 1991), McDougall (Jones 1999) and Henry (Gough 1992) dealt with. Living with the Chinooks and sympathetic to their situation enabled Swan to write an important account, although the Chinooks by this time used a much smaller area to gather resources, and as far as Swan's record, did not move up and down the mainstem of the Columbia River as they did in the early 1800's.

All of these records reflect the tremendous changes that occurred to the Indian populations by introduced disease (Boyd 1999). Epidemics in the 1790 's devastated pre-contact populations. Epidemics in the 1830's had a tremendous impact on the native population, taking 80 to $90 \%$ of the people from Sauvie Island and other places. Thus, the subsistence pursuits reported in historic accounts after 1830's would probably be much different compared to those before this time.

The fisheries provided both fresh and preserved fish. Over the study period, many of the same fish are noted in the different accounts (Table 4-1). All the fish that were taken provided some fresh fish. However, a few species of fish were only traded in small numbers as fresh fish without any description of gear or location, or record of being preserved for storage.

\section{Minor Fish Resources}

The minor fish resources are those traded infrequently and in small numbers (Table 4-2). The presence of these fish suggests a potentially broader resource base.

\section{Surf Perch}

On April 12, 1814 Henry (Gough 1992:719) traded for a few fish he called silver bream taken near Cape Disappointment. No other account 
reports these fish and they were only traded to Henry once. There is no record of gear used to take these fish.

\section{Trout}

Resident trout were only reported twice in the historic records I cite. Henry traded for 8 trout on April 8, 1814 (Gough 1988-1992:714) and Swan (1973 (1857):139) reported two Indians fishing for trout using hook and line baited with salmon roe on the Nasal River during the fall chinook fishery in late-August.

\section{Salmon Trout}

White salmon trout. Salmon trout/white salmon, are likely steelhead, but this is difficult to confirm. During McDougall's trade for 26 small salmon trout on August 11, 1813 he also traded for 6 sturgeon. Sturgeon was the focus of specialist fishery in August. Those who were not fishing for sturgeon took fall chinook, and may have taken advantage of the presence of other fish, such as the small salmon trout (Jones 1999:209).

\section{Coho}

I have little information suggesting a coho fishery in the study area. Absence of coho in the economy of the study area is surprising as coho spawn in its tributaries and were once an important commercial fish (Fulton 1970:19). Their overall abundance and local available should have made them an important resource.

\section{Major Fish Resources}

Eulachon, sturgeon, lamprey, chum and chinook salmon were taken in large quantities and provided fresh and were the source of all of the preserved fish (Table 4-3). I note the timing and location of the fisheries. I consider 
information related to return rates of particular gear or quote qualitative statements that express the magnitude of the fishery and note the preservation method used to preserve each species or stock of fish.

\section{Eulachon}

The spawning migration of eulachon brought three resource opportunities: (1) eulachon were an important source of fresh food; (2) the huge catch provided a large supply of fish for preservation; and (3) and spawning eulachon drew large numbers of white sturgeon.

Timing. Eulachon migrate as early as December continuing as late as April, although my records indicate that during the study period, January through early March was the period when eulachon were taken in the largest quantities. When eulachon arrive and which streams they spawn in may vary year to year. Eulachon are reported to miss some seasonal migration periods and may not spawn in particular streams in some years (Smith and Saalfeld 1955; Hinrichsen 1998). Henry reported eulachon arriving as early as December 12,1813 , although he did not trade for eulachon until January 6 , 1814 (Coues 1897:785-786). McDougall reported the arrival of eulachon on February 2, 1812 (Jones 1999:70) and February 13, 1813, the following year (Jones 1999:155). Lewis reports the arrival of eulachon on February 24, 1806 and the beginning of his trade for these fish with the Chinook Villagers (Moulton 1990:346).

Accounts after 1813 do not mention the eulachon fishery. Absence of information could reflect bias in observation, the length of time spent in the study area, subsistence change with Native Americans, or the natural variation in eulachon arrival or numbers. Douglas was in the study area 
through most of February 1826, but did not comment on the presence of eulachon. Townsend was in the study area from October 1835 through October 1836. He does not mention eulachon in his account. Swan (1973 (1857)) in the 1850's, reported on the Chinook's very local subsistence efforts, which did not include trading for eulachon or traveling upriver to intercept eulachon runs on spawning grounds. And, Wilkes (1845) entered the study area in May after the eulachon run. Thus, there is a gap in information on eulachon from 1813 through 1850.

Location. Fishery researchers Smith and Saalfeld (1955) identified the area opposite Oak Point and the Cowlitz River as important eulachon spawning areas (Figure 2-1), although they also report other streams which were not included in the historic record. Oak Point and the Cowlitz River vicinities are the only places identified as eulachon fisheries. Lewis and Clark report the fishery about forty miles upstream of Fort Clatsop which places it in the vicinity of Oak Point. According to Stuart (Rollins 1935:30) the most productive eulachon fishery was opposite Oak Point on the north shoreline of the Columbia River. Franchere discusses a eulachon fishery about 45 to 50 miles above Fort Astoria, which places it in the vicinity of the Cowlitz River. Henry (Gough 1988:635) reports eulachon taken at the mouth of the Willamette River. Eulachon are not reported to spawn at the confluence of the Columbia and Willamette Rivers, but this area is on the migratory path to the Washougal and Sandy Rivers.

Productivity and use. Canoes full of fresh eulachon provided fresh fish and a source of fish for preservation. Lewis and Clark report "great quantities" (Moulton 1999:346); Stuart cites "immense numbers" (Rollins 1935:30); 
McDougall (Jones 1999: 72) notes "many canoes" bringing eulachon downstream; and Henry describes "A wooden canoe with two women and a man passed up, deeply loaded with smelt" (Coues 1897:820). The quantity of eulachon reported in the historic accounts before 1814 is consistent with fishery records from the early 1900's through 1938 reporting tons of eulachon taken by commercial dip netters. Accounts from the early 1900's reported commercial catches of one to two tons per fisher over a twenty-four hour period taken from the Cowlitz River (Smith and Saalfeld 1955:5; Hinrichsen 1998). The large numbers of eulachon supported an impressive commercial catch reported in 1932 as $3,083,357$ pounds, about $1 / 5$ th of the catch of chinook salmon for that year (Smith and Saalfeld 1955:5).

Enormous amounts of eulachon were smoke cured in houses as reported by Lewis and Clark (Moulton 1991:27) and Henry (Coues 1897:820). Eulachon were not processed where they were caught. Historic accounts, such as McDougall's (Jones 1999:72,73, 166), report canoe loads of eulachon transported from the fisheries back to villages providing fresh fish and the stockpiled fish that were smoke cured. These fish were taken during the winter. The winter weather in the study area is cold and rainy requiring drying of these fish in structures.

The trade for eulachon was at times enormous. For example, McDougall's trade in smoke cured eulachon started in April and went through May 1813 (Jones 1999). The fishery and the trade in fresh and processed eulachon lasted for up to four months. Franchere (1967:113) states that eulachon, first as fresh fish and then as smoke cured, were a dietary staple during April, May, and June until the arrival of salmon (Franchere 1967:113). 
McDougall traded'for 353 fathoms of eulachon in 1813 (Jones 1999). Additional trades were also made but the number of fathoms were not listed. McDougall's trade of 353 fathoms of fish was a substantial quantity of fish similar to the commercial catches of the early 1900's. I have computed a rough estimate of the number of fish needed to make 353 fathoms of dried fish: If dried fish, strung through the head, are about $1.5 \mathrm{~cm}$ thick, about 120 dried eulachon would be needed to make up a fathom of fish (fathom $=182$ $\mathrm{cm}, 182 / 1.5 \mathrm{~cm}=121$ fish per fathom). At a weight of $60 \mathrm{gm}$ per fish (raw weight) a ton (90, 200 grams per ton) of eulachon might require a catch of 15,120 fish. A ton of eulachon would yield 125 fathoms of fish $(15,120 / 121=125$ fathoms $)$. Processing this number fish is a significant task, but would yield a substantial volume of fish to trade. McDougall's purchase of 353 fathoms of eulachon represent at least 2.8 tons of eulachon (353/125 fathoms per ton $=2.8$ tons of eulachon).

There would been extremely high processing costs associated with preserving this number of fish, since each individual fish was handled separately. To smoke cure eulachon, each fish was individually skewered through the gills on small sticks and hung in the roofs of houses. Lewis (Moulton 1990:378) reported that fish processed in this manner dry within 24 hours.

It is possible that the lack of information on smoked eulachon after the 1830 's epidemics is a result of population loss. The high processing cost of handling individual fish requires a substantial labor input and organization. McDougall's trade is some fraction of the total trade with the total amount of fish available much greater than what he traded for. It is likely that the loss of 
people inhibited the production of large quantities of smoke dried eulachon after the 1830's.

In the middle and northern part of the Northwest Coast eulachon were rendered into oil (Byram and Lewis 2001) as well as smoke cured. Rendering fish into oil would require a low labor input compared to smoke curing, as individual fish were not handled, rather, fish were processed in bulk. However, there are no references indicating eulachon was processed for oil in the study area in large quantities. Lewis and Clark (Moulton 1990:216) do describe the cooking of fish in wooden vessel using hot stones, remarking that "They also render the Oil of fish, or other animals in the Same manner" (Moulton 1990:216). It is not clear if eulachon were processed in bulk for oil. Townsend noted that seal oil was a condiment used by the Indians in the study area (Townsend 1905:320).

\section{White Sturgeon}

Historic information and fisheries data indicates the sturgeon fishery focused on white sturgeon not green sturgeon. Lewis and Clark (Moulton 1990:344) and Henry (Gough 1988:612) noted two different kinds of sturgeon based on a distinction in taste. This suggests that a small percentage of green sturgeon was likely taken, even though green sturgeon do not feed or spawn in the Columbia River and their presence is limited to the lower river. (Even today, a small percentage of green sturgeon are taken in nets during the commercial salmon and white sturgeon fisheries.)

Even though white sturgeon are an anadromous fish the large resident population present in the Columbia River provided an abundant, predictable resource. Local increases of white sturgeon, resident and marine, may 
develop in areas where sturgeon prey on other anadromous fish, including eulachon, lamprey and spawned out salmon (Haynes et al. 1978:279; DeVore et al. 1995:853; Close et al. 2002).

If McDougall's (Jones 1999) and Henry's (Coues 1897; Gough 1988) reports are combined, there was a trade for sturgeon at Fort Astoria in every month but June (Table 3-2). This suggests a sustained fishery taking advantage of resident and anadromous sturgeon carried out whenever river conditions allowed fishing.

\section{Winter white sturgeon}

Six of my sources, Lewis and Clark (Moulton 1990, 1991), McDougall (Jones (1990), Franchere (1969), Stuart (Rollins 1995), Henry (Thwaites 1966; Gough 1992) and Douglas (Wilkes 1959; Davies 1980) discussed this fishery. The winter white sturgeon fishery was localized, highly visible, and enormously productive providing both fresh and cured meat. This fishery developed because white sturgeon preyed on eulachon during the eulachon's migration to its spawning stream, all of which are located within the study area (Figure 2-1)

Timing. The winter concentration of white sturgeon is clearly associated with sturgeon predation on eulachon. As eulachon increased in numbers and moved to their spawning grounds their presence drew large numbers of white sturgeon. McDougall (Jones 1999) reports a nearly continuous daily trade in sturgeon (Figure 3-2) from January through April of 1812 and 1813.

Location. The winter sturgeon fishery occurred within the area where eulachon spawned. This is roughly from the head of Puget Island to the 
confluence of the Willamette and Columbia Rivers.

Productivity and use. McDougall's record of trade (Jones 1999) provides some of the best evidence of the return rates of this fishery. His counts (Figure 3-2) provide a record of the fishery documenting periods when large numbers of fish were taken. In 1813, between February and April, McDougall traded for more than 300 sturgeon. Not all of the fish were counted; a substantial portion of his catch was simply reported as sturgeon, suggesting that the magnitude of his trade is greater than what is illustrated.

Over a three day period in February, Henry (Gough 1992) counted over 130 sturgeon at three different locations. For some Indian fishers the yield of sturgeon was sufficiently large that methods to temporarily store fish until processed were necessary (Moulton 1990 (6):378). At the Oak Point Village, Henry reports "immense numbers of sturgeon" were tied to stakes driven into the shallows of the river where the fish were kept alive until consumed or processed (Coues 1897:832).

Sturgeon provided an important source of both fresh and cured fish. Sturgeon meat was processed in the winter by smoke curing, probably in the village houses, as was other fish. The smoke cured fish was sold in pieces, the pieces packaged into larger bundles that McDougall called bales. The productivity of the winter sturgeon fishery was sufficient that it supported the Fort Astoria staff of 50 to 60 men for a four month period. McDougall reports that by April 19, 1812 he had acquired a month's supply for the post (Jones 1999:82).

\section{Summer sturgeon}

Swan (1973(1857)) reports that the summer sturgeon fishery was a 
specialist fishery drawing Indian fishers to Baker Bay from Gray's Harbor, the Strait of Juan de Fuca as well as the nearby Chelias Indians to fish with the Chinook Villagers. That guest fishers traveled a long distance to take part in the fishery suggests a reliable, predictable and productive fishery. Fisheries researchers have reported a late summer increase in the number of green and white sturgeon in the lower estuary of the Columbia. Why green sturgeon concentrate is not understood, as these fish neither feed nor spawn in the Columbia River as do white sturgeon. White sturgeon are known to prey upon spawned out fall chinook, other species of Oncorhynchus after they spawn and migrating and spawning lamprey (Haynes et al. 1978:279; DeVore 1995:853; Wydoski and Whitney 1979:18; Close et al. 2002). The summer sturgeon fishery occurs during the period when fall chinook, chum and coho are present. It is probable that white sturgeon are present because of the concentration of their prey in the late summer in the estuary.

Timing. Franchere (Franchere 1969) reported that the summer sturgeon fishery was from August through September. Swan (1973 $(1857): 245)$ reported that it started sometime in late July.

Location. The summer sturgeon fishery is limited to Baker Bay (Jones 1999; Swan 1973 (1855)).

Productivity and use. The Indians may have targeted both green and white sturgeon during the summer fishery, but all of the fish reported in this fishery are large white sturgeon (Franchere; 1967:108; Swan (1973 (1850); 245). Swan also notes a preference for these fish, he states that the sturgeon taken during this fishery are, "more delicate flavored and tender, finer, grained than any sturgeon I have ever seen in any part of the world. The Indians prefer 
them to salmon, but it is much more difficult to take them" (1973 (1850):246).

Swan (1973 (1850):246) also reports that a portion of the sturgeon catch was cut into strips and smoke cured. This method of preserving is somewhat different than the winter smoke cured fish. Winter fish were sliced into large pieces, while summer fish was cut into strips.

This is not a minor fishery, but one that operated on lower yields than the winter sturgeon fishery. McDougall's record shows significantly smaller numbers of summer sturgeon traded than the quantity traded during the winter fishery (Figure 3-1).

\section{Chinook Salmon}

Though spring, summer and fall runs are all the same species, the fish are present at different times, have different degrees of maturity, and are found in different places. Within the study area they were treated as different resources.

\section{Spring and summer chinook}

As long distance migrants, spring and summer fish were immature adults, rich in oil and their flesh in prime condition compared to the leaner more mature fall chinook.

Timing. The first chinook run of the season, the spring run, was reported in most of the historic accounts with entries written from the lower Columbia River in the spring. These accounts provide an estimate of when the fishery for spring run was initiated.

The spring chinook fishery started two to three months after spring chinook first entered the estuary. Lewis and Clark, hoping to follow spring chinook upstream, found no spring chinook at the Cascades on April 1, 1806 
(Moulton 1991:102). Henry (Gough 1992:715) reported Indians fishing for salmon at Willamette Falls on April 9, 1813. McDougall's first trade for salmon was on April 24, 1812, also taken on the Willamette. The following year it was at least a week later, May 2, 1813 (Jones 1999:85;177) before salmon were readily available, although they were still traded in small numbers (Table 3-3). On May 4, 1813 McDougall received a single spring chinook salmon from the Chinooks of Baker Bay (Jones 1999:178), perhaps one of the first spring chinook taken from this area because the Indians insisted on treating this fish with ceremony as it was one of the first they had taken. Wilkes (1845:324) reported spring chinook taken near Puget Island in May 1841 and Swan reported catches of spring chinook in Baker Bay during May, although neither specified the day. However, June was the month when significant numbers of spring chinook were traded.

While it might be expected that the first spring chinook were taken near the Columbia River mouth, historic account suggest that the first spring chinook were taken at the Cascades and Willamette Falls. Secondly, historic information also indicates that fish were not taken as soon as they entered the river, which can be as early as February (Monaco et al. 1990: Table 3), rather they were taken at least two months later. The late start probably has to do with the natural movement of the fish, perhaps a response to river temperature or flows. Certainly, fish taken at the Cascades and Willamette Falls would directly confirm the movement and abundance of chinook salmon in the river.

When the trade shifted from spring to summer chinook cannot be easily stated. The record indicates that the numbers of fish traded simply 
increases through July. As far as trade was concerned the summer chinook fishery was an extension of the spring chinook fishery (Figure 3-3). Fish from the spring and summer runs are both probably present as the summer run enters the river (Fulton 1968). There was no waiting period for summer chinook, their presence did not have to be identified like spring fish, rather fishing for summer chinook would simply continue the fishery as the fish migrated up the mainstem of the Columbia.

There was a break in trade between the summer run and the fall run of chinook. Although fall chinook moved into the tributary streams (Fulton 1968: Table 5) of the study area from mid-August through November, the trade for fresh fall chinook was primarily during October (Jones 1999). Part of the reason for the late trade of fall chinook may have been the August and September trade for sturgeon and large purchases of dried fish in August. Swan comments that the fishery from July through August was not as productive as the fishery in late June (1973 (1857):103), perhaps suggesting fewer available fish during the summer run.

Location. Spring and summer chinook do not spawn in the lower Columbia River main stem or in its tributaries and creeks downstream of the Kalama River ( Figure 2-1). Although all runs of chinook salmon could be taken in the main stem of the Columbia, only the spring run was taken at Willamette Falls because only the spring run spawned in the Willamette River tributaries, only this form could be intercepted at Willamette Falls. Only fall chinook spawned in the tributaries of the study area. The differences between the three runs of chinook salmon affect their resource use.

Productivity and use. Historic accounts provide a sense of potential 
return rates for a variety of gear used to take chinook salmon at certain places. Wilkes estimated that a fisher using a hoop net during the Willamette Falls chinook fishery could take about 20 salmon an hour. He did not provide an estimate of the number of fish taken by gaff. At the Cascades, Stuart suggests that a proficient fisher using a hoop net could take as many as 500 salmon a day (Rollins 1995 (1935):52).

Townsend (Thwaites 1966:365) reported that gaffs took sufficient quantities of fall chinook from Baker Bay that the Indians claimed they had to land three times a day to empty their canoes. Franchere reported to McDougall that one Chinook Villager speared 120 salmon on a November morning in a stream in the vicinity of the Chinook Village (Jones 1999:56). Swan reported that in a four hour period the Indians took over one hundred salmon by spearing (1973 (1857):38-41).

All of these fisheries produced large quantities of fish, however spring and summer run fish were used differently than fall chinook. Spring and summer chinook were consumed as fresh fish with only one exception, McDougall's trade in May for a small quantity of half dried fish from the Cascades. These fish may have been dried with lamprey in small sheds at the Cascades, a method Townsend observed while passing the Cascades on July 3, 1835 (Thwaites 1905: 346-347). It was probably not feasible to air dry chinook salmon within the study area, especially in spring. The climate is $\mathrm{cool}$ and rain showers frequent. Except for this small quantity of half dried fish, all of McDougall's trade for salmon through July was for fresh fish (Jones 1999).

The bulk of upriver dried fish were brought downstream and traded in 
August and September when there was very little trade in fresh salmon (Figure 3-4). Given this period these fish are probably from the summer chinook run. McDougall was able to obtain dried fish from local trading partners, such as the Chinook Villagers as the summer progressed, but his first large trade in dried fish was procured by his staff who were sent up river to acquire these stores.

A few days before August 15, 1813 McDougall dispatched a crew to trade for dried fish. He expected the crew to be gone for an extended period of time because they needed to travel at least to the Cascades. He was surprised when they returned early with over 2000 dried fish acquired from the Multnomah Village on Sauvie Island (Jones 1999:210).

Some of these dried fish could have been produced at the Cascades. Stuart (Rollins 1995:52) and Townsend (Thwaites 1966: 346-347) both report that the fishery for chinook salmon at the Cascades was substantial and the weather, though not as dry as eastern Oregon was drier than the coastal area, benefiting from the strong warm winds blowing down the river from the east. While the Cascades may be a source of dried fish in the late summer, none of the accounts explicitly state that dried fish came from this place and the only method of preserving salmon at the Cascades was smoke curing the fish in lodges noted by Townsend (Thwaites 1905: 346-347).

\section{Fall chinook}

Fall chinook fisheries produced fish for fresh consumption, as well as preservation and storage. In the study area fall chinook were ready to spawn and had a lower fat content because they were at the end of their life-cycle. Schalk (1986:13 citing 1984) suggests that across the Pacific Northwest, 
there may have been a preference for curing fall chinook because the fish has a lower fat content.

There are no reports of separate structures used to cure fall chinook in the study area. Townsend reports, October 25,1834 , salmon curing in a Chinook house near Willapa Bay (Thwaites 1978:256). Curing fish in village houses with heat and smoke was the solution to the rainy fall and winter weather of the western Cascades. The requirement to cure fish in a house might have imposed a limit on the number of fish that could be preserved by this method. Many accounts note the huge quantity of dried salmon produced at The Dalles and Celilo using drying racks; these were much simpler structures to construct than a drying shed or a house. The available area used to smoke cure fish, the square footage of a house, may have limited production, while air drying fish on racks outdoors would not face that limitation as long as there was room to place more drying racks.

Resource variation in chinook salmon stock. Three stocks of chinook salmon migrate through the study area, each present in abundance at different times. Spring and summer fish were consumed mostly as fresh fish, and were not chosen for preservation in the study area except at the Cascades where they were smoke cured in lodges.

Many of the important tributaries of the Columbia in the study area are fall chinook spawning streams and are also the locations of Chinook, Cathlamet and Multnomah Villages (Silverstein 1990: Figure 1). The proximity of fall chinook spawning streams to villages reduces the cost of obtaining these fish because the catch does not have to be transported a long distance for consumption or preservation. Once taken, it would have been an easy 
matter to bring fall chinook to nearby villages for butchering and smoke curing. Spears, gaffs and hoop nets used to take single fish in stream spawning habitat could be highly productive. Hundreds of fish could be taken in a day. In addition, this gear could easily allow selection of mature or bright fish depending on how they were going to be used.

Thus, the resource value of fall chinook is important for these three reasons: (1) large numbers of adults use spawning habitat in the local streams of the study area (Fulton 1968: 5); (2) fish could be taken in close proximity to villages; and (3) gear allows fishers to select between lean and fatter fish, choosing fish to fill a particular need. As a result, spring and summer chinook did not have to be preserved, but could be taken in numbers appropriate for fresh consumption always in anticipation that some could be cured for storage.

\section{Minimally Documented Resources}

\section{Chum}

Lewis and Clark (Moulton 1990), McDougall (Jones 1999), Franchere (Franchere 1967), Stuart (Rollins 1995), Henry (Thwaites 1966; (Gough 1992), Douglas (Wilks 1959; Davies 1980) and Swan (1973 (1857)) provide information on fisheries for chum. In combination these citations note four things about chum: their physical appearance, their abundance in local streams, the method of preservation and comments that the traders found chum the least appetizing of all the fish traded. Even though these references to chum are sufficient to define a fishery, the actual number of citations from these sources are limited to a few comments. Chum are reported, but the accounts do not include observations of the fishery or any information on the 
productivity of the fishery.

Chum were abundant in the Columbia River and supported a significant commercial fishery in the early 1900's. Commercial records discussing the productivity of the fishery varied partially because chum abundance naturally varied year to year, and partially because the fish was not a favored commercial product (Fulton 1970:29).

The abundance of the chum during the period of my study is highlighted by Stuart's (Rollins 1995:8) remark that chum fill the small streams of the study area and Swan's (1973(1857):140) comment that chum cram "every river, brook, creek, or little stream" of Willapa Bay.

Timing. Chum arrived in the fall, following fisheries that concentrated on fall chinook, coho, sturgeon and perhaps steelhead. Both Stuart (Rollins 1995:8) and Swan 1973(1857):140) reported chum were present from August through December.

Location. Stuart (Rollins 1995) reported chum present in the small streams within the study area. Swan 1973(1857):140) states that in Willapa Bay, "every river, brook, creek, or little stream" were filled with chum.

Productivity and use. These fish are reported as abundant, but there are no comments on how many fish were taken. Chum was an important fish because it was easy to catch and preserve. Stuart reports that these fish are "smoked and laid by as stores for the dreary months of January and February" when no other fish are available (Rollins 1995:8). Douglas (Wilks 1959:239240) notes it is lean and like pine bark when dried. Although not a favorite food of Douglas, this fish was an important resource eaten when other fish could not be caught. 
Cooper and Suckley (1859:341) stated that Puget Sound Indians preferred chum to other fish because it was lean and therefore could be quickly smoke cured in the fall. Chum may also have been valued on the Columbia River for the same ease of processing. Similarly, Schalk suggested a potential preference for fall chinook as the salmon selected for preservation because of its reduced fat content.

Chum played a small part in the trade economy of the study area and thus it is difficult to define its role. It is clear that chum was a resource of some value as they were traded as fresh and preserved fish. Fish that was preserved must have been taken in quantities sufficient to support the cost of the effort to take them. If only a small number of fish were taken, they would most likely have been consumed as fresh fish. In the study area all of the requirements for using chum as a preserved fish were present: large numbers of fish were available, they could be taken in the tributaries of the study area, gear used to take these fish could easily take large quantities and the fish's physical state, low fat content, was appropriate for smoke curing indoors during the winter.

\section{Pacific Lamprey}

Townsend's is the only account that discusses lamprey although Stuart (Rollins 1999) noted the availability of this fish. Townsend (Thwaites 1852) reported thousands of lamprey taken at the Cascades. Pacific lamprey were once abundant in the Columbia River and its tributaries (Mattson (1949; Michael 1984). There are sufficient numbers of lamprey and local opportunities that lamprey could have been an important fishery, but there is little historic information to support this statement. 
Timing. On April 24, 1834 Townsend reported, "fragments of ...lamprey eels" as part of the stores in an Indian lodge near the Clackamas River's confluence with the Willamette. At the Cascades, on July 3, 1834 Townsend reported "great numbers of lamprey" taken at the Cascades (Thwaites 1966:345-347). These fish are present from April through June, the same period described by Close, et al. (2002:21) as the migratory period of Pacific lamprey.

Location. Townsend's account of a huge lamprey catch drying at the Cascades is the only record of this fishery. He noted lamprey in the stores of a house on the Willamette River, but did not report a fishery.

Productivity and Use. Townsend (1835) reported the smoke curing of thousands of lamprey in lodges of the Indians at Cascades. There is no statement of where these fish were taken, although they probably were caught at the Cascades. The numbers of these fish, thousands, implies a major fishery, although there are no remarks in the historic record of a lamprey trade with the fur trading posts.

\section{The Timing of Fisheries Over the Year}

The decision to move from one fish resource to another is indicated by evaluating the fisheries over a year of subsistence effort. This information may show a preference for certain fish, how often certain fish were taken and for anadromous fish, at what point during their migration they were targeted.

Examining the fisheries from this perspective also connects preserved fish to its source (Figure 4-1).

Large quantities of sturgeon and eulachon were taken during the winter fisheries primarily from January through March, although Henry (Coues 
1897:786-787) reported the unexpected early arrival of eulachon in December 1813 which started the fishery earlier than usual. The key factor in this fishery was sturgeon predation on eulachon during their spawning migration. Smoke cured eulachon was traded shortly after the big catches of eulachon were reported, followed by smoke cured sturgeon. Much of McDougall's trade in cured sturgeon was during April with no cured sturgeon traded in May.

Steelhead were available between the eulachon-sturgeon fisheries and the spring chinook fishery although the record indicates a limited use of these fish. Lewis and Clark (Moulton 1991:102), McDougall (Jones 1999) and Henry (Gough 1992:698-699) took advantage of a small number of steelhead (salmon trout/white salmon trout) traded from March through May. Winter steelhead spawn in the tributaries of the study area (Fulton 1970; see Table 2-5) and were taken in these locations by spear. Steelhead were traded only as fresh fish, although the fish supported a commercial fishery from the late 1800's through the early 1900's (Fulton 1970) and could have been smoke cured. Once spring chinook enter the trade, steelhead are no longer traded, although they are still present and could have been taken.

The spring and summer fisheries focused on chinook salmon. Though spring chinook are present in the estuary as early as February there are no reports of a trade for chinook until early spring. From February through April fisheries focused on eulachon and sturgeon.

The spring chinook salmon fishery may have started in late April, but the trade was irregular with only a small number of fish traded. By May fish were being traded with some regularity with more fish traded in June, but it was the trade in July and August that provided the bulk of the fresh salmon. In 
August the trade in fresh salmon dropped significantly, while the trade in dried fish continued. Fresh chinook did not become a significant part of McDougall's trade until October.

Dried fish were a part of McDougall's (Jones 1999) trade in June, August and September (Figure 3-4). He obtained only a few partially dried fish in May, many more in June, a few in July, and the bulk of his supply in August and September. The smaller trade in July, was probably a reduced effort by McDougall and staff, rather than a decline in availability. The bulk of dried fish was traded down river with the Cascades mentioned as the place where trades were made. It is not clear whether fish were dried at the Cascades or whether it was imported to this place from up river. Clearly, most of the dried salmon was produced outside of the study area.

In late summer the summer sturgeon fishery started. During August and September, McDougall traded for sturgeon. Swan noted that this was a selective specialist fishery that occurred during the start of the fall chinook salmon migration and ended about the time coho and chum appeared. The summer sturgeon fishery provided fresh fish and smoke cured sturgeon that had been butchered into strips (Swan 1973 (1857): 246).

A few fall chinook taken in August and September were traded to McDougall, but most of his fresh catch was traded during October. It could be that his trade for dried salmon took precedence over a trade for more fresh salmon. Indeed, during this period fresh sturgeon and steelhead were available. Thus, other fish provided a break from summer and fall salmon.

As winter approached, smoke cured chum salmon was available. For most of the records it is not clear what salmonid was being traded with a few 
exceptions. By January, Henry reports the salmon was "wretched stuff, scabby and of various colors particularly the Tail part" (Gough 1988:632). These were the last fish traded to Henry.

\section{Gear}

Gear has an important relationship to place and to fish. Much of the gear was used to intercept fish as they moved in large numbers from place to place. Intercept gear was typically used in shallow water habitat or when fish were near the water surface or where fish were forced into constricted area, such as rapids or at falls. Other gear relied on bait to take fish by using knowledge of fish feeding behavior and places where they were liable to forage.

\section{Scoop Net}

The scoop net and the eulachon rake were used to take eulachon. These implements depended on the presence of dense schools of eulachon. The eulachon scoop net was probably a specialized net with smaller mesh than the hoop net used for salmon, but the details of this net are not reported. Dip nets were used in the commercial eulachon fisheries of the 1940 and 1950's. Hinrichsen (1998:6) states that the Cowlitz commercial fishers used a 10 foot pole with a 16" diameter hoop and light net to take eulachon. He believes the commercial net was derived from the net used by the Indians (Hinrichsen 1998:7).

\section{Hoop Nets and Platforms}

Stuart (1935:52) and Wilkes (1852 (4):345;380) discussed the use of hoop nets and platforms as specialized combinations of gear used to take chinook salmon at the Cascades and Willamette Falls. Hoop nets may have 
been similar in basic form to scoop nets, but it is likely that hoop nets were bigger because they were used to take larger fish. In addition, some of the hoop nets were not permanently open but slid on the hoop closing around a netted fish.

At the Cascades, the Columbia River narrows and the current becomes swifter. Migrating chinook moving along the shoreline swam where current and flow were reduced. Fishers modified the near shore rocky substrate by shifting boulders and rocks to form channels aligned parallel to the shoreline. Platforms were set perpendicular to the shoreline over the channels and hoop nets were placed at the upstream edge of the platform. The fish were taken as they swam through the channels into the net. Thus, fishing adjacent to the shore for fish slowed by the current and confined by the channels enhanced the hoop net fishery.

At Willamette Falls spring chinook were taken with hoop nets from platforms placed around the base of the falls. At the base of Willamette Falls fish are stacked up as they stage to make their leap over the falls. Those that do not make the crossing fall back into the pool at the foot of the falls joining newly arrived fish. As a consequence of this setting fish were concentrated at the pool of the falls providing an opportunistic target for the hoop net.

McDougall reports that his crews used hoop nets in the streams around the Cathlamet and Chinook Villages to take fall chinook, the same gear the Indians used (Jones 1999:56). (There are no references to platforms on these streams in the literature I cite.)

\section{Funnel or Drag Net}

Franchere (Franchere 1967) and Henry (Coues 1897) are the only 
accounts to report the use of a specialized gear, the funnel net to take sturgeon during the winter fishery. A large cone shaped net was dragged along the riverbed behind a canoe as the canoe drifted downstream. Sturgeon were drawn into the net by the white lure (Franchere says "white object"; Henry noted a bundle of white feathers) tied to the apex of the net which imitated a spawning or spawned out eulachon.

The funnel net was only used to take sturgeon. The spawning habits of eulachon probably drew sturgeon into the shallow water. According to fishery research, sturgeon will forage in water as shallow as 5 meters, especially at night (Parsley and Popoff 2004). Thus, the net was probably used in shallow water, at night, in areas where spawning or spawned out eulachon were abundant.

\section{Seine Nets}

Lewis and Clark (Moulton 1990), Franchere (Franchere 1967), Stuart (1935), Henry (Coues 1897) and Swan (1973 (1857) all report that seine nets were used to take salmon (Lewis and Clark report that seines were used to take charr and trout as well.) Of these sources only Swan discusses the method of net construction and its operation. Moreover, except for Swan, there is only Stuart's remark that the seine net was used in shallow water and Lewis and Clark's (Moulton 1990) comment that "the common streight net" was used in the marshy islands. As most of these accounts fail to elaborate further on the use of nets I am uncertain how important seining was as a method of taking salmon. Even, McDougall's (Jones 1999) detailed record of the salmon trade does not account for where or how most of his fish were taken. 
Swan (1973 (1857)) provides specific information on beach seining in Baker Bay where seine nets were drawn over subtidal beaches. If Swan's record is the appropriate model for the whole study area, and noting Douglas' (Wilks 1959:129) comment that seines were limited to places where the substrate would not snag nets, shallow areas near beaches free of snags would be important fishing locations.

The migratory routes of chinook salmon through the mainstem are diverse enough that fish could be taken in a variety of places by seining. Some follow the shoreline, others move up the main channel or take side channels formed by islands in the main stem. Thus, though beaches are noted in the record, there are potentially many places where chinook salmon could be taken by long nets, seines.

Shorelines and side channels, however, were problematic places to fish. Commercial gill netters faced with the problem of limited gillnet drifts in the main Columbia River channel undertook an intensive and sustained effort using heavy equipment and divers to remove snags. This work opened side channels and areas near islands for fishing (Martin 1994). The effort had to be undertaken each season otherwise the gill net drifts would be unusable. The historic Indian fishery would have required the same effort to use seine net fishing gear outside of beach locations as did the commercial fishery. This information suggests that seine net fishing in the Columbia River during the historic period was limited to the beaches.

It is also possible that seines could have been set in the deeper portions of the main channel where river depths would keep nets from snagging on the river bottom, but the record does not include any accounts of 
the use of seines in this setting.

Swan (1973 (1857) provided the only account of net manufacture and rigging. (A few accounts, Lewis and Clark (Moulton 1990: 214) and Franchere (Franchere 1967:112) for example, mention the kind of fiber used to manufacture nets and the lengths of seine nets.) One of the important notes Swan provides is a brief remark about net weights. The net weights the Chinook Villager's manufactured seem to be an expedient form made by striking a notch from opposite sides of a flat beach pebble. (I assume that these are flat ovid shaped pebbles.) This form contrasts with a large group of notched and pierced pebbles (Figure 4-2) commonly referred to as net weights in many archaeological reports for the Portland basin (see: Warner and Warner 1975; Pettigrew 1977; Dunnell and Campbell 1977 for examples of net weights).

\section{Eulachon Rake}

Henry. (Coues 1897:838) and Franchere (Franchere 1967:113) described the construction and use of the eulachon rake. Fishing gear and the dense schools of eulachon kept handling costs to catch the fish relatively low. The rake took advantage of the dense schools of eulachon by sweeping through the fish, impaling them on the pegs and dropping them into a canoe.

\section{Gaff}

Historic accounts document the use of the gaff to take sturgeon, spring and fall chinook. Swan (1973 (1850):245) is the only source discussing the gear used to take sturgeon in the summer fishery. Franchere (Franchere 1967) reported the summer fishery in Baker Bay but did not describe the gear. Indians gaffed sturgeon from a canoe drawing the sturgeon into the canoe 
when it was worn out. On the Fraser River, sturgeon were taken by similar method except the hook was replaced by a harpoon head (Stewart 1977).

Swan (1972(1857):246) notes that gaffing sturgeon from a canoe was not a common practice, but the work of specialists. Expertise was required to find the fish, strength was required to play the sturgeon from a canoe and keep the canoe from tipping and skilled handling of the catch was necessary to roll large sturgeon into the craft.

Townsend (Thwaites 1966), Wilkes(1852) and Swan (1973(1857)) reported the taking of spring and fall chinook with gaffs from canoes. During the spring run, chinook were gaffed at Willamette Falls from canoes tied to pilings near the head of the falls, as the fish jumped to clear the falls. These fish were probably slowed by the exertion to leap the falls and by the current at the head of the falls, enhancing the use of the gaff by retarding fish movement.

Gaffs were trailed behind canoes in the estuary to snag salmon when they were close to the water surface (Thwaites 1966:365). Gaffs were also used in the deep pools at the confluence of tributary streams and in tidally influenced portions of tributaries, especially in deep channels. In this situation the gaff was used as a probe to feel for the fish. When fish were found it was impaled on the hook and retrieved by a line tied to the hook (Swan 1973 (1857:137)).

\section{Fishing Spears, Gigs}

Lewis and Clark and Stuart (Rollins 1995) report the use of gigs or spears to take salmon in shallow water where the fish were visible. Lewis and Clark report gigs used to take salmon in creeks near Fort Clatsop (Moulton 1990:118, 211). 
Spears were used to take chum in its preferred spawning habitat.

Stuart (Rollins 1995: 8) reports chum were taken in shallow streams in the vicinity of Fort Astoria by spears. Spears are selective gear and may have been used to take particular fish, such as those in better physical condition.

\section{Hook and Line}

Franchere (1967:112) is the primary source of information on set-lines used to take sturgeon, although Henry notes the use of this gear, but did not describe it. The set-line consisted of a hook attached by a leader to a main line. One end of the main line was tied to the shore and anchored in the river with a buoy suspending the main line above the river bed. Hooks baited with a small fish were incrementally spaced and tied to the mainline.

Set-line gear is versatile, it can be placed in a wide range of habitat and can be retrieved during any kind of weather. Set-line gear is also selective gear targeting large white sturgeon. Fishery researchers use set-line gear to sample sturgeon populations (Beamesderfer et al. 1989: Figure A-3.2; Ramano and Rein 2001:6). The sturgeon caught on set-line are larger than those caught in gill nets. Sturgeon forage in shallow water at night (Parsley and Popoff 2004). Henry observed set-line gear that was placed at night and retrieved in the morning. Using this gear in the manner reported took advantage of sturgeon foraging behavior.

Hook and line were also used to take trout. Swan (1972 (1855) reports trout taken with hooks baited with salmon roe. This method took advantage of resident trout foraging on salmon roe as it drifted down stream from spawning salmon,

The record is not clear what other fish, besides sturgeon and trout, 
were taken with hook and line. Lewis and Clark reported that metal trade hooks had replaced the traditional acute angle bone hook within the study area, but they did not specify which fish were taken by this gear.

Franchere (Franchere 1967) and Swan (1972 (1855)) report the Indians forging their own hooks from traded steel. This information suggests that hook fishing was important gear and probably was under reported in the historic record.

\section{Resident Fish Use and Archaeological Fauna}

Faunal data from the archaeological record of the Portland Basin suggests the use of resident fish and fish as small as minnows (Saleeby 1983 and Butler 1992;1994;1996;1998; 2000b; 2001). In some archaeological contexts minnows are $1 / 3$ to $1 / 2$ of the identified taxa.

Butler (2000) has argued that resident minnows and suckers were lower ranked fish. These fish would only become an important component of subsistence when the relative abundance of higher ranked fish, such as salmon and sturgeon declined. One possible cause of the decline in higher ranked fish might be intensive predation on them by large human populations, a situation that occurred prior to historic contact with Europeans. The historic accounts I cite have minimal information on the use of small resident fish. Franchere's mullet is the only small fish reported in the historic record. (The only other resident fish taken was trout as noted by Henry (Gough 1992) and Swan (1972 (1855)).

Aside from lower ranked fish, there is another possible source from which minnows might have entered the archaeological record. Minnows and other small fish could be part of an incidental catch. Fish taken by nets, if the 
mesh is small, could include an incidental catch of small minnows along with the fish intentionally taken. Eulachon were taken with a hoop net designed with a small mesh sized to take this small anadromous fish. At the locations where eulachon spawn, minnows and other small fish probably foraged on eulachon eggs. Sweeping nets through schools of eulachon, could also net whatever other fish might be present. It is very likely that schools of spawning eulachon would draw a variety of fish foraging on eulachon eggs. Since canoe loads of eulachon were taken back to villages for processing, other fish incidentally netted and dropped into canoes may also be present. Minnows might then be discarded as the canoe load of eulachon is sorted and processed.

\section{Discrepancies Between Historic and Commercial Fisheries}

Five taxa that were important to EuroAmerican Columbia River commercial fisheries of the late 19 th and early 20 th century are discussed minimally or not at all in historic accounts I have reviewed. Coho is an abundant fish in the study area. Fulton (1970:19) reports a commercial catch of $3,600,000 \mathrm{~kg}$. about 800,000 fish, taken in 1925 . The commercial catch records and the fact that coho spawn within the study area clearly indicates coho could have been a significant resource, but there is only Lewis and Clark's (Moulton 1991) reference to this fish in the records I cite.

Sockeye salmon was not recorded in the fisheries. Sockeye are present during the migration of summer chinook and may have been simply ignored in favor of the larger fish. Aside from seining in the main stem, the only place sockeye could have been taken in the study area would have been the Cascades. Access to this fish was limited and may have been over 
shadowed by the hugely productive chinook fishery. Lack of information in the historic record of a sockeye fishery may be an example of a fish that was simply not counted or recognized because the chinook numbers dominated the trade.

Herring are reported as common in the study area (Monaco et al. 1990: Table 3) and Lassuy and Moran (1989) report that they spawn within the lower Columbia River. Swan (1972 (1855): 27) reported a herring fishery in Willapa Bay, but there is no record of a fishery for these fish in the study area. This is surprising because these fish spawn in the early spring and would have been available after the eulachon-sturgeon fishery and before the arrival of spring chinook. The historic record would suggest that the lower river herring were not in sufficient numbers to support a fishery.

Lamprey supported a commercial fishery at Willamette Falls during the spring months in the 1940's taking 50,000-150,000 kg of lamprey (Mattson 1949:27). Michael (1984) reports lamprey spawning habit in the tributaries of the study area. He counted 13,000 lamprey spawning in the Kalama River during an investigation of repeat spawning of these fish (see also Wydoski and Whitney 2003:35). Townsend provided the only account of a lamprey fishery. He noted that at the Cascades thousands of these fish were taken. Even though thousands of these fish were taken there is no reported trade for these fish.

Eulachon were an important resource and the record of trade for these fish is well documented before 1814. However, there are no reports of a fishery for eulachon after 1814. Neither Douglas (Wilks 1959) nor Townsend (Jackson 1978) mention these fish. Swan (1973 (1857)) does not mention 
these fish either, although in the early accounts, the Chinook Villagers were one of the main suppliers of this fish to Lewis and Clark (Moulton 1991) and to McDougall (Jones 1999) and Henry (Gough 1992). Absence of these fish in later records may be a consequence of reduced human population in the study area after 1830 's. Processing huge amounts of these fish probably required a large number of people to prepare these fish.

\section{Summary}

My analysis of the historic record has provided important details on the fisheries of the study area. It is evident that sturgeon, eulachon, and chinook salmon provided the bulk of the resource and the source of fish that were preserved. It is likely that chum and lamprey also made important contributions to the economy, but discussions of chum are not well developed. What contribution lamprey made is also not evident even though thousands of these fish were taken at the Cascades. These fish were not traded to the EuroAmericans.

I have also noted the minor fisheries, such as steelhead, and have suggested that some of those fish could have made a larger contribution to the local economy. Further, some potentially important fish, such as herring and coho, are not discussed in the historic documents I cite.

Though it is certain that the fish discussed in these documents were an important part of the economy, these records probably do not include all of the fish used as resources by Native Americans in the study area. The resources discussed in the historic record are primarily those that provided large catches and were preserved. Preserved fish were very important for the fur trading posts because these fish sustained the fur trading enterprise and 
its staff. While small numbers of other fish were traded it was the fish that were taken in large numbers and preserved that buffered the fur companies staff against the natural variation of this food supply and their trading partners, the Indians who supplied it. 


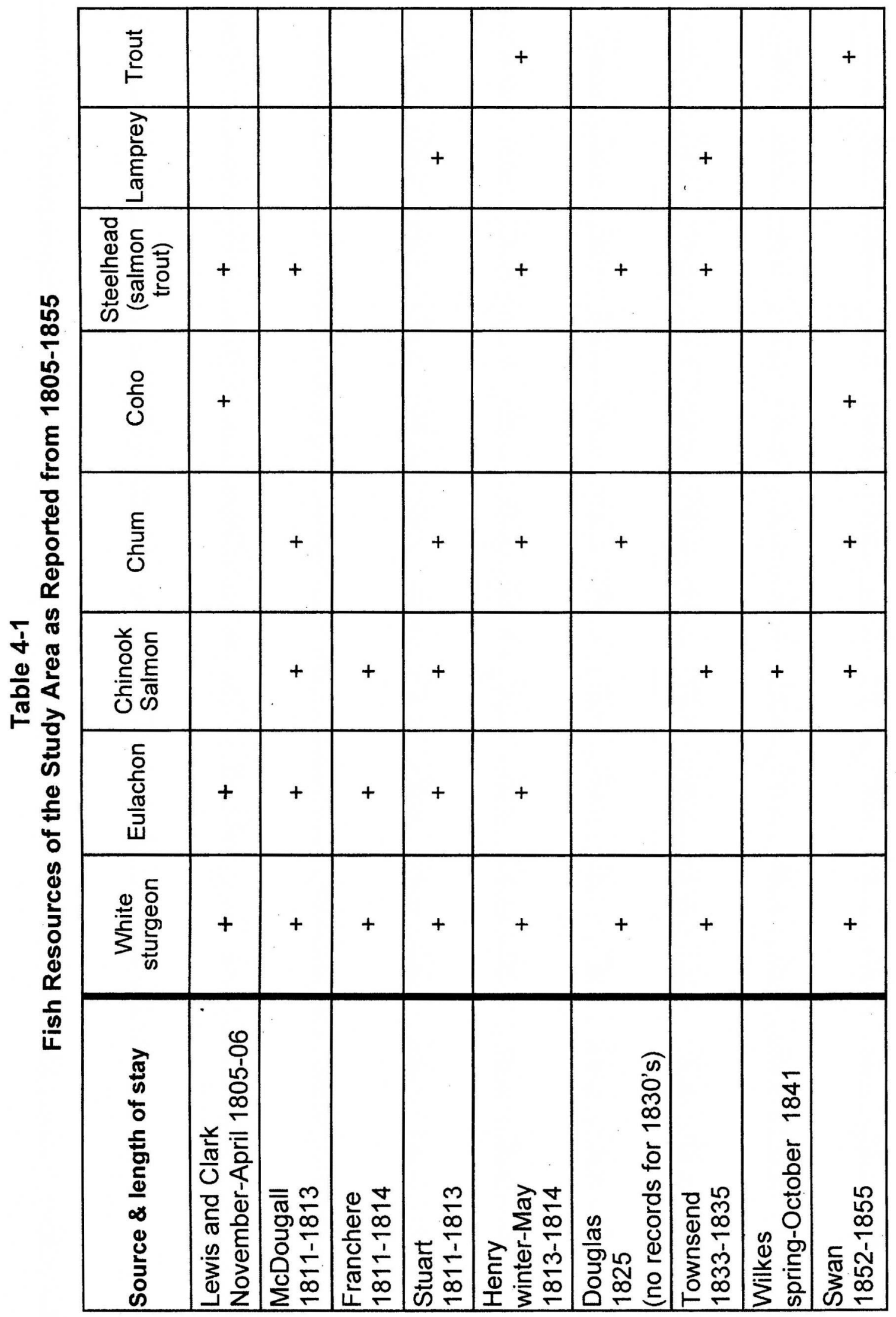




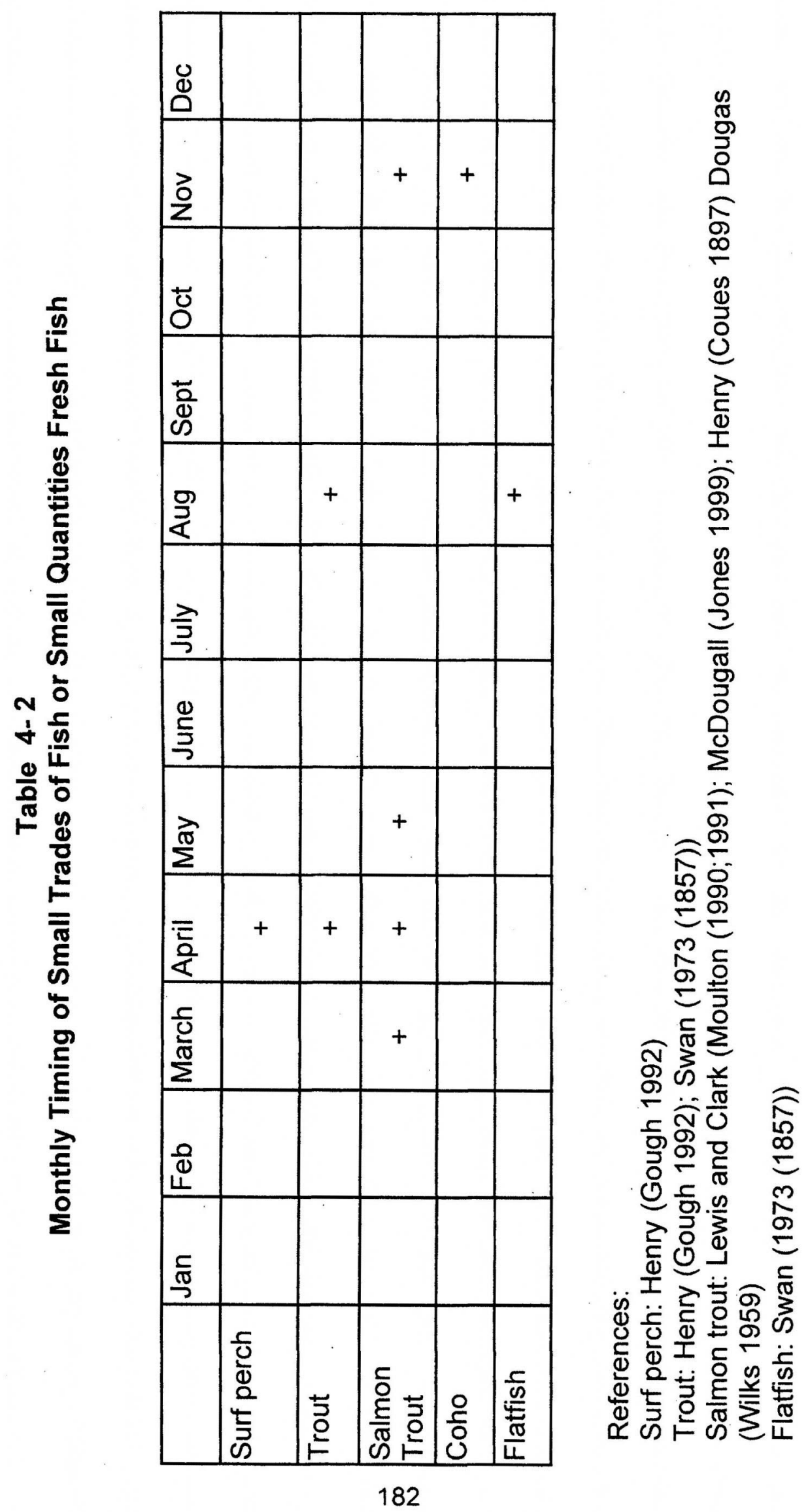




\begin{tabular}{|c|c|c|c|c|c|c|c|c|c|c|}
\hline & 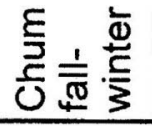 & & + & & + & + & + & & & + \\
\hline & 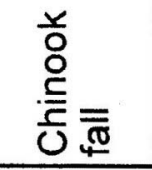 & & + & & & & & + & + & + \\
\hline & 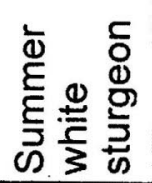 & & + & + & & & & $\therefore$ & & + \\
\hline $\begin{array}{l}0 \\
\frac{8}{0} \\
0 \\
0 \\
0\end{array}$ & 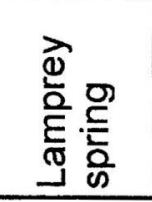 & & & & + & & & + & & \\
\hline $\begin{array}{l}2 \\
0 \\
8 \\
8 \\
0 \\
0\end{array}$ & 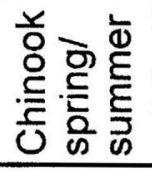 & & + & + & + & & & + & & + \\
\hline$\frac{}{\frac{2}{2}}$ & 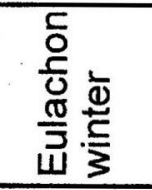 & + & + & + & + & + & & & . & \\
\hline$\frac{x}{\frac{n}{2}}$ & 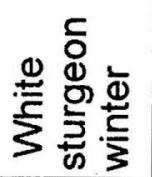 & + & + & + & + & + & + & & & \\
\hline & 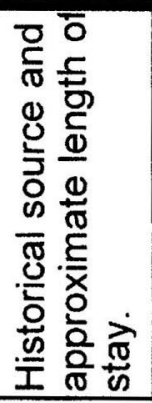 & 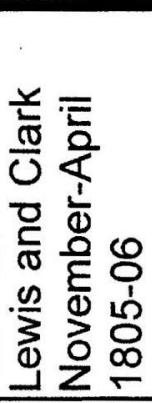 & 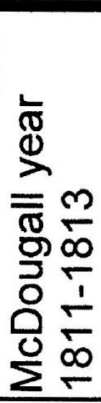 & $\begin{array}{l}\frac{1}{4} \\
\frac{1}{\infty} \\
\frac{5}{0} \\
\frac{1}{5} \\
\frac{1}{0} \\
\frac{1}{1} \\
\end{array}$ & $\frac{m}{\frac{\infty}{\infty}}$ & 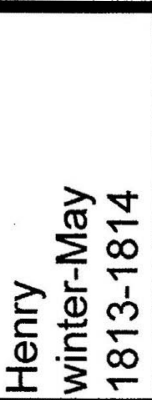 & 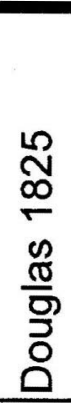 & 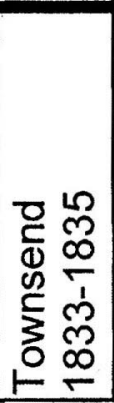 & 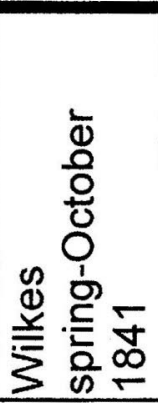 & 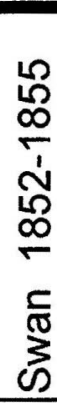 \\
\hline
\end{tabular}



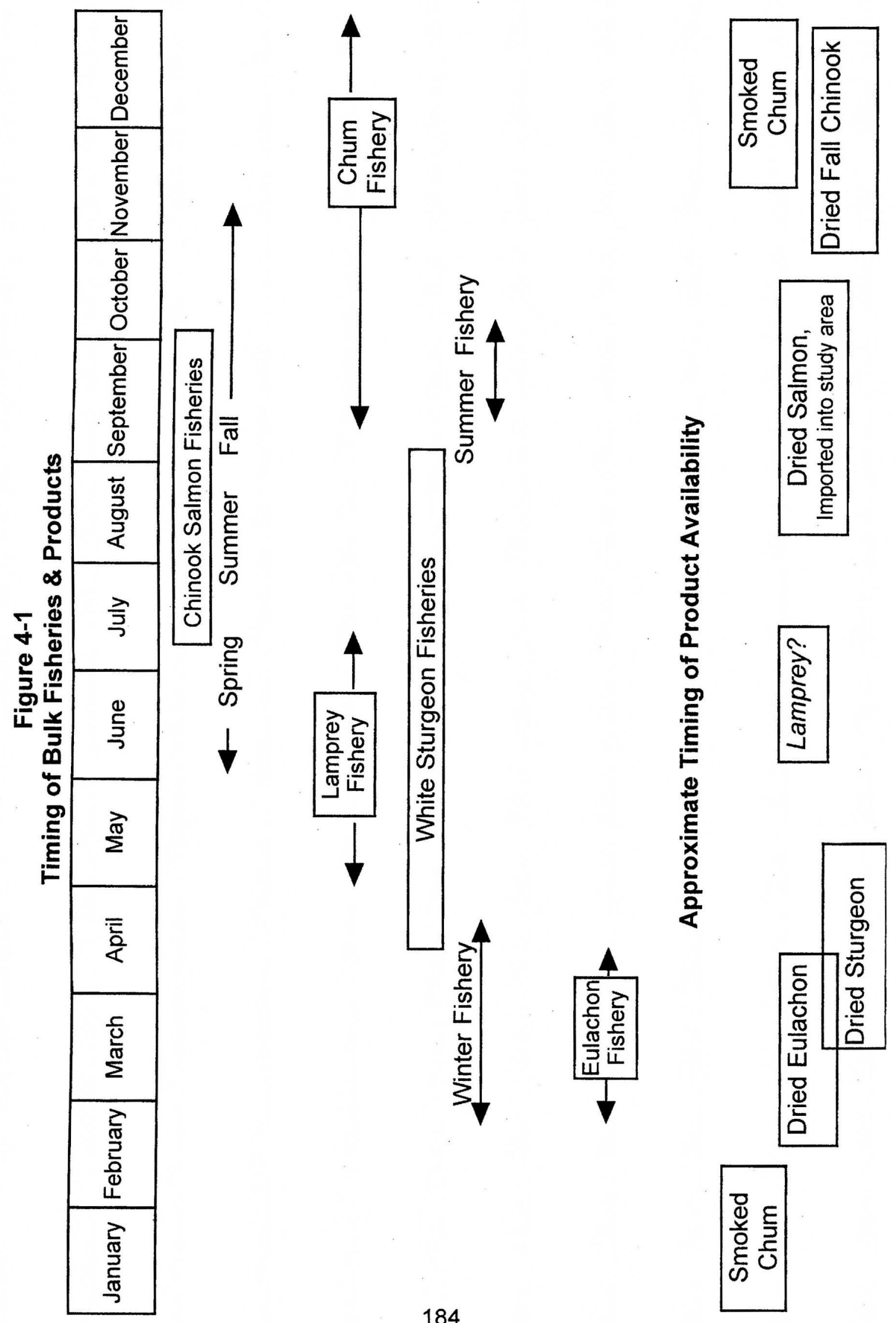
Figure 4-2

Swan's Net Weight

No Scale

(illustrations by G. Martin)

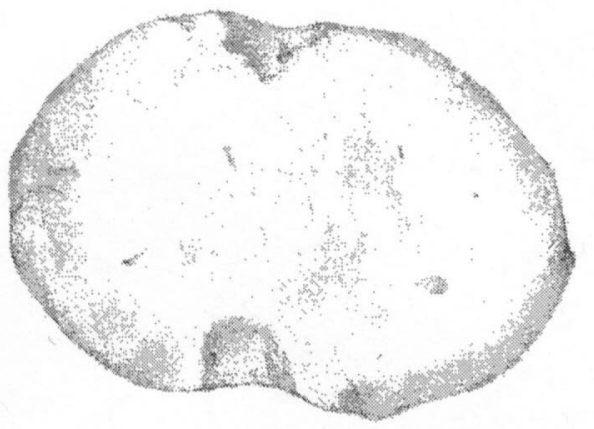

Notched Pebble Net Weight

artist interpretation

Swan (1973 (1857): 104

So-called net weights from Portland Basin

(see Pettigrew 1977; Dunnell and Campbell 1977)
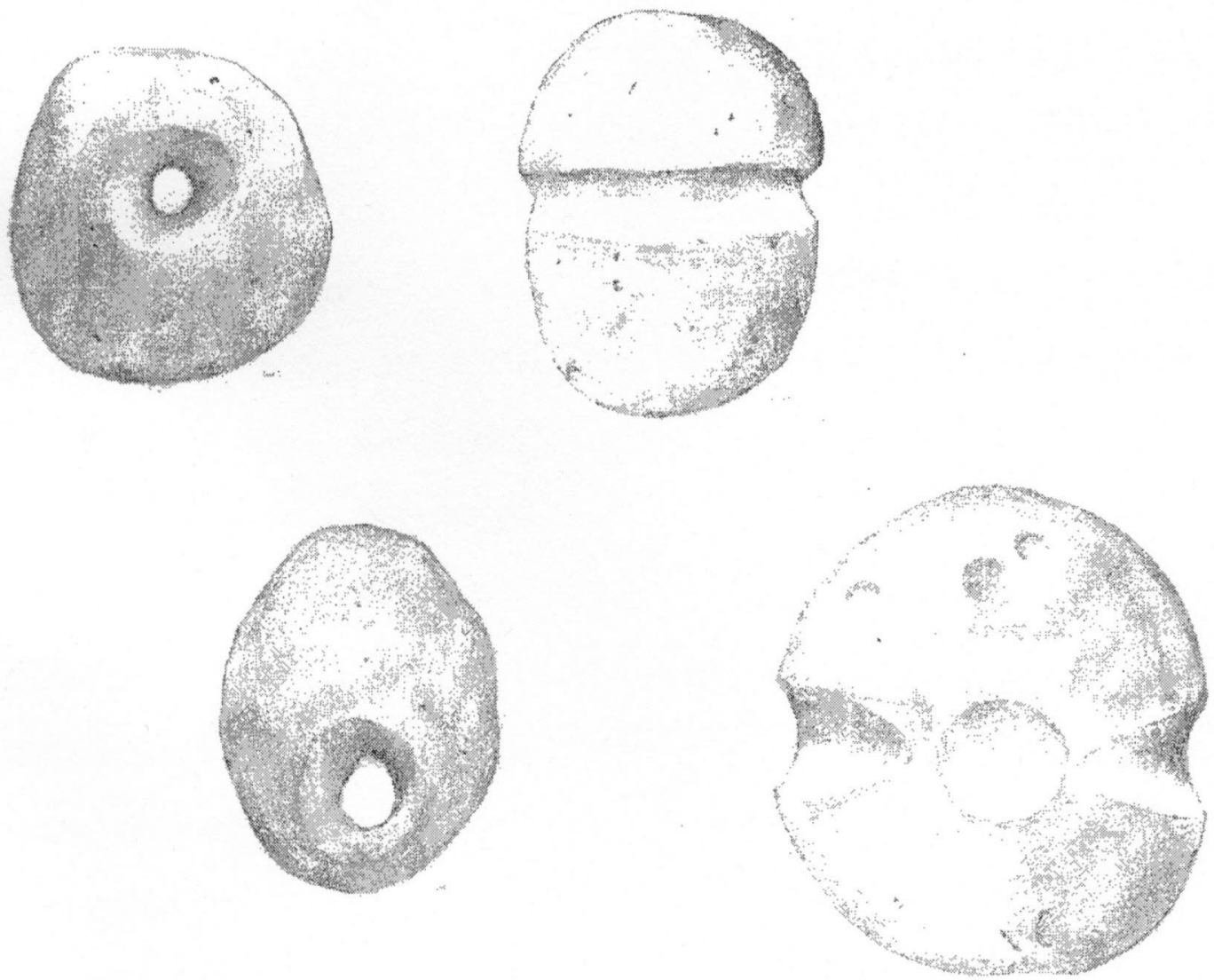


\section{CHAPTER 5 \\ CONCLUSION}

My thesis examined the Indian fisheries of the lower Columbia River from the 1790's through the 1850's using trade accounts and descriptions of procurement activities from administrative records and journals. The documentation for this study comes from nine primary sources written over the period when native cultures were significantly impacted by contact with EuroAmerican explorers and traders who brought devastating diseases to Indian communities (Boyd 1975).

The historic records I cite also provide baseline information on the distribution and abundance of fish selected as resources prior to the major environmental changes that came with EuroAmerican developments in the late 19th and 20th centuries (Netboy 1980). Information on the natural history of fish provided clues used to identify species and stocks of species.

Baseline information and the details of the natural history of fish help explain the organization and deployment of Native American fisheries thoughout the year. This information is particularly important in my discussions of place and the gear used to take specific fish.

In the Introduction I raised these questions: What fish besides salmon were chosen as resources? How were the various species of salmon used? Given the fish used as resources: Where were they taken? What gear was used to take them? When were the various fisheries initiated? Is there evidence of specialized gear used to take particular fish? How productive were the fisheries? And how were these resources incorporated into the 
economy? Gathering information based on these questions has provided an account of the place of particular fish in the economy of the study area. Notes on trade were only part of the information available in the historic record. Many of the accounts include observations on fishing gear, where and how it was used and specific information on how some of the fish were preserved.

The trade with local Indians for food supported the fur trading post at Astoria, the field crews who traded with the Indians for furs and those who explored the Pacific Northwest looking for other trading opportunities. (The post also employed crews to hunt and fish as part of its subsistence efforts.)

The fish trade was part of a market economy. Based on the records I cite the biggest purchases were for preserved fish and the fish reported in the most detail are those used to make these products. The trade records emphasize these fish in part because administrators of the fur trade such as McDougall (Jones 1999) and Henry (Gough 1992) needed to make sure their crews were fed. Accounts such as McDougall's and Henry's provide significant detail on the fish that provided the majority of their subsistence trade, but this emphasis may exclude the other fish the Indians used which were not part of the trade record.

For example, there is no discussion of the fish used to bait sturgeon lines, even though this is an important aspect of the sturgeon trade. The numbers of sturgeon taken were substantial, therefore the amount of bait used to take this fish must also have been significant. Since the bait fish were small it is likely that different kinds of nets were used to take them, yet reports on nets are limited to eulachon and salmon hoop nets and statements that seine nets were used. However, except for Swan (1973 (1857)), there is no 
information on the range of types, sizes or where they were used.

Were there other fish with usable rates of return that were simply not noted? The record of fish traded in small quantities as fresh fish (Table 4-2) is evidence that other fish were available, but with the information I have I cannot estimate their contribution to the economy of the study area.

There is a problem with the suggestion that there may be untapped fisheries. McDougall's (Jones 1999) administrative record of Fort Astoria notes periods when food was in short supply, January 1813-February 1813, so short that he put some of his staff on reduced rations and curtailed some of their expected work effort (Jones 1999:143-155). If other fish were available during periods of shortage, he would have traded for these. Therefore, I do not think it is likely that there were unreported fisheries during this period.

\section{Fish Used to Produce Preserved Food}

A month by month synopsis shows that there was not one single fish resource that dominated the economy of the study area (Table 4-1; Figure 41). That one fish did not support the economy is not surprising because, for example, the anadromous salmonids are only present during their spawning runs. Outside the periods when anadromous fish run, preserved fish or alternate fish must be targeted.

A few species and stocks of some of these species provided high rates of return, but none of these fisheries had the duration or the production to be the exclusive resource throughout the year. Sturgeon from winter and summer fisheries, eulachon, and chinook including spring, summer and fall runs provided the bulk of preserved fish (Table 4-3). Chum salmon must have played a role as a source of preserved fish, but the historic record is lacking in 
detail on its use. The information I have complied and annotated suggests that preserved spring and summer chinook was brought into the study area from outside locations, probably The Dalles and Celilo fisheries. Fall chinook was the chinook salmon stock selected for preservation in the study area.

The eulachon and white sturgeon fishery provided a substantial resource in the winter. While large quantities of preserved eulachon and sturgeon were available for trade, a question concerning the effect of the natural variability in eulachon numbers with an occasional absence from certain spawning streams, indicates a potential gap in the acquisition of resources that could not be simply filled by another fish. The winter fishery for sturgeon and eulachon seems an almost exclusive fishery with no historically identified alternatives for up to four months. Thus, the dried chinook from upriver sources and smoked cured fall chinook and chum may be critical resources if the winter fisheries for sturgeon and eulachon were not productive during any given year.

\section{Other Fish Resources}

During and in between the fisheries that provided preserved food other, species of fish were taken in smaller quantities (Table 4-2). These fish provided an alternative to fish taken in large numbers, expanding the fish resource base by five additional species.

The fish that were consumed as fresh fish included coho, steelhead, spring and summer chinook, small numbers of resident trout, and surf perch, although there is only one account of this fish in the trade. Spring and summer chinook provided a nearly continuous supply of fresh fish until the arrival of fall chinook. 
The first fish available after the winter sturgeon and eulachon fisheries and before the spring chinook fishery was salmon trout, probably steelhead. While steelhead was not used for preserved fish, it was present in sufficient numbers that it could have made a substantial contribution if stores of smoke cured sturgeon and eulachon from the winter fishery were insufficient. Commercial steelhead catches indicate that this fish was more abundant (Fulton 1970) than the historic trade record (for example Table 4-2 indicating the timing of trade) suggests.

In addition to the sturgeon fisheries that provided large returns, sturgeon provided a continuous return throughout the year of small numbers of fish (Figure 3-2). Small numbers of sturgeon were even taken during the summer chinook fishery. indicating that sturgeon was an important high rank resource, taken whenever available.

\section{Technology}

I have reported on the productivity of the fisheries as it relates to certain types of gear, but I have not discussed a suggestion raised by Grayson and Cannon (1999:146) that the value or contribution of a "resource is not intrinsic to the resource itself, but results from the interactions of resource, technology, and application of that technology". Clearly, the gear noted in the historic record, hoop net, spears, gaffs, eulachon rakes, and seine nets all took large numbers of fish. These large catches were made when fish had concentrated at spawning areas or when they were foraging on concentrated prey, or where obstructions limited or confined their movement. This suggests that gear was configured to take fish at certain places with the expectation of a large return.

There is also evidence of the replacement of gear which may have 
facilitated an increase in the number of fish caught. Lewis and Clark noted the replacement of the traditional hook with metal hooks obtained in trade. Metal hooks were also manufactured by the Indians. Steel hooks have advantages over hooks fashioned from bone. Steel hooks are more durable than bone hooks and would not have to be replaced or refurbished as frequently. Therefore, using steel hooks would reduce maintenance of gear and increased productivity of hook fisheries.

Questions concerning gear, productivity and change can be supported by information in the historic record. Fish yields obtained from using particular gear can be roughly estimated. The fisheries of the historic record provide information on the use of gear specific to certain fishing opportunities given particular environmental settings. It suggests, following Kew (1992) and Romanoff (1992), that gear was incrementally developed for different places to take fall chinook and sturgeon in a wide range of habitats.

\section{How Comprehensive is the Historic Record?}

Is the historic record a comprehensive account of the fish and fishery of the period of study? The historic sources I cite provide two kinds of records. The first are records of subsistence trade that supported EuroAmerican exploration and the fur trade. The other records are observations of Indian fishing and related activities. From these records threshold information on the abundance of fish helps to identifying fish used in trade, especially those taken in large numbers and traded as preserved fish, and some of the others that were traded more frequently.

None of the accounts were produced by trained scientists but many were inspired by the tradition of natural history. Even Wilkes (1845), whose 
staff included trained scientists, was uneven in his discussion. Although valuable information is available, the accounts lack detail. Although some fish are adequately described and the species can be stated, others lack sufficient descriptions to identify which species were taken. Even given the number of white sturgeon taken, the presence of green sturgeon cannot be ruled out. Moreover it cannot be ruled out that green sturgeon were intentionally targeted. It is hard to sort out the trade in preserved fall chinook from the trade in preserved chum salmon, although it is clear that both fish were traded.

Another matter is the degree to which a range of environmental settings are represented in the accounts I cite. For example, even though I can state that most of the fishing effort for fall chinook is in tributaries of the study area, I can only name a few streams, which are the ones that the fur company employees were invited to fish on. Moreover, most of the detailed records involve the immediate Astoria area or Oak Point. I have no information on back water sloughs and lakes or the fishing efforts that might have occurred in them. Further, I do not know whether the absence of information is because no one went there to look or the Indians did not fish in the backwaters.

\section{More Questions}

My study provides descriptive information and a synthesis of information from the historic record. My synthesis may support the analysis of some archaeological data, but more importantly it raises questions related to the fishery and fish used over time.

The demand for resources must have been greater during the prehistoric period because there were more people. The historic fish fauna and archaeological fish fauna need to be evaluated in terms of body size and 
potential productivity. In Chapter 2, I presented information on minnows and small fish frequently recovered in archaeological contexts. Aside from Franchere's mullet, there are no remarks in the historic record dealing with minnows or small fish (see also Boyd and Hajda 1987: 314). Why are small fish and minnows in the archaeological record and not in the historic record? Are they part of an incidental catch? Are they bait? How do they fit into the economy?

Butler (2000) see the presence of small fish in the prehistoric record as a sign of decline in the numbers of higher valued prey, such as the anadromous salmonids and sturgeon. The decline of these fish is attributed to the intensive fishing of a much more numerous human population that was present before contact with EuroAmericans.

Butler's suggestion that the decline in fish numbers relates to the effectiveness of fishing gear and methods raises the question involving the comparison of historic fishing gear and prehistoric fishing gear. I have shown that fishing gear used historically yielded large numbers of fish and that the gear was used in a variety of settings. However, there is little variation in some types of historic fishing gear when compared to the range of similar types found in archaeological contexts.

Swan's (1973 (1857) description of Chinook seining gear with simple notched pebble net weights does not support the stylistic variation in net gear weights reported for archaeological sites within the study area (Dunnell and Campbell 1977; Pettigrew 1977). Presumed net gear components from the archaeological record of the Portland Basin need to be evaluated and clarified by other methods rather than citing the historic record. There is only one type 
of seine net reported in the historic record, and only one type of net weight, notched pebbles.

More detailed evaluation of so-called net gear is critical for understanding the prehistoric economy in the study area and this information can only be acquired from archaeological investigations. Artifacts, such as net gauges, could provide information on the variation in ret mesh size. Knowing mesh size would help estimate the range of fish body sizes taken by nets.

If seine nets or other net configurations were used in more locations than just Baker Bay what sort of evidence would be needed to address this issue? Perhaps, the seine net fishery of the study area was simply focused on taking salmon and that was a specialty of the study area.

Another important issue is the role of a hook fishery during precontact periods. Sturgeon and trout were taken with hooks during the historic period. Metal hooks were desirable trade goods. The acute angle bone hook was at least one style of hook used in the study area before they were replaced by metal hooks (Moulton 1990).

Comprehensive studies of archaeological site in the Portland Basin and farther downstream do not report the presence hooks or even consider this kind of gear (see Pettigrew 1977; Dunnell and Campbell 1977;Minor 1983). The importance of hooks during the historic period suggest that a prehistoric hook fishery was an important method of procuring fish. Archaeological collections need to be re-examined from sites where faunal remains are present and bone tools, such as awls and needles are found. Tools identified as awl and needle fragments may exhibit shaping suggesting that they might be parts of an acute angle hook. 
Considering the fish taken in large numbers during the study period, eulachon, chinook salmon and white sturgeon, could these fish support prehistoric occupations to the same degree they supported historic ones? The scale of the fisheries discussed in the historic record supported reduced Indian populations and a robust trade with EuroAmericans engaged in the fur trade. (Although the number of people living at Fort Astoria never exceeded 100 , the post's population was mostly around 50 to 60 . These numbers are small compared to the Native American population of 1805-1830 (for example Boyd and Hajda1987:Table1). If the numbers of people present just before EuroAmerican contact was greater, then the fisheries of the precontact period must be expanded beyond the production levels hinted at by historic information.

Finally, the historic record suggests that some of the fish resources had a strategic importance. The ability to control resources is an important part of the management of resources with political implications. The Indians of the study area could and did acquire dried chinook. They were not dependent on the trade for dried chinook for preserved food because with fall chinook available, they could acquire their own stores. Thus, the study area Indians were in a good position to negotiate, they could trade for dried salmon, but if the cost was too high, they could wait until the fall chinook arrived and bargain appropriately. 


\section{REFERENCES}

Adams, P.B, C.B. Grimes, J.E. Hightower, S.T. Lindley, and M.L. Moser

2002 Status Review for North American Green Sturgeon, Acipenser medirostris. National Marine Fisheries Service, Santa Cruz, California.

Allen, M.S.

1994 Style and function in East Polynesian fish-hooks. Antiquity 70:97116.

Ames, K.M and H.D.G. Maschner

1999 Peoples of the Northwest Coast: Their Archaeology and Prehistory. Thames and Hudson, Ltd., London.

Beamesderfer, R.C., J.C. Elliott, and C.A. Foster

1989 "Report A, 1) description of the life history and population dynamics of subadult and adult white sturgeon in the Columbia River between Bonneville and McNary Dams; 2) evaluation of the need and identification of potential methods for protecting, mitigating, and enhancing white sturgeon populations in the Columbia River downstream from McNary Dam", in The Columbia River downstream from Bonneville Dam" in Status and Habitat Requirements of White Sturgeon Populations in the Columbia River Downstream from McNary Dam, Annual Progress Report April 1988-March 1989 edited by A.A.Nigro. Bonneville Power Administration, Portland.

Beamish, R.J.

1980 Adult biology of the river lamprey (Lampetra ayersi) and the Pacific lamprey (Lampetra tridentata) from the Pacific Coast of Canada. Candian Journal of Fisheries and Aquatic Sciences 48:1906-1263.

Behnke, R.J.

2002 Trout and Salmon of North America. The Free Press, New York. Bell, M.C.

1984 Fisheries Handbook of engineering requirements and biological criteria. Fish passage development and evaluation program. U. S. Army Corps of Engineers, North Pacific Division, Portland, Or.

Bettinger, R.L.

1991 Hunter-Gatherers: Archaeological and Evolutionary Theory. Plenum Press, New York.

Boyd, R.

1975 Another Look at the "Fever and Ague" of Western Oregon. Ethnohistory 22(2):135-154. 
1999 The Coming of the Spirit of Pestilence: Introduced Infectious Diseases and Population Decline Among Northwest Coast Indians, 1774-1874. University of Washington Press, Seattle.

Boyd, R. and Y. Hajda

1987 Seasonal Population Movement Along the Lower Columbia River: The Social and Ecological Context. American Ethnologist 14:309-326.

Broughton, J.M., and J.F. O'Connell

1999 On evolutionary ecology, selectionist archaeology, and

Buerge, $D$. behavioral archaeology. American Antiquity 62:153-165.

1987 The Wilkes Expedition in the Pacific Northwest. Columbia. Washington State Historical Society (1): 17-32.

Butler, V. L.

1992 Fish Remains from the Meier Site (35C05). unpublished paper.

1994 Fish feeding behavior and fish capture: the case for variation in Lapita fishing strategies. Archaeological Oceania 29:81-90.

1996 Appendix B Analysis of Fish Remains in D.V. Ellis 1996.

1998 Appendix C Analysis of Fish Remains. in D.V. Ellis 1998.

2000a Resource depression on the Northwest Coast of North America. Antiquity 74):649-61.

2000b Appendix B Faunal Remains from 35MU117 in D.V.Ellis and Erickson 2000.

2001 Letter Report to David Ellis, fish faunal remains from 35MU119 in Ellis 2001.

2004 Where have all the Native Fish Gone? The Fate of Fish That Lewis and Clark Encountered on the Lower Columbia River. Oregon Historical Quarterly Vol; 105 (3): 438-463.

Byram, S. and D.G. Lewis

2001 Ourigan: Wealth of the Northwest Coast. Oregon Historical Quarterly Vol.102(2):126-157. Oregon Historical Society, Portland.

Carl, G.C., W.A. Clemens, and C.C. Lindsey

1973 The Fresh-water Fishes of British Columbia. Queen's Printer, Victoria, British Columbia.

Close, D.A., M.S. Fitzpatrick, and H.W. Li

2002 The Ecological and Cultural Importance of a Species at Risk of Extinction, Pacific Lamprey. Fisheries Management 27:7.

Collette, $\mathrm{C}$.

1989 The Other Anadromous Fish. Northwest Energy News Northwest Planning Power Council March/April 1989 Vol. 8 (2).

Cook, S.F.

1955 The Epidemic of 1830-1833 in California and Oregon. Berkley, University of California Press. 
Cooper J. G. and G. Suckley

1859 The natural history of Washington territory, with much relating to Minnesota, Nebraska, Kansas, Oregon, and California, between the thirty-sixth and forty-ninth parallels of latitude, being those parts of the final reports on the survey of the Northern Pacific railroad route, containing the climate and physical geography, with full catalogues and descriptions of the plants and animals collected from 1853 to 1857. Balltiere Brothers, New York.

Coues, E.

1897 New Light on the early history of the greater Northwest: The Manuscript Journals of Alexander Henry and of David Thompson. 1799-1814. volume 2. Francis P. Harper, New York. Craig, J.A. and R.L. Hacker

1940 The History and Development of the Fisheries of the Columbia River. Bulletin of the Bureau of Fisheries, Volume XLIX Bulletin 32:133-215.

Croes, D. R

1997 The North-Central cultural dichotomy on the Northwest Coast of North America: its evolution as suggested by wet-site basketry Cutright, P.H. and wooden fish-hooks. Antiquity 71:594-615.

1969 Lewis and Clark: Pioneering Naturalists. Urbana, University of Illinois Press.

Davies, J.

1980 Douglas of the Forests. Seattle, University of Washington Press. Department of Fisheries and Oceans

1999 Eulachon. DFO Science Stock Status Report B6-06. Nanaimo, British Columbia.

DeVore, J.D., B.W. James, C.A. Tracy and D.A. Hale

1995 Dynamics and Potential Production of White Sturgeon in the Unimpounded Lower Columbia River. Transactions of the American Fisheries Society. 124:845-856.

DeVore, J., B. James and R. Beamesderfer

1999 Lower Columbia River White Sturgeon Current Stock Status and Management Implications. Draft Washington department of Fish and Wildlife and Oregon Department of Fish and Wildlife.

Donaldson, I. J. and F.K. Cramer

1971 Fishwheels on the Columbia. Binfords and Mort, Portland. Drucker, $P$.

1963 Indians of the Northwest Coast. Natural History Press, Garden City.

Dunnell, R.C. and C. Beck

1979 The Caples Site, 45-SA-5, Skamania County, Washington, 
University of Washington. Department of Anthropology. Seattle.

Dunnell, R.C. and S. Campbell

1977 History of Aboriginal Occupation of Hamilton Island,

Washington. University of Washington Reports in Anthropology

4. University of Washington, Department of Anthropology, Seattle.

Elllis, D.V. and S.W. Horton

1998 Cultural Resource Investigations for the LSI Logic Phase III

Gresham Wastewater Treatment Plant Outfall, Fairview, Oregon.

Report Prepared for Black and Veatch, Lake Oswego, Oregon.

copy on file Portland District, U. S. Army Corps of Engineers.

Emmett, R.L., S.A.Hinton, S.L. Stone and M.E. Monaco

1991 Distribution and abundance of fishes and invertebrates in west

coast estuaries, Vol II: Species life history summaries. ELMR

Rep No. 8. NOAA/NOS Strategic Environmental Assessment

Division, Rockville, MD.

"EPIC" Environmental Protection Information Center, Center for Biological

Diversity and Waterkeepers Northern California (Petitioners)

2001 Petition to List The North American Green Sturgeon (Acipenser

medirostris) As an Endangered or Threaten Species Under the

Endangered Species Act; Petition to the National Marine

Fisheries Service.

Eschmeyer, W.N. and E.S. Herald

1983 A. Field Guide to Pacific Coast Fishes of North America. Peterson

Field Guides. Houghton Mifflin Co., Boston:

Farr, R.A. and T.A. Rein

2002 Annual Progress report Fish Research Project in Oregon: Green

Sturgeon population Characteristics in Oregon. Appendix B A

Catch Rate Index for Green Sturgeon Harvested in Lower

Columbia River Commercial Fisheries. Project Number F-178-

$\mathrm{R}, 1$-October-30 September 2002. Oregon Department of Fish

and Wildlife, Clackamas, Or.

Farr, R.A. and D.L.Ward

1993 Fishes of the Lower Willamette River, Near Portland, Oregon. Northwest Science 67 (1):16-22.

Franchere, G.

1967 Adventure at Astoria, 1810-1814. Edited and translated by Hoyt

C. Franchere. University of Oklahoma Press, Norman.

1969 Journal of a Voyage on the North West Coast of North America

during the Years 1811, 1812, 1813 and 1814. translated and edited by Lamb, W.T and W.K. Lamb. The Champlain Society, Toronto.

Fulton, L.A.

1968 Spawning Areas and Abundance of Chinook Salmon

(Oncorhynchus tshawytscha) in The Columbia River Basin-Past 
and Present. U. S. Fish and Wildlife Service Special Scientific Report-Fisheries No. 571. Washington, D.C.

1970 Spawning Areas and Abundance of Steelhead Trout and Coho, Sockeye, and Chum Salmon in the Columbia River Basin-Past and Present. U. S. Fish and Wildlife Service Special Scientific Report-Fisheries No. 618. Washington, D.C.

Gadomski, D.M., C.A. Barfoot, J.M.Bayer, and T.P. Poe

2001 Early Life History of the Northern Pikeminnow in the Lower Columbia Basin. Transactions of the American Fisheries Society. 130: $250-262$.

Galbreath, J.

1979 Columbia River colossus, the white sturgeon. Oregon Wildlife, March.

Gough, B.M.

1992 The Journal of Alexander Henry the Younger 1799-1814, Vol. I Red River and the Journey to the Missouri and Vol. 2 The Saskatchewan and Columbia Rivers. The Champlain Society, Toronto.

Grayson, D.K. and M.D. Cannon

1999 Human Paleoecology and Foraging in the Great Basin. in Models for the Millennium Great Basin Anthropology Today edited by C. Beck. University of Utah Press, Salt Lake City.

Hajda, Y.P

1984 Regional Social Organization in the Greater Lower Columbia 1792-1830. Ph.D dissertation, University of Washington, Seattle, University Microfilms, Ann Arbor.

1990 Southwestern Coast Salish. In Northwest Coast edited by W. Suttles, pp. 533-546 Handbook of North American Indians, vol.

(7) W.C. Sturtevant, general editor, Smithsonian Institution, Washington, D.C.

Haynes, J.M., R.H.G, and J.C. Montgomery

1978 Seasonal Movements of White Sturgeon (Acipenser

transmontanus) in the Mid-Columbia River. in Transactions of the American Fisheries Society 107(2):275-280.

Haynes, J.M. and R.H. Gray.

1981 Diel and Seasonal movement of White Sturgeon Acipenser transmontanus. In The mid-Columbia River. Fishery Bulletin 79:367-370.

Hinrichsen, R.A.

1998 The Ghost Run of the Cowlitz. Cowlitz Historical Quarterly 40(2):5-21.

Hinton, S.A., G.T. McCabe, Jr., and R. L. Emmett.

1990. Fishes, benthic invertebrates, and sediment characteristics in intertidal and subtidal habitats at five areas in the Columbia 
River estuary. Report to U. S. Army Corps of Engineers, Portland District, Portland, Or.

Hinton, S. and R.L. Emmett

2000 Biological Surveys of the Trestle Bay Enhancement Project 1994, 1996-97, NOAA Technical Memorandum NMFS-NWFS-39.

Howay, F.W.

1941 Voyages of the "Columbia" to the Northwest Coast 1787-1790 and 1790-1793. John Boit's Log of the Second Voyage of the Columbia. Da Capo Press, New York.

Hunn, E.

1990 Nch'i-Wana "The Big River" Mid-Columbia Indians and Their Lands. University of Washington Press, Seattle.

Johnson, S. and P. Fishman

1996 Studies of Dredged Material Rehandling Sites; Channel Deepening Feasibility Study-Fish Sampling Report. Prepared for the Port of Portland and U. S. Army Corps of Engineers, Portland District. Fishman Environmental Services, Portland.

Jones, R.F. (ed,)

1999 Annals of Astoria: The Headquarters Log of the Pacific Fur Company on the Columbia River, 1811-1813. Fordham University Press, New York.

Kew, M.

1992 Salmon Availability, Technology, and Cultural Adaptation in the Fraser River Watershed. In a Complex Culture of the British Columbia Plateau: Traditional Stl'tlimx Resource Use; B. Hayden, ed. pp. 177-221.University of British Columbia, Vancouver.

Krauss, M.E.

1990 Kwalhioqua and Clatskanie. In Northwest Coast edited by W. Suttles, pp. 530-532 Handbook of North American Indians, vol. (7) W.C. Sturtevant, general editor, Smithsonian Institution, Washington, D.C.

Lamb, A. and P. Edgell

1986 Coastal fishes of the Pacific Northwest. Harbour Publishing Co. Ltd., BC, Canada.

Lassuy, D.R. and D. Moran

1989 Species Profiles: Life Histories and Environmental requirements of Coastal Fishes and Invertebrates (Pacific Northwest)-Pacific Herring: U. S. Fish Wildlife Service Biological report 82(11.126). U. S. Army Corps of Engineers, TR-EL-82-4.

Laufle, J.C., G.B. Pauley and M.F. Shepard

1986 Species Profiles: Life Histories and Environmental Requirements of Coastal Fishes and Invertebrates (Pacific Northwest) Coho 
Leonard, L.

Salmon. U. S. Fish Wildlife. Service. Biol. Rep 82(11.48). U. S. Army Corps of Engineers.

1987 Sturgeon Fishing. Portland, Frank Amato Publications.

Lyman, R.L. and M.J. O'Brien

1998 The Goals of Evolutionary Archaeology History and Explanation. Current Anthropology 39(5):615-651.

Manitoba

2006 www.gov.mb.ca/conservation/sustain/nut.html. "Nutrient content of some species of Manitoba fish'. visited site on 1/30/06

Martin, I.

1994 Legacy and Testament: The Story of Columbia River Gillnetters. Pullman, Washington State University Press.

Matson, R.G.

1992 The Evolution of Northwest Coast Subsistence. In Long-term Subsistence Change Change in Prehistoric North America, D.F. Croes, R.A. Hawkins, and B.I. Isaac, eds. Research In Economic Anthropology Supplement 6: 367-428.

Matson. R.G and G. Coupland

1995 The Prehistory of the Northwest Coast. Academic Press. Orlando. Mattson, C.R.

1949 Lamprey Fishery at Willamette Falls. Fish Commission Research Briefs. Fish Commission of Oregon volume 2 No. 2: Portland.

McCabe, G.T., S.A. Hinton and R.J.M. Connell

1989 Report D; Description of reproduction and early life history characteristics of white sturgeon populations in the Columbia River downstream from Bonneville Dam [and] 2) Definition of habitat requirements for spawning and rearing of white sturgeon and quantification of extent of habitat available in the Columbia River downstream of Bonneville Dam in Status and Habitat Requirements of White Sturgeon Populations in the Columbia River Downstream from McNary Dam Annual Report 1989 edited by F. Holm. Bonneville Power Administration, Portland.

McCabe, G.T. Jr., and C.A. Tracy

1994 Spawning and early life history of white sturgeon, Acipenser transmontanus in the lower Columbia River. Fisheries Bulletin 92:760-772.

McCrae, J.

1994 Oregon Developmental Species Pacific Herring Clupea pallasi. Oregon Department of Fish and Wildlife.

Michael, J.H.

1984 Additional notes on the repeat spawning by Pacific Lamprey.

California Fish and Game 75:188-88. 
Michigan.gov

2006 http://www.michigan.gov/dnr/0,1607,7-153-10364_18958-45693-

Minor, R.

00.html; visited site on 1/28/06

1983 Aboriginal Settlement and Subsistence at the Mouth of the Columbia River. Unpublished Ph.D. Dissertation. Department of Anthropology, University of Oregon.

Mitchell, D. and L. Donald

1988 Archaeology and the Study of Northwest Economies. Prehistoric Economies of the Northwest Coast, Supplement No. 3, Research in Economic Anthropology, pp 293-351, JAI Press, Greenwich.

Monaco, M.E., R.L. Emmett, D.M. Nelson and S.A. Hinton

1990 Distribution and abundance of Fishes and Invertebrates in West Coast Estuaries Volume II: Species Life History Summaries Volume I: Data Summaries. ELMR Rep No.4 NOAA/NOS Strategic Environmental Assessments Division, Silver Springs, MD.

Monks, G.G.

1987 Prey as Bait: the Deep Bay Example. Canadian Journal of Archaeology, 11: 119-140.

Moulton, G.E.

1990 The Journals of Lewis and Clark Expedition, vol. 6 November 2, 1805-March 22, 1806. University of Nebraska Press, Lincoln.

1991 The Journals of Lewis and Clark Expedition, vol. 7 March 23June 9 1806. University of Nebraska Press, Lincoln.

1995 The Journals of Lewis and Clark Expedition, The Journals of John Ordway May 14, 1804-September 23, 1806, and Charles Floyd, May 14-August 18, 1804. University of Nebraska Press, Lincoln.

1996 The Journals of Lewis and Clark Expedition, The Journal of Patrick Gass May 14, 1804-September 23, 1806. University of Nebraska Press, Lincoln.

Moyle, P.B.

1976 Inland fishes of California. University of California Press, Berkeley

Mullan, J.W., M.B. Dell, S.G. Hays, and J.A. McGee

ca. 1984 Interpretation of Dam Counts of Resident Fishes in the Columbia Basin, 1934-1983. contracted report, U. S. Army Corps of Engineers, Portland District. (draft) National Marine Fisheries Service.

1977 Anglers' Guide To The United States Pacific Coast. National Technical Service. U. S. Department of Commerce, Springfield, Virginia. 
Netboy, A.

1980 The Columbia River Salmon and Steelhead trout: Their Fight for Survival. University of Washington Press, Seattle.

Orcutt, H.G.

1950 The life history of the starry flounder, Platichthys stellatus (Pallas). California Fish and Game, Fishery Bulletin 78:1-64.

Parsley, M.J., S. Duke, T.J. Underwood and L.G. Beckman

1989 Report C. in Status and Habitat requirements of White Sturgeon Populations in the Columbia River Downstream from McNary Dam ed. A. Nigro. Prepared for Bonneville Power Administration, Portland, Or.

Parsley, M.J., L.G. Beckman and G.T. Beckman

1993 Spawning and Rearing Habitat Use by White Sturgeons in the Columbia River Downstream from McNary Dam. in Transactions of the American Fisheries Society, 122:217-227.

Parsley, M.J., N.D. Popoff and J.R. Hatten

2004 Demystifying sturgeon-remote telemetry provides insight into the daily life of white sturgeon in the lower Columbia River. Paper given at the OCAFS 2004 Annual meeting, Sun River, Oregon.

Parsley, M.J. and N.D. Popoff

2004 Site Fidelity, Habitat Associations and Behavior During dredging Operations of White Sturgeon at Three Tree Point in the Lower. Columbia River. Final report to the U. S. Army Corps of Engineers, Portland District, Portland, Oregon, U.S. Geological Survey, Western Fisheries Research Center, Cook, Washington.

Patten, B.G. and D.T. Rodman

1969 Reproductive behavior of northern squawfish. Ptychoheilus oregonensis. Transactions of American Fisheries Society. 98:108-111.

Pettigrew, $\mathrm{R}$.

1977 A Prehistoric cultural sequence in the Portland Basin of the Lower Columbia Valley, Ph.D. dissertation, University of Oregon, Department of Anthropology.

1990 Prehistory of the Lower Columbia and Willamette Valley. In Northwest Coast edited by W. Suttles, pp. 518-529 Handbook of North American Indians, vol. (7) W.C. Sturtevant, general editor, Smithsonian Institution, Washington, D.C.

Portland District, U.S. Army Corps of Engineers

2005 www.nwp.usace.army.mil/op/fishdata/fcounts.asp; visited site on $11 / 28 / 2005$

Ramano M. and Rien, T.

2001 Columbia River White Sturgeon Monitoring Study. Draft annual progress report to U. S. Army Corps of Engineers. Oregon Department of Fish and Wildlife, Clackamas, Oregon. 
Ray, V.

1938 Lower Chinook Ethnographic Notes. University of Washington Publications in Anthropology. 7(2):29-165. Seattle.

Reimchen, T.E.

1994 Predators and morphological evolution in threespine stickleback. In The Evolutionary Biology of the Threespine Stickleback edited by M.A. Bell and S.A. Foster, Oxford University Press, Oxford.

Ricklefs, R.E.

1973 Ecology. Chiron Press. Portland.

Rollins, P.A.

1995 The Discovery of the Oregon Trail, Robert Stuart's Narratives of his overland trip eastward from Astoria in 1812-1813. (reprint of the 1935 edition) edited by P.A. Rollins with an introduction by $\mathrm{H}$.

Romanoff, S. Lamar. University of Nebraska Press, Lincoln.

1992 Stl'atl'imx (Fraser River Lillooet Fishing). in A Complex Culture of the British Columbia Plateau edited by B. Hayden, 266-354. University of British Columbia Press, Vancouver, British Columbia.

Ronda, J.P.

1990 Astoria and the Empire. University of Nebraska Press, Lincoln. Saleeby, B.

1983 Prehistoric Settlement Patterns in the Portland Basin of the Lower Columbia River: Ethnohistoric, Archaeological, and Biographic Perspectives. Ph.D. dissertation, University of Oregon, Department of Anthropology.

Saleeby, B. and R. Pettigrew.

1983 Seasonality of Occupation of Ethnohistorically Documented Villages of the Lower Columbia River. In Prehistoric Places on the Southern Northwest Coast edited by R.E. Greengo, pp. 169193. Thomas Burke Memorial Washington State Museum, University of Washington, Seattle.

Schalk, R.

1977 The Structure of an Anadromous Fish Resource. In For Theory Building in Archaeology, edited by L.B. Binford, pp.207-249. Academic Press, New York.

1984 The Columbia Plateau salmon fisheries: Archaeological Evidence for Intensification. Paper Present at the 49th Annual Meeting of the Society for American Archaeology. Portland, Oregon.

1986 Estimating Salmon and Steelhead Usage in the Columbia Basin before 1850: The Anthropological Perspective. Northwest Environmental Journal 2(2): 1-30. 
Scott, W. B. and E.J Crossman.

1973 Freshwater fishes of Canada. Fisheries Research Board of Canada. Bulletin. Ontario.

Silverstein, $M$.

1990 Chinookans of the Lower Columbia. In Northwest Coast edited by W. Suttles, pp. 533-546 Handbook of North American Indians, vol. (7) W.C.Sturtevant, general editor, Smithsonian Institution, Washington, D.C.

Smith, W.E. and R.W. Saalfeld

1955 Studies on Columbia River Smelt, Thaleichthys Pacificus. (Richardson). Washington Department of Fish, Fisheries Research Papers 1(3):3-26.

Smith, H.M.

1895 Notes on the Reconnaissance of the fisheries of the Pacific coast of the United States in 1894. U. S. Fish Commission, Bulletin, vol XV: 223-288.(cited by Craig and Hacker (1940).

Stewart, $\mathrm{H}$.

1977 Indian Fishing Early Methods on the Northwest Coast.

University of Washington Press, Seattle.

Suttles, W.

1968 Coping with Abundance: Subsistence on the Northwest Coast. In Man the Hunter, edited by R.B. Lee and I. DevoreAldine Publishing Company, Chicago.

1990 Environment in Handbook of North American Indians, Northwest Coast (7)16-29. ed. by W. Suttles, Smithsonian Institution, Washington, D.C. 1990 (editor) Handbook of North American Indians, Northwest Coast. Smithsonian Institution, Washington, D.C.

Swan, J.G.

1973 (1857) The Northwest Coast or Three Years in Residence in Washington Territory. Harper and Row, Seattle.

Thwaites, R.G.

1966 (1905) Narrative of a Journey across the Rocky Mountains to the Columbia River, and a visit to the Sandwich Islands, Chili and C. A.H.Clark Co., Cleveland.

1969 Original Journals of the Lewis and Clark Expedition 1804-1806. reprint of the 1905 edition. Arno Press, New York. Townsend, J.K.

1978 Narrative of a Journey across the Rocky Mountains to the Columbia River. Donald Jackson (reprint of Thwaites, R.G. 1905 from Townsend's 1836 edition) University of Nebraska Press, Lincoln.

Vancouver, G.

1926 (1792) The Exploration of the Columbia River by Lieutenant W.R. 
Broughton, October 1792 An Extract from the Journal of Captain George Vancouver. reprint Press of the Longview daily News, Long View Washington. Davis \& Holman, Portland.

Vaughan, T., C. Campbell, L. Flannery, B. Hamilton, P. Knuth, L. Lesowski, J. Mouser and E. Winroth.

1980 Columbia's Gateway: A History of the Columbia River Estuary to 1920. Pacific Northwest River Basins Commission.

Viola, $H$. and C. Margolis (Ed.)

1985. Magnificent Voyagers: The U. S. Exploring Expedition 18381842. The Smithsonian Institution Press, Washington, D.C.

Warner, G. and I. Warner

1975 Trojan III, 35C01, Oregon Archaeological Society, report No. 7. Portland.

Washington, P.M.

1970 Occurrence on the high seas of a steelhead trout in its ninth year. California Fish and Game 56 (4): 312-314.

Washington Department of Fish and Wildlife

2006 Columbia River Sockeye, http://wdfw.wa.gov/fish/sockeye/columbia.htm. visited site 3/23/06.

West, $T$.

2002 Northern Pikeminnow (Ptychocheilus oregonensis) Population Reduction Program Rocky Reach Dam and Rock Island Dam. Public Utility District No. 1 of Chelan County Wenatchee, Washington.

Wilks, W.

1959 Journal Kept by David Douglas During his Travels in North America 1823-1827 Together with a Particular Description of Thirty-Three Species of American Oaks and Eighteen Species of Pinus. Antiquarian Press, New York.

Wilkes, C.

1845 Narrative of the United States Exploring Expedition during the Years 1838, 1840,1842. 5 vols, Philadelphia.

Winterhalder, B.

1981 Optimal Foraging Strategies and Hunter-Gather Research in Anthropology: Theory and Models. In Hunter-Gather Foraging Strategies: Ethnographic and Archeological Analysis, 13-35. edited by B. Winterhalder and E.A. Smith. University of Chicago Press, Chicago.

Wydoski, R.S. and R.R. Whitney

1979 Inland Fishes of Washington. First edition. University of Washington Press, Seattle.

2003 Inland Fishes of Washington. Second edition. University of Washington Press, Seattle. 